Beata Maria Nowak

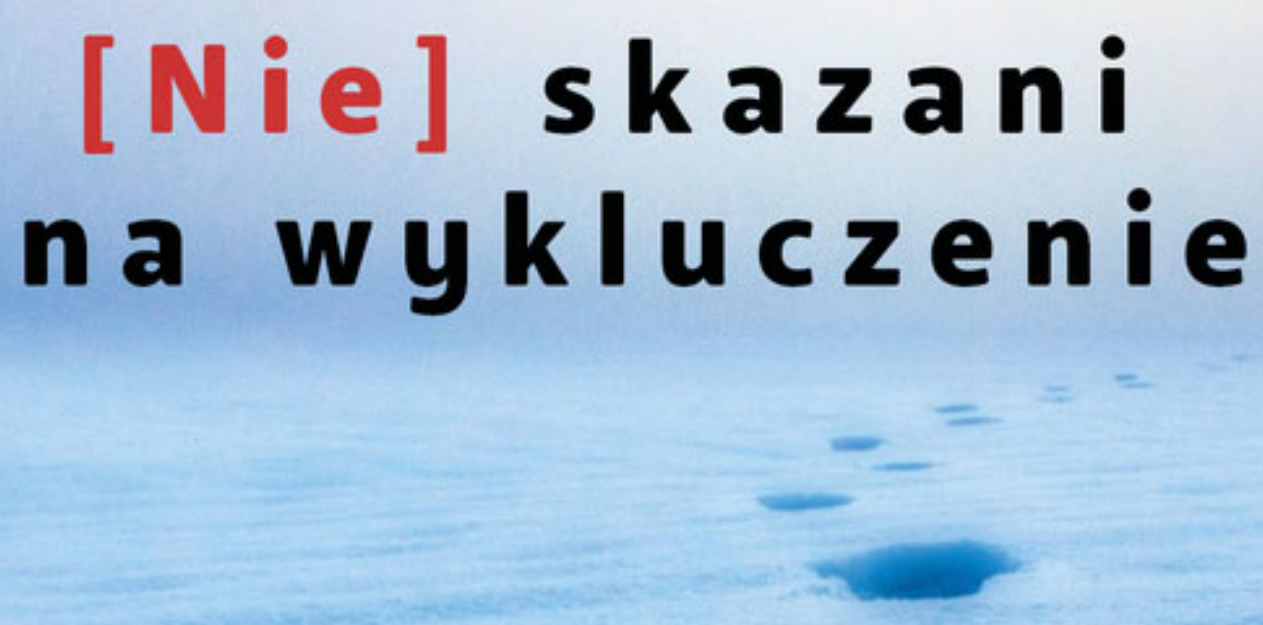

Od patologii do normy zachowań społecznych 


\section{(Nie)skazani na wykluczenie Od patologii do normy zachowań społecznych}



Beata Maria Nowak

\section{(Nie)skazani na wykluczenie \\ Od patologii do normy zachowań społecznych}
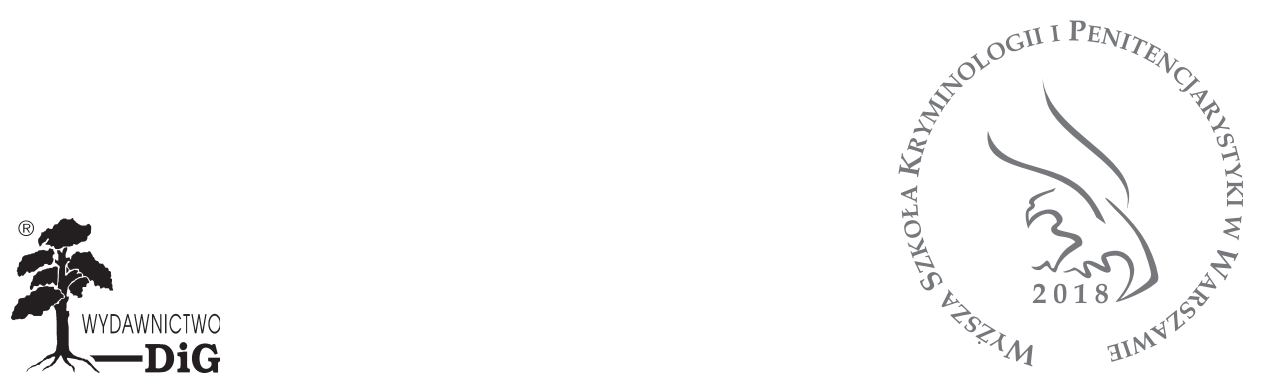
Recenzenci:

$d r$ hab. Krystyna Ostrowska, profesor Wyższej Szkoty Menedżerskiej w Warszawie dr hab. Irena Mudrecka, profesor Uniwersytetu Opolskiego

$d r$ hab. Krzysztof A. Wojcieszek, profesor Wyższej Szkoty Kryminologii i Penitencjarystyki w Warszawie

Projekt okładki:

Aleksander Nowak

Konrad Wierzbicki

Opracowanie redakcyjne:

Dorota Kanabus

Skład:

Mercurius

(C) Copyright by Wydawnictwo DiG, 2020

ISBN DiG: 978-83-286-0147-5

ISBN WSKiP: 978-83-66454-13-2

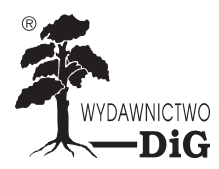

Wydawnictwo DiG Sp. j.

PL 01-987 Warszawa, ul. Dankowicka 16c lok. 2

tel./fax: (+48 22) 8390838

e-mail: biuro@dig.pl,http://www.dig.pl

Druk cyfrowy 


\section{Spis treści}

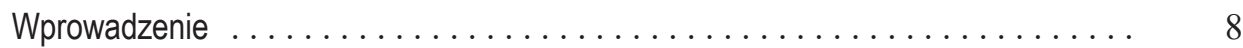

\section{Część I \\ Zachowania przestępcze — od normy do patologii}

1.1. Przestępczość i recydywa jako zjawiska patologiczne ........... 19

1.2. Wybrane ścieżki angażowania się w przestępczość $\ldots \ldots \ldots \ldots \ldots 23$

1.3. Teoria stylu życia Glenna D. Waltersa $\ldots \ldots \ldots \ldots \ldots \ldots \ldots \ldots .30$

1.4. Rola przestępcy w perspektywie interakcyjnej i transakcyjnej $\ldots . . . \quad 38$

1.5. Konflikt i negocjacje w teorii światów społecznych Anselma Straussa . . $\quad 40$

\section{Część II}

Ocena przyczyn powrotności do przestępstwa — uwikłania interpretacyjne

2.1. Wyjaśnianie przyczyn zdarzeń - przegląd wybranych koncepcji

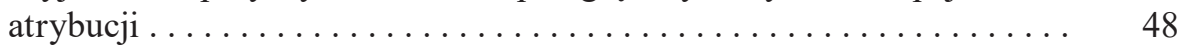

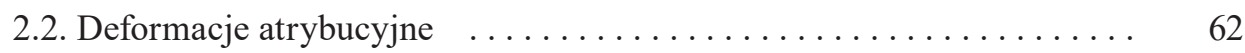

2.3. Etykiety i stereotypy w procesie przetwarzania informacji i formowania

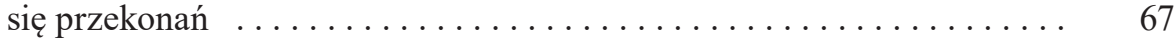

2.4. Rola pamięci autobiograficznej w procesie adaptacji społecznej i psychologicznej . ............................ $\quad 70$

\section{Część III \\ Porażka readaptacyjna w narracji recydywistów penitencjarnych \\ (badania własne)}

3.1. Izolacja więzienna i jej skutki $\ldots \ldots \ldots \ldots \ldots \ldots \ldots \ldots \ldots \ldots \ldots$

3.2. Ograniczenia i upośledzenia świata wewnętrznego osób skazanych .... 85

3.3. Społeczno-środowiskowy „kosmos” niesprawności i niemocy powrotnych ................................... 104

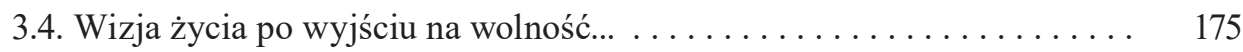




\section{Cześć IV \\ Reintegracja społeczna — od patologii do normy zachowań społecznych}

4.1. Iluzja reintegracyjna: kalejdoskop (nie)skuteczności systemowych $\ldots . \quad 185$

4.2. Wspomaganie reintegracyjne ekswięźniów w ujęciu sieciowosystemowym .............................. 191

4.3. Modele wspomagania reintegracyjnego ekswięźniów i ich rodzin .... 199

Nadzieja na lepsze jutro - zamiast zakończenia f............. 207

Bibliografia ..................................... 209 
Bądź wdzięczny za trudne chwile. One pozwalaja ci się rozwijać. Bądź wdzięczny za swoje ograniczenia, ponieważ one daja ci szansę na poprawę. Bądź wdzięczny za każde nowe wyzwanie, ponieważ ono buduje twoja sitę i charakter. Bądź wdzięczny za swoje błędy. Przekazuja Ci cenne lekcje.

[Troy Amdahl]

\section{Moim Rodzicom poświęcam}




\section{Wprowadzenie}

Zasadniczym celem kary pozbawienia wolności jest poprawa moralna osoby skazanej, wiążąca się z radykalnymi przeobrażeniami jej osobowości, skutkującymi zmianą regulacji stosunków z otoczeniem i zwiększającymi szanse na pozytywną readaptację i reintegrację społeczną. Osiągnięcie tego celu maksimum warunkowane jest między innymi podejmowaniem oddziaływań prowadzących do wzbudzenia pozytywnej motywacji i zaangażowania osadzonych w proces zmian wewnętrznych.

Ścieżka poprawy moralnej rozpoczyna się wprawdzie w miejscu osadzenia, ale wyżej zdefiniowana aktywność wymaga uwzględnienia jej trzech istotnych atrybutów: kontekstu społecznego, intencjonalności (działania na podstawie subiektywnie określonych celów, oczekiwań i efektów) oraz antropomorficzności - zdolności do świadomego stosowania reguł oraz realizowania założonych planów i strategii ukierunkowanych na osiąganie pożądanych efektów. W warunkach izolacyjnych jest to wymóg trudny do spełnienia, chociażby z uwagi na z góry określony i sztywny kontekst społeczny uniemożliwiający realizację procesu uspołecznienia oraz negatywne skutki długotrwałej izolacji więziennej, zaburzające proces pożądanych transformacji osobowościowych. Oddziaływania penitencjarne jawią się zatem jako faza wstępna procesów resocjalizacji i readaptacji społecznej, które po zakończeniu kary izolacji powinny być realizowane w naturalnym środowisku życia skazanych i zakończone ich pełną reintegracją społeczną. Do pozytywnej i trwałej reintegracji społecznej prowadzą bowiem nie tylko intencjonalne działania (re)edukacyjne mające na celu opanowanie i ugruntowanie przez skazanych konkretnych kompetencji życiowych, w tym społecznych i zawodowych, ale również sieci konstruktywnego wsparcia społecznego, ukierunkowane na budowanie silnych więzi międzyludzkich, zaspokajających większość podstawowych potrzeb człowieka: akceptacji, poczucia bezpieczeństwa, afiliacji czy szacunku.

Podstawowe i kluczowe zarazem staje się pytanie nie tylko o wizerunek ekswięźnia, o jego wewnętrzne potencjały readaptacyjne (kompetencje życiowe, system wartości czy relacje z rodziną), ale także o jego zewnętrzne możliwości reintegracyjne: Czy funkcjonuje on w poprzednim środowisku życia, tym sprzed osadzenia? A może tuła się w poszukiwaniu nowego miejsca? Czy funkcjonuje w sposób prawidłowy? Co wskazuje na to, że jest na nowo zaadaptowany i zintegrowany ze społeczeństwem? Odpowiedź na te pytania, wybrane 
z całego spektrum poważnych problemów - wyzwań dotyczących problematyki poruszanej w niniejszym opracowaniu, nie jest prosta i wymaga głębokich, interdyscyplinarnych rozważań teoretycznych oraz gruntownej, wieloczynnikowej analizy danych empirycznych pozyskanych z wieloaspektowych badań naukowych.

Książka nie aspiruje do opracowania kompleksowego. Prezentuje bowiem brakującą składową w myśleniu o readaptacji i reintegracji społecznej ekswięźniów, czyli perspektywę skazanych. Mam nadzieję, że stanie się ona impulsem do podjęcia kolejnych refleksji naukowych oraz inspiracją dla badaczy zajmujących się przedmiotową problematyką, a zwłaszcza tych, którzy poszukują odpowiedzi na podstawowy problem: W jaki sposób należy zmodernizować współczesny system profilaktyki i resocjalizacji, by reintegracja społeczna skazanych stała się faktem dokonanym? Głębokie penetracje literatury przedmiotu, wyniki badań prezentowanych $\mathrm{w}$ niniejszym opracowaniu oraz we wcześniejszych publikacjach, ugruntowały moje przeświadczenie, że jest to zasadnicze pytanie o ścieżki resocjalizacyjno-readaptacyjne prowadzące skazanych do sukcesu reintegracyjnego.

Poszukując odpowiedzi na pytania o niesprawność systemową i fiasko readaptacyjne doświadczane przez gros byłych skazanych, w latach 2015-2019 zrealizowałam wieloaspektowe badania nad przyczynami porażki reintegracyjnej ekswięźniów. Głównym ich celem była próba rozpoznania przyczyn niepowodzenia reintegracyjnego i powrotności ekswięźniów do przestępstwa. Adekwatnie do tak postawionego celu poszukiwałam odpowiedzi na główne problemy badawcze sformułowane w postaci pytań: Jakie są najczęstsze przyczyny niepowodzenia reintegracyjnego ekswięźniów w ocenie badanych recydywistów? W jaki sposób badani recydywiści interpretują własną porażkę readaptacyjną i powrotność do przestępstwa? Badania nad porażką reintegracyjną doświadczaną przez recydywistów penitencjarnych i ocenianą przez nich samych ukierunkowane zostały zatem na identyfikację przyczyn powrotności do przestępstwa, postrzeganych przez pryzmat odniesień recydywistów do własnego sprawstwa, do więzi i relacji rodzinnych, społecznościowych oraz środowiskowej pomocy i wsparcia reintegracyjnego.

$\mathrm{Na}$ etapie projektowania schematu badawczego zastanawiałam się nad zastosowaniem różnych paradygmatów badawczych, modeli oraz podejść strategicznych optymalnych $\mathrm{w}$ odniesieniu do podjętego zagadnienia, biorąc przy tym pod uwagę realne możliwości oraz ograniczenia w jego eksplorowaniu. W celu dokonania rozstrzygnięć metodologicznych przeanalizowałam na wstępie dwie podstawowe klasyfikacje paradygmatów badawczych, stosowane współcześnie w praktyce badań edukacyjnych.

Pierwszą jest klasyfikacja autorstwa Gibsona Burrella i Garetha Morgana, która obejmuje dwa wymiary. Jeden jest wypadkową obiektywnej i subiektywnej epistemologii badanych zjawisk, zaś drugi stanowi rezultat regulacji i radykalnej zmiany (fundamentalnych cech społeczeństwa). Pozwoliło to na 
wyłonienie czterech podstawowych paradygmatów: radykalnego humanizmu $\mathrm{i}$ interpretatywizmu wyrastającego $\mathrm{z}$ wymiaru subiektywnego oraz radykalnego strukturalizmu i funkcjonalizmu związanego z wymiarem obiektywnym. Druga klasyfikacja, autorstwa Egona Guby i Yvonny Lincoln, została opracowana na założeniach ontologicznych (realizm i relatywizm), epistemologicznych (obiektywizm i subiektywizm) oraz metodologicznych. Na tej podstawie wyróżniono pięć paradygmatów: pozytywizm, postpozytywizm, teoria krytyczna, konstruktywizm oraz uczestnictwo [za: Cupryjak 2016].

W modelu pozytywistycznym bazującym na wyjaśnianiu prawidłowości, dotarcie do wiedzy obiektywnej i materialnej wymaga od badacza wejścia w rolę obserwatora. Przyjęcie tej opcji metodologicznej wiąże się z zastosowaniem podejścia nomotetycznego [Rubacha 2008]. Kluczowym pojęciem w paradygmacie normatywnym jest zachowanie powiązane $\mathrm{z}$ reakcją jednostki na bodźce środowiska zewnętrznego (np. odniesienia do norm społecznych) lub na bodźce wewnętrzne zaistniałe w przeszłości (np. dążenie do osiągnięcia wyznaczonego celu). Założenia paradygmatu normatywnego wskazują po pierwsze, że zachowanie człowieka jest zależne od zasad i po drugie, że metody do jego pomiaru powinny być osadzone w naukach przyrodniczych, stąd jest mu przypisana strategia ilościowa [Douglas 1973].

Dla modelu konstruktywistycznego typowe jest natomiast podejście idiograficzne, związane z dążeniem do zrozumienia indywidualnych zachowań oraz poszukiwania cech niepowtarzalnych i jednostkowych. Paradygmat interpretatywny skoncentrowany jest zatem na wyjaśnianiu kontekstu. Eksponuje subiektywne doświadczenie jednostek, biorąc pod uwagę rzeczywistość społeczną zmienną i kreowaną przez człowieka. Model konstruktywistyczny i związane z nim strategie jakościowe o cechach wyjaśnień idiograficznych wymagają od badacza głębokiej wiedzy przedmiotowej oraz postrzegania jej jako osobistej i subiektywnej. Badanie w ramach tego modelu jest ukierunkowane na identyfikację unikatowych cech jednostkowych. Jest intencjonalne i prowadzone w celu zrozumienia interpretacji otaczającego świata przez badany podmiot. W trosce o zachowanie podejścia idiomatycznego konieczne staje się zaprojektowanie takiego toku postępowania badawczego, by był on adekwatnie dopasowany do identyfikowanego idiomu przedmiotu badań i jego kontekstów [Kubinowski 2017]. Jednakże należy podkreślić, że

badanie jakościowe jest trudna sztuka improwizacji i dlatego nie może zostać poddane ścistej formalizacji metodologicznej. Jego metodyka jest z jednej strony oparta na konkretnych zasadach określajacych dopuszczalne sposoby myślenia o regułach procesu poznawczego, które tworza ogólne podstawy konstruowania adekwatnych rozwiąań metodologicznych każdorazowo wynikajacych ze specyfiki danego projektu badawczego, a z drugiej — obejmuje obszerny i stale powiększający się zbiór konkretnych tradycji, koncepcji i podejść badawczych zastosowanych z powodzeniem 
przez poszczególnych badaczy w poszukiwaniu odpowiedzi na formułowane przez nich lub wyłaniające się problemy [Kubinowski 2010, s. 159].

Przegląd literatury przedmiotu wskazuje na niedostatek opracowań oraz projektów naukowo-badawczych realizowanych w paradygmacie komplementarnym. Biorąc to pod uwagę oraz przyjmując klasyfikację E. Guby i Y. Lincoln, omawiany projekt badawczy zaprojektowano w taki sposób, by eksploracje empiryczne prowadzone były w ramach uzupełniających się modeli: pozytywistycznego (paradygmat normatywny, podejście nomotetyczne, strategia ilościowa) oraz konstruktywistycznego (paradygmat interpretatywny, podejście idiograficzne, strategia jakościowa).

Badania nad porażką readaptacyjną ekswięźniów były wieloetapowe. $\mathrm{Na}$ pierwszym etapie skoncentrowano się na badaniu ankietowym, w którym uczestniczyło 245 recydywistów osadzonych w wytypowanych zakładach karnych, w tym 137 jednokrotnych i 108 wielokrotnych. W ramach drugiego etapu przeprowadzono wywiady narracyjne (w formie bezpośredniej i pisemnej) z kolejnymi 425 osadzonymi recydywistami, zaś na trzecim etapie poddano badaniu w warunkach wolnościowych 30 ekswięźniów, wobec których zastosowano technikę wywiadu jawnego, nieskategoryzowanego. Recydywiści przystępowali do badania dobrowolnie, po podpisaniu zgody na wykorzystanie materiału badawczego pochodzącego z ich narracji (pisemne treści pozyskane z wywiadów oraz transkrypcje zapisów rozmów z użyciem dyktafonu), jak również danych, których źródłem były kwestionariusze ankiet oraz pozostałe narzędzia badawcze.

Projekt badawczy zrealizowano w dwóch typach zakładów karnych dla recydywistów - półotwartym oraz zamkniętym. Do badań przystąpiło 670 recydywistów penitencjarnych (mężczyzn) odbywających karę izolacji więziennej, wyłonionych $\mathrm{w}$ celowo-losowym schemacie doboru próby badawczej oraz 30 recydywistów - ekswięźniów funkcjonujących na wolności, którzy odnieśli sukces reintegracyjny i jak dotąd nie powrócili do przestępstwa (łącznie 700 osób).

Badania nad porażką reintegracyjną ekswięźniów przeprowadzono w ramach dwóch ścieżek diagnostycznych. Krocząc pierwszą z nich, rozpatrywano wybrane aspekty przestępczego stylu życia, w tym przyczyny i konsekwencje jego wyboru: hierarchię wartości; umiejscowienie kontroli; sytuację ekonomiczną rodzin pochodzenia oraz rodzin własnych; style wychowania i postawy rodzicielskie (tym badaniem objęto tylko recydywistów posiadających dzieci); poczucie stygmatyzacji; problemy na rynku pracy. W tej części badania posłużono się metodą sondażu diagnostycznego, którą przeprowadzono z wykorzystaniem techniki ankiety i adekwatnego do niej narzędzia badawczego $\mathrm{w}$ postaci autorskiego kwestionariusza ankiety dla recydywistów penitencjarnych. Zastosowano także „Kwestionariusz Wartości” Miltona Rokeacha, w polskiej adaptacji Piotra Brzozowskiego: „Skala Wartości”, który umożliwia określenie preferowanych struktur w obrębie 18 wartości ostatecznych, stanowiących katalog celów 
życiowych oraz 18 wartości instrumentalnych (zbiory sposobów postępowania prowadzące do osiągnięcia postawionych celów) oraz „Skalę do Pomiaru Poczucia Umiejscowienia Kontroli” Juliana B. Rottera [Skala I-E (Inter-External Scale)] w przekładzie Radosława Ł. Drwala. Jest to skala typu Likerta, na którą składa się 29 par zdań, z czego 6 stanowi pozycje buforowe, pozostałe 23 mierzą poczucie kontroli w ten sposób, że wysoki wynik świadczy o zewnętrznym poczuciu kontroli, a niski o wewnętrznym. Opisane narzędzia posłużyły do zbadania 245 recydywistów.

Druga ścieżka diagnostyczna prowadziła do samodzielnego rozpoznania przez recydywistów przyczyn własnej powrotności do przestępstwa, ich autoidentyfikacji w świetle oceny osobistej porażki i właśnie to zagadnienie stanowi osnowę prezentowanej książki. W ramach paradygmatu interpretatywnego opracowano założenia metodologiczne badań własnych właściwe dla metod teorii ugruntowanej, osadzonej w nurcie symbolicznego interakcjonizmu. W badaniu posłużono się także techniką wywiadu indywidualnego bezpośredniego $\mathrm{z}$ użyciem dyktafonu oraz indywidualnego wywiadu narracyjnego $\mathrm{w}$ formie pisemnej. Zanalizowano i zinterpretowano dane pozyskane $\mathrm{z}$ bezpośrednich wywiadów indywidualnych oraz treści tekstów narracyjnych. Zastosowano metodę analizy dokumentów z wykorzystaniem techniki analizy treści, które mogą być cennym źródłem wiedzy o postawach, emocjach, poglądach i opiniach badanych recydywistów penitencjarnych. Przyjęte podejście pozwoliło na interpretację zgromadzonego materiału o charakterze intersubiektywnym oraz pozwoliło na odkrycie złożoności i wielości różnorodnych wątków w ramach przyjętych procedur i metodologicznych obwarowań [Szczepaniak 2012, s. 110]. Wypowiedzi skazanych przytoczono w wersji odpowiadającej oryginałowi, ale $\mathrm{z}$ nieznaczną korektą językową i interpunkcyjną. Przedstawiono je w sposób uniemożliwiający zidentyfikowanie autorów - każdej cytowanej wypowiedzi przypisano ogólne dane informacyjne zamieszczone w nawiasie [inicjały imienia i nazwiska (zakodowane), wiek, stan cywilny, kategoria miejsca zamieszkania, wielokrotność recydywy i rodzaj popełnionych przestępstw]. W tej części badania wzięło udział łącznie 455 osób, w tym 425 recydywistów osadzonych w zakładach karnych oraz 30 recydywistów-ekswięźniów, z którymi przeprowadzono badanie w warunkach wolnościowych.

Analiza danych socjodemograficznych wykazała, że ponad $1 / 3$ ogółu osób badanych stanowili mieszkańcy wsi i małych miast (do 20 tys. mieszkańców). Niemal równolicznie reprezentowane były osoby zamieszkujące duże miasta (powyżej 100 tys. mieszkańców). Pozostali recydywiści wywodzili się z miast średniej wielkości (20-100 tys. mieszkańców). W porównaniu z recydywistami jednokrotnymi recydywiści wielokrotni częściej mieszkali w dużych miastach. Prawie połowa ogółu badanych była w wieku średnim (31-40 lat). Najmniejszy odsetek badanych stanowili recydywiści w starszym wieku (powyżej 51 rż. — 10,3\%). Analiza danych dotyczących stanu cywilnego badanych więźniów pozwoliła ustalić, iż ponad połowa $\mathrm{z}$ nich nie posiadała rodzin własnych (kawalerowie), zaś $1 / 4$ ogółu badanych stanowili rozwodnicy i wdowcy żyjący samotnie lub w konkubinacie. 
W związkach sformalizowanych funkcjonowała jedynie 1/5 ogółu osób badanych. Niemal połowa badanych recydywistów nie posiadała kwalifikacji zawodowych $z$ uwagi na niski poziom wykształcenia (podstawowe lub gimnazjalne). Jedna trzecia z nich ukończyła szkołę zawodową, z czego ponad połowa poddana została oddziaływaniom reedukacyjnym $\mathrm{w}$ trakcie wcześniejszych pobytów w więzieniu. Tylko pięciu badanych recydywistów legitymowało się wyższym poziomem wykształcenia. Wśród badanych recydywistów jednokrotnych najwięcej osób było skazanych na kary krótko- i średnioterminowe. Symptomatyczne okazało się powielanie przez większość z nich czynów przestępczych, za które zostali skazani po raz pierwszy. Połowa recydywistów jednokrotnych odbywała wyroki za kradzieże, kradzieże z włamaniem, rozbój z użyciem niebezpiecznego narzędzia, zaś $1 / 5$ za jazdę samochodem pod wpływem alkoholu oraz posiadanie lub rozprowadzanie narkotyków. Niewielki odsetek badanych odbywał karę izolacji za niepłacenie alimentów oraz oszustwo, fałszerstwo lub wyłudzenie (po $5,0 \%$ ). Pozostali odsiadywali wyroki między innymi za znęcanie się nad rodziną, nieopłacenie zasądzonej grzywny, zabójstwo, udział w zorganizowanej grupie przestępczej czy handel bronią. Rozwój kariery przestępczej związany z powrotnością do rodzaju wcześniej popełnionych czynów odnotowano również w grupie recydywistów wielokrotnych. Analiza danych socjodemograficznych osób badanych umożliwiła nakreślenie statystycznego wizerunku recydywisty płci męskiej: jest to osoba stanu wolnego (kawaler, rozwodnik lub wdowiec), mieszkająca w niewielkiej enklawie społecznej (wieś lub małe miasto) lub w dużym mieście (powyżej 100 tys. mieszkańców), stosunkowo młoda (21-40 lat), legitymująca się niskim poziomem wykształcenia.

Dopełniające badania 30 recydywistów-ekswięźniów pozytywnie zintegrowanych ze społeczeństwem zostały przeprowadzone w latach 2018-2019. Docierano do nich za pośrednictwem mediów społecznościowych oraz osób mających z nimi bezpośredni kontakt. Byli to recydywiści wielokrotni w różnym wieku (28-51 lat), mieszkający w miejscowościach o różnej wielkości. Najwięcej osób funkcjonowało w średnich i dużych miastach - 24 osoby. Większość z nich była w związkach formalnych (21 mężczyzn), w tym 8 osób współtworzyło rodziny zrekonstruowane, zaś pozostali funkcjonowali w konkubinatach ( 6 osób). Odnotowano również trzech kawalerów. W większości przypadków ekswięźniowie lokujący się w badanej grupie posiadali wykształcenie zawodowe (21 osób). Wykształceniem wyższym zawodowym legitymowało się 8 osób, zaś wyższym magisterskim 2 osoby, które kontynuowały edukację po wyjściu na wolność, wskutek czego podniosły znacznie swój poziom wykształcenia. Ta grupa ekswięźniów została poddana badaniu z zastosowaniem techniki wywiadu jawnego, nieskategoryzowanego.

Z uwagi na wieloaspektowy charakter badania, jak również dużą objętość uzyskanego materiału badawczego, wyniki badania opartego na strategii ilościowej, odnoszące się do rozpoznania hierarchii wartości, problemów ekswięźniów na rynku pracy, poczucia stygmatyzacji, umiejscowienia kontroli oraz stylów wychowania, zostały wcześniej opublikowane [Nowak 2017, 2017a, 2017b, 2018, 2018a, 2019, 2019a]. 
Wprawdzie książka jest skonstruowana na podstawie badania zrealizowanego $w$ paradygmacie interpretatywnym, jednak w celu uzyskania pełnego oglądu rozpatrywanego zagadnienia, przy omawianiu niektórych jego aspektów posiłkowałam się wynikami badań ilościowych zamieszczonych wcześniej w wyżej wskazanych publikacjach. Podkreślenia wymaga także zastosowanie przeze mnie zabiegu odnoszącego się do wzmocnienia analiz teoretycznych poprzez egzemplifikację — podparcie wywodów materiałem badawczym pozyskanym $\mathrm{z}$ narracji badanych recydywistów.

Należy podkreślić, że do wyników analiz danych badawczych, pozyskanych z przeprowadzonych wywiadów i rozmów trzeba podejść ostrożnie. Były one bowiem prowadzone w warunkach opresyjnych i pomimo wysiłków badacza ukierunkowanych na stworzenie swobodnej i miłej atmosfery, badani recydywiści mogli zatajać niektóre niewygodne dla nich fakty. Mogli również dokonywać prób manipulacji, fantazjować czy też koloryzować relacjonowane zdarzenia oraz odczuwać niepokój w odniesieniu do rzeczywistego wykorzystania pozyskanych przez badacza informacji. Więźniowie są bowiem z reguły bardzo zainteresowani odbiorem swoich wypowiedzi, stosują techniki oszustwa oraz wykazują silną motywację do deformowania przekazywanych informacji [Kamiński 2006]. Należy także podkreślić, że w projektowaniu, organizacji i prowadzeniu badania, a zwłaszcza przy interpretacji uzyskanych wyników konieczne jest uwzględnianie specyfiki środowiskowej. W przypadku środowiska więziennego należy brać pod uwagę możliwość kontrolowania przez więźniów informacji przekazywanej badaczowi oraz ich dążenie do przedstawienia siebie i reprezentowanej grupy w jak najlepszym świetle [Czarkowski, Strzelec 2020].

Wydaje się zatem, że bardziej wiarygodne rezultaty uzyskano z indywidualnych wywiadów narracyjnych w formie pisemnej. Pogłębiona analiza tekstów zawierających opisy życiowych doświadczeń recydywistów uczestniczących w badaniu wskazuje na to, że była to dla nich swoista oczyszczająca terapia. Świadomość wagi problemu i prośba o dokonanie autodiagnozy sprawiły, że większość z nich chętnie i poważnie podeszła do problemu oceny własnych niepowodzeń. Badani recydywiści mieli czas na autorefleksję i zmierzenie się z przyczynami osobistej porażki readaptacyjnej. W trakcie pisania doświadczali retrospektywnego zanurzenia w swój własny, miniony świat — błędnych decyzji, pomyłek, ale i bolesnych, traumatycznych wydarzeń. Szczególnie cenne są odniesienia do porażek związanych z funkcjonowaniem osób badanych po zakończeniu kary izolacji i wyjściu na wolność. Już wstępny przegląd tych materiałów świadczył o tym, że najczęściej wracali oni do patogennego środowiska życia przed uwięzieniem i właśnie tam usiłowali ponownie wpasować się w jego ramy. Wysiłki te kończyły się fiaskiem, czego konsekwencją był powrót do radzenia sobie w sposób im wcześniej znany, czyli do ponownego popełniania czynów przestępczych.

Zaprezentowane w książce wyniki badania są obciążone subiektywną oceną dokonaną przez osoby badane oraz związanymi z nią zniekształceniami atrybucyjnymi pojawiającymi się zwykle w sytuacjach nietypowych [Meyer, 
Reisenzein, Schützwohl 1997, s. 258], do których niewątpliwie należy izolacja więzienna. Można oczywiście zastanawiać się i dyskutować nad tym, czy sytuacje wielokrotnego uwięzienia są typowe, czy też nietypowe dla recydywisty, ale z pewnością należy wziąć pod uwagę negatywne skutki izolacji więziennej, a zwłaszcza fizyczne i psychiczne zniewolenie.

Niniejsza książka jest opracowaniem interdyscyplinarnym, w którym odnaleźć można odwołania do dorobku wielu dyscyplin naukowych korespondujących z jej problematyką i powiązanych z ideą holistycznego ujmowania zjawisk patologicznych, w tym przestępczości i powrotności do przestępstwa. Nie ma ona jednak charakteru porządkującego wiedzę i systematyzującego dorobek naukowy w przedmiotowym zakresie. Moją intencją było bowiem skłonienie Czytelnika do refleksji i namysłu nad losem tych, którzy stracili życiową równowagę i uwikłali się w sytuacje zwieńczone odizolowaniem ich od reszty społeczeństwa. Ich sytuacja życiowa jest konsekwencją zaistnienia relatywnie sprzężonych ze sobą czynów i działań, ujętych w kategorialną triadę: winę, karę i wybaczenie. Praźródła skrzywionej trajektorii życiowej osób skazanych tkwią w środowisku ich życia (w rodzinie pochodzenia i grupie rówieśniczej) oraz w warunkowanych dziedzicznie i biologicznie obciążeniach, ograniczeniach i niemocach wewnętrznych.

Od zarania dziejów wszystkie państwa świata borykają się nieustannie z problemem przestępczości i recydywy. Są to problemy o charakterze uniwersalnym i ponadczasowym, osadzone w płynnej rzeczywistości, naznaczonej dużą dynamiką zmian kulturowych, społecznych i ekonomicznych oraz relatywną zmiennością warunków, które z założenia mają prowadzić do stabilizacji życia jednostek i grup społecznych w różnych kontekstach ich funkcjonowania. Stąd też wydaje się, że spełnienie wszystkich wypracowanych teoretycznie i podbudowanych empirycznie postulatów wytyczających drogę więźniów, a następnie ekswięźniów do pełnej reintegracji społecznej jest niemal niemożliwe. Należy jednak robić wszystko, by te patologiczne zjawiska minimalizować. I właśnie o tym jest ta książka - poprzez poznanie fragmentów historii życia, identyfikację przyczyn i analizę problemów prowadzących ekswięźniów do reintegracyjnego fiaska oraz głęboki namysł nad ich człowieczym losem, można i należy dokonać próby wyartykułowania propozycji usprawnienia dotychczasowego systemu reintegracji społecznej ekswięźniów.

Książkę tę adresuję przede wszystkim do osób zawodowo i woluntarystycznie wspomagających byłych więźniów w ich wysiłkach reintegracyjnych. Mam też nadzieję, że zainspiruje ona badaczy tej problematyki do podejmowania pogłębionych analiz różnorakich aspektów oraz zakresów tematycznych. Ufam też, że treści zamieszczone w tej książce, a zwłaszcza fragmenty opisów biograficznych, zainteresują młodych naukowców, doktorantów oraz studentów różnych kierunków studiów i wzbudzą w nich refleksję nad kondycją współczesnego człowieka.

Kończąc, chciałabym serdecznie podziękować Służbie Więziennej za umożliwienie mi realizacji projektu naukowo-badawczego zatytułowanego: „Porażka readaptacyjna w narracji recydywistów penitencjarnych”. Dziękuję przede 
wszystkim osobom pełniącym najwyższe funkcje kierownicze w Centralnym Zarządzie Służby Więziennej, a w szczególności ówczesnemu Dyrektorowi Generalnemu SW, gen. Jackowi Kitlińskiemu, Dyrektorowi Okręgowemu Służby Więziennej w Warszawie, Pani płk Annie Osowskiej-Rembeckiej oraz Dyrektorowi Biura Penitencjarnego płk. Andrzejowi Leńczukowi za organizacyjną pomoc i wsparcie $\mathrm{w}$ realizacji projektu badawczego. Podziękowania kieruję także w stronę kierownictwa oraz funkcjonariuszy więziennych pracujących w zakładach karnych dla recydywistów (Żytkowice i Siedlce) za życzliwość i nieocenioną pomoc w organizacji procesu badawczego. Szczególnie ciepłe wyrazy wdzięczności kieruję do moich seminarzystów - współrealizatorów badania - bez których niemożliwe byłoby zgromadzenie tak obszernego materiału badawczego oraz moich koleżanek, kolegów, znajomych oraz innych osób zaangażowanych $\mathrm{w}$ poszukiwanie ekswięźniów pozytywnie zintegrowanych społecznie. Przeprowadzone z nimi wywiady były dla mnie inspirujące i szczególnie ważne w kontekście rozważań nad propozycją zmian systemowych.

Pięcioletni, wieloaspektowy i trudny logistycznie projekt badawczy zaowocował niniejszym opracowaniem, które mam nadzieję przyczyni się do zmiany postrzegania społecznego osób opuszczających zakłady karne i uruchomi w społecznościach lokalnych siły społeczne niezbędne do kompleksowego ich wspomagania $\mathrm{w}$ podejmowanych wysiłkach readaptacyjnych, co prowadzić będzie do udanej reintegracji społecznej, a tym samym do wzrostu bezpieczeństwa powszechnego. 


\section{Część I}

\section{Zachowania przestępcze — od normy do patologii}





\subsection{Przestępczość i recydywa jako zjawiska patologiczne}

Od zarania istnienia ludzie żyją w świecie niezwykle złożonym, w swoim wielokształcie wręcz niemożliwym do dogłębnego spenetrowania i opisania. Sami również dotknięci są poliformizmem wynikającym z istnienia różnic indywidualnych (wewnątrzgatunkowych), wzmacnianym transmisją społeczno-kulturową. Wiele wytworów, przekazów i badań naukowych wskazuje jednak na to, że gatunek ludzki dotknięty jest także znaczną i znaczącą dychotomią przejawiającą się w jego biologii (np. płeć: kobieta-mężczyzna), anatomii (np. symetria ciała: strona prawa-lewa; przód-tył) czy w biegunowej wizji świata osadzonej w wyznawanej religii i dominującej kulturze (my-oni), przedzielonej grubą kreską normy i patologii zachowań społecznych.

W powszechnym mniemaniu „normą” jest pewna prawidłowość — zgodność z oczekiwaniami, regułami i wzorcami społeczno-kulturowymi przyjętymi przez daną społeczność. „Normalne” jest natomiast zachowanie człowieka, które postrzegane jest przez innych jako najczęściej występujące wśród osób reprezentujących daną kategorię wiekową [Pytka 2005]. Tę normalność wyznacza przyjęty kanon przeciętnych zachowań. Stąd też podstawowym kryterium oceny zjawisk patologicznych jest brak zgodności zachowania z powszechnie akceptowanym zbiorem wzorców zachowań ludzkich, prezentowanych w różnorodnych sytuacjach społecznych i kontekstach życiowych (np. rodzinnym, edukacyjnym, religijnym czy towarzyskim) oraz różnorodnych sferach życia społecznego (etycznej, estetycznej czy obyczajowej).

Termin ,patologia” etymologicznie wywodzi się z greki (gr. páthos choroba, cierpienie oraz lógos - słowo, nauka) i oznacza naukę o przyczynach chorób, mechanizmach ich rozwoju i przebiegu, objawach i skutkach. Początkowo stosowany był wyłącznie w naukach medycznych, jednak pod koniec XIX wieku zaczęto posługiwać się nim do opisu niekorzystnych zjawisk społecznych. Odnoszono go do zachowań człowieka naruszających podstawy stabilności życia społecznego i nawiązując do terminologii medycznej, pojmowano jako naukę o schorzeniach społecznych. Od tego czasu wielu naukowców próbowało i nadal próbuje sformułować jednoznaczną definicję patologii społecznej. Najbardziej szerokie i rozpowszechnione w świadomości społecznej jest odnoszenie tego pojęcia do zachowań jednostek i grup społecznych sprzecznych z wartościami danej kultury. Ujęcie to jest jednak jednostronne, gdyż podnoszona jest w nim ,inność” działania ukierunkowanego wyłącznie „na zewnątrz”. Pojęcie 
to poszerzył znacznie Adam Podgórecki [1969], który po pierwsze zastosował je do całych społeczeństw, a po drugie odniósł to zjawisko nie tylko do aktywności ludzkiej, ale także do działania instytucji i systemów społecznych. Co istotne, nie ograniczył się jedynie do zachowań niezgodnych z normami społecznymi. Powiązał je bowiem z postawami jako ich aktywatorami i wskazał, że patologią społeczną są te postawy i zachowania człowieka, które naruszają podstawowe normy etyczne i wyrządzają wymierne szkody społeczne. Stąd wniosek, że postawa czy zachowanie stają się patologiczne wskutek oceny i wskazania społecznego. Podobnego zdania są także autorzy innych, niewiele różniących się definicji objawowych — między innymi Jacek Wódz [1973] i Jerzy Jasiński [1986], którzy wzięli pod uwagę zakres i nasilenie występowania zachowań niezgodnych ze wzorami społecznymi, czy Jan Malec (1986), który akcentował skutki danego zachowania i jego destrukcyjną siłę.

Szeroką definicję omawianego pojęcia, a tym samym najmniej precyzyjną, sformułował Jerzy Kwaśniewski [1991], który potraktował patologię społeczną jako zbiór różnego typu dewiacji społecznych postrzeganych jako przejawy różnorakich form społecznych dolegliwości i traktowanych jako „zło”. W tym przypadku kryterium przyporządkowania stanowi dezaprobata społeczna (repulsja) w stosunku do zachowań jednostkowych, grupowych i zbiorowych wywołujących silne potępienie (dewiacja negatywna), która jest przeciwstawna wyższej od przeciętnej aprobacie społecznej (apulsja) zachowań wykraczających poza przeciętność i wywołujących społeczny podziw (dewiacja pozytywna). Inne stanowisko prezentuje w tej kwestii Janusz Sztumski [1995], który istnieniu dewiacji nadał status obiektywny. Podstawą tej tezy jest dostrzeganie przez ludzi dewiacji we własnym postępowaniu i zachowaniach innych osób, co powoduje, że akceptują oni przeciwdziałające im realne fakty społeczne (np. odpowiednie akty prawne) [za: I. Pospiszyl 2008]. Niezależnie od postrzegania zjawisk patologicznych (byt subiektywny versus byt obiektywny) obaj cytowani wyżej Autorzy są zgodni, że tego typu zjawiskom należy się przeciwstawiać, gdyż zachowanie patologiczne zawsze stoi w opozycji do wzorca zachowań przyjętego przez większość członków danej społeczności i obowiązującego jako standardowe.

W określaniu obiektywnych i uniwersalnych kryteriów oceny zachowań człowieka występują znaczne trudności, związane z koniecznością wartościowania zachowania patologicznego. Sprawa jeszcze bardziej się komplikuje, gdy próbujemy analizować normy obowiązujące w różnych systemach społecznych, biorąc za punkt wyjścia przyjęte ideologie. W historii świata, również tej najnowszej, odnotowujemy bowiem liczne przypadki ideologii patologicznych (np. antysemityzm, narodowy socjalizm czy marksizm) oraz systemów totalitarnych (np. faszyzm czy komunizm), ukształtowanych na wartościach dewiacyjnych. Wszystko wskazuje zatem na to, że określenie obiektywnych kryteriów oceny i identyfikacji zachowania lub działania patologicznego jest praktycznie niewykonalne, zwłaszcza że dane statystyczne ilustrujące zjawiska patologiczne są niepełne i z uwagi na ograniczenia metodologiczne - w wielu przypadkach również mało wiarygodne. Ponadto, problemy z uniwersalnym podejściem do 
oceny zjawisk społecznych wynikają również ze zmienności w czasie norm, poglądów i wartości oraz ich oceny, silnie zabarwionej subiektywizmem indywidualnym lub doznaniem wspólnotowym.

Mało użyteczne wydaje się także powszechnie przyjmowane kryterium ilościowe, głównie z uwagi na możliwość takiego przekroczenia zakresu występowania określonego zjawiska patologicznego, które sytuować je może w obszarze „zjawisk normalnych” (np. alkoholizm). To sprawia, że kryterium ilościowe nie może być ani obiektywnym, ani wyłącznym w ocenie zjawisk patologicznych. Może natomiast zwiastować ich pojawianie się. Dużo bardziej zobiektywizowane jest natomiast kryterium szkodliwości społecznej, gdyż dotyczy ono szkód materialnych i niematerialnych (np. wizerunkowych, psychicznych, emocjonalnych), wyrządzanych zarówno społeczeństwu jako całości oraz poszczególnym jego członkom, jak i jednostce przejawiającej określone zachowanie patologiczne. Stąd też wydaje się, że kryterium szkodliwości społecznej (zbiorowej, grupowej $\mathrm{i}$ indywidualnej) jest najbardziej znaczące w identyfikacji patologii społecznych.

Jak wynika $z$ tego krótkiego przeglądu ram definicyjnych omawianego pojęcia, podstawowym kryterium oceny i uznania za patologiczne określonych postaw, zachowań, sposobu czy stylu funkcjonowania, jest ich sprzeczność z celami i wzorami społecznymi (np. przestępstwa zagrożone sankcjami karnymi czy patologia instytucji) lub dezaprobata społeczna czynów o mniejszym stopniu społecznego zagrożenia (np. prostytucja czy hazard). Ogólnie rzecz biorąc, patologią społeczną można nazwać zachowania i działania szkodliwe dla społeczeństwa, naruszające przyjęty i powszechnie obowiązujący system norm i reguł społecznych.

W niniejszym opracowaniu za wiodące przyjęto sformułowanie J. Malca [za: Pospiszyl 2008, s. 17], które wskazuje, że

patologia społeczna jest ogót przypadków śmierci, obniżenia poziomu moralnego, pogorszenia samopoczucia i strat materialnych spowodowanych naruszeniem regut prakseologicznych, moralnych i prawnych oraz postepowaniem autodestrukcyjnym.

Ponieważ przestępczość jako taka wraz z szerokim spektrum jej przejawów i rodzajów wpisuje się w nakreślone wyżej ramy definicyjne, nie ulega wątpliwości, że recydywa (ponowne popełnienie przestępstwa) jest zjawiskiem patologicznym o znacznym zasięgu destrukcji z uwagi na powtarzalność i koszty społeczne wynikające $\mathrm{z}$ wielokrotnego izolowania skazanych oraz zjawiskiem spełniającym następujące warunki kryterialne [ibidem, s. 12]:

- narusza normy i wartości społeczne;

- jest zachowaniem destrukcyjnym mierzonym w skali potępienia społecznego;

- występuje w większej zbiorowości lub w skali masowej;

- wymusza wykorzystanie siły zbiorowej w celu przeciwstawienia się tego rodzaju problemowi. 
Recydywa jest określeniem zaczerpniętym $\mathrm{z}$ łac. recedere, co $\mathrm{w}$ języku polskim rozumieć należy jako „ponowna wpadka”. Prawnicy pojęciem tym określają powrót do przestępstwa, czyli ponowne jego popełnienie. Oznacza to, że podstawowym warunkiem uznania, że dany sprawca jest recydywistą, jest ustalenie, że wcześniej popełnił on przestępstwo, za które został ukarany. Recydywistą jest zatem ta osoba, która popełniła dwa lub więcej kolejnych przestępstw, niezależnie od ich oddalenia od siebie w czasie.

Prawo karne przewiduje podział recydywy na ogólną i specjalną. Recydywa ogólna dotyczy relacji między przestępstwem (nieumyślne-umyślne), karą (pozbawienie wolności-kara izolacji więziennej), a ponownym przestępstwem (podobne do poprzedniego — inne). Z kolei w ramach recydywy specjalnej wyróżnia się jej postać zwykłą i wielokrotną. Recydywa specjalna zwykła (art. $64 \S 1$ k.k.) jest wówczas, gdy sprawca uprzednio został skazany za przestępstwo umyślne na karę pozbawienia wolności i w ramach tej kary był osadzony $\mathrm{w}$ więzieniu przez co najmniej 6 miesięcy oraz gdy przed upływem 5 lat od odbycia tej kary popełnił kolejne umyślne przestępstwo podobne do tego, za które wcześniej został skazany. Warunkiem uznania recydywy za zwykłą jest drugie skazanie za umyślne przestępstwo podobne do przestępstwa, za które sprawca został poprzednio pozbawiony wolności, a nie do innego, popełnionego przez niego wcześniej. Z kolei recydywa specjalna wielokrotna, tzw. multirecydywa (art. $64 \S 2$ k.k.), dotyczy sytuacji, w której sprawca popełnia co najmniej trzecie przestępstwo oraz gdy spełnione są łącznie określone warunki. Po pierwsze, sprawca został wcześniej skazany w ramach recydywy zwykłej (art. 64 k.k., $\S 1$ ). Po drugie, odbył karę izolacji przez co najmniej rok (łącznie). I po trzecie - w ciągu 5 lat po odbyciu ostatniej kary (w całości lub w części) popełnił ponownie przestępstwo umyślne przeciwko życiu lub zdrowiu, przestępstwo zgwałcenia, rozboju, kradzieży z włamaniem lub inne przestępstwo przeciwko mieniu, popełnione z użyciem przemocy lub groźby jej użycia. Skutkiem recydywy wielokrotnej jest obligatoryjne skazanie sprawcy przestępstwa na karę pozbawienia wolności „w wysokości powyżej dolnej granicy ustawowego zagrożenia” oraz fakultatywnie - wymierzenie jej „do górnej granicy ustawowego zagrożenia zwiększonego o połowę".

W perspektywie prawnej zjawisko recydywy jest potwierdzeniem braku skuteczności kary orzeczonej w przeszłości. Świadczy też ono o tym, że zachowanie sprawcy (skazanego po raz pierwszy) nie uległo poprawie i nadal przekracza on normy życia społecznego lub też uporczywie lekceważy porządek prawny. Recydywa oznaczać może także postawienie złej prognozy resocjalizacyjnej lub niepełną kompatybilność katalogu środków ograniczania przestępczości z aktualnymi potrzebami. 


\subsection{Wybrane ścieżki angażowania się w przestępczość}

Od zarania dziejów ludzie zadają sobie pytanie o etiologię zła, o niegodziwe postępowanie człowieka godzące często w zdrowie i życie własne i cudze. Odpowiedź na to pytanie jest jednak niezwykle trudna i niejednoznaczna, gdyż przyczyny dewiacji i patologii zachowań ludzkich są wieloczynnikowo uwarunkowane (biologicznie, poznawczo, kulturowo, społecznie). Chcąc jednak podjąć rozważania na temat etiologii zachowań przestępczych, należy przyjąć tezę, że punktami odniesienia do ludzkiej aktywności, w tym działania przestępczego, są doświadczenia życiowe, sposób postrzegania świata społecznego oraz przetwarzania pozyskiwanych o nim informacji.

Za zaburzenia zachowania, w tym zachowania antyspołeczne, odpowiedzialne są zarówno czynniki osobowościowe, jak i środowiskowe [m.in. Niewiadomska 2007; Nowak 2011; Opora 2011; Kieszkowska 2012; Fidelus 2012; Szczepanik 2015]. Zgodnie $\mathrm{z}$ wynikami tych i wielu innych badań, osoby niedostosowane i wykolejone przestępczo posiadają cechy, które są skutkiem obciążeń genetycznych i/lub warunków środowiskowych, niesprzyjających ich wszechstronnemu i prawidłowemu rozwojowi. Wskutek tego oraz przy udziale różnorakich splotów okoliczności osoby te wykazują słabe zdolności przystosowawcze, głębokie deficyty kompetencyjne oraz zaburzenia poznawcze i emocjonalne.

W wyjaśnianiu mechanizmów adaptacyjnych specjalizuje się neuronauka kognitywna i psychologia poznawcza. Dzięki przyjęciu perspektywy ewolucyjnej, reprezentanci tych dyscyplin naukowych ukierunkowali swoje penetracje badawcze na porównawcze, międzygatunkowe badania procesów poznawczych. $\mathrm{Z}$ uwagi na to, że niemożliwe jest odtworzenie filogenezy ludzkiego mózgu podczas bezpośredniej obserwacji (nie podlega on fosylizacji), badacze zdecydowali się na identyfikację stopnia adaptacji systemu poznawczego zwierząt do warunków i wymagań środowiska. Wyniki tych eksploracji pozwoliły na postawienie tezy o ewoluowaniu ludzkich modułów poznawczych w kontekście ekologicznym. Dzięki temu możliwe stało się rekonstruowanie systemów poznawczych i wyodrębnienie określonych typów umysłów [Dennet 1991]. Badacze doszli także do wniosku, że rekonstrukcja funkcji poznawczych musi odbywać się w kontekście biologicznym, gdyż funkcje te są aspektami neurologicznych substratów, wyewoluowanych w toku przetwarzania określonych informacji i wykonywanych zadań. Badanie procesów poznawczych jest szczególnie interesujące dla psychologów poznania. Przyjmuje się, że są one procesami mentalnymi. Jednak trzeba w tym miejscu zastrzec, że takie procesy mentalne, jak: doznania, pragnienia czy uczucia, choć nie należą do kategorii procesów poznawczych, to w ich przebiegu pełnią znaczącą funkcję [Damasio 2000]. Z kognitywistycznego punktu widzenia opartego na dorobku współczesnej neurobiologii i psychobiologii realizatorem procesów mentalnych i poznawczych jest mózg, który odgrywa znaczącą rolę w interakcjach organizmu ze środowiskiem. Człowiek kontaktuje się z otoczeniem zewnętrznym przez zmysły. Rodzi to określone konsekwencje 
poznawcze, gdyż człowiek pozbawiony zewnętrznego otoczenia nie może prawidłowo rozwijać swoich kompetencji poznawczych i językowych [Dziarnowska, Klawiter 2006].

Teorie poznawcze są również użyteczne w wyjaśnianiu rozwoju zachowań przestępczych, gdyż są oparte na założeniu, że złożone procesy umysłowe odgrywają istotną rolę $\mathrm{w}$ kształtowaniu się ludzkiego zachowania. Umysł ludzki, określany jako układ poznawczy, posiada względnie trwałe właściwości, charakterystyczne dla naszego gatunku (jest to m.in. inteligencja, myślenie abstrakcyjne i twórcze, kompetencje językowe czy systemy pamięci trwałej i świeżej), niezmienne w tzw. czasie cywilizacyjnym, rozpatrywanym historycznie od starożytności do współczesności. Są to właściwości (zdolności) wrodzone, rozwijane pod wpływem środowiska społeczno-kulturowego. Struktury poznawcze stanowiące centralny składnik ludzkiej osobowości (system informacji wewnętrznych) kształtowane są przez indywidualne doświadczanie świata oraz odbiór, odkodowywanie i przekształcanie danych zewnętrznych. Treść zakodowanych informacji jest różnorodna — od sądów o środowisku naturalnym przez wiedzę o świecie społecznym i kulturze po samowiedzę (tzw. ,Ja” indywidualne i społeczne). Psychologowie poznawczy stoją na stanowisku, że to właśnie schematy poznawcze nadają sens (znaczenie) określonemu kontekstowi społecznemu i odpowiadają za procesy adaptacyjne. Dają one człowiekowi impuls do działania przystosowawczego oraz determinują rozpoznawanie i rozumienie przez niego rzeczywistości. Schematy są wzorcami poznawczymi rozwijanymi wskutek sprzężenia zwrotnego z segmentem świata zwanym środowiskiem. Ta swoista integracja wyznacza sposób postrzegania rzeczywistości oraz ukierunkowuje myślenie, zapamiętywanie i działanie [m.in.: Piaget 1981; Walters 2006a].

Schematy obecne są w każdej podejmowanej przez człowieka aktywności, gdyż rozwiązując problemy, działa on według określonego planu poznawczego. Treść zawarta $\mathrm{w}$ schematach wykorzystywana jest do analizy, zrozumienia i interpretacji bieżącej sytuacji oraz do przewidywania jej wpływu na przyszłe zdarzenia i sytuacje [Gannon 2009]. Dzięki procesom asymilacji (wbudowywanie nowej informacji do ukształtowanego wcześniej schematu) i akomodacji (modyfikowanie pojęć i czynności w celu wpasowania ich do nowo poznanych informacji i sytuacji wskutek czego następuje zmiana istniejących schematów lub tworzenie nowych), w kolejnych cyklach rozwojowych schematy łączą się ze sobą w bardziej rozwinięte struktury zwane schematycznymi podsieciami. Powstają one wskutek umiejętności dostrzegania związków pomiędzy schematami i tworzą specyficzny dla każdego człowieka system przekonań. Jest on najbardziej znaczącym, ale też ogólnym elementem hierarchicznego i bardzo złożonego systemu poznawczego, będącego głównym regulatorem ludzkich zachowań. Sieci wzajemnie powiązanych przekonań, skupionych w schematach ,ja" i w schematach świata społecznego, człowiek tworzy w ciągu całego swojego życia. To właśnie one pozwalają mu rozumieć zachowanie własne i innych osób oraz są źródłem jego oczekiwań wobec otoczenia [Greenwald, McGhee, Schwarz 1998]. Jednak nie wszystkie zasoby poznawcze są przez człowieka 
wykorzystywane, a niektóre z nich uruchamiane są przez niego nieświadomie [Nęcka, Orzechowska, Szymura 2007; Augoustinos, Walker, Donaghue 2006].

$\mathrm{W}$ procesie indywidualnego tworzenia obrazu rzeczywistości człowiek aktywuje konstruktywno-poznawcze strategie radzenia sobie, zaś w sytuacji zagrażającej wypracowanej przez siebie wizji świata, uruchamia strategie obronno-poznawcze [Walters 2006]. Zdolności te umożliwiają mu wykształcenie hierarchicznego systemu poznawczego, w którym podstawowym elementem jest schemat stanowiący wzorzec poznawczy. Na podstawie schematów poznawczych formujących się w toku interakcji ze środowiskiem, w specyficzny dla siebie sposób człowiek rozpoznaje i rozumie otaczającą go rzeczywistość [Piaget 1981; Bless, Fiedler, Strack 2004]

Liczne próby odpowiedzi na pytania dotyczące między innymi uwarunkowań optymalnego ludzkiego rozwoju, związków rozwoju poznawczego z charakterem i psychopatologią oraz wpływu niezaspokojonych potrzeb na rozwój człowieka, chronicznej frustracji czy urazów, podejmują również psychoanalitycy. Interesującym konstruktem teoretycznym, wywodzącym się z psychologii psychoanalityczno-rozwojowej, jest koncepcja Stephena M. Johnsona [1993, 2012], oparta na podejściu charakterologiczno-rozwojowym, która akcentuje uwarunkowania rodzinne w rozwoju zachowań przestępczych. Jedno z jej najbardziej istotnych założeń dotyczy przekonania, że charakter człowieka oraz źródła psychopatologii są efektem złożonej reakcji jednostki na frustrację wywołaną przez środowisko, związaną z brakiem zaspokojenia potrzeb różnej natury. Odpowiedzialne jest za to zwłaszcza środowisko rodzinne, gdyż od początku swojego życia dziecko konfrontuje się z podstawowymi ludzkimi problemami, które próbuje rozwiązać, mając do dyspozycji niewielkie zasoby własne (niewielkie indywidualne możności), ograniczenia środowiskowe i ubogą jeszcze wiedzę o świecie. W sytuacji gdy odbywa się to w kontekście środowiskowym o charakterze urazowym, takie wczesne rozstrzygnięcia mają tendencję do usztywniania się i są oporne na zmianę. W dużym stopniu za osobowość i psychopatologię odpowiedzialne są złożone, ale naturalne reakcje dziecka (metody radzenia sobie, adaptacji lub tłumienia) na frustrację wywołaną przez środowisko niezdolne do właściwej odpowiedzi na jego instynktowne potrzeby:

- przywiązania i więzi z podstawowym opiekunem [np. Bowlby 1969 i 1969a]; - indywiduacji poprzez samodzielne poznawanie środowiska, aktywność własną i budowanie granic psychicznych [np. Mahler, 1968];

- samodzielnie kształtowanej ekspresji [np. Kohut 1977; Lowen 1983].

Psychopatologia uwidacznia się zarówno w stłumieniu i wyolbrzymieniu reakcji, jak i nienaturalnej i nawykowej akomodacji w celu uniknięcia bólu towarzyszącemu kontaktom z innymi ludźmi. Problem charakterologiczny generuje deprywacja potrzeb typowych dla danej fazy rozwojowej, wynikająca z niedostatku zasobów biologicznych i środowiskowych (jednostkowych i grupowych). S.M. Johnson wyróżnił siedem rodzajów zaburzeń, z których każde stanowi continuum (od mniej do bardziej poważnych) i odzwierciedla istotne elementy ludzkiej natury, wokół których organizuje się osobowość człowieka. Ukazują 
one przede wszystkim znaczenie wczesnych relacji dziecka z rodzicami w procesie kształtowania się jego charakteru, osobowości i własnej tożsamości.

Rodzina jest pierwszym, najważniejszym i naturalnym środowiskiem życia człowieka, w którym przekazywane są mu wzory i postawy oraz normy, wartości, zasady i reguły postępowania społecznego. Jest to miejsce transmisji kulturowej, zaspokajania potrzeb podmiotowych i ponadpodmiotowych dające możliwość wszechstronnego rozwoju i zapewniające poczucie bezpieczeństwa. Jednak współczesny świat, tak wspaniale ukształtowany cywilizacyjnie, stawia człowieka nie tylko przed szerokim spektrum możliwości rozwojowych, ale także zagrożeń obecnych niemal we wszystkich sferach jego funkcjonowania. Sprawia to, że człowiek tkwi w oku psychologicznego cyklonu - przeżywa permanentny stres i raz za razem traci poczucie bezpieczeństwa. Nie odnajduje go często także w rodzinie, dotkniętej różnorakimi negatywnymi zjawiskami i patogennymi czynnikami (bieda, bezrobocie, uzależnienia od substancji psychoaktywnych lub/i czynności, dezintegracja lub autodestrukcja systemów rodzinnych, przeobrażenia form życia rodzinnego itp.). W życiu wielu rodzin dochodzi często do zawirowań decyzyjnych i zaburzeń związanych z niewypełnianiem przez nie ich podstawowych funkcji i powiązanych z nimi zadań. Długotrwały kryzys, z którym rodzina nie potrafi się uporać, skutkuje destabilizacją jej systemu [Nowak 2011]. W pułapkę kryzysu wieloproblemowego, silnie zagrażającego trwałości rodziny, wpadają te rodziny, które długotrwale tkwią w stanie bezradności, i które bez wspomagania zewnętrznego nie są w stanie realizować pomyślnie założonych funkcji. Należą do nich trzy spośród pięciu typów rodzin wyróżnionych w klasyfikacji Stanisława Kawuli [2004], poszerzonej o kryterium poziomu samodzielności rodziny oraz reakcji społecznej przez B.M. Nowak [2011 s. 58]:

- typ rodziny wydolnej wychowawczo, ale czasowo niesamodzielnej, z tendencją do autostabilizacji (system zagrożony dezorganizacją, wymagający wsparcia zewnętrznego o charakterze edukacyjno-profilaktycznym);

- typ rodziny niewydolnej wychowawczo, niesamodzielnej, dysfunkcyjnej (system zdezorganizowany i wymagający wspomagania zewnętrznego o charakterze terapeutyczno-resocjalizacyjnym);

- typ rodziny patologicznej, niesamodzielnej i głęboko dysfunkcyjnej, o skumulowanych czynnikach patologicznych (system wymagający podjęcia działań interwencyjnych o charakterze resocjalizacyjno-terapeutycznym).

Rodzina jest źródłem pierwotnych doświadczeń relacyjnych dziecka, w sposób szczególny wpływających na jakość jego życia i funkcjonowanie społeczne w dorosłości. W rodzinie funkcjonującej prawidłowo układ wzajemnych relacji zmienia się adekwatnie do wieku dziecka i jego potrzeb rozwojowych. Odmiennie jest w rodzinie dysfunkcjonalnej, dla której typowa jest sztywność pełnionych ról i wzorów relacyjnych. Oznacza to, że są one niedostosowane do zmieniających się dziecięcych potrzeb i wymogów rozwojowych. Przyjęty przez rodzinę model relacyjny wpływa na dobór metod wychowawczych stosowanych wobec dziecka, czyli celowych, planowych sposobów postępowania, ukierunkowanych 
na cele wychowania. Emocjonalny stosunek rodziców do dziecka i stosowane wobec niego metody składają się na styl wychowania — niepowtarzalny i dla każdej rodziny swoisty. To on decyduje o rodzaju komunikacji wewnątrzrodzinnej, sposobach sprawowania kontroli nad członkami rodziny, wyrażania uczuć, okazywania wzajemnego zrozumienia, postawach oraz zachowaniach w pozarodzinnych relacjach i układach społecznych. Styl wychowania jest zatem przyjętą przez rodzinę unikatową koncepcją wychowania dziecka, uruchamiającą mechanizm jego prawidłowego rozwoju versus generującą zaburzenia adaptacyjne emocjonalne i behawioralne. Jak wykazały badania Barbary Ostafińskiej-Molik i Ewy Wysockiej [2015], zaburzenia internalizacyjne (problemy w funkcjonowaniu interpersonalnym) występujące $\mathrm{u}$ dzieci, nasilają się $\mathrm{w}$ przypadku autokratycznej lub liberalno-kochającej postawy przejawianej przez ojca, zaś zaburzenia o charakterze wycofania, lękowo-depresyjne i zachowania niedostosowane wyzwalane są wskutek prezentowania przez matkę stylu demokratycznego lub autokratycznego oraz postawy liberalno-kochającej, lub niekochającej. Z kolei zaburzenia eksternalizacyjne, głównie skargi somatyczne lub zaburzenia depresyjno-lękowe, powiązane są z postawą demokratyczną i liberalno-kochającą przejawianą przez oboje rodziców.

Wszystko wskazuje więc na to, że pierwotnym źródłem zachowań dewiacyjnych i siedliskiem patologii społecznej jest wadliwie funkcjonujące środowisko rodzinne [m.in. Patterson, B.D. DeBaryshe, E. Ramsey 1989; Urban 2004; Kupiec 2008; Szymanowska 2008; Nowak 2011; Ostafińska-Molik, Wysocka 2015]. Dzieci wychowujące się w rodzinach głęboko dysfunkcyjnych (wieloproblemowych) i/lub patologicznych wykazują liczne przejawy niedostosowania społecznego. Są to między innymi: notoryczne kłamstwa, zachowania agresywne, nagminne wagary, nadużywanie środków psychoaktywnych, popełnianie czynów zabronionych (np. kradzieże, rozboje, włamania). Najrzadziej notowane są ucieczki dzieci z domu, co wskazuje na większy kryzys wychowawczy w szkole niż w rodzinie. Młodzi ludzie częściej doświadczają bowiem niepowodzenia szkolnego i wagarują niż decydują się na opuszczenie domu rodzinnego. Dzieci wychowujące się w rodzinach wadliwie funkcjonujących są często członkami grup negatywnych, gdzie są poddawane swoistej kontrsocjalizacji. Opanowują strategie maskujące zażywanie środków psychoaktywnych oraz unikowe w przypadku popełniania czynów zabronionych prawem. Symptomy niedostosowania społecznego dzieci występują częściej w tych rodzinach, w których co najmniej jedna osoba dorosła zamieszana jest w konflikt z prawem [Nowak 2011]. Problem ten występuje częściej w rodzinach o strukturze niepełnej niż pełnej oraz funkcjonujących w małych enklawach społecznych.

Najbardziej sprawczym regulatorem zachowania człowieka jest zbiór informacji wynikających z przeszłych doświadczeń. Wiedza ta staje się głównym źródłem jego motywacji działaniowych i budulcem spójnego systemu uogólnionych przekonań [Beck 1999, s. 21-22]. Człowiek kreuje w ten sposób własny obraz rzeczywistości, który traktuje jako właściwy i słuszny oraz użyteczny. W toku swojego życia identyfikuje przedmioty i zjawiska, gromadzi informacje 
o sobie i innych ludziach, poznaje własne i ich reakcje, buduje sieć relacji i przyjmuje zasady funkcjonowania społecznego. Zdobywając, gromadząc, interpretując oraz kreatywnie przetwarzając dane o świecie, układa własną hierarchię wartości i uczy się rozpoznawać ją u innych. Nadając tej wiedzy sens i znaczenie, człowiek staje się samodzielnym, świadomie i celowo działającym podmiotem kreującym swoje życie według własnego projektu. Szkicując osobisty, według siebie poprawny, obraz rzeczywistości i tworząc historię swojego życia, każdy człowiek uruchamia poznawcze strategie radzenia sobie, kształtuje swoją tożsamość oraz przyjmuje określone orientacje w świecie zewnętrznym. W ten sposób konstruuje własną mapę rzeczywistości.

$\mathrm{Na}$ temat procesu adaptacji nadal niewiele wiadomo, pomimo rozwoju nauki oraz doniesień z licznych, longitudinalnych badań. Nie ulega jednak wątpliwości, że ważnym etapem tego procesu jest radzenie sobie, rozumiane jako reagowanie człowieka w sytuacji doświadczania stresu. Jedną ze strategii radzenia sobie jest skoncentrowanie na emocjach. Stanowi ona indywidualny, wewnętrzny typ radzenia sobie, stosowany w sytuacjach doświadczanych w sposób traumatyczny jako próba osłabienia cierpienia i wygaszenia bolesnych myśli i uczuć. Działania zaradcze skoncentrowane na emocjach są podejmowane w następstwie nieskutecznych prób adaptacji. Jeżeli radzenie sobie rozumiemy jako pokonywanie trudności adaptacyjnych, to strategia tego typu nie jest przejawem ukierunkowania działania na pozbycie się stresu czy rozwiązanie problemu. Strategie zaradcze skoncentrowane na emocjach traktowane są jako potencjalne źródło negatywnych konsekwencji psychologicznych i zdrowotnych [Aldwin 1994]. Współcześnie panuje pogląd, że bardziej skuteczną strategią adaptacyjną jest radzenie sobie skoncentrowane na problemie [Lazarus i Folkman, za: Hobfoll 2006]. Chodzi tu o przystosowanie wskutek aktywnego rozwiązywania problemów. Interesująca jest w tym przypadku fuzja obu strategii. Jak już stwierdzono, działanie oparte na emocjach samo w sobie może zagrażać procesowi adaptacji, ale jako wzmocnienie wysiłków ukierunkowanych na rozwiązanie problemu strategia ta jest pomocna w zrewidowaniu już zastosowanej strategii i uzupełnieniu zasobów emocjonalnych i instrumentalnych. Skłania człowieka do otwarcia się na kontakty z innymi w poszukiwaniu wsparcia [Hobfoll 2006]. Proces adaptacji jest także opisywany jako proces selektywnej optymalizacji i kompensacji. Jest on rozpatrywany w ogólnym kontekście społecznym i historycznym, ale jednocześnie specyficznym z uwagi na unikatową biografię każdego człowieka oraz jego indywidualny przebieg rozwoju. Optymalizacja wiąże się z dopasowaniem zasobów do wymogów środowiskowych. Dążąc do optymalnego dopasowania, jednostka lub grupa kształtuje swoje zasoby oraz selekcjonuje i modeluje warunki zewnętrzne. Kompensacja $\mathrm{z}$ kolei, to proces gromadzenia, przystosowywania i udoskonalania zasobów w celu dostosowania się do zmian warunków środowiskowych. Jest to proces akceptacji deficytów przy jednoczesnym kreatywnym poszukiwaniu alternatyw [Baltes 1987; Baltes i Baltes 1990].

Nawiązując do tego wątku, warto wspomnieć o badaniach przeprowadzonych przez Renatę Szczepanik [2015] nad kształtem przestępczej biografii 
recydywistów i ich ponowną adaptacją do warunków wolnościowych. Wyniki badań pozwoliły Autorce na wyłonienie trzech strategii podejmowanych przez skazanych w celu zerwania z wizerunkiem kryminalisty, a tym samym zwiększenia szans na pozytywną readaptację społeczną:

1. Strategia ucieczki przed recydywą — polegająca na minimalizowaniu ryzyka powrotu do przestępstwa wskutek odizolowania się od dawnego środowiska przestępczego, założenie rodziny lub ustabilizowanie życia rodzinnego oraz podjęcie pracy zarobkowej w kraju lub za granicą. Są to działania zorientowane na unikanie powrotu do przestępczego stylu życia z wykorzystaniem nieprzestępczych zasobów środowiskowych zdobytych w trakcie pobytu w więzieniu. Symptomatyczna jest tu rola wsparcia społecznego traktowanego przez recydywistę jako narzędzie dyscyplinujące, powstrzymujące przed powrotem do dawnego, przestępczego stylu życia. Jest to jednak strategia obarczona ryzykiem porażki, szczególnie w odniesieniu do recydywistów z relatywnie małym doświadczeniem więziennym, ukierunkowana na odcięcie się od przeszłości. Recydywiści stosujący tę strategię, w sytuacji pojawiających się trudności i braku możliwości poradzenia sobie z nimi, przekierowują swoje działania na znane sobie w przeszłości sposoby i powracają do przestępstwa.

2. Kamuflowanie wizerunku recydywisty — odbywa się przez zmianę aktywności kryminalnej z brawurowej na zachowawczą. Chodzi tu przede wszystkim o doskonalenie dotychczasowej działalności przestępczej pod parasolem strategii ucieczki. Doświadczeni jej niepowodzeniem, świadomie podtrzymują dawne kontakty ze środowiskiem przestępczym, które stanowi dla nich swoisty bufor w sytuacji pojawienia się trudności, które przekroczyłyby ich możliwości poradzenia sobie z nimi. Jest to strategia świadomego balansowania pomiędzy dwoma subświatami: nieprzestępczym i przestępczym.

3. Konfrontacja - czyli strategia świadomego i intencjonalnego kierowania własną kryminalną przeszłością. $\mathrm{W}$ tym przypadku recydywiści mierzą się ze swoim przestępczym wizerunkiem poprzez identyfikację zasobów wynikających z minionych, więziennych doświadczeń i autentyczną wiarę w posiadanie możliwości powstrzymywania się od popełniania czynów przestępczych. Tę strategię stosują najczęściej byli przestępczy liderzy, silni osobowościowo, charyzmatyczni i kompetentni społecznie. Są oni postrzegani przez byłych wspólników jako osoby, które z wyboru zrywają kontakty ze światem przestępczym, a to pozwala im na wypracowanie w społeczności, w której żyją, przekonania o tym, że zostali zresocjalizowani.

Autorka badań podkreśla, że recydywiści są świadomi warunków koniecznych do życia i utrzymania się na wolności. Wiedzą, że jest to zależne od splotu okoliczności i wpływu czynników pośredniczących w osiąganiu powodzenia, którymi są zasoby indywidualne zgromadzone podczas pobytu w więzieniu wskutek oddziaływań resocjalizujących oraz zasoby środowiskowe, zwłaszcza w postaci wsparcia ze strony osób dla nich ważnych. Te dwa rodzaje zasobów muszą współwystępować, gdyż posiadanie tylko jednego ich rodzaju nie jest wystarczające do osiągnięcia sukcesu readaptacyjnego i znacznie zwiększa 
ryzyko powrotności do przestępstwa. Co istotne, badania wykazały, że praca zarobkowa wykonywana przez recydywistów na wolności pełni jedynie funkcję pośredniczącą $\mathrm{w}$ dochodzeniu do powodzenia reintegracyjnego. Ma ona znaczenie jedynie w przypadku recydywistów starszych wiekiem, dla których praca $\mathrm{w}$ połączeniu $\mathrm{z}$ silnym emocjonalnym wsparciem rodziny staje się punktem zwrotnym w procesie przerywania kariery instytucjonalnej. Najsilniejszym czynnikiem jest natomiast rodzina i wsparcie emocjonalne udzielane przez osoby bliskie, zwłaszcza kobiety.

\subsection{Teoria stylu życia Glenna D. Waltersa}

Wszystko to, co dzieje się z człowiekiem i jego otoczeniem, interpretowane jest przez niego na podstawie pięciu systemów przekonań odnoszących się do obrazu siebie i świata, stanowiących reprezentację rzeczywistości, na którą składają się: ocena siebie „W lustrze społecznym”; porównywanie się z innymi; reprezentacja siebie; świadomość odgrywanych ról; ,ja” możliwe. Doniosłą funkcję pełnią w tym procesie także obrazy teraźniejszości, przeszłości i przyszłości [Walters 2006c]. Na podstawie systemów przekonań człowiek przyjmuje typowy dla siebie sposób poznawania (styl poznawczy lub styl myślenia) prowadzący do ukształtowania się jego stałej postawy poznawczej [Messick 1996], zależny od względnie stałych różnic indywidualnych w zakresie spostrzegania, myślenia i uczenia się [Strelau 2002]. Człowiek dokonuje jednak często błędnych interpretacji, skutkujących zaburzeniami relacji z innymi. Dotyczy to między innymi osób niedostosowanych społecznie i/lub popełniających czyny przestępcze, które mogą uruchamiać schematy poznawczo-obronne z uwagi na niską samoocenę, zewnętrzne poczucie kontroli, zafałszowany pogląd na przeszłe uwikłania społeczne i sytuacje teraźniejsze oraz uwewnętrznioną, nierealistyczną wizję przyszłości.

G.D. Walters, autor teorii przestępczego stylu życia [1990 i 2006b], wyróżnia sześć schematycznych podsieci decydujących o systemie przekonań:

1. Atrybucje - są to skorelowane ze sobą grupy schematów, które umożliwiają wyjaśnianie zachowań własnych oraz innych osób. Atrybucje pełnią ważną funkcję w przystosowaniu człowieka do okoliczności życiowych, gdyż w sposób znaczący mogą osłabiać negatywne emocje, ale mogą też generować zachowania patologiczne, np. proces internalizacji siebie w roli zatwardziałego przestępcy przebiega w odniesieniu do globalnych i stabilnych atrybucji wewnętrznych [zob. Strelau 2002] (zagadnienie atrybucji omówione zostało szerzej w II części książki).

2. Poczucie skuteczności - jest to zespół przekonań jednostki na temat własnych możliwości, odgrywający główną rolę w podejmowaniu przez nią 
aktywności, w tym aktywności ukierunkowanej na popełnianie czynów przestępczych [zob. Bandura 1989 i 2007].

3. Oczekiwanie rezultatów - czyli antycypowanie własnego działania. Badania naukowe wskazują na przekonanie przestępcy o tym, że popełnienie czynu przestępczego podwyższy jego samoocenę oraz zredukuje negatywną ocenę społeczną [zob. Smithmyer, Hubbard, Simons 2000].

4. Cele - czyli grupy schematów organizujących i ukierunkowujących zachowania jednostki. Schematy rozwijane przez osoby popełniające przestępstwa akcentują krótkoterminowe korzyści wynikające z popełnianych przestępstw w stosunku do długotrwałych kosztów związanych z zachowaniem konformistycznym [zob. Krueger, Caspi, Moffitt i in. 1996].

5. Wartości - które stanowią schematy osobistych preferencji i priorytetów społecznych, zawodowych, intelektualnych i instynktownych. Te ostatnie zostały zidentyfikowane empirycznie jako grupa wartości związanych z natychmiastową gratyfikacją i odczuwaniem przyjemności, budująca specyficzny system wartości osób popełniających przestępstwa [zob. Ludwig, Pittman 1999].

6. Style myślenia - grupa schematów będących specyficznymi wzorcami myślowymi, wygenerowanymi wskutek interakcji poznawczego systemu obronnego (zaprzeczanie, zniekształcanie, usprawiedliwianie i zróżnicowanie) oraz błędów konstrukcyjnych (arbitralne wnioskowanie, dychotomiczne rozumowanie, minimalizacja, powiększanie, generalizacja, personalizacja).

Walters uważa, że ten określony, specyficzny sposób myślenia prowadzi jednostkę do aktywacji i ciągłego utrzymywania przez nią zachowań przekraczających prawo. Przekonanie to zakotwiczone jest zarówno w empirii, jak i w inspiracjach teoretycznych. Teoriami kluczowymi do powstania koncepcji przestępczego stylu życia były dla Waltersa:

- teoria zróżnicowanych powiązań E.H. Sutherlanda [por. Sutherland, Cressey, Luckenbill 1992], wyjaśniająca proces inicjacji przestępczej;

- teoria neutralizacji, odnosząca się do psychospołecznego procesu ułatwiającego popełnienie przestępstwa [Sykes, Matz 1957];

- koncepcja osobowości kryminalnej S. Yochelsona i S. Samenowa [1993], identyfikująca 52 błędy myślenia charakteryzujące osoby notorycznie dokonujące przestępstw.

Walters [1990] osadził swoją koncepcję na trzech bazowych, rozbudowanych założeniach:

1. Przestępczość staje się stylem życia wówczas, gdy sprawca będący osobą nieodpowiedzialną ${ }^{1}$ (lekkomyślną, impulsywną i niesolidną), usprawiedliwiającą się, nawiązującą nietrwałe więzi emocjonalne oraz wykazującą trudności w powściąganiu potrzeby natychmiastowej gratyfikacji i odczuwania przyjemności - powtarza czyny antyspołeczne. Co więcej, jest osobą dominującą,

1 W odniesieniu do osób cechujących się przestępczym stylem życia Walters traktuje tę cechę jako globalną i trwałą. 
natarczywą (nieszanującą praw i uczuć innych osób - impulsywną i agresywną), narzucającą innym swój sposób myślenia i działania, przekraczającą nie tylko normy prawne, ale także obyczajowe i moralne (wykazującą zaburzenia socjalizacyjne). Cechy te, a zwłaszcza nieodpowiedzialność z trudnymi do przewidzenia skutkami, są charakterystyczne dla osób prowadzących przestępczy styl życia i są determinowane głównie negatywnymi wpływami środowiskowymi — rodzinnymi, szkolnymi i rówieśniczymi.

2. Wejście na drogę przestępstwa spowodowane czynnikami psychologicznymi, społecznymi lub/i fizycznymi (interakcje człowieka ze środowiskiem) jest świadomą decyzją, na podstawie której podejmowana jest aktywność sprzeczna z ustanowionym prawem. Wolters wiąże popełnianie czynów przestępczych z zaspokajaniem potrzeb. Podstawowymi, dualnie zorganizowanymi motywacjami skłaniającymi jednostkę do popełnienia przestępstwa, są w teorii Waltersa: złość/bunt (potrzeba niezależności i autonomii); siła/kontrola (potrzeba sprawowania władzy nad otoczeniem); podniecenie/przyjemność (potrzeba stymulacji) oraz chciwość/lenistwo (potrzeba szybkiego osiągnięcia celu lub stanu czy też natychmiastowego zdobycia określonego dobra materialnego).

Aby doszło do przestępstwa, pojawić się musi jednak okazja, która warunkuje treść i sposób jego popełnienia. Walters zakłada, że czynnikiem wyjaśniającym wybór przestępczego stylu życia jest proces wyboru i podejmowania decyzji. W zestawieniu biegunowym wyróżnia czynniki chroniące jednostkę przed postępowaniem przestępczym oraz zwiększające prawdopodobieństwo wejścia na ścieżkę przestępstwa - ochrona siebie versus ryzyko oraz pozytywna zmiana siebie versus zmiana negatywna. Wybór opcji związanej z czynnikiem ryzyka i negatywna zmiana postępowania nieuchronnie prowadzą jednostkę do osobistego dramatu i załamania się trajektorii życiowej. Walters jest przekonany, że predyktorami decyzji i wyborów prowadzących do podejmowania zachowań przestępczych są najczęściej zestawione opozycyjnie dwa czynniki: lęk przed odpowiedzialnością (wybór — niepodejmowanie aktywności i decyzja — wycofanie) oraz niechęć do zachowań konformistycznych i społecznych konwenansów (wybór — podjęcie aktywności i decyzja - popełnienie czynu przestępczego). Autor teorii przestępczego stylu życia podkreśla jednak, że okoliczności i warunki społeczne, psychologiczne i środowiskowe nie aktywują w sposób bezpośredni zachowań przestępczych, ale zwiększają prawdopodobieństwo ich wystąpienia wskutek poszerzenia lub ograniczenia celów i wyborów, jakie przyjmuje i dokonuje człowiek w ramach swojego funkcjonowania. Pomimo tego, że przestępstwo jest efektem sprzężenia zwrotnego myśli, motywów i zachowań aspołecznych, to poszczególne rodzaje przestępstw są determinowane różnymi motywacjami, dominującymi w określonym działaniu przestępczym. Na przykład w przypadku kradzieży dominująca jest motywacja chciwości/lenistwa. Z kolei czyny o podłożu seksualnym charakteryzuje motyw podniecenia/przyjemności, a w przypadku gwałtów współwystępującym jest motyw siła/kontrola.

3. Wycofanie się z działalności przestępczej (zaniechanie zachowań przestępczych) jest skutkiem nie tylko zmiany dotychczasowych postaw wobec przyjętego 
i akceptowanego powszechnie porządku społecznego (skuteczna, pozytywna i trwała resocjalizacja i readaptacja społeczna), ale także zmiany indywidualnej hierarchii wartości i światopoglądu. Wszystko to prowadzi do ponownego zintegrowania się jednostki z poprawnie funkcjonującą większością społeczeństwa.

Osoby, które dokonały wyboru przestępczego stylu życia, cechuje przestępczy styl myślenia, który został zdefiniowany przez Waltersa jako specyficzna treść myślenia oraz proces inicjujący i utrzymujący zachowania związane z notorycznym łamaniem prawa. Oznacza to, że systemy poznawcze takich osób są upośledzone. W zakresie poznawania rzeczywistości pojawiają się bowiem zniekształcenia treściowe i asocjacyjne, co może prowadzić do rozwoju zaburzeń osobowości [2002].

Style myślenia przestępczego powstają w wyniku przepływu wybiórczych informacji pozyskiwanych z otoczenia do hermetycznych kategorii, tworzących nadmiernie ogólne i uproszczone reprezentacje poznawcze, generujące zachowania stereotypowe - zdeterminowane biologicznie, powtarzające się i opierające na subiektywnych założeniach. Style myślenia przestępczego generują zniekształcony obraz sytuacji oraz sprawiają, że jednostka jest przekonana o możliwości redukcji własnych lęków (opanowania zaburzających emocji) i napięć wskutek wejścia na kolizyjną ścieżkę w warunkach sprzyjających popełnieniu czynu przestępczego [Walters 2002]. Tego typu myślenie uaktywnia mechanizmy obronne, które uruchamiają zachowania sztywne, przymusowe, determinowane przeszłością oraz powiązane z pierwotnymi procesami myślowymi i nieświadomością. Dla przestępczego stylu myślenia charakterystyczna jest obecność moralnych mechanizmów obronnych [Strelau 2000, s. 616-617], pozwalających jednostce postrzegać siebie wciąż jako dobrego człowieka, pomimo naruszania własnych zasad moralnych. Należą do nich:

a) racjonalizacja czynu przestępczego jako środka do pozyskania większego dobra;

Dopuściłem się rozboju z użyciem niebezpiecznego narzędzia, czyli napadłem na sklep, bo po wyjściu z więzienia nie miałem kasy na życie. Pracy nie mogłem znaleźć. Ciężko było, bo wcześniej siedziatem i dużo osób o tym pamięta. Alimenty chciatem sptacić, dzieciakowi coś kupić... no to musiałem to zrobić [A.W. — 42 lata, rozwiedziony, wykształcenie średnie, mieszkaniec średniej wielkości miasta, recydywista jednokrotny, wyroki skazujące za kradzież i rozbój]

b) eufemizmy (nazywanie określonych rodzajów przestępstw mniej negatywnymi nazwami);

Pierwszy raz siedziałem za kradzieże, ale drugi wyrok to już dostatem za rozbój. Proszę Pani, jaki to byt rozbój! To była przecież tylko próba przywtaszczenia mienia. Owszem, sięgnąem facetowi do torby w tramwaju, on zacząt wrzeszczeć, że złodziej... Blisko już byt przystanek, no to go popchnątem, on się wywrócit, a ja wyskoczytem z tramwaju, ale ktoś mi nogę 
podstawit, no i doszło do obywatelskiego zatrzymania (śmiech)... [P.N. 35 lat, rozwiedziony, wykształcenie podstawowe, mieszkaniec dużego miasta, recydywista jednokrotny, wyroki skazujące za kradzież i rozbój]

c) porównywanie własnych czynów przestępczych z jeszcze poważniejszymi czynami innych osób;

Siedze tu za kradzieże, a przecież ja za każdym razem tylko tam byłem i nic nie kradtem. Wszystko mi przypisali, ale ok. — trochę sobie sam na to zapracowatem, od młodości i poprawczaka. Czasem też tak sobie myślę, że ja to Pan Pikuś jestem - tu siedza tacy, co to narkotyki dzieciakom sprzedawali, mordowali, gwatcili. No i prosze - siedzimy razem... [A.K. 30 lat, kawaler, wykształcenie podstawowe, mieszkaniec wsi, recydywista czterokrotny, wyroki skazujące za kradzieże]

\section{d) dzielenie się winą z innymi (rozmycie odpowiedzialności);}

Odsiaduje 1,5 roku za straszenie żony, bo mi z córka nie pozwalata sie spotykać. To jej wina, bo uparta i wredna z niej kobieta. Znalazła sobie kogoś i wie Pani co? Każe mojej córce nazywać go tatusiem, a o mnie zapomnieć, bo kryminalista jestem. Ona mnie nie interesuje, niech się spotyka z kim chce, ale córka jest moja i mam prawo mieć z nia regularny kontakt, no nie? Przeciez praw rodzicielskich nie mam odebranych. Gdybym wiedziat, że za to trafię do więzienia, to zniszczytbym ten telefon [R.A. - 32 lata, rozwiedziony, wykształcenie średnie, mieszkaniec wsi, recydywista jednokrotny, wyroki skazujące za jazdę skuterem bez kasku i po alkoholu oraz groźby karalne]

e) przemieszczanie odpowiedzialności (uzasadnianie czynu przestępczego poprzez wskazywanie na jego popełnianie przez osoby pełniące ważne funkcje społeczne lub autorytety);

W zakładzie jestem już szósty raz, licząc także tymczasowe aresztowania. Byty to kilkuletnie pobyty. Karany bytem za jazdę autem po alkoholu $i$ za handel narkotykami. Choć ja twierdzę, że dawatem ludziom szczęście. Byty to osoby petnoletnie, trafiali się urzędnicy, a nawet raz pracownik prokuratury. Pewnego razu spotkaliśmy się w sadzie po przeciwnej stronie (śmiech)... [K.D. - 45 lat, żonaty, wykształcenie zawodowe, mieszkaniec wsi, recydywista dwukrotny, wyroki skazujące za kradzież oraz rozbój]

f) ignorowanie negatywnych konsekwencji własnych czynów przestępczych (wyparcie konsekwencji);

W czasie ostatniego pobytu na wolności bytem kelnerem, ale niedtugo kilka miesięcy. Pracowałem też w pizzerii, ale też dtugo tam miejsca nie zagrzatem. Ogólnie to kasa z moich interesów była. Pracować nie trzeba 
było. Mam swoje mieszkanie, jak znów wyjdę, to może poszukam jakiejś roboty. Spotkam się ze znajomymi. Zobaczymy. Do dilerki nie chciałbym wrócić, ale jak trzeba będzie, to wrócę... [D.L. - 36 lat, kawaler, wykształcenie zawodowe, mieszkaniec dużego miasta, recydywista trzykrotny, wyroki skazujące za kradzieże oraz posiadanie narkotyków]

\section{g) dehumanizacja ofiar swoich czynów;}

Odsiaduję wyrok za próbę zabójstwa. Żonę swoja chciatem ukatrupić, bo to suka byta. Podta, zawzięta, bez sumienia. Jak mówita do mnie, to jakby pies szczekat - w kótko to samo: ",pieniadze daj, do roboty idż”. No tak... w matym mieście to pracy dla takiego jak ja nie ma. Wszyscy się znaja, a ja przecież w kiciu siedziałem, to po co komu taki pracownik [J.F. - 46 lat, rozwiedziony, wykształcenie zawodowe, mieszkaniec małego miasta, recydywista jednokrotny, wyroki skazujące za kradzież oraz próbę zabójstwa]

h) zewnętrzna atrybucja winy — obwinianie ofiar o prowokację;

Kłótnia, kłótnia, jeden strzat pięścia w głowę i wyrok - dwadzieścia pięć lat! On za dużo powiedziat rzeczy, ja go zaczątem bić i chtop zszedt. Gdyby nic nie mówit albo nie tak ostro, że aż mi się łeb zapalit, albo gdybym zadzwonit na pogotowie, albo na policje i powiedziat ,no stuchajcie...”, ale ja chłopa ukryłem i znaleźli go po póttora roku i tak to już wyszło [I.G. 40 lat, żonaty, wykształcenie zawodowe, mieszkaniec średniego miasta, recydywista jednokrotny, wyroki skazujące za kradzież z włamaniem oraz morderstwo]

Przestępczy styl myślenia charakteryzuje osiem dymensji (wzorów poznawczych) służących usprawiedliwianiu własnej lekkomyślności, impulsywności, natarczywości i niesolidności oraz łamania zasad życia społecznego [Walters 1989, 2006a, 2006b]:

1. Uśmierzanie - dokonywanie prób przeniesienia winy własnej na różnorakie okoliczności zewnętrzne; osoba reprezentująca taki wzorzec myślenia jest przekonana, że jej aspołeczne zachowanie jest tylko nic nieznaczącym przejawem w skali globalnej niesprawiedliwości i nieuczciwości ludzkiej.

2. Odcięcie - ucieczka od odpowiedzialności przez lekceważenie kary kryminalnej, bycie „ponad” groźbą sankcji prawnych za własną aspołeczność.

3. Roszczeniowość - przyzwolenie na własne działania łamiące prawa, normy i reguły społeczne, wynikające z przekonania o posiadaniu prawa do zachowań innych niż obowiązujące i aprobowane społecznie.

4. Infantylizm uczuciowy - sentymentalizm wykorzystywany do gry pozorów: eksponowanie bycia uczciwym i niewinnym, pomniejszanie własnej winy, pozytywna autoprezentacja oraz podkreślanie swoich teraźniejszych i przeszłych dobrych uczynków i słabości. 
5. Zorientowanie na siłę - dzielenie ludzi na słabych lub silnych i lokowanie siebie w grupie dominującej nad grupą „słabych” i rozporządzającej nią wedle własnego uznania w celu odczuwania własnej mocy sprawczej i osiągania kontroli nad otoczeniem.

6. Hiperoptymizm — nadmierna pewność siebie i przecenianie własnych możliwości, wskutek czego pojawia się odrealniona wizja konsekwencji własnych czynów przestępczych. Zazwyczaj jest to przekonanie o własnej bezkarności.

7. Bierność poznawcza - lenistwo, znudzenie, niechęć do wysiłku zarówno fizycznego, jak i umysłowego, skutkujące ubogim światem wewnętrznym i poszukiwaniem podniet $\mathrm{w}$ otoczeniu i działaniem opartym na własnych, często irracjonalnych pomysłach.

8. Brak ciągłości działania — niekonsekwencja w myśleniu i działaniu, tzw. słomiany zapał oraz przekraczanie uzgodnień i zrywanie umów.

Koncepcja G.D. Waltersa stała się na gruncie polskim inspiracją dla Magdaleny Rode do podjęcia badań nad wyróżnieniem przestępczych stylów myślenia u nieletnich oraz warunkujących je czynników psychospołecznych i osobowościowych. Wyniki tych badań [2013, s. 268-269] wyraźnie wskazują na zróżnicowaną etiologię wzorów myślenia przestępczego i potwierdzają silne oddziaływanie na ich rozwój czynników biologicznych i kulturowych (uwarunkowania typu gender). W kształtowaniu się trwałych dyspozycji percepcyjnych potwierdzony został determinujący udział obserwacji najbliższego otoczenia społecznego, a szczególnie osób najbliższych (znaczących). Badania wykazały również dwuczynnikowość myślenia przestępczego: myślenie roszczeniowo-defensywne (skłonność do unikania i ignorowania czynników powstrzymujących przed dokonaniem czynu przestępczego) oraz myślenie bierno-zależne (skłonność do manipulacji i braku odpowiedzialności, niekonsekwencja oraz zależność od innych). Co więcej, badania pozwoliły na wyodrębnienie predyktorów stylów myślenia przestępczego, którymi są: praktyki wychowawcze generujące problemy emocjonalne i zachowania aspołeczne dzieci; właściwości psychospołecznego funkcjonowania matek i przyjmowane przez nie postawy rodzicielskie oddziałujące stymulująco lub destymulująco na właściwości osobowościowe dzieci. Należy podkreślić, że z uwagi na różne warunki rozwojowe (opiekuńczo-wychowawcze i postawy rodzicielskie), a tym samym zróżnicowany przebieg socjalizacji, u dzieci kształtują się zróżnicowane treściowo systemy poznawcze wraz z jednoczesnym rozwojem zniekształceń poznawczych.

Etiologia zaburzeń zachowania jest wieloczynnikowa i wielowymiarowa. Są one determinowane biologicznie, kulturowo, społecznie i środowiskowo. W rozwoju zaburzeń zachowania fundamentalne znaczenie ma kontekst rodzinny. Niesprawność środowiska rodzinnego i wynikające $\mathrm{z}$ niej braki w zasobach (osobowych i grupowych) są bowiem źródłem zaburzeń rozwojowych i psychopatologii oraz praprzyczyną zaburzeń w zachowaniu dzieci i młodzieży.

Funkcjonowanie dziecka w rodzinie głęboko dysfunkcyjnej i/lub patologicznej, może w dorosłości skutkować przestępczym stylem myślenia i przejawianiem zachowań dewiacyjnych. W grupie ryzyka lokują się najczęściej osoby, 
które w dzieciństwie i/lub wczesnej młodości wychowywały się w rodzinach i/ lub funkcjonowały $\mathrm{w}$ grupach rówieśniczych prezentujących wzorce myślenia i postępowania korelujące $\mathrm{z}$ zachowaniami przekraczającymi normy społeczne. W takich przypadkach dostarczane są dzieciom wzorce negatywne, a często wzory kryminalne, które poprzez naśladownictwo są przez nie przejmowane i internalizowane. Na uwarunkowania rodzinne zaburzeń w zachowaniu oraz zachowań przestępczych wskazują liczne wyniki badań naukowych. Informują one między innymi o tym, że za taki stan rzeczy odpowiedzialne są przede wszystkim:

a) cechy rodziny - pochodzenie, postawy i role rodzicielskie, które mogą wyzwalać mechanizm zaburzeń adaptacyjnych (emocjonalnych oraz behawioralnych) i mogą stanowić źródło problemów rozwojowych dzieci oraz zaburzeń w ich zachowaniu [np. Wysocka, Ostafińska-Molik 2015];

b) deficyty w zasobach osobistych rodziców (m.in. niski poziom kompetencji społecznych, umiejętności w zakresie wyrażania i rozpoznawania emocji, rozwiązywania konfliktów, komunikowania się z innymi ludźmi, radzenia sobie z kryzysami rozwojowymi oraz prowadzenia negocjacji w przypadku konfliktu interesów, unikanie interakcji społecznych lub wycofywanie się z dotychczasowych kontaktów) [Nowak 2011];

c) deficyty w zasobach rodzinnych (materialnych — niski status ekonomiczny; energii — niski poziom wykształcenia małżonków/partnerów, bieda i brak uczestnictwa w życiu społecznym i kulturalnym; stanu — wieloletnie bezrobocie, choroby przewlekłe, uzależnienia, przestępczość i niedostosowanie społeczne dzieci [np. Nowak 2011];

d) niekorzystne wzory przywiązania, aktywowane przez procesy defensywne $\mathrm{w}$ relacjach dziecka $\mathrm{z}$ innymi ludźmi: przywiązanie unikające koreluje z niedostosowaniem społecznym, agresją i przestępczością, zaś dezorganizacja przywiązania w niemowlęctwie wykazuje silny związek z późniejszymi problemami adaptacyjnymi: zaburzenia opozycyjno-buntownicze, symptomy dysocjacyjne, lęk, agresja, przejmowanie kontroli i dominacja [np. Levy i in. 1998; Thompson 1999; Brzezińska 2005; Plopa 2007];

e) styl rodzicielski charakteryzujący się wrogim nastawieniem, odrzuceniem, stosowaniem przymusu lub brakiem nadzoru, który sprzyja powstawaniu zaburzeń rozwojowych: zachowania agresywne, przestępcze, porażka edukacyjna, zaburzenia psychiczne, zachowania ryzykowne [m.in. Barnes, Farrel 1992; Plopa 2007];

f) zdrowie psychiczne i psychiczny dobrostan rodzica determinuje przebieg rozwoju psychicznego dziecka, zaś brak zaspokojenia potrzeb psychicznych może uruchomić mechanizm jego wykolejenia [m.in. Kujawa 2011; Sitarczyk 2004];

g) nieprawidłowe postawy rodzicielskie prezentowane przez ojców bezrobotnych oraz matki niezadowolone z sytuacji w pracy oraz reagujące wzmożoną nerwowością generują niższy poziom przystosowania społecznego dzieci [m.in. Kornacka-Skwara 2002]. 
Interesujące są także wyniki badania przeprowadzonego przez Mieczysława Plopę [2007]. Wykazały one wyraźną zależność między percepcją postaw rodzicielskich a przystosowaniem szkolnym badanej młodzieży. Dzieci rodziców okazujących im miłość i troskę nie przejawiają trudności adaptacyjnych w środowisku szkolnym i znacznie częściej prezentują zachowania pozytywne niż negatywne. Młodzież z zaspokojoną przez rodziców potrzebą miłości i akceptacji przenosi pozytywne emocje do środowiska rówieśniczego. U młodzieży odrzuconej przez rodziców występują natomiast nasilone trudności przystosowawcze oraz dominacja zachowań negatywnych. Brak akceptacji rodzicielskiej, okazywany chłód emocjonalny i odrzucenie przez rodziców skutkują pojawianiem się u dzieci stanów silnego napięcia wewnętrznego, zagrażających ich zdrowiu psychicznemu.

Przytoczone wyniki badań odzwierciedlają kondycję wielu współczesnych rodzin dotkniętych różnorakimi negatywnymi zjawiskami destabilizującymi ich systemy. Czynników erodujących życie rodzinne jest wiele. Są one różnej natury, posiadają różną siłę oddziaływania, zasięg i moc dezintegrującą. Poczucie zagrożenia wzmagają zawirowania społeczne i polityczne, zjawiska wzbudzające niepokój, zagrażające zdrowiu i życiu ludzkiemu (np. fatalny stan środowiska naturalnego, pandemia wirusa SARS-CoV-2 czy nasilające się niepokoje społeczne). Bieda, bezrobocie, szerokie spektrum uzależnień od substancji psychoaktywnych i uzależnień czynnościowych, dezintegracja lub autodestrukcja systemów rodzinnych oraz przeobrażenia form życia rodzinnego są pochodną dynamicznych zmian cywilizacyjnych, społeczno-gospodarczych i kulturowych. Sytuacje traumatyzujące i permanentnie odczuwany stres sprawiają, że coraz więcej rodzin nie radzi sobie z problemami i tkwi w obezwładniającym kryzysie, a ich członkowie tracą poczucie bezpieczeństwa i stabilizacji życiowej. Wszystko to staje się pożywką dla rozwoju nieprawidłowych postaw rodzicielskich oraz aspołecznych i antyspołecznych zachowań dzieci i młodzieży.

\subsection{Rola przestępcy w perspektywie interakcyjnej i transakcyjnej}

Rozważania nad rolą przestępcy zacząć należy od refleksji na temat roli uspołecznienia w kreowaniu konstytutywnych cech człowieka i jego dobrostanu. Inspiracją do podjęcia szczegółowych analiz były dwie przeciwstawne koncepcje socjologiczne. Pierwsza, forująca „człowieka nowoczesności” akcentuje brak udziału społeczeństwa $\mathrm{w}$ twórczym procesie stawania się tym, kim jesteśmy. Całą zasługę przypisuje nam jako istotom zatomizowanym, które razem z sobie podobnymi indywiduami budują strukturę społeczną. Druga koncepcja, opozycyjna, wskazuje wyraźnie na wyłączną rolę społeczeństwa w kształtowaniu 
człowieka, podkreślając jego społeczną naturę i postrzegając proces socjalizacji jako kluczowy w generowaniu ,społecznych podmiotów działania” oraz ich aktywność ukierunkowaną na tworzenie struktury społecznej.

Te dwie perspektywy łączy najbliższa mojemu rozumieniu roli uspołecznienia w ludzkim stawaniu się i funkcjonowaniu, komplementarna koncepcja Margaret Archer [2000], przedstawicielki realizmu społecznego. Uważa ona, że społeczeństwo wnosi pewien wkład w rozwój konstytutywnych cech człowieka, ale znacząco mniejszy niż jego wyposażenie biologiczne. Refleksyjność i sprawstwo zdaniem Archer mają największy udział w rozwoju świadomości oraz tożsamości osobistej i społecznej. Refleksyjność jest emergentną własnością ludzi, dzięki której uruchamiany jest proces mediacji pomiędzy strukturami społecznymi i kulturowymi a jednostkowym sprawstwem [2012]. Archer podkreśla, że każdy człowiek odgrywa postać zapisaną w kodzie biologicznym, kreowaną przez ślepą, demoniczną siłę, natręctwo czy jak u Freuda - moc przeznaczenia. Innymi słowy, dzięki długotrwałemu przyleganiu obie te postacie - zarówno ta, która wyrasta z kodu biologicznego, jak i ta, która wykreowana zostaje poprzez powielanie wzoru społecznego zrastają się z człowiekiem i istnieją w nim jako schematy. Żyjąc w społeczeństwie, człowiek zmuszony jest stać się postacią daną mu jako rola społeczna. $\mathrm{W}$ niewielkiej tylko mierze role społeczne wnikają z tzw. powołania, gdyż są nieuniknionym wytworem interakcji społecznych. Stąd też człowiek często odczuwa odgrywaną przez siebie rolę jako przymus, albo narzuconą samemu sobie dyscyplinę. W rolach społecznych, które człowiek przyjmuje i odgrywa w różnych fazach swojego życia oraz w różnych jego kontekstach, ukryte są techniki urzeczywistniania uznanych przez społeczeństwo wartości. Można zatem przyjąć, że postać ukształtowana w wyniku odgrywania ról społecznych tworzy się $\mathrm{w}$ toku wielofazowego, niewidocznego i długotrwałego procesu kreacji. Przebywając nieustannie w różnych kontekstach życiowych i zmieniając je w toku podejmowanej aktywności, człowiek odgrywa swoje role w ciągu swoistych performansów. Kreuje je w zależności od sytuacji i okoliczności, w jakich się znajduje oraz własnych i cudzych potrzeb dotyczących społecznego i wspólnotowego działania [Szechner 2007, s. 16].

W ujęciu Ervinga Goffmana [2007] performans charakteryzuje się tym, że w kontaktach społecznych jednostka dąży do wywarcia określonego wrażenia na pozostałych uczestnikach interakcji. Ich finalnym efektem jest „Ja” przypisywane jej przez innych, „Ja”, z którym skłonna jest się identyfikować. Człowiek w interakcji zbliża się do opisywanej przez egzystencjalistów postaci człowieka wrzuconego w sytuację, w której gra się zawsze o jedną i tę samą stawkę o wytworzenie i podtrzymanie wiarygodnego (także we własnych oczach) wizerunku „Ja” jako kogoś, kto czuje się dobrze w swojej skórze (potocznie mówiąc: jest w porządku). Co więcej, interakcje sprowadzają się do zrytualizowanej gry o zyski, w której uczestnicy są skrępowani skonwencjonalizowanymi zasadami zachowania czy postępowania — zawsze przytłaczającymi, niezależnie od środowiska, w którym gra się toczy (wolnościowego czy izolacyjnego). 
W analogiczny sposób kształtuje się także rola przestępcy — sprawcy czynu podlegającego odpowiedzialności karnej przed sądem, uznanego przez prawo za przestępstwo kryminalne.

Goffmanowska wizja kształtowania się roli społecznej jest niemal spójna z psychologiczną koncepcją Erica Berne’a [1961], która powstała na podbudowie psychoanalizy, psychologii uczenia się, teorii komunikacji społecznej oraz psychologii humanistycznej. Zdaniem jej autora, niemal wszystkie interakcje są transakcjami, w których chodzi o zdobycie wymiernych korzyści: społecznych, psychologicznych czy egzystencjalnych. Wszystkie interakcje, począwszy od rytuałów do gier, są ściśle ustrukturyzowane, ale to właśnie gry są najbardziej skomplikowane, zawsze podstępne i ukierunkowane na zdobycie różnorakich korzyści. Są one również ambiwalentne, gdyż z jednej strony programują ludziom czas i dają poczucie równowagi, z drugiej zaś rujnują ich życie. Poprzez transakcje człowiek urzeczywistnia pewien życiowy scenariusz (ang. script), wyrastający z dziecięcych iluzji i zakodowany w nieświadomości. Strukturalizując swój czas, wypełnia go rytuałami, rozrywkami i grami. Stają się one źródłem satysfakcji i przynoszą wymierne korzyści. W ten sposób człowiek wnosi coraz to nowe elementy do życiowego scenariusza, nie zdając sobie nawet $\mathrm{z}$ tego sprawy.

$\mathrm{Na}$ gruncie analizy transakcyjnej wypracowano wiele metod i technik terapeutycznych oraz rozwojowych, wspomagających jednostkę w osiągnięciu autonomii. Składa się na nią [za: Hay 2010, s. 19]:

a) świadomość - czyli kompetencja rozpoznawania własnych doznań i uczuć w odpowiedzi na bieżącą rzeczywistość oraz odrzucania reakcji emocjonalnych należących do przeszłości;

b) alternatywa - rozumiana jako przekonanie, że zawsze istnieje więcej niż jeden możliwy sposób zachowania, i że wolność osiąga się przez wybór jednej opcji z wachlarza potencjalnych możliwości;

c) przywiązanie - które jest zdolnością do podjęcia interakcji otwartej, pełnej zaufania, pozwalającej na uzewnętrznienie emocji i uzyskanie pełnej akceptacji.

Koncepcja Erica Berne'a pozwala na rozpoznanie ukrytego programu życia, będącego skutkiem negatywnych wpływów rodzicielskich i jest niezwykle przydatna w rozumieniu konfliktów międzyludzkich i ich przeciwdziałaniu, zwłaszcza w kontekście tzw. wygrywania i przegrywania życia.

\subsection{Konflikt i negocjacje w teorii światów społecznych Anselma Straussa}

Podejście akcentujące negocjowany porządek interakcyjny jest reprezentowane między innymi przez Howarda Beckera, Carlsona Tuckera, Normana Denzina, 
Barry'ego Wellmana i Anselma Straussa, którzy stoją na stanowisku, że aktorzy społeczni będący podstawową siłą sprawczą, są zdolni do autonomicznego działania w świecie uporządkowanym społecznie i kulturowo. Pojawiające się sytuacje zmuszają ich jednak do podjęcia aktywności ukierunkowanej na interpretację nowych okoliczności i dostosowanie się do określonych reguł, wykorzystując zdolności oraz motywacje do tworzenia i przetwarzania znaczeń. Aktor społeczny swoje zadanie konstruowania działania może wykonać byle jak, ale musi je wykonać [Blumer 2007, s. 15]. Oznacza to, że jest on zmuszony do podjęcia aktywności i negocjowania swojej pozycji w sytuacjach pojawiających się w ustalonym porządku społecznym. Aktywność ta zależna jest od jego obecności w sieci licznych interakcji, gdzie wraz z innymi aktorami odgrywa swoją rolę W swoistych spektaklach na społecznej scenie. W toku transakcji ocenia siebie i swoje działania w perspektywie sytuacji zdefiniowanych wspólnie z innymi podmiotami. Odgrywa role, wykonuje czynności społeczne, a w procesie komunikacji dokonuje samoregulacji.

Koncepcja światów społecznych autorstwa A. Straussa osadzona jest na fundamencie interakcjonizmu symbolicznego, uwzględniającego perspektywę społeczno-organizacyjną. Zainspirowana została koncepcją sieci uczestnictwa Tamotsu Shibutaniego [1994], warunkowanej kanałami komunikacji będącymi kreatorami specyficznych obszarów kulturowych. Koncepcja Straussa jest uniwersalna i „heurystycznie płodna”. Ma ona wprawdzie wiele ograniczeń, ale bazowa kategoria świata społecznego - określana przez jej autora jako zestaw podzielanych $i$ wspólnych jego uczestnikom czynności lub pogladów, powiązanych ze soba za pomoca sieci komunikacji [Strauss 1982, s. 171] — jest niezwykle wszechstronna. Perspektywa ta pozwala uchwycić diachroniczną zmienność wewnątrz całości społecznych, gdyż w tak zdefiniowanym świecie ludzie jednoczą się i angażują we wspólną, osiową aktywność. Wokół niej koncentruje się życie społeczne, a wspólnota odmiennych zainteresowań i interesów prowadzi do jej wewnętrznego zróżnicowania, do konsolidacji mniejszych grup — do swoistego ,pączkowania” subświatów.

Strauss przyjął, powstające wskutek procesów transsytuacyjnych zachodzących w ciągu życia człowieka, dwie podstawowe kategorie - niepowtarzalną tożsamość osobistą oraz tożsamość społeczną, która formuje się nie tyko w toku spotkań bezpośrednich, ale także jest nadbudowywana wskutek oddziaływań systemów interakcji i relacji społecznych. Dostrzegł bowiem znaczenie trwających w czasie, zorganizowanych systemów interakcji, w których ludzie odgrywają swoje społeczne role, podkreślając tym samym znaczenie grupy w transformacjach tożsamościowych. Strauss rozumie tożsamość jako efekt związków jednostki z osobami będącymi z nią w interakcji, wskutek czego staje się ona kimś innym niż dotychczas i podkreśla nieodwracalną transformację percepcji. Koncepcja tożsamości propagowana przez Straussa akcentuje wage i rolę języka naturalnego w porządkowaniu i organizowaniu świata, w procesie refleksji nad sobą i innymi, w rozpoznawaniu i ocenie składowych sytuacji 
związanej z działaniem ludzkim oraz transakcyjny charakter ról społecznych i ich kulturowych przyporządkowań.

Interakcyjne ujmowanie transformacji osoby wyrasta $\mathrm{z}$ przekonania, że w ciągu życia podlega ona symbolicznemu procesowi konceptualnych zmian dokonujących się $\mathrm{w}$ efekcie przeobrażeń aparatu pojęciowego, które implikują z kolei zmiany w postrzeganiu przez nią rzeczywistości, zapamiętywaniu i wartościowaniu. To właśnie wówczas, w procesie zmian tożsamościowych aktywowanych poprzez interakcje $\mathrm{z}$ innymi, pojawiają się punkty zwrotne (momenty kryzysowe). Dzieje się tak zwłaszcza wtedy, gdy człowiek wyobraża sobie siebie $\mathrm{w}$ działaniach powiązanych z pozycją społeczną. Strauss, podobnie jak Lesli McCall [2003, s. 327-348], wyodrębnił biegunowe reakcje interakcyjne. Jeżeli bowiem system poznawczy jednostki, kreujący jej tożsamość i role społeczne, nie dostrzega sprzeczności z komunikatami otrzymywanymi od innego uczestnika interakcji, wówczas dochodzi do konsensusu tożsamościowego. Jeżeli jednak taka sprzeczność się pojawia, wówczas mamy do czynienia $\mathrm{z}$ wejściem w konflikt z przypisywaną rolą.

Koncepcja społecznych światów A. Straussa umożliwia opis, analizę i interpretację, przedzielonych grubą, Goffmanowską kreską subświatów „normalsów”, „kryminalistów” i „byłych kryminalistów”. Pomaga zrozumieć swoisty melanż czasoprzestrzeni, gdy owe subświaty koegzystują, przenikając się za sprawą różnorakich interakcji oraz pozwala w sposób zadowalający uchwycić nie tylko sposób organizacji i funkcjonowania tych specyficznych obszarów ludzkiego bytowania w ich efemeryczności i płynności, ale także rozpoznać zachodzące w nich relacje. 
Naukę można traktować [...] jako szczególny poddział ludzkiej aktywności zmierzajacej do ustalenia prawdziwych przekonań dotyczacych zdarzeń i procesów zachodzacych w naszym świecie.

Sam Harris [2012, s. 295] 



\section{Część II \\ Ocena przyczyn powrotności do przestępstwa - uwikłania interpretacyjne}



Nie ulega wątpliwości, że prowadzenie badań w instytucjach totalnych, takich jak więzienia, jest trudne i uciążliwe nie tylko dla badaczy, ale również dla osób nimi zarządzających oraz pełniących różne funkcje — ochraniające, dozorujące, wychowawcze czy wreszcie terapeutyczne. Wejście na teren instytucji izolowanej i obwarowanej bezwzględnymi procedurami bezpieczeństwa zaburza ustanowione sztywne reguły i zasady postępowania, rytm dnia oraz zakłóca przyjęty tok postępowania ukierunkowanego na zapewnienie bezpieczeństwa wewnętrznego. Problemem jest także ograniczony dostęp osób postronnych do tego typu instytucji ze względu na unormowania prawne. Stąd też osoby decydujące się na eksploracje empiryczne w jednostce penitencjarnej muszą się liczyć z pojawieniem się sytuacji mogących znacznie utrudnić lub wręcz uniemożliwić realizację założonego schematu badawczego.

Szczególnie trudna jest sytuacja badacza realizującego projekt w warunkach izolacji więziennej zwłaszcza wówczas, gdy przeprowadza on wywiady z osadzonymi. Wymaga to bowiem wytworzenia przyjaznej atmosfery i nawiązania takiej nici porozumienia z osobami badanymi, które sprzyjałyby otwarciu i szczerości ich wypowiedzi [Szczepanik, Śliwerski 2017]. Jest to jednak zadanie bardzo trudne z uwagi na niechęć skazanych do ujawniania rzeczywistych poglądów czy motywów działań [Chomczyński 2013 i 2017; Bielska 2016]. Wszystko to sprawia, że analiza danych narracyjnych pozyskanych w toku badania jest skomplikowana i pełna niepewności interpretacyjnych. Największym problemem jest jednak nierozwiązana kwestia wiarygodności osób badanych, których wypowiedzi mogą być naznaczone między innymi kłamstwem, manipulacją, obciążone falsyfikacją przekazu wynikającą z zaburzeń poznawczych czy skłonnością do konfabulacji. Stąd też rzetelna analiza przekazu narracyjnego wymaga posiadania przez badacza umiejętności interpretacyjnych wykształconych na wysokim poziomie.

Treści zamieszczone w tej części opracowania nawiązują do atrybucji przyczynowych, wyjaśniających osiągane sukcesy lub doznawane przez ludzi porażki, do znaczenia stereotypów w przetwarzaniu informacji i przypisywaniu winy oraz do roli pamięci autobiograficznej w procesach atrybucji przyczynowych i adaptacji społeczno-psychologicznej. Taki dobór treści powiązany jest z przedmiotem badań własnych, których wyniki są opisane w kolejnej części książki. Podparcie omawianych zagadnień biograficzną narracją osób badanych miało na celu przygotowanie Czytelnika do odbioru danych i wyników badania. Prezentowane treści i stanowiska teoretyczne zostały niejako wzmocnione fragmentami wywiadów narracyjnych z badanymi recydywistami, którzy dokonywali analizy własnej powrotności do przestępstwa na podstawie retrospekcji przeżyć i różnorakich zdarzeń z przeszłości. Jest to bowiem książka o Nich i dla Nich. W cytowanych fragmentach wypowiedzi pochodzących z wywiadów, recydywiści poszukują przyczyn własnych porażek readaptacyjnych, a my razem z nimi dochodzimy do sedna ich wielokrotnych niepowodzeń przystosowawczych. 
Należy podkreślić, że zdecydowana większość wypowiedzi osób badanych została przytoczona w brzmieniu oryginalnym. W wielu przypadkach konieczna była jednak niewielka korekta językowa. W oryginalnych tekstach dokonywano modyfikacji stylistycznych, gramatycznych i interpunkcyjnych, z dbałością o zachowanie pierwotnego wydźwięku korygowanych wypowiedzi.

\subsection{Wyjaśnianie przyczyn zdarzeń — przegląd wybranych koncepcji atrybucji}

W procesie wyjaśniania zachowań ludzkich znaczącą rolę odgrywają atrybucje przyczynowe. W myśl dotychczasowej wiedzy psychologicznej umożliwiają one identyfikację zarówno czynników prowadzących ludzi do osiągania sukcesów lub doznawania porażek, jak i czynników mogących modyfikować proces formułowania sądów o sobie i/lub innych ludziach [Alicke 2000]. Są to aspekty szczególnie ważne $\mathrm{w}$ diagnostyce niedostosowania społecznego i zachowań przestępczych. Badacze tej problematyki, psychologowie, kryminolodzy, pedagodzy czy socjologowie, napotykają jednak na duże trudności w uzyskaniu rzetelnej wiedzy o przyczynach i uwarunkowaniach zachowań niezgodnych z obowiązującymi regułami życia społecznego i/lub godzących w ludzkie zdrowie i życie. Pomimo tego, dochodzenie do źródeł przestępczości ma ogromne znaczenie nie tylko $\mathrm{w}$ procesie określania winy i wymierzania adekwatnej do niej kary, ale także - o ile nie ważniejsze - w procesie readaptacji i reintegracji społecznej.

Podstawowe założenie teorii atrybucji dotyczy przekonania, że poszukiwanie przez człowieka praw rządzących przyrodą i zjawiskami społecznymi jest jedną z jego podstawowych czynności intelektualnych. Stąd też w modelach wyznaczników atrybucji stawiana jest fundamentalna teza, że ludzie wnioskują o przyczynach zachowań własnych i cudzych w sposób podobny do naukowców poszukujących prawdy o świecie. Opierają się na dostępnych im informacjach pozyskanych z różnych źródeł, przetwarzają je podobnie jak statystycy i dokonują w miarę spójnej syntezy. Trzeba jednak pamiętać, że jest to wewnętrzne przekonanie dotyczące istnienia związków przyczynowo-skutkowych dla obserwowanych zdarzeń, sytuacji i zachowań. Innymi słowy, teorie atrybucji odnoszą się nie tyle do odnalezienia przez człowieka przyczyn zachowań (własnych i cudzych), co do wewnętrznego przekonania, że zostały one przez niego rozpoznane jako źródła obserwowanych skutków.

Jeśli więc skonfrontujemy zachowanie osób niedostosowanych i wykolejonych społecznie z ich obciążeniami genetycznymi oraz warunkami środowiskowymi niesprzyjającymi ich wszechstronnemu i prawidłowemu rozwojowi, to będzie to zgodne z atrybucjami normatywnej części społeczeństwa, czyli z intuicyjnym skonstruowaniem łańcucha przyczynowo-skutkowego. Osoby niedostosowane 
społecznie i wykolejone będą również budowały łańcuch przyczynowo-skutkowy, ale na bazie własnego postępowania, w odniesieniu do podejmowanego przez siebie działania, osiąganych celów i zajmowanej pozycji społecznej, czyli będą dokonywać atrybucji na swój temat.

Ponieważ człowiek pragnie zrozumieć otaczający go świat oraz dąży do tego, by czuć się dobrze ze sobą i z innymi ludźmi, to dokonywane przez niego atrybucje są pełne różnych mechanizmów osiągania poczucia dobrostanu.

Pierwsze badania (eksperymenty) nad skłonnością człowieka do strukturalizowania zdarzeń w kategoriach przyczynowości osobowej i jej wpływu na spostrzeganie zostały zainspirowane ideą głoszoną przez filozofów (m.in. Hume’a i Milla), że fundamentalnymi źródłami spostrzeganej przyczynowości są styczność czasowa i przestrzenna oraz podobieństwo.

David Hume, szkocki filozof, historyk i ekonomista żyjący w XVIII wieku zakładał, że całość świata dostępnego naszemu poznaniu skondensować można w postaci impresji, czyli doznań zmysłowych, dzięki którym możemy doświadczać rzeczywistości zewnętrznej [2005, s. 233]. Ich pochodną są idee formowane w ludzkim umyśle pod wpływem różnego rodzaju rozumowań. Hume przyjął, że własnością ludzkiego umysłu są specyficzne sposoby przepływu jednych idei do drugich: podobieństwo, styczność w czasie i przestrzeni oraz przyczyna i skutek. Podkreślał przy tym, że relacje czasoprzestrzenne nie mają statusu rozumowania - ma go natomiast stosunek przyczyn do skutku. Jego zdaniem, rozumowanie przyczynowo-skutkowe umożliwia człowiekowi odkrywanie prawdy w sposób wykraczający poza zbiór danych pamięciowych i doznań zmysłowych, gdyż wnioskowanie przyczynowe operuje faktami i ma charakter syntetyczny. Wnioskowanie o przyczynie danego zdarzenia, zachowania czy działania jest jednak warunkowane jednoczesną obecnością:

- bezwzględnej styczności zaistniałych faktów;

- pierwszeństwa pojawienia się jednego z nich w czasie — przyczyna musi poprzedzać skutek;

- powiązania odnoszącego się do uniwersalizmu i powszechności stosunku pomiędzy dwoma zdarzeniami, wskazanego przez Hume'a jako najistotniejsze. Na bazie powyższego zestawienia Hume wyprowadził definicję relacji przyczynowej: Połaczenie dwóch rzeczy w stałym, powtarzającym się porzadku styczności i następstwa, pozwala na nazywanie jednego przyczyna, a drugiego skutkiem [2005, s. 244]. Wskazał również, że umysł ludzki wykazuje skłonność do przyjmowania założenia, iż poza doświadczanymi przypadkami istnieją inne, do nich podobne.

Poglądy Hume'a stały się inspiracją do powstania koncepcji przyczynowości lokującej się w obszarze naukowego realizmu, którą w kolejnym stuleciu opracował John Stuart Mill, angielski filozof, politolog i ekonomista. W swoim rozumowaniu Mill częściowo nawiązywał do myśli Hume’a i rozważał przyczynowość fenomenologicznie, postrzegając ją jako relację pomiędzy zjawiskami, ale dostrzegł pewną nową zależność - wpływ warunków pozytywnych i negatywnych na zmianę stanu rzeczy [Mill 1882, s. 237-241]. Sformułowanie 
tezy o złożoności procesów oraz zwrócenie uwagi na brak zasadności wskazywania niektórych z nich jako ważnych, ze względu na ich przypuszczalne powiązanie przyczynowe, jest niekwestionowaną zasługą Milla w rozważaniach o przyczynowości.

W przeciwieństwie do Hume'a, Mill uważał, że następstwo czasowe nie jest warunkiem koniecznym do zaistnienia relacji przyczynowej, gdyż wiele procesów zachodzi równocześnie, a ponadto zdarza się, że określony skutek trwa pomimo ustania jego przyczyny. Inne argumenty dotyczyły skłonności ludzi do przypisywania określonym zjawiskom różnych przyczyn, w zależności od kontekstu oraz możliwości istnienia przyczyny niekoniecznie powiązanej z wystąpieniem przypisywanego jej skutku. Jest to założenie obecności warunków przeciwdziałających pojawieniu się koniecznego efektu.

Mill rozważał również taką sytuację, w której dane zdarzenie/działanie uznane zostaje za przyczynę wskutek pojawienia się szczególnych okoliczności definiujących je jako sprawcze, ale z których obecności obserwator nie zdaje sobie sprawy. Chodzi zatem o to, że dana przyczyna może zostać uznana za sprawczą również w sytuacji, gdy nie został zaobserwowany jej skutek — zjawisko to określane jest mianem tendencji [1882, s. 319].

Ważnym spostrzeżeniem sformułowanym przez Milla jako zalecenie jest konieczność odróżnienia procesów rzeczywistych od pozornie mających charakter przyczynowy. Mill wskazuje tu na postrzegane następstwo czasowe jako sprawcę ewentualnego zamieszania (np. wnioskowanie, że przyczyną zaistnienia dnia jest poprzedzająca go noc) i w celu doprecyzowania różnic, formułuje podstawowy warunek uznania przyczynowości przypisywanej niezmiennej sekwencji zdarzeń: nie mogą one być zależne od zdarzeń nieobserwowanych w sekwencji.

Rozważania Hume’a i Milla są podwaliną rozważań teoretycznych i badań empirycznych (eksperymentów) prowadzonych przez współczesnych psychologów nad uwarunkowaniami i przyczynami ludzkich zachowań oraz podejmowanych działań. Główną przyczyną zainteresowania badaczy sposobami dokonywania atrybucji są wynikające $z$ nich konsekwencje. Ten nurt penetracji empirycznych został zainicjowany przez Fritza Heidera i Marianne Simmel [1944], którzy jako pierwsi rozpoczęli badania nad rekonstrukcją potocznego sposobu wyjaśniania przyczyn ludzkich zachowań.

\subsubsection{Koncepcja naiwnej przyczynowości Fritza Heidera}

Pierwszą teorię atrybucji, zwaną „naiwną teorią przyczynowości” opracował F. Heider [1958]. Zakładała ona możliwość wnioskowania o nieznanej przyczynie zachowania na podstawie jego wyniku i jednej z możliwych przyczyn.

W odniesieniu do przedmiotu badania można to założenie zilustrować następująco: jedną z możliwych przyczyn popełnienia rozboju z użyciem niebezpiecznego narzędzia [działanie + przyczyna znana (brak pracy i środków do życia)] oraz ponownego skazania ekswięźnia na karę izolacji więziennej [wynik 
działania: powrotność do przestępstwa], może być domniemanie o jego nieudanej readaptacji społecznej po poprzednim skazaniu, odbyciu kary i wyjściu na wolność [wnioskowanie o przyczynie nieznanej]. Taki tok rozumowania można przypisać badaczom i naukowcom zajmującym się problematyką przestępczości. Obserwatorzy niezwiązani z działalnością naukową mogą jednak dokonywać zupełnie innych atrybucji, o czym świadczą między innymi wpisy internautów pod informacjami medialnymi o aktach przemocy.

Heider dostrzegł również możliwość prognozowania wyniku działania na podstawie rozpoznania tylko jednej przyczyny danego zachowania, co potwierdzają liczne badania naukowe [m.in. Larson, Lochman, za: Fronczak 2017; Glick, Gibbs 2011]. Zilustrować to może następujący przykład:

Gdy rozpoznaną przyczyną powtarzających się zachowań agresywnych dziecka jest rodzinny wzorzec socjalizacyjny, to można przypuszczać, że $\mathrm{w}$ dorosłości przeniesie ono ten wzorzec na grunt rodziny własnej.

W modelu atrybucji przyczynowej Heidera kluczowa jest teza mówiąca o tym, że zachowanie człowieka jest efektem/konsekwencją komplementarnego oddziaływania na niego czynników wewnętrznych i zewnętrznych. Im większe jest ich natężenie, tym większe jest prawdopodobieństwo pojawienia się określonego wyniku działania - sukcesu lub porażki. Rekonstruując potoczne spostrzeganie przyczyn zachowania, Heider wyodrębnił siłę osobistą (czynniki wewnętrzne), na którą składają się:

a) zdolności i moc dążenia do celu: przyczyny względnie stałe, działające iloczynowo (pomnażające się) i kompensujące się pod warunkiem, że występują choćby w minimalnym natężeniu;

b) motywacja i intencja: przyczyny względnie zmienne i kontrolowalne.

Siła osobista jest odpowiedzialna za sukces wówczas, gdy człowiek wykorzystuje swoje zdolności w działaniu i jest silnie zmotywowany do wykonania określonego zadania i osiągnięcia zamierzonego celu. Za niepowodzenie są natomiast odpowiedzialne: niski poziom zdolności i motywacji oraz wytrwałości w działaniu.

Nie miatem motywacji, by dążý do warunkowego zwolnienia, ani wiedzy, by to osiagnać. Próbowatem się zmienić, ale brak mi wiary w pozytywny skutek pracy nad soba, a poza tym to, co zaczne, to zaraz rzucam, bo zawsze to jest jakiś wysitek, a ja nie lubię się męczyć. Babcia mi mówiła, ż ja to jestem chlopak, który zapala się szybko do roboty jak stoma, ale szybko gaśnie. Tak wtaśnie mi mówiła. Mąra była i miała rację... [B.T. 45 lat, rozwiedziony, wykształcenie średnie, recydywista siedmiokrotny, wyroki skazujące za kradzieże]

Z kolei wyznacznikami sil środowiskowych (czynniki zewnętrzne) uczynił Heider: „trudności związane z wykonaniem zadania (czynnik względnie stały) oraz przypadek (czynnik zmienny)”. Siły środowiskowe wpływają na zachowanie 
człowieka w ten sposób, że sukces zapewniają mu czynniki związane z łatwością wykonania zadania i szczęście, zaś porażkę generują trudności w działaniu i pech.

Po odbyciu pierwszego wyroku wrócitem do domu - mieszkałem u rodziców i pracowatem z ojcem na budowie (ojciec miat własna działalność gospodarcza). Któregoś razu, na dyskotece wdatem się w bójkę i przez przypadek zabilem czlowieka. Opanowat mnie taki strach przed odpowiedzialnościa, że uciekłem i nawet dość dlugo krytem się przed policja. Wpadtem, bo jestem pechowy - zmienitem wyglad, zapuścitem wasy i brode, ufarbowatem sobie włosy, no wie Pani, tak jak robia na filmach (śmiech), a i tak ktoś mnie rozpoznat i dał znać na komendę. Stąd taki wyrok. Mnie to zawsze wiatr w oczy wieje... [J.K.-40 lat, rozwiedziony, wykształcenie zawodowe, recydywista jednokrotny, wyroki skazujące za kradzież oraz zabójstwo]

Zdaniem Heidera, między motywacją i zdolnością (mocą) istnieje sprawcza, multiplikatywna relacja, co oznacza, że jeśli człowiek nie posiada jakichkolwiek zdolności lub nie wykazuje starań ukierunkowanych na wykonanie danego zadania, to jego wynik jest zerowy. Związek addytywny pojawia się natomiast między efektywną siłą wewnętrzną danej osoby (zdolności + motywacja) a efektywną siłą środowiskową (trudności + przypadek). Tak więc, jeżeli siła osoby wynosi zero, to nie oznacza, że wynik działania także będzie zerowy. Przysłowiowym języczkiem u wagi będzie tu przypadek — szczęście zapewni sukces, zaś pech da porażkę.

Po zakończeniu odsiadki niczego nie potrzebowatem, miatem wsparcie od rodziny. Nie oczekiwatem od nikogo pomocy. Wrócitem do prowadzenia wtasnego serwisu samochodowego, bo mam odpowiednie wyksztatcenie, a i chęci mi nie brakowato, bo stęskniłem się za ta robota. Kumple ciagle mnie nachodzili i proponowali prace zwiąane z legalizacja samochodów, maszyn, traktorów, koparek, no wie Pani, o czym mówię. Dało mi to możliwość zarobienia dużych pieniędzy, ale pewnego dnia miatem pecha - ktoś mnie wsypat $i$ znów tu jestem... [D.L. — 51 lat, rozwiedziony, wykształcenie wyższe, recydywista jednokrotny, wyroki skazujące za oszustwo]

Heider wprowadził także następne dwa pojęcia — „możności” oraz „usiłowania". Pierwsze łączy wpływ zdolności i sil zewnętrznych - możność jest niekontrolowalna i jest tym większa, im bardziej zdolności danej osoby przewyższają trudności generowane przez siły zewnętrzne. Taką osobę postrzega się wówczas jako silną i dającą sobie radę w każdej trudnej sytuacji. Drugie pojęcie - „usiłowanie” - jest kontrolowane przez człowieka i łączy w sobie intencję (chcę wykonać zadanie) i wysilek (staram się wykonać zadanie).

W potocznej analizie zachowania oba te czynniki występują łącznie, definiując kategorię odpowiedzialności osobistej za wynik danego zachowania/działania. Przypisywana jest ona człowiekowi wówczas, gdy pojawienie się u niego choćby niewielkiej „możności” (zdolność/kompetencja + wsparcie zewnętrzne), 
wygeneruje „usiłowanie”, czyli będzie się starał wykonać zadanie z własnej nieprzymuszonej woli.

Do kategorii odpowiedzialności osobistej za wynik zachowania nawiązują współczesne koncepcje resocjalizacji i wspomagania readaptacyjnego. Wszystkie one podkreślają rolę mocy środowiskowych w procesie wspomagania społecznego o charakterze resocjalizacyjno-terapeutycznym. Ale za efekty readaptacji społecznej współodpowiedzialni są przede wszystkim byli więźniowie. To oni muszą chcieć konstruktywnie budować własne życie na wolności oraz aktywnie uczestniczyć w działaniach środowiskowych prowadzących ich do zmiany zgodnej z oczekiwaniami społecznymi. W uznaniu prawa człowieka do rozwoju osobistego oraz udzielaniu resocjalizowanym podmiotom (jednostkom i ich rodzinom) wsparcia kompetencyjnego oraz pomocy w zakresie opieki, wychowania resocjalizującego i terapii, tkwi bowiem sens resocjalizacji, readaptacji i finalnie - reintegracji społecznej [Nowak 2011; Bałandynowicz 2019].

Jednym z kluczowych elementów skutecznej reintegracji ekswięźniów jest ich wspomaganie w środowisku życia oraz ich rodzin, dzięki uruchomieniu sieci lokalnego wsparcia społecznego. Równie ważne jest monitorowanie ich losów oraz wspomaganie w sytuacjach kryzysowych, poprzez łączne podejmowanie środowiskowych działań instytucjonalnych oraz inicjatyw wynikających z celów i zadań organizacji pozarządowych [Ambrozik 2016; Nowak 2016, 2017]. Tak być powinno, ale przyczyny własnej porażki readaptacyjnej recydywiści często dostrzegają w układzie przyczynowo-skutkowym, przerzucającym na innych własną odpowiedzialność za niepowodzenie. Winni są ludzie, system lub środowisko, które $w$ ich przekonaniu nie ułatwia im ponownego wpasowania się w życie społeczne, a często odrzuca.

Za każdym razem, gdy wychodziłem z więzienia, to potrzebowatem pracy, bo najważniejsze to mieć jakieś pieniadze na utrzymanie. Oczekiwałem wsparcia i pomocy przy załatwianiu różnych spraw w urzędach. Wiadomo, lata $w$ więzieniu robia swoje $i$ człowiek jest zagubiony $i$ skazany na pomoc bliskich. A co ma zrobić, gdy rodziny brak, domu brak (albo nie chce wrócić do dawnego środowiska, do starych kumpli), a do tego nie ma uprawnien do korzystania z pomocy społecznej? Pobyt w noclegowniach, schroniskach czy hostelach nie rozwiazuje problemu, bo sa tam ludzie z marginesu, uzależnieni i tacy jak ja. Proszę Pani, przy wieloletnich wyrokach nie istnieje u nas realny system pomocy skazanym po wyjściu na wolność. Na papierze owszem, może..., ale tak naprawdę ludzie opuszczaja więzienia oderwani od rzeczywistości. [H.J. - 37 lat, kawaler, wykształcenie zawodowe, recydywista trzykrotny, wyroki skazujące za kradzieże]

Fundamentalna zasada atrybucji przyczynowej wynikająca z kanonu jedynej różnicy Johna Stuarta Milla określa, że za skutek zachowania człowieka odpowiedzialna jest ta przyczyna, która z tym zachowaniem współwystępuje [np. osobnik X został skazany na karę izolacji więziennej (skutek), gdyż 
popełnił morderstwo (przyczyna)] i nie występuje w sytuacji nieobecności skutku [np. osobnik Y nie został skazany (brak skutku), gdyż albo to nie on zabił, albo nie został wskazany jako sprawca (brak przyczyny)]. Taka konstatacja umożliwia dokonywanie obserwacji wielokrotnych w różnych warunkach. Mogą być one prowadzone w sytuacji zaistnienia skutku (skazanie na karę więzienia) lub jego niezaistnienia (brak skazania).

Wnioski wypływające z potocznej analizy działania ludzkiego sprowadzają się do przekonania, że jeśli znamy wynik zachowania człowieka i natężenie jednej z jego osobowych przyczyn (np. motywacji), to jesteśmy w stanie wnioskować o drugim czynniku osobowym — jego wysiłku włożonym w działanie. Duże wydatkowanie energii w realizację określonego zadania może zatem świadczyć o mniejszej zdolności danej osoby do jego wykonania. Na przykład: po wyjściu na wolność osobnik X przez dłuższy czas intensywnie poszukuje pracy, ale jego wysiłki nie są skuteczne. W tym przypadku możemy przypuszczać, że pomimo silnej motywacji (na co może wskazywać intensywność i czas poszukiwań) nie posiada on kwalifikacji zawodowych odpowiednich do wybranych przez siebie ofert pracy, nie jest w stanie wiarygodnie się zaprezentować w trakcie rozmowy rekrutacyjnej, albo nie wykorzystuje w swoich poszukiwaniach narzędzi cyfrowych, bo nie ma do tego odpowiednich kompetencji, albo nie korzysta z instytucjonalnego pośrednictwa pracy. Można się doszukiwać jeszcze innych przyczyn, między innymi braku zdolności osobnika $\mathrm{X}$ do osiągnięcia założonego przez niego celu, czyli podjęcia pracy. Oznacza to, że jeżeli znana jest trudność zadania oraz zdolność osoby, która to zadanie wykonała, to możemy wnioskować o natężeniu/sile jej starań w realizację zadania.

\subsubsection{Teoria odpowiednich wniosków Edwarda Jonesa i Keitha Davisa}

Opublikowana w 1965 roku teoria wniosków korespondentnych (correspondent inference theory) bazuje na koncepcji F. Heidera i odnosi się do wnioskowania o cechach i predyspozycjach człowieka na podstawie podejmowanych przez niego działań [Jones, Davis 1965]. Zdaniem jej Autorów zachowanie może być wyjaśniane przez poszukiwanie korespondencji, czyli odpowiedniości pomiędzy działaniem, intencją oraz cechami osobowości osoby obserwowanej. Wnioskowanie korespondentne umożliwia nie tylko zrozumienie przyczyn zaobserwowanego u jednostki zachowania, ale także przewidywanie przyszłych jej zachowań. Jednak wnioskowanie wymaga na wstępie dokonania rozstrzygnięcia, czy zachowanie danej osoby było intencjonalne, a jeżeli tak, to co było celem działania. Należy podkreślić, że działanie uznawane jest za intencjonalne, jeżeli dana osoba była/jest świadoma jego skutków oraz gdy działała w warunkach swobody umożliwiających ich zaistnienie.

W myśl założeń teorii wniosków korespondentnych wnioskowanie o treści intencji osoby obserwowanej jest wyprowadzane $\mathrm{z}$ analizy efektów różnych jej działań oraz ich zgodności lub niezgodności z oczekiwaniami. Na przykład: zakładamy, że człowiek, który wiele lat przebywał w warunkach izolacji 
więziennej, po zakończeniu kary będzie poszukiwał środowiska społecznego skłaniającego go do zachowania się w sposób aprobowany społecznie, gwarantującego mu utrzymanie odzyskanej wolności. Idąc tym tropem, w odniesieniu do recydywisty możemy przypuszczać, że:

a) albo nie został on zresocjalizowany $w$ trakcie pobytu w więzieniu i na wolności poszukiwal środowiska społecznego zapewniającego mu podejmowanie dalszych działań przestępczych;

Gdy drugi raz wyszedtem z więzienia, to na taksówce jeździłem, ale to nudne byto... brakowato mi tej - wie Pani - adrenaliny, no to zaczałem myśleć, co by tu zrobić. Odświeżyłem stare kontakty i znalazł się taki jeden kolega (śmiech). I on mówi „chodź ze mna, to zrobimy z jeden, dwa klawisze". Poszedtem na to, bo jeszcze partnerka mi ciagle zawracała głowe „,daj mi pieniadze”, a to, a tamto. No to wymyśliliśmy skok, potem zrobiliśmy drugi i zarobiliśmy nie najgorzej. Żyliśmy z przytupem, ale po pewnym czasie myślę sobie, , a może pójdę, zrobię sobie jeszcze jedna robotę, co mi szkodzi", no bo zachtysnątem się kasa. I poszliśmy z kumplem na tę trzecia robote, a on mnie sprzedat. To i siedze teraz (śmiech), i tak to wyglada. [P.S. - 35 lat, rozwiedziony, wykształcenie podstawowe, recydywista jednokrotny, wyroki skazujące za kradzież oraz rozbój]

b) albo zostal zresocjalizowany pomyślnie, ale nie miał po wyjściu z więzienia warunków do tego, by spełnić oczekiwania społeczne, czyli postępować zgodnie z zasadami życia społecznego;

Po wyjściu z więzienia pierwszy raz powiedziałem sobie, że już tam nigdy nie wrócę. Zrozumiałem wiele rzeczy, wyszedtem z uzależnienia (wcześniej ćpałem), zakochatem się z wzajemnościa i miatem nadzieje, że teraz już będę obywatelem petna gęba... Zaczałem szukać pracy, ale zdarzała się tylko na lewo robota, bo przeciez siedziałem i nikt nie chciat mnie formalnie zatrudnić... Starczało nam na podstawowe rzeczy i jakoś to by byto, ale moja dziewczyna chciała żyć jak księżniczka. Kochatem ja, więc zaczatem szukać dawnych kumpli i po pewnym czasie zajątem się dilerką... Sam nie brałem, bo chciatem żyć normalnie, ale po pewnym czasie wpadtem... A teraz niech Pani popatrzy na mnie - na twarzy jakiś rumieniec mam, pokrzywka czy coś, do lekarza nie chca mnie wziać. Kilka lat temu miałem wypadek i coś mi się stało z kolanem, że ledwo chodzę. Zapalenie stawów mam i nikt mnie nie weźmie do pracy fizycznej. A naukowcem nie jestem. Jak dosiedzę do końca wyroku, to będę szukat jakiś dorywczych prac, ale watpię, że jakieś znajdę... Spłacić alimenty będzie ciężko... Ja tego nie widzę. Mam nawet depresję.. No bo co ja mam zrobić? [N.D. — 42 lata, kawaler, wykształcenie podstawowe, recydywista jednokrotny, wyroki skazujące za kradzieże z włamaniem oraz za handel narkotykami i rozboje]

c) albo nie został zresocjalizowany, gdyż wykazuje rys psychopatyczny. 
Pewność wyprowadzonych wniosków korespondentnych zależna jest od ograniczeń sytuacyjnych w zakresie swobody działania (np. słabnie w sytuacji uwięzienia osoby badanej) lub narzucenia pełnionej roli (np. słabnie w przypadku roli skazanego). Sprawia to, że pojawiają się problemy interpretacyjne dotyczące samoopisu osób badanych przebywających w warunkach izolacyjnych. W sytuacji uwięzienia wnioski korespondentne mogą zostać zdeformowane poprzez manipulacyjne działania osadzonych, silną skłonność do kłamstwa lub też pragnienie przedstawienia siebie w jak najlepszym świetle.

Autorzy teorii wniosków korespondentnych podkreślają możliwość zaistnienia zarówno poznawczego zniekształcenia atrybucji, jak i przecenienia roli czynników wewnętrznych (,,siedzi w więzieniu, bo to zły człowiek”) oraz motywacyjnych (,ukradł, bo nie chciało mu się pracować"). Prawdopodobieństwo uznania czynników wewnętrznych za przyczynę zachowania jest tym większe, im działania danego człowieka mają silne negatywne skutki społeczne oraz gdy odnoszą się do osoby obserwatora (skażenie atrybucji subiektywizmem).

\subsubsection{Model atrybucji przyczynowej Bernarda Weinera}

Dla podjętych w książce rozważań istotna jest przede wszystkim koncepcja Bernarda Weinera [1979 i 1986], odnosząca się do spostrzegania przyczyn sukcesów i porażek (własnych lub cudzych). Weiner zakładał, że obserwatorzy rzeczywistości społecznej rozpatrują wszystkie możliwe typy przyczyn zachowania, ale decyzję o głównej roli jednej z nich podejmują najczęściej na podstawie pozyskanych informacji oraz porównania zachowania danej osoby z zachowaniami innych osób. Po osiągnięciu przez nią sukcesu lub porażki zadają sobie bowiem pytanie o ich źródła. Dokonana atrybucja wpływa na ich myślenie, emocje i zachowanie, determinując $\mathrm{w}$ ten sposób także przyszłe oczekiwanie osiągnięć.

Wyjaśnienia przyczynowe osiągnięć zostały podzielone przez Weinera na wewnętrzne (zdolności i wysiłek) oraz zewnętrzne (przypadek i trudność zadania). Oprócz wymiaru atrybucyjnego odnoszącego się do umiejscowienia przyczyn, Weiner wyodrębnił również wymiar określany jako „stabilnośćzmienność". Należy jednak podkreślić, że wymiar umiejscowienia obecny jest również w teoriach nienawiązujących bezpośrednio do teorii atrybucji, na przykład w teorii społecznego uczenia się Juliana Rottera [1966, 1975]. Liczne badania oparte na tej teorii wskazują na dominację przekonań powiązanych z czynnikami wewnętrznymi, które są znacznie bardziej przystosowawcze niż atrybucje zewnętrzne. Okazuje się bowiem, że osoby dokonujące atrybucji wewnętrznych znacznie lepiej radzą sobie w sytuacjach trudnych, łatwiej nawiązują relacje społeczne oraz są sprawniejsze w wykonywaniu zadań, zwłaszcza poznawczych. Badania Radosława Łukasza Drwala [1979], Ewy Drozdy-Senkowskiej [1982] i Piotra Gasparskiego [1979; 1989; 1997] wykazały, że osoby upatrujące przyczyn zachowania w czynnikach wewnętrznych są lepiej przystosowane społecznie niż osoby dokonujące atrybucji zewnętrznych. Lepiej radzą sobie ze stresem, rzadziej miewają stany lękowe i epizody depresyjne, 
są bardziej spostrzegawcze i sprawcze oraz zainteresowane tym, co się dzieje w przestrzeni społecznej.

Na dokonywanie atrybucji przyczynowych wpływ mają także czynniki stałe i zmienne. Są one istotne w kształtowaniu się obu rodzajów atrybucji (wewnętrznych i zewnętrznych). Weiner utworzył z nich swoistą matrycę czynników, pomocną $\mathrm{w}$ wyłanianiu sposobów wyjaśniania sukcesów i porażek. W ten sposób powstał model zawierający cztery $(2 \times 2)$ kategorie sądów atrybucyjnych:

a) atrybucje wewnętrzne - czynniki stałe: wysiłek typowy i zdolności; czynniki zmienne: wysiłek czasowy i nastrój;

b) atrybucje zewnętrzne - czynniki stałe: opinia osoby oceniającej i trudność zadania; czynniki zmienne: nietypowa pomoc i pech/szczęście.

W efekcie dalszych badań model Weinera został poszerzony przez Roberta Rosenbauma [za: Försteling 2005], który dodał trzeci wymiar - kontrolowalność, która odpowiada za reakcje afektywne i jest opisywana trzema elementami: intencjonalnością, odpowiedzialnością i możliwością kontrolowania własnych zachowań. W nowym modelu wyodrębniono zatem osiem $(2 \times 2 \times 2)$ kategorii sądów atrybucyjnych (schemat 1).

\begin{tabular}{|c|c|c|c|c|}
\hline \multirow{2}{*}{ Intencjonalność } & \multicolumn{2}{|c|}{ Atrybucje wewnętrzne } & \multicolumn{2}{|c|}{ Atrybucje zewnętrzne } \\
\hline & stałe & zmienne & stałe & zmienne \\
\hline $\begin{array}{l}\text { Poza kontrolą } \\
\text { intencjonalną }\end{array}$ & zdolności & nastrój & $\begin{array}{c}\text { trudność } \\
\text { zadania }\end{array}$ & pech/szczęście \\
\hline $\begin{array}{l}\text { Pod kontrolą } \\
\text { intencjonalną }\end{array}$ & $\begin{array}{l}\text { typowy } \\
\text { wysiłek }\end{array}$ & $\begin{array}{l}\text { czasowy } \\
\text { wysiłek }\end{array}$ & $\begin{array}{c}\text { ingerencja } \\
\text { (pomoc) } \\
\text { instytucjonalna }\end{array}$ & $\begin{array}{l}\text { nieoczekiwana } \\
\text { ingerencja } \\
\text { (pomoc) innych }\end{array}$ \\
\hline
\end{tabular}

Schemat 1. Klasyfikacja atrybucji oparta na wymiarach intencjonalności, umiejscowienia i stabilności

Źródło: opracowanie własne na podstawie: F. Försterling (2005). Atrybucje. Podstawowe teorie, badania i zastosowanie. Gdańsk: GWP.

Zdaniem Weinera rodzaj atrybucji determinuje oczekiwania co do przyszłości, o czym świadczy historia życia każdego człowieka opisująca jego dokonania w kategoriach sukcesów i porażek. Oczekiwania co do wyniku zamierzonych działań są powiązane nie tylko z efektami przeszłych dokonań, ale w dużym stopniu są determinowane stałością atrybucji przyczynowych [Heckhausen i in., 1985]. I tak, jeżeli sukces wyjaśniany jest atrybucją wewnętrzną i przypisany jest zdolnościom lub typowemu wysiłkowi, to można oczekiwać wysokiego prawdopodobieństwa jego powtórzenia. Jeżeli natomiast przyczyny sukcesu lokowane są w czynnikach zmiennych (czasowy wysiłek lub nastrój), to należy się liczyć 
z niewielkim prawdopodobieństwem jego wystąpienia w przyszłości. W przypadku sukcesu powiązanego z czynnikami wewnętrznymi, gdy odnotowano krzyżowy wynik obserwacji, należy dokonać rozstrzygnięcia pomiędzy czynnikiem stałym (zdolności) i zmiennym (wysiłek czasowy lub nastrój). Oznacza to konieczność powtórzenia badania i zestawienia obu wyników. W przypadku uzyskania wyniku zgodnego z poprzednim można wysnuć wniosek, że sukces jest efektem dyspozycji posiadanych przez osobę badaną.

Odnosząc powyższe do problemu recydywy, należy podkreślić, że praca resocjalizacyjna i przygotowanie skazanych do samodzielnego radzenia sobie po wyjściu na wolność powinny być prowadzone jeszcze $\mathrm{w}$ trakcie pobytu skazanych w zakładzie karnym, z ukierunkowaniem na kształtowanie poczucia skuteczności własnej w zakresie konstruktywnego, akceptowanego społecznie przystosowania do życia społecznego. Tylko w ten sposób, poprzez odpowiednie wzmocnienie kompetencyjne oraz wyposażenie osadzonych w umiejętności samodzielnego radzenia sobie z problemami, można zapobiegać bezradności i postawom roszczeniowym osób opuszczających zakłady karne oraz zapobiegać ich zachowaniom ryzykownym i patologicznym.

Po wyjściu na wolność pogubiłem się, bo po kolejnej, tym razem prawie 10-letniej odsiadce wrócitem do świata, którego nie mogłem nijak rozpoznać. Wszystko byto inne, nawet $w$ autobusie nie wiedziatem, gdzie się $\mathrm{ka}$ suje bilet, a na dworcu kolejowym to już kręćka jakiegoś dostałem. Rodzina mi się posypała, więc nie miatem nawet, gdzie spać, kasy tė̇ starczyło tylko na dojazd do dalekiego kuzyna, z którym wcześniej się kumplowałem. Dat mi tydzień na poradzenie sobie i co ja miałem zrobić — mieścina jakaś zapadta, wokót obcy ludzie... A jak już dowiedzieli się, że siedziatem kilka razy, to nawet ze mna gadać nie chcieli, gdy szukałem jakiejś pracy, a ja dobry stolarz jestem, lubię dtubać $w$ drewnie i sprytnie mi to wychodzi. Ale nic z tego, no i poszedtem znów na całość... Wie Pani, zaczątem robić to, co umiałem - kradtem w sklepach i na życie byto, aż wtamatem się do jakiegoś mieszkania i znów mnie psy dorwaty... [W.N. - 51 lat, rozwiedziony, wykształcenie zawodowe, recydywista dwukrotny, wyroki skazujące za kradzieże; rozbój przy użyciu niebezpiecznego narzędzia; kradzież $\mathrm{z}$ włamaniem]

Ogólnie rzecz ujmując, Weiner dowiódł, że spostrzegana stałość przyczyn minionego zdarzenia wpływa na zmiany w oczekiwaniu sukcesu zachodzące po uzyskaniu wyniku. Istotne jest przy tym to, że pośredniczący wpływ atrybucji stałych i zmiennych nie jest powiązany z wymiarem umiejscowienia kontroli [1986]. Osoby przypisujące własne porażki zmiennym czynnikom zewnętrznym (np. przypadek) lub wewnętrznym (niewielki wysiłek włożony w wykonanie zadania) mają mniejsze oczekiwania sukcesu niż osoby odwołujące się do stałych czynników wewnętrznych (np. niewystarczające zdolności) lub zewnętrznych (np. trudność zadania). 
Według Weinera stałość atrybucji zwiększa także nasilenie reakcji emocjonalnych towarzyszących sukcesowi lub porażce. Nie jest to jednak zależne od umiejscowienia przyczyn zachowania i kontrolowalności. Na przykład przy atrybucji zewnętrznej kontrolowalność przyczyny porażki w postaci opinii osoby oceniającej, aktywuje wobec niej emocje negatywne. Zaobserwowano także, że silniejsze stany afektywne, takie jak wstyd, gniew czy poczucie bezradności, pojawiają się w przypadku dokonywania atrybucji zewnętrznych.

W badaniu opartym na modelach zachowania altruistycznego i agresywnego Weinera dowiedziono, że atrybucje zachowania odbiegającego od normy, w tym dewiacyjnego, zaliczane do czynników kontrolowalnych (np. nieodpowiedzialność, brak zdyscyplinowania), wywołują u obserwatorów emocje negatywne i niechęć do niesienia pomocy osobom dotkniętym ,innością”. W większym też stopniu wpływają na ich odrzucenie społeczne w porównaniu z atrybucjami opartymi na czynnikach stałych, niekontrolowalnych [Juvonen 1991]. Dzieje się tak, gdyż ludzie spostrzegają osoby od nich odmienne jako odpowiedzialne za własne negatywne zachowania oraz obarczają je winą za wzbudzanie u nich przykrych emocji, takich jak lęk, gniew czy wstręt. Potwierdzają to wyniki innych badań, które wskazują, że atrybucje środowiskowe dokonywane na bazie czynników kontrolowalnych (np. bieda), częściej skłaniają ludzi do udzielania wsparcia i pomocy społecznej [Weiner 1995]. Podobnie jest z czynami przestępczymi [Feather 1996]. Jeżeli ludzie uznają odpowiedzialność własną danej osoby za popełnione przez nią przestępstwo (czynnik kontrolowalny), to wówczas zostanie ono uznane za poważne, niezależnie od tego, czy była to kradzież, pobicie, czy niedostosowanie się do zasad ruchu drogowego. Atrybucje zewnętrzne wyjaśniające zdarzenia negatywne (np. ubóstwo, bezrobocie) czynnikami kontrolowalnymi (np. lenistwo, niepunktualność) prowadzą do obarczenia winą osoby dotkniętej tym zdarzeniem, blokują pozytywne reakcje wobec niej oraz skłaniają do jej krytykowania czy wręcz ukarania.

Jeżeli przewidywanie i/lub kontrolowanie zachowań danej osoby jest dla innych ważne, to poszukiwanie przyczyn jej postępowania zwiększa ich skłonność do poszukiwania wyjaśnienia w czynnikach dyspozycyjnych — zdolnościach, predyspozycjach, talentach i innych jej przymiotach. Stąd też atrybucje wewnętrzne są dominujące w przypadku, gdy przewidywanie i/lub kontrolowanie zachowania innych jest dla ludzi ważne i uruchomione oczekiwaniem konkretnego wyniku czy też określonych interakcji [Miller, Norman, Wright 1979; Robins, Spranca, Mendelhson 1996]. Jest to niewątpliwie pułapka dla niewprawnych badaczy, gdyż indywidualne narracje pozyskane podczas wywiadów mogą zostać zainfekowane manipulacjami, których źródłem są właśnie czynniki dyspozycyjne.

Konstatując, implikacją braku konsensusu między badaczami tego zjawiska co do jego istoty i mechanizmów, które je uruchamiają, są dalsze eksploracje empiryczne. 


\subsubsection{Model współzmienności Harolda Kelleya}

Teoria Kelleya stanowi zdaniem Gerda Gigerenzera [1991] nową koncepcję umysłu ludzkiego jako intuicyjnej statystyki oraz jest przykładem teorii poznawczej zainspirowanej przez nowe narzędzia analizy danych. Kelley podtrzymał stanowisko Heidera dotyczące podobnego wnioskowania przyczyn zdarzeń przez ludzi nauki i laików oraz stosowania przez nich tych samych metod. Twierdził on, że umysł ludzki przypisuje przyczynę zdarzenia danemu skutkowi w taki sam sposób, w jaki współcześni naukowcy zajmują się analizą zachowań (wykonanie ANOVA i testowanie hipotez zerowych). Stąd też pomysł Kelleya, by zastosować analizę wariancji do zbudowania teorii wyjaśniającej konstruowanie atrybucji przyczynowych przez laików. W tym celu zmodyfikował on zasadę określania atrybucji wyprowadzoną przez Heidera z kanonu jedynej różnicy Milla. Nadał jej miano „zasady współzmienności” i opisał w postaci modelu ANOVA. Wyodrębnił w nim trzy klasy czynników wyjaśniających zaistniałe zdarzenia: stałe cechy osoby, stałe obiektu i przemijające okoliczności oraz wprowadził podział na czynniki przyczynowe osobowe (wewnętrzne) oraz przedmiotowe (zewnętrzne). Wybór czynnika (osoba, obiekt lub okoliczności) zależny jest od tego, z którą przyczyną (zmienna niezależna) dany skutek (zmienna zależna) jest współzmienny. Przy dokonywaniu atrybucji przyczynowych powinny być brane pod uwagę trzy kategorie informacji [Kelley 1973, s. 110]:

a) wybiórczość (informacje o współzmienności obiektów i skutków) — jest ona niewielka, gdy między obiektem i skutkiem brakuje współzmienności skutek jest zawsze taki sam, niezależnie od obiektu (np. gdy człowiek ponosi porażkę we wszystkich podejmowanych przez siebie działaniach), zaś duża w przypadku istnienia współzmienności — skutek zmienia się wraz z obiektem (np. człowiek ponosi porażkę tylko w jednym działaniu);

b) powszechność (informacje o współzmienności skutku z osobami) — jest ona niewielka, gdy zmiana osoby wiąże się ze zmianą skutku (np. jedna osoba doznaje porażki przy wykonaniu określnego zadania, a pozostałe odnoszą sukces), natomiast $\mathrm{z}$ dużą powszechnością mamy do czynienia wówczas, gdy zmiana osoby nie wywołuje zmiany skutku (np. wszystkie osoby wykonujące dane zadanie odnoszą sukces);

c) spójność (informacje o współwystępowaniu przyczyn i skutków) — jest ona wysoka, gdy zawsze wraz z przyczyną (osobą, obiektem) pojawia się skutek, zaś niska, gdy czasem skutek występuje przy braku przyczyny lub wraz z nią się nie pojawia.

Do atrybucji skutku powinny z kolei prowadzić następujące (idealne) układy współzmienności:

a) atrybucja do osoby - mała powszechność (np. dana osoba ponosi porażkę w działaniu, w którym wszystkie inne osoby odnoszą sukces) i mała wybiórczość (np. w każdym działaniu dana osoba odnosi porażkę), duża spójność (np. wszystkie usiłowania danej osoby skutkują porażką); 
b) atrybucja do obiektu - duża powszechność (dane działanie zapewnia sukces wszystkim osobom), duża wybiórczość (tylko jedno działanie skutkuje porażką, inne zapewniają sukces) i duża spójność (dane działanie zawsze prowadzi do porażki);

c) atrybucja do okoliczności - mała powszechność (np. w danych okolicznościach osoba doznaje porażki, podczas gdy w innych odnosi sukces), duża wybiórczość (np. tylko jedne okoliczności zapewniają danej osobie sukces, w innych doznaje ona porażki), mała spójność (np. w określonych okolicznościach czasem pojawia się sukces).

Ponieważ zarówno kanon jedynej różnicy Milla, jak i zasada współzmienności stanowią, że skutek jest przypisywany tej przyczynie, z którą on współzmienia się w czasie, to aby dokonać atrybucji do osoby lub obiektu, należy przeprowadzić wielokrotne obserwacje w różnym czasie [por. Meyer, Försterling 1993]. Jak już wcześniej wspomniano, wnioskowanie o przyczynach zachowań osób badanych na podstawie samoopisu czy jednorazowej obserwacji może być obarczone poważnym błędem. Wielokrotność obserwacji podnosi zatem rzetelność uzyskiwanych informacji, a tym samym wzmacnia trafność (wewnętrzną i zewnętrzną) uzyskanych wyników.

W badaniach prowadzonych na podstawie strategii jakościowej, wykonanie wielokrotnych obserwacji jest obwarowane warunkami, w których odbywa się badanie oraz dostępnością do osób badanych. Dotyczy to zwłaszcza badań w zakresie penitencjarystyki, głównie z uwagi na specyficzny i trudny przedmiot i podmiot badania oraz regulacje prawne. Warunki i okoliczności badania osób odbywających karę pozbawienia wolności, a zwłaszcza recydywistów, nie sprzyjają nawiązaniu właściwej relacji i wytworzeniu atmosfery skłaniającej do szczerych wypowiedzi. Dużym utrudnieniem w pozyskaniu rzetelnych informacji są sami osadzeni, którzy posiadają cechy i motywacje utrudniające lub blokujące dotarcie do faktów. Ponadto dostęp badacza spoza kadry penitencjarnej do osób badanych jest zwykle jednorazowy i ograniczony w czasie, a w związku z tym niewystarczający i w niewielkim stopniu uprawniający do szerokich generalizacji uzyskanych wyników.

Biorąc to pod uwagę, badania nad przyczynami porażki readaptacyjnej w narracji recydywistów penitencjarnych, prezentowane w dalszej części książki, zostały zaprojektowane tak, by atrybucje przyczynowe dokonywane w schemacie retrospektywnym (strategia jakościowa-wywiady narracyjne, pogłębione, swobodne), były analizowane na kanwie modelu atrybucji przyczynowych B. Weinera. 


\subsection{Deformacje atrybucyjne}

W wielu badaniach zainspirowanych teoriami atrybucji przyczynowych odnotowano liczne błędy procesu atrybucji [Wojciszke 2006]. Problem dotyczy zarówno niezgodności dokonywanych atrybucji z ich racjonalnymi modelami, jak i mechanizmów prowadzących do tego rodzaju anomalii. Okazało się bowiem, że przyczyny zdarzeń, zachowań czy działań nie są postrzegane przez ludzi adekwatnie do teorii wniosków korespondentnych, koncepcji współzmienności Kelleya czy innych modeli atrybucji, które zakładają, że atrybucje są determinowane informacjami, a nie skutkiem działania (sukces lub porażka), emocjami (pozytywne lub negatywne), czy też motywacjami (waga skutku lub znaczenie osobiste).

Odstępstwo oceny przyczyn od przewidywań modelu — jednokierunkowe i systematyczne — określane jest mianem błędu atrybucyjnego. Identyfikacja mechanizmów powodujących tego typu odchylenia wymagała podjęcia licznych eksploracji badawczych. Zostały one zapoczątkowane obserwacją dokonaną podczas badania ukierunkowanego na weryfikację modelu Kelleya, a przeprowadzonego przez McArthura [1977]. Odkryto wówczas, że w procesie atrybucji nie wszystkie przyczyny zachowania są wybierane z takim samym prawdopodobieństwem oraz że istnieje skłonność do przypisywania przyczyn zachowania danej osoby czynnikom wewnętrznym — jej cechom i zdolnościom osobistym, czego model Kelleya nie przewiduje. To odstępstwo określono mianem podstawowego błędu atrybucji [Ross 1977]. Polega on na tym, że ludzie wykazują skłonność do wyjaśniania cudzych zachowań dyspozycjami osobowymi (czynniki wewnętrzne) i pomijania wpływu czynników sytuacyjnych, gdyż obserwując zachowanie, koncentrują się na nim samym i osobie, która je prezentuje, a nie na sytuacji, która je wygenerowała [Kassin, Pryor 1985]. Ludzie wykazują również tendencję do pomijania informacji o powszechności występowania danego zachowania [Nisbett, Borgida 1975]. Najbardziej istotne jest jednak to, że podstawowy błąd atrybucji jest plastyczny i zmniejsza się w sytuacji konieczności wyjaśnienia i uzasadnienia oceny wpływu czynników wewnętrznych na dane zachowanie, gdyż w wielu sytuacjach obserwatorzy nie dysponują rzetelną wiedzą na temat cech osobowościowych, zdolności czy dyspozycji osób obserwowanych, a wnioskują o przyczynach ich zachowania na podstawie supozycji lub atrybutu będącego nośnikiem piętna. Błąd ten dość często popełniają także badacze, gdy skupiają się wyłącznie na analizie opisów zachowań, nie obserwując ich w sytuacjach rzeczywistych, co prowadzi do pomijania kontekstu zdarzenia [Fiske, Taylor 1991].

Podstawowy błąd atrybucji prowadzi także do podbudowy i umocnienia stereotypów i uprzedzeń. Przykładem ilustrującym tę skłonność może być zjawisko polegające na obwinianiu ofiary przestępstwa czy innego, tragicznego w skutkach zdarzenia. Komentując je, obserwatorzy podają argumenty wskazujące na to, że np. osoba poszkodowana, ofiara wypadku komunikacyjnego niepotrzebnie podjęła ryzyko; ofiara porwania nie podjęła kroków w celu uniknięcia zdarzenia; ofiara gwałtu prowokowała gwałciciela lub ofiara przemocy domowej godziła się 
na działanie sprawcy. Takie reakcje mogą pojawiać się wskutek tego, że uprzedzenia generują błędne przekonanie, że ofiary powinny były przewidzieć negatywne skutki przyszłych zdarzeń, a więc powinny postępować tak, by ich uniknąć.

Ważnym spostrzeżeniem jest również to, że ludzie wykazują skłonność do wyjaśniania cudzych zachowań na podstawie ich cech, ale własne zachowania tłumaczą najczęściej wpływem czynników sytuacyjnych. Mechanizm ten jest wyzwalany kilkoma czynnikami występującymi jednocześnie:

1. Ukierunkowanie uwagi [Storms, 1973]: obserwator dokonujący atrybucji przyczynowej skoncentrowany jest na osobie obserwowanej (atrybucja wewnętrzna), zaś ona próbując dojść do przyczyn własnego zachowania, kieruje swoją uwagę na okoliczności zewnętrzne towarzyszące swojej aktywności (atrybucja zewnętrzna). $Z$ odwróceniem atrybucji mamy natomiast do czynienia w sytuacji, gdy człowiek zachowujący się w określony sposób zaczyna siebie obserwować i analizować swoje postępowanie (atrybucja wewnętrzna), zaś obserwator koncentruje się na czynnikach środowiskowych (atrybucja zewnętrzna).

W badaniach własnych, dotyczących przyczyn porażki readaptacyjnej, już na etapie projektowania schematu badawczego założono odwróconą atrybucję - to osoby badane (recydywiści penitencjarni) dokonywały wnioskowania na temat przyczyn własnych, nieskutecznych prób ponownego włączenia się w nurt życia społecznego zgodnego z obowiązującymi normami (atrybucje wewnętrzne). Badacz z kolei koncentrował się na poszukiwaniu przyczyn niepowodzenia readaptacyjnego ekswięźniów, wynikających z działań środowiskowych i systemowych (atrybucje zewnętrzne).

2. Odmienność wiedzy [Nisbet, Caputo i in. 1973]: osoba, której zachowanie jest wyjaśniane, wykazuje większą skłonność do postrzegania zmienności swoich zachowań w konkretnym usytuowaniu zewnętrznym, gdyż posiada na ich temat większą wiedzę niż osoba wyjaśniająca jej zachowanie; z kolei uwaga badacza zostaje przeniesiona na analizę czynników zewnętrznych, gdy zna on osobę badaną — w takiej sytuacji słabnie jego skłonność do dokonywania atrybucji wewnętrznych.

W przypadku przedmiotowego badania odmienność wiedzy badacza i osób badanych jest znaczna, gdyż wynika przede wszystkim z silnie zróżnicowanych poziomów adaptacji do życia społecznego. Badacz posiada wiedzę przedmiotową oraz dysponuje wynikami dotychczasowych badań w zakresie mechanizmów i czynników wewnętrznych uruchamiających zachowania przestępcze osób badanych, co powoduje, iż tylko w niewielkim stopniu odnosi się do cech i dyspozycji osobowościowych osób badanych. Skupia się natomiast na kontekstach środowiskowych i systemowych. Przyznać trzeba, że decyzja o skłonieniu badanych recydywistów do poszukiwania i analizowania przyczyn własnych niepowodzeń readaptacyjnych była dość ryzykowna. Założono jednak, że badanie w takim schemacie zainteresuje recydywistów głównie z uwagi na to, że będą mogli sami dochodzić do przyczyn ich własnej, aktualnej sytuacji życiowej, a w związku z tym będą 
bardziej otwarci i skłonni do retrospektywnych wynurzeń, zaś oddanie im pola badawczego będą traktowali jako swoiste wyróżnienie i przejaw zaufania. Jak się finalnie okazało, przyjęta strategia okazała się słuszna. Z przeprowadzonych wywiadów niekierowanych oraz rozmów prowadzonych w swobodnym tonie wybrzmiewa zadowolenie osób badanych, bo jak sami stwierdzali: „...któż zna mnie lepiej niż ja sam”; ,...nareszcie ktoś mnie wysłuchał” czy „...przemyślałem moje życie i wiem już, że to ja jestem sprawcą swojej niedoli. Prawdę mówiąc, trochę mi ulżyło...".

Zauważono także, że w większości dotychczasowych badań stosowano technikę ankiety z wykorzystaniem kwestionariusza, zaś rzadziej prowadzono badania na podstawie techniki wywiadu swobodnego i bezpośredniego, a jeżeli już, to wywiadu kierowanego lub z użyciem kwestionariusza. Wydaje się to zrozumiałe z uwagi na miejsce pobytu skazanych (zakład karny) i ograniczoną dostępność do jednostek penitencjarnych.

3. Zróżnicowany język opisu zachowań własnych i cudzych [Semin, Fiedler 1991]: zachowania własne opisywane są za pomocą zaimków osobowych połączonych z czasownikami (np. ja zrobiłem), zaś opis cudzych zawiera zwroty bardziej złożone i abstrakcyjne (np. on to zrobił), ukazujące zarówno sens zachowania (np. on to ukradt), jak i cechy osobowości (np. on zrobił to, bo to psychopata).

W takim przypadku może dochodzić do nadinterpretacji lub błędnej interpretacji danych pozyskanych z opisu zachowań dokonanych przez osobę badaną. Dlatego też dużą wartość poznawczą mają dane pochodzące z wywiadów niekierowanych i bezpośrednich, które dają badaczowi szansę na ewentualne doprecyzowanie wypowiedzi osób badanych, obserwację ich stanów emocjonalnych towarzyszących wypowiedziom oraz możliwość wstępnej weryfikacji skłonności do konfabulacji czy kłamstwa. Jest to niezwykle istotne w badaniach dotyczących zachowań dewiacyjnych, w tym przestępczych.

4. Efekt niedoceniania powszechności informacji [Kassin 1979]: model Kelleya zakłada, że wyznacznikami atrybucji przyczynowych są przede wszystkim trzy wymiary informacyjne: powszechność, wybiórczość i spójność oraz, że każdy z nich powinien być w takim samym stopniu brany pod uwagę $\mathrm{w}$ dokonywaniu atrybucji. Jednak okazało się, że informacje o powszechności wyjaśniają znacznie mniej atrybucji niż wybiórczość i spójność.

5. Efekt falszy wej powszechności informacji [Ross, Green, House 1977): ludzie często przeceniają stopień rozpowszechnienia ich własnych postaw i zachowań, co oznacza, że w sytuacji percepcji poglądów i zachowań odmiennych od własnych częściej wyjaśniają je w odniesieniu do atrybucji wewnętrznych, zaś w przypadku zachowań spójnych z prezentowanymi — mają skłonność do atrybucji zewnętrznych. Jest to zjawisko stałe i silne, wyjaśniane skłonnością ludzi do kontaktu i utrzymywania znajomości z osobami mającymi podobne do nich przekonania i zachowania w określonych sytuacjach. Efekt fałszywej powszechności można też tłumaczyć skłonnością ludzi do przenoszenia 
wniosków na całą populację. Stąd też w przypadku zachowań przestępczych i powrotności do przestępstwa występuje duże prawdopodobieństwo wyjaśniania ich $\mathrm{w}$ formie poszukiwania szczególnych cech osobowościowych predestynujących ludzi do tego typu zachowań, w mniejszym zaś stopniu do poszukiwania uwarunkowań zewnętrznych. W ten sposób formowane są uprzedzenia i stereotypy.

6. Egocentryzm atrybucyjny [Ross, Sicoly 1979]: ten błąd odnosi się do tendencji przypisywania sobie większego wkładu w sukces odniesiony przez współdziałanie z innymi osobami. Egocentryzm atrybucyjny jest widoczny między innymi u osób inkarcerowanych za udział w grupach przestępczych, które często opisują (również współwięźniom) swoje doniosłe dokonania w czynach popełnionych wspólnie z innymi, niezależnie od rzeczywistego wkładu własnego.

7. Egotyzm atrybucyjny [Miller, Ross 1975]: jest to tendencja do pozytywnego wyjaśniania własnych zachowań, uruchamiająca mechanizm wzmacniający w przypadku sukcesu i obronny w przypadku porażki. Atrybucja własnego sukcesu generuje afektywne korzyści — wyzwala w człowieku pozytywne emocje oraz wzrost poczucia własnej wartości i samooceny [Fiske, Taylor 1991]. Z kolei wewnętrzna atrybucja porażki prowadzi do afektywnej straty — pojawiają się bowiem emocje negatywne, brak wiary we własne zdolności i znaczne obniżenie samooceny. W ten właśnie sposób wyjaśniana jest skłonność do przypisywania sobie sukcesu (atrybucja wewnętrzna) i obarczania innych winą za własne porażki (atrybucja zewnętrzna). Jest to mechanizm umacniania i ochrony własnego „Ja” [Hastrof, Schneider, Polefka 1970; McFarland, Ross 1982].

Wyniki licznych badań nad umiejscowieniem kontroli u recydywistów [m.in. Bowen, Gilchrist 2004; Bowen, Gilchrist, Beech 2005; Turecka 2005; Terelak, Steckiewicz 2007; Belniak 2014; Nowak 2017] potwierdzają występowanie u większości z nich zewnętrznego poczucia umiejscowienia kontroli, co pośrednio wskazywać może na skłonność do dokonywania atrybucji ukierunkowanych na ochronę własnego „Ja”. Teza ta wymagałaby jednak weryfikacji empirycznej.

Badania wykazały także, że ludzie mogą zauważać zależność pomiędzy własnymi działaniami i odniesionym w ich efekcie sukcesem, ale nie dostrzegać własnego udziału w odniesionej porażce [m.in. Miller, Ross 1975; Pyszczyński, Greenberg 1987; Fletscher, Ward 1988]. Podobnie jest z przyczynowymi atrybucjami odnoszonymi do sukcesów i porażek innych osób [Beckman 1970; Carver 1980]. Przypisywanie sobie większej odpowiedzialności za sukces niż porażkę stwierdzono także w badaniach międzykulturowych [Fletscher, Ward 1988]. Egotyzm atrybucyjny można także wyjaśnić na podstawie tezy, że ludzie podejmują zazwyczaj określone działanie (np. rozwiązanie problemu), gdy upatrują w nim sukcesu, a co więcej, są przekonani o tym, że posiadają odpowiednie ku temu zdolności. W takiej sytuacji porażka jest dla nich niespodziewanym wynikiem działania, gdyż byli oni przekonani o posiadaniu predyspozycji (cechy, umiejętności, zdolności) gwarantujących im osiągnięcie sukcesu. Konsekwencją tego 
jest najczęściej postrzeganie przez nich negatywnego efektu działania (porażki) w kategoriach pecha czy przypadku (atrybucje zewnętrzne).

Reasumując, ludzie z reguły dokonują atrybucji realistycznych, jednak badania w tym zakresie wskazują na błędy popełniane w procesie atrybucji zarówno przez osoby obserwujące, jak i osoby prezentujące określone zachowania. Deformacje atrybucyjne mogą być efektem stronniczości (w rozumieniu skłonności lub tendencji), niezdolności do dokonania racjonalnej oceny (między innymi z uwagi na silną afektywność) oraz motywów ukierunkowanych na ochronę lub wzmocnienie własnego „Ja”. Najnowsze eksploracje badawcze dają podstawy do przyjęcia tezy, że za deformacje atrybucyjne mogą być odpowiedzialni również badacze. Chodzi o to, że w eksperymentach nie zawsze są dostarczane osobom badanym wszystkie informacje mogące wykryć omówione wyżej błędy atrybucyjne [por. Försterling 2005, s. 100-102]. Problemem generującym błędy interpretacyjne są także atrybucje asymetryczne rozpatrywane w świetle odmiennych perspektyw [Storms, 1973]:

- obserwatora, który w poszukiwaniu przyczyn danego zachowania, bardziej koncentruje swoją uwagę na osobie obserwowanej, jej cechach, możliwościach, zdolnościach, niż na zewnętrznych uwarunkowaniach i przebiegu jej aktywności;

- osoby obserwowanej, która w większym stopniu skupia się na okolicznościach, celach i efektach swojego zachowania/działania niż na sobie.

Atrybucje asymetryczne są wyjaśniane nie tylko na podstawie tezy, że atrybucje przyczynowe są przez ludzi konstruowane na bazie dostarczonych im informacji, ale także oszacowanych przez nich korzyści w postaci dostarczenia sobie pozytywnych emocji czy wzrostu poczucia własnej wartości (atrybucje egotystyczne).

W świetle podjętej problematyki istotne wydaje się choćby krótkie omówienie zagadnienia atrybucji międzygrupowych. Odnoszą się one bowiem do postrzegania zachowań i skutków aktywności członków jednej grupy przez członków innej grupy. Chodzi tu o atrybucje przyczynowe dokonywane przez dostosowanych społecznie członków społeczeństwa w obliczu zachowań tej części społeczeństwa, która wchodzi w konflikt z obowiązującym prawem i łamie normy społeczne, ale także o odniesienia do członków grup powszechnie postrzeganych jako ,inne” z uwagi na posiadane przez nie atrybuty (np., rasa, przynależność religijna czy kulturowa).

Gdy grupa własna jest postrzegana jako ważna i powszechnie aprobowana, zaś grupa obca jest dotknięta ,innością”, to atrybucje przyczynowe międzygrupowe (wyjaśnianie takich samych zachowań członków obu grup) mogą być mniej krytyczne dla grupy własnej niż obcej. Tendencyjność atrybucji międzygrupowych wyjaśnia w pewnym stopniu trudności w niwelowaniu antagonistycznych nastawień [m.in. Hewstone, Klink 1994], gdyż wewnętrzne atrybucje zachowań negatywnych i zewnętrzne pozytywnych działań grupy obcej podtrzymują stereotyp jej negatywnego postrzegania. 
Potwierdzają to wyniki licznych badań nad stygmatyzacją społeczną, które ukazują mechanizm naznaczania i wykluczenia społecznego oparty na stereotypowych odniesieniach do ludzi i grup niemieszczących się w zunifikowanych ramach społecznych [m.in. Nowak 2017a; Pospiszyl 2012; Kudlińska 2011; Czykwin 2007]. Wśród nich są więźniowie i ekswięźniowie - grupa powiązana z instytucją totalną, traktowana przez większość społeczną jako gorsza i silnie zagrażająca.

\subsection{Etykiety i stereotypy w procesie przetwarzania informacji i formowania się przekonań}

Piętno — jak wskazuje Goffman [2007] — jest rezultatem powstającego dysonansu poznawczego pomiędzy tożsamością oczekiwaną (wymaganą, normalną, właściwą danej grupie) a tożsamością rzeczywistą jednostki wraz z właściwymi jej cechami i atrybutami, które gdy są niezgodne z oczekiwaniami społecznymi, dyskredytują daną osobę. Stygmat odgrywa „oślepiającą rolę”, wydobywając z wizerunku jednostki jedną negatywną cechę i pomijając cechy inne, często pozytywne [Czywkin 2007].

W odniesieniu do społecznej natury piętna, stygmatyzacja jest procesem poznawczego naznaczania jednostki przez przypisanie jej negatywnego, dyskredytującego atrybutu skłaniającego innych do postrzegania jej przez pryzmat nadanej etykiety [Major, O'Brien 2005; Heatherton i in. 2008]. Powody naznaczania ludzi są różne, ale zasadniczo wyróżniane są trzy rodzaje stygmatu [Goffman 2005]:

- fizyczny, związany z postrzeganiem u innych deformacji fizycznych i trwałych niepełnosprawności ruchowych;

- charakteru, odnoszący się do cech i dyspozycji wewnętrznych człowieka (np. lenistwo, nieopanowanie, nadmierna, często nienaturalna emocjonalność czy ortodoksyjne przekonania) oraz wnioskowanych na podstawie zdarzeń obecnych w biografii jednostki (np. nałogi, pobyt w więzieniu lub zakładzie psychiatrycznym);

- plemienny, różnicujący z uwagi na narodowość, rasę i wyznanie religijne.

Wszystkie pojęcia kategoryzujące ludzi są umowne, silnie zrelatywizowane oraz powiązane z przestrzenią społeczno-kulturową [m.in. Major, O’Brien 2005; Pospiszyl 2008]. Jednakże atrybuty odpowiedzialne za wskazanie jednostki jako „innej” mają moc silnie różnicującą i lokującą napiętnowaną jednostkę w kategorii osób/grup dyskryminowanych, niepożądanych społecznie, niebezpiecznych czy niepełnowartościowych. Nosiciel piętna i tzw. normals [Goffman 2007] są fizycznie współobecni w przestrzeni społecznej, w której dochodzi do konfrontacji przyczyn i skutków napiętnowania. Tego rodzaju mieszane kontakty 
zwykle wyzwalają w napiętnowanej jednostce nerwowość i niepewność. Prowadzić to może do chaotycznej interakcji, w której nosiciel piętna będzie reagować defensywnie, albo będzie oscylować między lękiem a arogancją. Osoby napiętnowane mają zbliżoną karierę moralną, która jest skutkiem ich zaangażowania $\mathrm{w}$ podobny przebieg osobistych adaptacji oraz często doświadczają tożsamych stanów i zmian w koncepcji siebie [Goffman 2007, s. 66]. Dokonując retrospektywnej analizy własnej kariery moralnej, jednostka może wyodrębnić te doświadczenia, które w jej ocenie przyczyniły się do jej obecnego położenia oraz krystalizacji przekonań i prezentacji zachowań wobec „normalsów” i osób naznaczonych podobnie jak ona posiadaniem tego samego atrybutu. Zdarzenia z przeszłości mogą być zatem powiązane z karierą moralną, stanowiąc bezpośrednią i obiektywną podstawę do zmiany.

Jestem recydywista, siedze $w$ więzieniu już trzeci raz i stowo honoru, że nie zamierzam już tu więcej wrócić. Jak wyjdę na wolność i założę rodzinę, to będę miat dla kogo się starać. Jako 15-latek trafitem za kradzież do zaktadu poprawczego, a potem to już samo się nakręciło... Nie ożenitem się, bo każda z dziewczyn, z która się wiązatem, szybko ze mna zrywała, gdy dowiedziała się, że kryminalista jestem. A ja chciałbym mieć kogoś, kto by mnie kochat, chronit przed kumplami i głupotami. Zwyczajnie, brak mi ludzkiego ciepta... szczególnie teraz... I chyba to jest powodem, dla którego chce się zmienić. [A.F. - 30 lat, kawaler, mieszkaniec wsi, wykształcenie zawodowe, trzykrotny recydywista, wyroki skazujące za kradzieże]

Przeszłość może służyć także jako środek usprawiedliwiający sytuację, w której jednostka się obecnie znajduje.

Rodzice sie postarzeli i nie mieli już sit, aby pracować na roli. Dom trzeba byto jakoś utrzymać, a to co zarabiatem, nie starczało na życie. Nie chciatem pozwolić, aby ktoś z mojej rodziny głodowat. Nie mam zawo$d u$, ani specjalnie zdolny i robotny nie jestem, więc poszedtem na skróty... [K.M. — 45 lat, wykształcenie podstawowe, mieszkaniec wsi, recydywista trzykrotny, wyroki skazujące za kradzież oraz za kradzież z włamaniem]

Wyniki polskich nielicznych badań nad stygmatyzacją społeczną ekswięźniów sygnalizują niegasnący problem negatywnego, stereotypowego postrzegania tej grupy przez poprawnie funkcjonującą część społeczeństwa [m.in. Dykcik 2003; Marczak 2005; Jaworska 2008; Bednarski 2011; Florczykiewicz 2013; Paszkiewicz 2017; Nowak 2017a]. Uprzedzenia, tendencje segregacyjne i piętnujące utrudniają lub wręcz uniemożliwiają byłym więźniom pozytywną readaptację i finalnie reintegrację społeczną. Towarzyszą one dwu typom postaw: negującej i kasującej dewiacyjną tożsamość lub pogłębiającej zakorzenienie w świecie przestępczym [Ambrozik 2007]. Postawy te krystalizują się w toku procesu obejmującego działalność przestępczą, doświadczanie oddziaływań resocjalizacyjnych oraz deprywacyjnych skutków izolacji więziennej. 
Atrybut karalności i uwięzienia sprawia, że osoby, które go posiadają, określane są mianem kryminalistów i powszechnie uznawane za mniej wartościowe, bez względu na inne ich cechy, które w obliczu stygmatu nie mają znaczenia dla otoczenia społecznego. To sprawia, że byli więźniowie są społecznie nieakceptowani i odrzucani [Heatherton i in., 2008]. W innej kategorii postrzegania społecznego lokują się byli więźniowie polityczni z państw totalitarnych, którzy mimo naznaczenia atrybutem karalności, są traktowani przez opozycyjną część społeczeństwa oraz większość społeczeństw demokratycznych jako ludzie odważni, bohaterowie na rzecz zmiany, obrońcy wolności i praw człowieka.

Badania wskazują także, że sposób przetwarzania informacji już na etapie kodowania modyfikowany jest zaktywizowaną wiedzą stereotypową [Bodenhausen 1988; Bodenhausen, Kramer, Süsser 1994]. Informacja o przynależności sprawcy danego czynu do stereotypowo postrzeganej grupy (np. kryminalistów), zwiększa prawdopodobieństwo wystąpienia u obserwatorów przekonania o jego winie. Psychologowie wyjaśniają ten proces między innymi na podstawie dwóch teoretycznych modeli. Jednym z nich jest model selektywnego (tendencyjnego) przetwarzania informacji, który wpływ stereotypów na przekonania o winie wyjaśnia tym, że stereotypy ukierunkowują myślenie na przekonanie o ich słuszności i prowadzą do pomijania tych informacji, które nie odpowiadają stereotypowemu przekonaniu. Koncepcja selektywnego przetwarzania informacji czyni mechanizm poznawczy odpowiedzialnym za przypisywanie winy pod wpływem stereotypów. Selektywne przetwarzanie informacji pojawia się bowiem w sytuacji niewystarczających zasobów poznawczych, pod presją czasu lub z uwagi na złożoność analizowanego problemu [Van Knippenberg, Dijksterhuius, Vermeulen 1999]. Wpływ stereotypu na sądy o winie przypisywanej jednostce za dane zdarzenie ogranicza systematyczne przetwarzanie informacji. Drugi model wskazuje natomiast na interpretacje otrzymanych informacji kompatybilne ze stereotypem pod względem afektywnym lub narracyjnym. Stąd też używanie stereotypów w procesie formułowania sądów o winie nasilają negatywne emocje i/lub opinie oraz odniesienia społeczne.

Nieaprobowane społecznie zachowania członków napiętnowanych grup są postrzegane jako ich stałe dyspozycje. Również lęk i poczucie zagrożenia rodzące się w obliczu przynależności sprawcy danego czynu do stereotypowo postrzeganej grupy, mogą prowadzić do innych, równie negatywnych emocji odczuwanych w stanie wysokiego pobudzenia, np. złości czy wrogości [Sinclair, Kunda 1999; Jackson i in. 2001]. Co więcej, lęk rodzący się w relacjach międzygrupowych generuje bardziej stereotypowe postrzeganie grupy obcej [Wilder 1993].

Należy podkreślić, że użycie stereotypu w procesie atrybucji winy jest determinowane jego treścią, przekonaniem o cechach i dyspozycjach danej osoby do określonego postępowania, emocjami powiązanymi z naznaczoną grupą, poczuciem zagrożenia, którego źródłem jest stereotypowa wiedza lub afektem odczuwanym przez obserwatora. 


\subsection{Rola pamięci autobiograficznej w procesie adaptacji społecznej i psychologicznej}

W procesie adaptacji społecznej i psychologicznej fundamentalną rolę odgrywa oparta na zasobach pamięciowych zdolność człowieka do przewidywania przyszłości. Szczególne znaczenie w tym procesie psycholodzy przypisują pamięci autobiograficznej, mającej duże znaczenie dla społecznego funkcjonowania człowieka. Wiele wskazuje na to, że pamięć autobiograficzna jest częścią mechanizmu bieżącej regulacji zachowania człowieka oraz częścią jego osobowości odpowiedzialną za poczucie i trwałość tożsamości oraz stanowiącą — oprócz samooceny — jej bazowy element. Jak dotąd, pamięć autobiograficzna nie została jeszcze zdefiniowana w sposób zadowalający. Odnosząc się jednak do współczesnego dorobku polskiej psychologii, w moich rozważaniach nad oceną porażki readaptacyjnej w narracji recydywistów penitencjarnych, przyjmuję jako wiodące ujęcie, w którym pamięć autobiograficzna rozumiana jest jako pamięć deklaratywna, odnosząca się do własnej przeszłości [por. Maruszewski 2005, s. 31].

Pamięć autobiograficzna nie jest na ogół wierną kopią zapisu zdarzeń, ale pomimo tego wydatnie przyczynia się do skutecznej adaptacji społecznej i psychicznej człowieka oraz do sprawnej i efektywnej realizacji stawianych przez niego celów. Ma ona bowiem charakter generatywny - są w niej kumulowane dane podstawowe, a zarazem wyjściowe (fakty), które dopiero po przetworzeniu (interpretacje) służą regulacji zachowania czy też określaniu ścieżek własnego postępowania. Pamięć ta umożliwia człowiekowi nawiązywanie i utrzymywanie kontaktów z innymi ludźmi, wykorzystywanie wcześniejszych doświadczeń, stawianie sobie celów oraz planowanie działań. Nieprawidłowości występujące w obszarze pamięci autobiograficznej generują zwykle trudności w funkcjonowaniu społecznym.

Podstawową funkcją pamięci autobiograficznej jest przechowywanie informacji na temat indywidualnej historii życia. Pamięć ta nie musi wiernie zapisywać i odzwierciedlać przeszłości, by z powodzeniem spełniać funkcje przystosowawcze i zapewniać człowiekowi dobrą adaptację społeczną i psychiczną [Robinson-Riegler, Robinson-Riegler 2004]. Treści rejestrowane w pamięci autobiograficznej są swoiste i gromadzone w niej na podstawie specyficznych operacji ich kodowania, przetwarzania i odtwarzania. W toku podejmowanych przez człowieka interakcji społecznych, w tego rodzaju pamięci są rejestrowane informacje dotyczące jego własnego zachowania w przeszłości, jak też zachowania innych uczestników interakcji. Wyniki badań Burta, Kempa, Gradego i Conwaya [2000] dowodzą, że informacje te są następnie strukturalizowane zgodnie z zasadą chronologii (uporządkowania w czasie) oraz zasadą uporządkowania pojęciowego.

Pamięć autobiograficzna, będąca pamięcią dostępną świadomości ludzkiej, pojawia się dopiero na etapie kształtowania poczucia tożsamości i odrębności „Ja” [Conway, Pleydell-Pearce 2000], a składają się na nią: 
a) baza pamięci autobiograficznej, w której znajdują się informacje o poznawczej i afektywnej reprezentacji własnej tożsamości i siebie jako podmiotu doświadczenia (wydobywane z przeszłości, odnoszące się do teraźniejszości i dostrzegane w przyszłości) — jest to wiedza autobiograficzna oraz wspomnienia epizodyczne;

b) zbiór przekonań, ocen wlasnego postępowania i różnorakich obrazów „Ja” (tzw. robocze koncepcje siebie), służący niwelowaniu rozbieżności pomiędzy pragnieniami a standardami moralnymi i wzorami postępowania.

Odnosząc się do autobiograficznych wspomnień, człowiek uruchamia wiedzę autobiograficzną będącą zapisem zdarzeń i informacji z przeszłości. Pamięć o nich występuje w formach, które różnią się wymiarem czasu, wokół którego budowane jest wspomnienie oraz stopniem szczegółowości i konkretności. Informacje dotyczące dłuższych odcinków czasu zapisywane są w pamięci ludzkiej w sposób bardziej ogólny i mniej konkretny niż epizody. W większym stopniu jest to także wiedza dzielona $\mathrm{z}$ innymi, obejmująca normy obyczajowe, prawne czy moralne [Conway, Pleydell-Pearce 2000].

Oprócz wiedzy autobiograficznej znaczący udział w konstruowaniu wspomnień mają: wiedza operacyjna wraz z jej ograniczeniami, cel wydobywania z pamięci danego wspomnienia, bieżący stan emocjonalny, a zwłaszcza osoba, której wspomnienie jest relacjonowane. Z kolei na epizody, czyli większe całości, składają się pojedyncze zachowania, zdarzenia i sytuacje [Tulving 2002]. W osobistych rozważaniach człowieka nad naturą ludzką, tworzonych poprzez doświadczanie świata wraz z innymi ludźmi [Łukaszewski 1997], epizody zdarzeń mogą zmieniać swój sens. Z perspektywy czasu pierwotna ocena własnych zachowań może bowiem ulec transformacji, szczególnie gdy efekt interakcji nosi znamiona traumy. Wraz z upływem czasu i ilością odtworzeń, informacje o dawnych wydarzeniach mogą ulegać także licznym modyfikacjom. Łączy się to z tendencją do podnoszenia własnej atrakcyjności i wzmacniania zaciekawienia słuchaczy przeżytymi przez narratora historiami. Dominującą częścią pamięci autobiograficznej są narracje, rozumiane jako historie ciągów zdarzeń. Nie jest to jednak stwierdzenie jednoznaczne, gdyż niektórzy badacze uznają, że w postaci narracji przejawia się właśnie ten rodzaj pamięci [Rubin 1995].

Cechy pamięci autobiograficznej są inne niż właściwości pozostałych rodzajów pamięci. Treści w niej zapisywane są bardzo silnie sprzężone z kontekstem, w ramach którego są one interpretowane i oceniane oraz obdarzone silnym ładunkiem emocjonalnym, gdyż odnoszą się do ważnych spraw osobistych. Przede wszystkim nie są one, tak jak w przypadku innych rodzajów pamięci, poddawane filtrowaniu, podczas którego informacje ważne oddzielane są od mało istotnych, ani też specyficznie obrabiane w celu łatwego zapamiętania czy uzyskania odpowiedniej siły wpływu na zachowanie [Berntsen, Rubin 2002]. Materiał pamięciowy dotyczący własnej biografii jest efektem zachowań lub działań danego człowieka i innych ludzi — stąd też jest bardzo konkretny i pozyskiwany wskutek doświadczania faktów. 
Informacje pochodzące z pamięci autobiograficznej wpływają na działania i plany człowieka, które odnosi on do realnej rzeczywistości. Pamięci autobiograficznej nie należy jednak utożsamiać z doświadczeniem życiowym, gdyż jest ona jego deklaratywnym składnikiem, współobecnym z innymi, niedeklaratywnymi elementami, w tym zdolnościami proceduralnymi [Niedźwieńska 2000]. Innym ważnym aspektem $\mathrm{w}$ analizie różnic między pamięcią autobiograficzną a doświadczeniem życiowym są zdarzenia traumatyczne, których przywoływanie czy też refleksyjne rozpatrywanie jest trudne dla ludzi ich doświadczających. Należy podkreślić, że informacje o udziale w zdarzeniach traumatycznych w roli aktora lub obserwatora są kodowane w pamięci ludzkiej w sposób fragmentaryczny, co powoduje, że pojawiające się w świadomości wycinki sytuacji nasyconej negatywnymi emocjami, mogą być uznane za własne doświadczenia lub mogą generować proces tłumienia, blokujący dostęp do informacji istotnych dla całej sytuacji [Maruszewski 2005].

Zdarzenia traumatyczne sąźródłem wspomnień intruzywnych, które pojawiają się u uczestnika tego typu zdarzenia wskutek automatycznego przypominania, niezależnego od jego intencji. Mają one charakter spontaniczny, niepowszechny i dysfunkcjonalny. W sytuacji ich doświadczania człowiek odczuwa zakłócenia poznawcze oraz znaczący dyskomfort emocjonalny, które to stany znacząco dezorganizują jego funkcjonowanie. Wspomnienia intruzywne są szczególnym przypadkiem mimowolnych wspomnień autobiograficznych, odnoszących się do osobistej przeszłości [Mace 2007]. Należy podkreślić, że zarówno wspomnienia mimowolne, jak i intruzywne odbiegają od prawidłowego funkcjonowania pamięci ludzkiej - mają one charakter patologiczny i dotyczą wyłącznie osób, które doświadczyły zdarzenia traumatycznego [Berntsen 2010].

Osoby niedostosowane społecznie i wykolejone często doświadczają w dzieciństwie i wczesnej młodości wielu traumatycznych wydarzeń rozgrywających się w ich dysfunkcjonalnym środowisku rodzinnym i/lub dotkniętym patologią (przestępczością, przemocą czy uzależnieniami) [Pospiszyl 2009; Margasiński 2010; Albański 2010; Nowak 2011; Sigda, Matusiak 2016; Ostafińska-Molik, Wysocka 2016; Nowak 2017]. Wspominając rodzinę pochodzenia, wydobywają oni z pamięci obrazy smutnej, często tragicznej w skutkach dziecięcej rzeczywistości oraz sceny dramatycznych zdarzeń i przemocowych zachowań rodziców.

Pamiętam, jak mój biologiczny ojciec znęcat się nad moja matka. Matka rozwiodta się z ojcem i zwiazala z ojczymem, jak miałem 6 lat. Nie utrzymywatem zbyt dobrego kontaktu z ojcem, ale wiem, że parę razy siedziat i później próbowat sobie ułożyć życie, ale mu nie wychodziło... [A.F. 42 lata, wykształcenie średnie, recydywista czterokrotny, wszystkie wyroki skazujące za kradzieże]

Moje dzieciństwo byto parszywie smutne. Rodzice rozwiedli się, jak miałem kilkanaście lat. Przebywatem często $w$ pogotowiu opiekuńczym 
$i$ w domu dziecka na czas rozwodu rodziców. Później to już był zakład poprawczy. [R.O. 43 lata, wykształcenie zawodowe, recydywista sześciokrotny: wyroki skazujące za fałszerstwa, wyłudzenia i kierowanie pojazdem pod wpływem alkoholu]

Rodzice kochali nas, ciężko pracowali, aby jakoś nam się żyło. Z czasem byto coraz gorzej, bo ojciec zacząt więcej pić, więc i brakowato pieniędzy, dlatego potem pomagatem im finansowo. Najgorsze to byty ojca powroty do domu po libacjach — zrywał nas w środku nocy, wrzeszczat, bit $i$ w las kazał uciekać, a mamę bit prawie do nieprzytomności, bo za nami stawała. [K.T. 38 lat, wykształcenie zawodowe, recydywista trzykrotny, wyroki skazujące za kradzieże i kradzież z włamaniem]

W pamięci autobiograficznej lokowane są informacje faktograficzne oraz informacje na temat ciągów zdarzeń. Są one w niej kodowane w postaci zapisu obrazowego, werbalnego i abstrakcyjnego [Maruszewski, Ścigała 1998]. Ten rodzaj pamięci jest szczególnie zasobny w obrazy zdarzeń, w których człowiek uczestniczy w ciągu swojego życia [Rubin 1995, s. 1-15), a wyrazistość obrazu danego zdarzenia determinowana jest temporalnie — im krótszy jest czas „leżakowania” informacji, tym więcej danych obrazowych ona zawiera [Conway, 1996, s. 67-93]. Na informacje werbalne składają się różnorodne, odporne na zmiany dane służące jednostce do identyfikacji (np. imię czy data urodzenia), zaś wszelkie informacje służące do rozumienia przez nią własnej biografii identyfikowane są jako dane abstrakcyjne. Informacje względnie świeże są bardziej dokładne i konkretne oraz przechowywane w postaci wiernie odtwarzającej zdarzenie, zwłaszcza gdy było ono nasycone emocjami, w przeciwieństwie do informacji długo przechowywanych, które są z kolei kodowane i przechowywane w postaci schematów, i które cechuje słaba wyrazistość emocjonalna.

W pamięci autobiograficznej oprócz faktów pojawiają się także ich interpretacje. W sytuacjach obronnych człowiek często myli je ze sobą i wówczas dochodzi do różnorakich zniekształceń będących źródłem zaburzeń narracyjnych. Stąd też interpretacje jawią się jako swoista furtka dająca możliwość dokonywania zmian w osobowości jednostki poprzez reorientację postrzegania przez nią jej osobistej przeszłości. W pamięci autobiograficznej przechowywane są również skrypty poznawcze, które stanowią reprezentacje zdarzeń. Skrypt ma charakter sceny i zawiera treści dotyczące określonych zdarzeń, ich uczestników, obiektów typowych w scenach, warunków uruchamiających scenariusz i rezultatów końcowych. Można stwierdzić, że jest to rodzaj schematu zdarzeń, który człowiek konstruuje na podstawie przekazów społecznych oraz własnych celów i doświadczenia [Maruszewski 2005]. Ważną rolę w regulacji zachowań ludzkich odgrywają także obecne w pamięci autobiograficznej skrypty afektywne będące formą zapisu zdarzeń nasyconych dużym ładunkiem emocjonalnym, zarówno pozytywnym, jak i negatywnym. 
Pamięć autobiograficzna jest pamięcią trwałą, ale człowiek może sam decydować o głębokości i zasięgu kodowania pozyskanych informacji (płytko, pobieżnie, wybiórczo lub głęboko, precyzyjnie, całościowo). W procesie kodowania istotne są również: rodzaj treści przeznaczonych do zapamiętania (ważne lub mniej istotne), właściwości przeżywanych sytuacji [Tulving 1985] oraz ich znaczenie dla poczucia własnej wartości i samooceny. Człowiek dokonuje bowiem selekcji $\mathrm{w}$ obrębie informacji dla niego ważnych — w inny sposób zapamiętuje własne sukcesy czy porażki niż zdarzenia, w których odczuwa wstyd, czy samozadowolenie graniczące z poczuciem dumy. Ważny jest również kontekst relacjonowania innym epizodów czy całej swojej historii życia [Bruner 1992]. Ta sama informacja ulega modyfikacji w zależności od tego, kto jej słucha (np. przypadkowo poznana osoba, przyszły pracodawca, terapeuta, dziennikarz czy partner życiowy).

Wskutek wystąpienia wyżej wspomnianych czynników mogą i najczęściej występują problemy z interpretacją danych pozyskanych drogą narracyjną i przekazywanych w procesie ujawniania siebie (self-disclosure). Człowiek opowiadający o epizodach czy też całej historii swojego życia przedstawia słuchaczom informacje w sposób przez siebie kontrolowany. To on decyduje o rozmiarach zbioru przekazywanych innym informacji oraz o ich rodzaju — czy wyjawi dane powierzchowne, ogólnodostępne, czy będące jego tajemnicą [Taylor, Altman 1987, s. 257-277].

Ludzie ujawniają zazwyczaj zdecydowanie więcej informacji osobom dla nich ważnym, z którymi są w bliskich relacjach. To, ile i co człowiek ujawnia innym, zależne jest także od efektów socjalizacji i wychowania, a także od warunków socjo-kulturowych, w których procesy te przebiegały. W odniesieniu do specyficznych narratorów, jakimi są recydywiści penitencjarni, założyłam, że mogą oni dzielić się informacjami z życia prywatnego z osobami obcymi, wiedząc, że przypuszczalnie nigdy więcej nie będą mieli z nimi kontaktu. Powyższa teza legła u podstaw przyjętej przeze mnie strategii badawczej, pomimo niebezpieczeństwa wynikającego z faktu, iż w przypadku płytkich, jednorazowych kontaktów ludzie ujawniają jedynie informacje o postawach, myślach czy uczuciach aprobowanych społecznie [Maruszewski 2005]. W interpretacji uzyskanych danych badawczych wzięłam również pod uwagę związek między rozmiarami ujawnionych informacji a jakością przystosowania społecznego. Okazuje się bowiem, że ludzie ujawniający siebie zarówno w stopniu wysokim, jak i niskim, są słabo przystosowani, zaś ci, którzy czynią to w sposób umiarkowany, wykazują najwyższy poziom przystosowania [ibidem]. Założyłam także, że ponieważ generatywne działanie pamięci autobiograficznej sprzyja otwartości poznawczej, to przywoływanie zdarzeń z przeszłości może wywołać u badanych recydywistów refleksję i wzbudzić w nich przekonanie, że przyszłość nie jest repliką przeszłości, że można zmienić swoje dotychczasowe życie wskutek zmiany scenariusza przyszłych zdarzeń. 
Aby tak się stało, oni sami muszą podjąć wysiłek nad przewartościowaniem swojego dotychczasowego życia wraz z opanowaniem umiejętności radzenia sobie z problemami i wyzwaniami w sposób odmienny od dotychczasowego - konstruktywny i ukierunkowany na rozwój osobisty, zwłaszcza kompetencyjny, dający realną szansę na pozytywną reintegrację społeczną i godne życie. 
Poznawcza odwaga musi towarzyszyć każdej interpretacji zawsze nieprzejrzystego, ludzkiego zachowania.

Wiktor Marzec [2011] 


\section{Część III \\ Porażka readaptacyjna w narracji recydywistów penitencjarnych (badania własne)}



Rozpatrując zagadnienie recydywy, zastanawiałam się nad tym, co sprawia, że po odbyciu dotkliwej kary izolacji więziennej i przeżyciu silnej deprywacji potrzeb, część skazanych decyduje się na ponowne popełnienie czynu przestępczego, narażając się na powtórne uwięzienie i doświadczanie sytuacji niezwykle niekorzystnej z punktu widzenia każdego człowieka. Oczywiście może zdarzyć się, że kara ich nie dosięgnie (np. nie zostaną zatrzymani przez organy ścigania) i nie zostaną ponownie skazani i uwięzieni, ale dlaczego podejmują takie ryzyko?

\subsection{Izolacja więzienna i jej skutki}

Próbę odpowiedzi na to pytanie rozpocznę od omówienia perturbacji wynikających z izolacji więziennej, a wiążących się z określonymi aspektami środowiska życia człowieka: stymulacyjnym, funkcjonalnym, przestrzenno-czasowym i społecznym [Ciosek 1987; Tomaszewski 1977].

1. Ubóstwo stymulacyjne środowiska więziennego jest efektem dostosowania jego elementów do specyfiki kary izolacji, zwłaszcza tych, które ograniczają stymulację sensoryczną [Mass 2007, s. 32], czyli możliwość rejestrowania informacji ze świata zewnętrznego przez narządy zmysłów, ich przetwarzania w ośrodkowym układzie nerwowym i wykorzystania do celowego działania. Nośnikami ubóstwa stymulacyjnego w zakładzie karnym są między innymi:

- architektura więzienna ograniczająca dopływ bodźców zewnętrznych wysokie, grube mury z zabezpieczeniami; kraty okienne i rozdzielające poszczególne segmenty i przejścia; w celach małe okna usytuowane wysoko, poza możliwością wyjrzenia przez nie na zewnątrz; wewnętrzny, odizolowany i otoczony wysokim murem dziedziniec spacerowy oraz wielość innych elementów uniemożliwiających kontakt (zwłaszcza wzrokowy) ze światem zewnętrznym;

- ubóstwo barw (dominujące: czerń, szarość, kolory ziemi), negatywnie wpływające na procesy emocjonalno-motywacyjne oraz stan układu nerwowego więźniów [Sikora 1971];

- nuda - przykry i destrukcyjny stan emocjonalny będący wynikiem rutynizacji i monotonii życia więziennego, nieustannej koncentracji na upływie czasu oraz surowej dyscypliny. 
2. Funkcjonalny aspekt środowiska więziennego powiązany jest ściśle z deprywacją potrzeb fizycznych i psychicznych osób osadzonych. Szereg dolegliwości przez nie doświadczanych to efekt niezgodności życia więziennego z indywidualnym systemem wartości, potrzeb i możliwości. Dolegliwości te generowane są między innymi przez:

- znaczne ograniczenie swobody działania i kontaktów z osobami bliskimi;

- naruszenie dotychczasowych więzi z rodziną oraz obawa przed negatywną oceną społeczną - sąsiadów, znajomych, pracodawców;

- brak możliwości zaspokojenia potrzeb mieszkaniowych (mała przestrzeń, hałas, brak światła etc.) oraz żywieniowych (brak możliwości decydowania o codziennym menu, monotonia żywienia zbiorowego);

- pozbawienie kontaktów heteroseksualnych;

- pozbawienie możliwości podejmowania decyzji i dokonywania wyborów;

- utrata poczucia bezpieczeństwa lub świadomość możliwości jego utraty (przeludnienie cel i związane z tym konflikty między współwięźniami skutkujące aktami agresji i przemocy).

Cechą środowiska więziennego jest skomasowanie więźniów na stosunkowo niewielkiej przestrzeni oraz upływ czasu i jego trudne samotne przeżywanie. W więzieniu czas staje się problemem, gdyż boleśnie odczuwany jest jego nadmiar przy braku swobody działania. W takiej sytuacji wszystko wokół wydaje się nierealne, znacząco inne od świata zewnętrznego i tego, co wcześniej było postrzegane, doświadczane i emocjonalnie odbierane. Stan ten potęgują cechy homogenicznej społeczności więziennej - skomplikowane mechanizmy jej funkcjonowania, podkultura więzienna, a także dychotomiczny układ zależności: osadzeni versus personel więzienny. W generowaniu tych negatywnych skutków uwięzienia niebagatelną rolę odgrywają procesy: stygmatyzacji, degradacji, depersonalizacji oraz prizonizacja.

Stygmatyzacja rozpoczyna się już w fazie czynności dochodzeniowych i aresztowania, gdy jednostka zostaje odizolowana od większości społecznej. Wyrok skazujący rozpoczyna pierwszy etap naznaczenia instytucjonalnego, po czym następuje kolejny - już w instytucji zamkniętej, posiadającej prawo i odpowiednie środki do dalszej etykietyzacji osób w niej osadzonych. Nieustanne piętnowanie skazanych trwa przez cały okres izolacji więziennej — utwierdzani są bowiem w przekonaniu, że utracili status prawowitego obywatela na rzecz statusu przestępcy, co prowadzi do aktywacji procesu identyfikacji, a następnie do solidarności więziennej, przekształcającej się z czasem w charakterystyczną formę zwaną podkulturą więzienną. Rozwojowi tego zjawiska sprzyja standaryzacja, czyli proces unifikacji związany z postępowaniem ze skazanymi ściśle według regulaminu więziennego (m.in. uniformizacja ubioru, jednakowe sposoby zaspokajania potrzeb podstawowych, ten sam rodzaj i ilość mienia osobistego). Osadzeni przeżywają także liczne sytuacje traumatyczne, gdyż stają się przedmiotem degradacji - są znieważani, upokarzani i poniżani nie tylko przez silniejszych współwięźniów, ale także przez funkcjonariuszy więziennych, choć takie przypadki stanowią bezwzględną mniejszość. W aspekcie prawnym 
skrajne przypadki znęcania się regulowane są w art. 247 k.k. Bezpieczeństwo osadzonych może być zagrożone wskutek działań współosadzonych, funkcjonariuszy i pracowników Służby Więziennej [Michalska, Michalski 2020]. Źródłem zagrożeń poczucia bezpieczeństwa osobistego mogą być także pośrednio członkowie rodzin osób osadzonych czy pozostający na wolności członkowie grup przestępczych [Hołda, Postulski 2005]. Do obniżenia poziomu poczucia dobrostanu osadzonych przyczyniać się mogą także czynniki zewnętrzne (np. zagrożenie epidemiologiczne, stany kryzysowe wywołane zdarzeniami o zasięgu globalnym, katastrofy klimatyczne) oraz zdarzenia wewnątrz jednostek penitencjarnych (np. bunt więźniów czy stany nadzwyczajne) [Kalisz 2017; Szymanowski 1998].

Implikacją wynikającą $\mathrm{z}$ rozpoczęcia standardowych więziennych procedur oraz zaistnienia sytuacji i zdarzeń godzących w poczucie bezpieczeństwa osadzonych jest powolny, ale sukcesywnie postępujący proces depersonalizacji. Wraz z rozpoczęciem procesu adaptacji do życia w środowisku więziennym następuje u osadzonych zmiana tożsamościowa w kierunku postrzegania siebie w przypisanej nowej roli - kryminalisty. Im dłuższy jest okres alienacji, tym coraz mocniej rola ta jest przez więźniów internalizowana, aż staje się ich swoistym kostiumem tożsamościowym [Konopczyński 2006]. Dlatego też na skutki tego procesu narażeni są zwłaszcza ci osadzeni, którzy odbywają kary długoterminowe.

Należy jednak podkreślić, że ścieżka skazania prowadząca do osadzenia w zakładzie karnym wiąże się z podwójną zmianą tożsamościową. Pierwsza, wynikająca $\mathrm{z}$ uruchomienia zjawiska stygmatyzacji społecznej, jest zmianą rewolucyjną, której zaczynem jest moment skazania, nadania etykiety kryminalisty oraz ulokowania osoby skazanej w jednostce penitencjarnej. Druga zmiana - ewolucyjna - dotyczy konieczności podejmowania przez osoby osadzone specyficznych dla środowiska więziennego interakcji/transakcji, wynikających z uwarunkowań systemu penitencjarnego. Powodują one sukcesywnie postępującą transformację myślenia osadzonych o sobie aż do momentu akceptacji, identyfikacji i przyjęcia piętna.

Wraz z upływem czasu więźniowie asymilują się stopniowo do warunków izolacyjnych (proces prizonizacji). Opanowują w coraz większym stopniu wiedzę na temat organizacji i funkcjonowania zakładu karnego, specyficznych dla środowiska więziennego zwyczajów, rytuałów, sposobów zachowania oraz języka więziennego [Ciosek 2003]. Pierwszym badaczem, który na początku XX wieku analizował proces stawania się więźnia częścią izolowanego świata, był Donald Clemmer [1950]. Prizonizację wiązał on z przyjmowaniem ustalonych sposobów funkcjonowania, dostosowaniem się do panujących obyczajów i zasad ogólnej kultury więzienia oraz wskazał na uniwersalne czynniki tego procesu: akceptację roli podwładnego, dostosowanie się do organizacji i funkcjonowania więzienia, a zwłaszcza wykształcenie się nawyków związanych z życiem codziennym i więziennym rytmem dnia oraz opanowanie specyficznego języka, którym posługują się osadzeni [ibidem, s. 316]. 
Tempo i stopień prizonizacji są jednak silnie zindywidualizowane i zależne od powiązanych ze sobą czynników: osobowości więźnia i jego podatności na wpływy podkulturowe, składu osobowego współwięźniów w celi, stopnia akceptacji reguł i norm więziennych oraz rodzaju i zakresu relacji społecznych nawiązanych przed osadzeniem i utrzymywanych w trakcie izolacji z osobami funkcjonującymi na wolności. Inne czynniki to między innymi: wiek, historia karalności, w tym wcześniejsze epizody izolacyjne oraz narodowość. Proces integracji z kulturą więzienną oraz proces readaptacji do warunków wolnościowych po zakończeniu odbywania kary, determinowany jest także wymiarem kary — im jest on krótszy, tym istnieje większa szansa na pozytywną readaptację społeczną. Jednak nie zawsze dobrze sprizonizowany więzień jest po opuszczeniu zakładu karnego zresocjalizowanym ekswięźniem i dobrym obywatelem [Machel 2003].

Osadzeni w zakładach karnych, zwłaszcza więźniowie długoterminowi, przyjmują różnorodne strategie adaptacyjne, umożliwiające im dostosowanie się do warunków izolacyjnych. Interesujące badania nad przebiegiem procesu prizonizacji więźniów bezterminowych (skazanych na dożywocie) zostały przeprowadzone przez Joannę Klimczak [2017]. Autorka badania wzięła pod uwagę postrzeganie przez badanych więźniów własnych szans na warunkowe, przedterminowe zwolnienie. Na podstawie tego kryterium wyodrębniła następujące kategorie więźniów, opisujące w sposób metaforyczny stopień prizonizacji [ibidem, s. 238-240]:

a) wtapiający się $\mathbf{w}$ więzienie - osadzony zakorzenia się $\mathrm{w}$ więziennej rzeczywistości; porzuca wizję swojego życia na wolności; ma dobre relacje z funkcjonariuszami i wypracowuje taktyki dające mu poczucie dobrostanu w warunkach izolacyjnych, co sprawia, że dobrze się czuje w roli więźnia;

b) pieczeniarz - sam wypełnia sobie czas (w miarę możliwości); skupia się na sobie i sprawach bieżących; nie wierzy w pozytywną zmianę swojego losu, ale nie wyklucza możliwości opuszczenia więzienia w przyszłości;

c) widzący światlo w tunelu — jest świadomy wymiaru kary i swoje funkcjonowanie w więzieniu postrzega jako tunel zwieńczony odległym światełkiem; w trakcie tej drogi do wolności wyznacza sobie cele i zadania ukierunkowane na zwiększenie swoich szans na warunkowe, przedterminowe zwolnienie;

d) przyjmujący iluzoryczną postawę „mnie tu nie ma” - czuje się on częścią świata, w którym żył na wolności; nie akceptuje siebie w roli więźnia; kwestionuje swoją winę w przestępstwie i kontestuje wymiar otrzymanej kary; przyjmuje różne strategie: nie radzi sobie, buntuje się, opracowuje plan działania zwiększający jego szansę na wyjście na wolność.

Powyższe kategorie zostały wyodrębnione przy uwzględnieniu trzech czynników składających się na proces prizonizacji: przeszłości osadzonego, jego osobowości i środowiska więziennego oraz nawiązywanych relacji z funkcjonariuszami i współwięźniami.

Gdybyśmy poprzestali jednak na przyjęciu tezy, że przez prizonizację osoba inkancerowana jest do końca życia naznaczona etykietą kryminalisty, podważylibyśmy tym samym sens istnienia systemu penitencjarnego. Zdejmowanie 
kryminalnego piętna rozpoczyna się od podjęcia przez personel więzienny różnorakich oddziaływań resocjalizacyjnych, a kończy wraz z przygotowaniem skazanych do wyjścia na wolność. Jest to proces, który wymaga wielorakich i wielokierunkowych działań - niezwykle trudny, z odroczonymi w czasie efektami. W realiach więziennych, w warunkach opresyjnych i w społeczności jednorodnej, wręcz niemożliwe staje się oddziaływanie zindywidualizowane, znacznie zwiększające szanse skazanych na pozytywne przystosowanie do warunków wolnościowych.

Jednym z podstawowych warunków, a jednocześnie wyznaczników skutecznej readaptacji, a finalnie reintegracji społecznej, jest praca z osadzonymi, ukierunkowana na transformację myślenia przestępczego $\mathbf{w}$ nieprzestępcze, zgodnie z wyróżnionymi przez Waltersa dymensjami:

- od uśmierzania (przenoszenie własnej winy na okoliczności zewnętrzne lub innych ludzi) do odpowiedzialności za własne zachowanie społeczne;

- od odcięcia (lekceważenie sankcji prawnych) do internalizacji własnej winy i konsekwencji otrzymanej kary;

- od roszczeniowości (prawo do zachowań innych niż aprobowane społecznie) do uznania zachowań aprobowanych społecznie za wyznaczniki własnego postępowania;

- od infantylizmu uczuciowego (gra pozorów - przedstawianie siebie jako ofiary i eksponowanie własnej słabości) do realnej wizji siebie jako sprawcy i poczucia skuteczności własnej w procesie zmiany tożsamościowej;

- od zorientowania na siłę (lokowanie siebie w grupie dominującej w celu odczuwania kontroli nad otoczeniem) do zorientowania na przystosowanie do życia według wyznaczonych reguł i obowiązujących norm społecznych;

- od hiperoptymizmu (nadmierna pewność siebie i odrealniona wizja konsekwencji własnych czynów aspołecznych) do realnej wizji siebie i konsekwencji popełnionych czynów;

- od bierności poznawczej (niechęć do wysiłku umysłowego i poszukiwanie podniet w otoczeniu) do aktywności poznawczej i rozwoju intelektualnego;

- od braku ciągłości działania (niekonsekwencja w myśleniu i działaniu) do respektowania uzgodnień i realizacji umów.

Brak wspomagania readaptacyjnego, wspomaganie niewystarczające lub nieadekwatne do indywidualnych potrzeb osób skazanych (zarówno na etapie odbywania kary izolacji, jak i po jej zakończeniu i powrocie do środowiska życia na wolności) skutkują niewydolnością systemową oraz generują u części ekswięźniów „odrodzenie” myślenia przestępczego, a następnie wcielenie się na nowo w rolę przestępcy i jej urzeczywistnienie.

Polski Kodeks karny przewiduje trzy formy recydywy (powrotności do przestępstwa):

1) recydywę ogólną, oznaczającą ponowne popełnienie jakiegokolwiek przestępstwa przez osobę już karaną i skazaną prawomocnym wyrokiem (art. 64 k.k.);

2) recydywę specjalną — zwykłą (art. 64 § 1 k.k.), dotyczącą osób, które odbyły co najmniej pół roku wcześniej orzeczonej kary pozbawienia wolności i popełniły podobne przestępstwo umyślne w ciągu 5 lat od zakończenia tej kary; 
3) recydywę specjalną wielokrotną — multirecydywę (w art. $64 \S 2$ k.k.) obejmuje ona osoby, które poprzednią karę pozbawienia wolności odbywały w warunkach recydywy, co oznacza, że co najmniej dwa razy odbywały taką karę; ta forma powrotności do przestępstwa dotyczy najcięższych przestępstw przeciwko życiu i mieniu (przestępstwo zgwałcenia, rozboju, kradzieży $\mathrm{z}$ włamaniem lub inne przestępstwo przeciwko mieniu popełnione z użyciem przemocy lub groźbą jej użycia).

Kodeks karny wykonawczy w art. 69 wskazuje rodzaje zakładów karnych, w tym przeznaczonych dla recydywistów penitencjarnych. Kolejny zapis (art. 70 $\S 1$ k.k.w.) dotyczy organizacji zakładów karnych dla recydywistów penitencjarnych, które mogą być typu zamkniętego, półotwartego i otwartego lub też mogą stanowić oddziały samodzielnych zakładów karnych innego rodzaju oraz aresztów śledczych (art. $72 \S 3$ k.k.w.). Regulacje dotyczące odbywania kary przez recydywistów opisuje natomiast art. 86 k.k.w. [Lelental 2017].

Ze statystyk Ministerstwa Sprawiedliwości opublikowanych w 2018 roku wynika, że w latach 2014-2018 ponowne przestępstwo w ciągu pierwszego roku popełniło 17,3\% skazanych (tj. 8 tys. 451 osób), którzy zakończyli odbywanie kary pozbawienia wolności w 2012 roku oraz 38,9\% (tj. 19 tys. 32 osoby) w ciągu 5 lat od wyjścia na wolność. W porównaniu z innymi państwami Unii Europejskiej ogólny wskaźnik recydywy Polsce nie jest jednak dramatycznie wysoki. Skazani opuszczający polskie więzienia rzadziej niż w innych krajach europejskich powracają do przestępstwa. Statystycznie rzecz ujmując,

polski osadzony, skazany najczęściej za przestępstwa przeciwko mieniu o średniej społecznej szkodliwości, obarczony jest istotnie niższym ryzykiem recydywy niż jego europejski odpowiednik, częściej odbywajacy kare za przestępstwa $z$ uzyciem przemocy, udziat $w$ zorganizowanych grupach przestępczych lub cięższe przestępstwa narkotykowe ${ }^{1}$.

Dlaczego jednak wskaźnik recydywy w Polsce jest nadal wysoki pomimo prowadzonych w jednostkach penitencjarnych oddziaływań resocjalizacyjnych, terapeutycznych oraz półrocznego przygotowania osadzonych do wyjścia na wolność? Odpowiedź na to pytanie jest trudna, niezwykle złożona i wymagająca głębokiego namysłu oraz holistycznego, a także interdyscyplinarnego ujęcia problemu.

W prezentowanym projekcie badawczym przyjęto najszersze ujęcie recydywy, określane mianem recydywy penitencjarnej. Należy podkreślić, że recydywa penitencjarna jest traktowana jako zjawisko powszechne, gdyż dotyczy znacznej grupy skazanych [Marek 2014, s. 313]. Oznacza to, że do grupy recydywistów penitencjarnych kwalifikowani są wszyscy sprawcy przestępstw, a nie tylko ci, którzy powrócili do przestępstwa w warunkach określonych w art. 64 k.k.

1 http://orka2.sejm.gov.pl/INT8.nsf/klucz/ATTB68JU5/\%24FILE/i26703-o1.pdf, s. 6 [dostęp: 15.11.2020]. 
Pomimo że zdaję sobie sprawę z faktu, że podmiot i przedmiot badania jest specyficzny, a ocena $i$ interpretacja danych badawczych jest obwarowana wieloma ograniczeniami i trudnościami, to podejmując się tego niełatwego zadania, postawiłam tezę wyjściową, a zarazem fundamentalną. Jestem bowiem przekonana, że na temat możliwości, ograniczeń i niepowodzeń w ponownym przystosowaniu się do warunków wolnościowych powinny wypowiadać się przede wszystkim osoby bezpośrednio zainteresowane i doświadczające skutków zarówno własnych usiłowań przystosowawczych, jak i działań społecznych w zakresie udzielanej im pomocy penitencjarnej i postpenitencjarnej.

\subsection{Ograniczenia i upośledzenia świata wewnętrznego osób skazanych}

W międzynarodowym dyskursie pojawiają się trzy główne stanowiska wobec izolacyjnego sposobu kontrolowania przestępczości. Pierwsze dotyczy przekonania, że pobyt w więzieniu tłumi zachowanie przestępcze poprzez opresyjne i surowe warunki więzienne czy negatywne piętno społeczne oraz że izolacja jest podstawowym środkiem prewencji w zakresie powrotności do przestępstwa. Drugie stanowisko odnosi się do tezy, że więzienia generują przestępczość, gdyż sytuacja uwięzienia wpływa destrukcyjnie na psychikę osób osadzonych, co zwiększa prawdopodobieństwo zaistnienia recydywy po zakończeniu ich pobytu w więzieniu. I wreszcie trzeci pogląd, który wskazuje na minimalny efekt resocjalizacyjny pobytu skazanych w więzieniu. Chodzi o to, że przestępcy posiadają szerokie spektrum postaw aspołecznych i zachowań, które w trakcie odbywania kary izolacji — poza nielicznymi wyjątkami — tylko w niewielkim stopniu zostają zmienione lub wręcz pozostają niezmienione. Zwolennicy tego poglądu podkreślają jednak, że dłuższy czas przebywania w więzieniu przestępców ukaranych za niezbyt ciężkie przewinienia jest czynnikiem wysokiego ryzyka ich powrotu do przestępstwa. Narażeni są oni bowiem na kontrsocjalizacyjny i kontrkulturowy wpływ przestępców skazanych za czyny ciężkiej wagi oraz oddziaływania podkultury więziennej.

\subsubsection{Wzory poznawcze a przestępczy styl myślenia}

Myślenie przestępcze jest silnie powiązane z zachowaniem przestępczym. Najsilniejszym prognostykiem popełnienia czynu przestępczego są u osób dorosłych postawy aspołeczne [Gendreau, Goggin, Law 1997]. Potwierdzają to liczne metaanalizy ukierunkowane na rozpoznanie przyczyn zachowań przestępczych u nieletnich oraz przestępczości powrotnej. Mniejsze znaczenie mają natomiast czynniki osobowościowe, temperamentalne i środowiskowe-rodzinne [za: Rode 2013]. 
Style myślenia przestępczego ukazują zdeformowany obraz siebie i otoczenia społecznego. Są efektem minionych interakcji, które jednostka przyjmuje w sytuacjach następczych. U badanych recydywistów rozpoznano wzory poznawcze odpowiadające wszystkim dymensjom wyróżnionym przez Waltersa. Charakteryzują one przestępczy styl myślenia, stosowany w celu usprawiedliwiania własnej lekkomyślności, impulsywności, natarczywości i niesolidności oraz łamania zasad życia społecznego. Zostały one omówione poniżej w układzie odzwierciedlającym częstość ich występowania.

1. Umniejszanie wlasnej odpowiedzialności za przejawiane zachowanie aspołeczne (odpowiednik „uśmierzania” w zestawieniu Waltersa). Osoby o takim wzorcu myślenia przestępczego przenoszą winę własną na różnorakie okoliczności zewnętrzne oraz lokują własne zachowania w kategorii powszechnej niesprawiedliwości i nieuczciwości.

Brak środków do życia zmusza człowieka do stawania na granicy — skoro nie może zdobyć legalnie pracy, to robi, co może, szczególnie, jeśli ma rodzinę, by zapewnić jej godny byt, nawet posuwa się do kradzieży. No bo co ma zrobić? Tak sobie myślę, że ludzie dziela się na szczęśliwców i ci żyja petna gęba oraz na takich jak my - pechowców, którzy zmuszeni sa przez otoczenie do radzenia sobie w nielegalny sposób. Tak właśnie urządzony jest świat. [P.C. - 37 lat, wykształcenie zawodowe, mieszkaniec średniego miasta, dwukrotny recydywista, wyroki skazujące za kradzieże]

2. Gra pozorów (odpowiednik ,infantylizmu uczuciowego”), która polega na eksponowaniu własnych słabości i ułomności oraz wskazywania ich jako odpowiedzialnych za popełnione czyny.

Miatem kiedyś dziewczynę i wszyscy się za nia ogladali. No i byt taki facet, co chodzit na sitkę $i$ strasznie mnie denerwowat, bo dostawiat się do niej. Każdy by się denerwowat. Bytem wtedy zamieszany w dilerkę narkotyków, ale sam nie bratem. Ja jestem strasznie narwany, a ta moja laska miata z nim jakieś uktady i okazało się, że ze złym gościem się zadała. No i stało się, ktoś go zabil, a mnie wrobili w to zabójstwo. Ja nie mógtbym tkną́ nawet muchy. To przez sędziego, to on mnie wrobit $i$ posadzit na 15 lat za niewinność. Taka to już jest ta sprawiedliwość, że ofiare skazuja, bo przecież to ten facet chciat mi odbić laskę. [M.U. - 34 lata, wykształcenie zawodowe, mieszkaniec małego miasta, recydywista jednokrotny, wyroki skazujące za kradzieże i bójki oraz za zabójstwo]

3. Apatia poznawcza (odpowiednik „bierności poznawczej”). Myślenie przestępcze oparte na tym wzorze poznawczym charakteryzuje osoby odczuwające niechęć do wysiłku umysłowego i fizycznego, rozleniwione i posiadające ubogi świat wewnętrzny. 
Nie cierpię się uczyć... słaba pamięc mam, a $i$ wole sobie na pryczy poleżeć, tak... podumać sobie lubię. W ogóle, to ruszać mi się, też nie chce. Jak patrze na wspótspaczy, co to w celi ćwicza, to niedobrze mi się robi... Jak jeszcze nie siedziatem, to z kumplami robiliśmy różne rzeczy, bo ja wplywowy jestem. Robiłem, co mi kazali, ale raz to wymyślitem sobie, że skubniemy moja ciotkę, co to z saksów wróciła i kasę w domu trzymała. $W$ Ameryce dziesięć lat pracowała... Ale heca z tego wyszła, bo ciotka dwa dni wcześniej forsę do banku oddała, a my nie wiedzac o tym, poturbowaliśmy ja trochę $i$ mieszkanie tak przetrzepaliśmy, że przez dwa miesiace remont robiła. Kumpli i mnie nie rozpoznała, bo takie maski sobie wycięliśmy z tektury, jak to nieraz widać na filmach (śmiech). [J.G. — 42 lata, wykształcenie podstawowe, mieszkaniec wsi, recydywista dwukrotny, wyroki skazujące za kradzież z włamaniem i rozbój]

4. Brak konsekwencji w działaniu (odpowiednik „braku ciągłości działania”). Osoby działające na podstawie tego wzorca poznawczego są przerzutne, niestałe i niekonsekwentne $\mathrm{w}$ działaniu, szybko reagują na bodźce zewnętrzne i równie szybko się „wypalają”. Nie znoszą wiązania się z innymi przez zawieranie uzgodnień lub umów (słownych i pisemnych).

W przerwach wolnościowych byłem kelnerem, ale niedtugo - kilka miesięcy. Pracowatem też w pizzerii, ale też dtugo tam miejsca nie zagrzatem. Ogólnie to kasa z moich interesów była. Pracować, nie trzeba było. Potrafitem szybko sobie zorganizować pieniadze. A na legalu nie bytbym $w$ stanie, tyle zarobic. Ja nie jestem typem spokojnym prosze Pani. U mnie to szybkie decyzje sq — umawiam się na robotę, ale gdy mi ktoś podpadnie, to niech dalej sam sobie radzi. Wogóle nie znoszę, wiązania się umowami, bo to tak, jakbym przysiegat kobiecie w kościele... Ja lubię ruch $w$ interesie, zmiany, wiatr w żagle, jak to się mówi... [D.Z. — 36 lat, wykształcenie średnie, mieszkaniec małego miasta, recydywista dwukrotny, wyroki skazujące za kradzieże i posiadanie narkotyków]

\section{Lekceważenie kary kryminalnej otrzymanej za wlasne aspołeczne} zachowanie (odpowiednik „odcięcia”). Ten wzorzec myślenia jest charakterystyczny dla osób, które stawiają się „ponad” groźbą sankcji prawnych za własną aspołeczność.

Napadatem na jubilerów. Znatem też kiedyś gościa, który kradt obrazy, strasznie dużo pieniędzy na tym zarabiat. I o to chodzi, ja nie widze innej szansy na szybki zarobek. Co jakiś czas posiedzę sobie, a potem mam $z$ czego żyć. Urobek daję do paserów i zanim mnie namierza, sprytnie gdzieś kase sobie chowam, ale gdzie, to nie powiem nawet na torturach (śmiech)... [M.R. - 34 lata, wykształcenie podstawowe, mieszkaniec wsi, trzykrotny recydywista, wyroki skazujące za napady i bójki] 
6. Przecenianie własnych możliwości (odpowiednik „hiperoptymizmu”). Osoby o tym wzorze poznawczym charakteryzuje nadmierna pewność siebie, niemal omnipotencja, wskutek czego pojawia się u nich odrealniona wizja konsekwencji własnych czynów przestępczych.

Pierwszy raz to było na początku lat 80., na Stużewcu miesiac siedziałem. Pani z kolegium zdenerwowała się na mnie, bo ja na okragło jeździlem autem na rauszu. Płacilem co i rusz grzywnę, $i$ wtedy dawatem znowu w gardlo, a w końcu ona mi powiedziała: nie Januszek, teraz już pójdziesz posiedzieć - masz miesiac bezwzględnego. Dali mnie tam, gdzie sami starsi byli. To była taka duża cela rozsadniejszych chłopaków i oni się mna zajęli. Wyttumaczyli, co mam robić, bo nie wiedziałem. Potem siedziatem jak każdy, za kradzieże aut, włamania do mieszkań, bo właśnie ja sobie tak kodowatem od starszych — jeździli samochodami, mieli dużo kasy, fajne dziewuchy i tak dalej, no i zaczałem z kumplami próbować takich rzeczy $i$ też czasem robiłem to na wtasna rękę, bo wiedziatem, że dam radę sam... Prawie zawsze się udawato i następnym razem też się uda - mam już bogate doświadczenie i nie dam się więcej złapać. [J.K. — 57 lat, wykształcenie zawodowe, mieszkaniec dużego miasta, recydywista pięciokrotny, wyroki skazujące za jazdę po alkoholu, kradzieże i włamania]

\section{Przekonanie o posiadaniu prawa do zachowań innych niż normatywne} (odpowiednik ,roszczeniowości”). Jest to myślenie typowe dla osób traktujących swoje postępowanie jako ponadnormatywne z uwagi na przekonanie o posiadaniu przez nich prawa do przekraczania uzgodnień społecznych.

Mam dziecko z konkubina. Teraz za alimenty siedze, ale to jest niesprawiedliwe. Ta moja konkubina pochodzi w Ukrainy. Na Ukrainie najpierw prace bym dostat, a nie od razu do więzienia. Tam masz tak, że to państwo daje ci pracę i zabiera ci kasę na dzieciaka. A jak Ty się migasz od roboty, to wtedy dopiero do pudta trafiasz. A tutaj jest tak, że od razu mnie pod sad dali - ja przecież nie mam pracy, to z czego mam płacić? I wsadzili mnie na 1,5 roku teraz... [A.Ł. — 42 lata, wykształcenie podstawowe, mieszkaniec wsi, czterokrotny recydywista, wyroki skazujące za kradzież, kradzież z włamaniem, napady i niepłacenie alimentów]

8. Poczucie mocy sprawczej (odpowiednik, ,zorientowania na siłę). Na podstawie tego wzorca poznawczego działają skazani dzielący ludzi na słabych i silnych, lokujący siebie w grupie dominującej nad grupą „,słabych” i rozporządzającej nią wedle własnego uznania w celu odczuwania osiągania kontroli nad otoczeniem.

Byty andrzejki, ostatki $i$ imieniny mojego brata... No $i$ się umówiliśmy, że pojedziemy na dyskoteke czterema samochodami $i$ w ogóle... bo to imieniny... Jak poszliśmy z takim Norbertem, to już nie było dla nas miejsca, więc 
powiedzieliśmy, no to dobra, my i tak tam dojedziemy. Miatem takiego kolegę, co miat złom samochodów. To on mi kiedyś pokazywat, jak w Polonezie trzeba zdjać taki panel i odpalić... No i nie poszliśmy do domu, bo powiedziatem do tego Norberta: ,,dawaj klucz, maskę i śrubokręt”... Pierwszego auta nie dato się odpalić, drugiego też nie... ale trzecie... udało się odpalić! Ależ dumny z siebie bytem, a Norbert to oczy zrobit jak piłki ping-pongowe! Pojechaliśmy na dyskotekę, wróciliśmy, zostawiliśmy tego Poloneza w kapuście, gdzieś tam, bo nam się gaz skończył... gdzieś na polu. [M.K. — 24 lata, wykształcenie średnie, mieszkaniec średniego miasta, recydywista jednokrotny, wyroki skazujące za posiadanie i rozprowadzanie narkotyków oraz kradzież samochodu]

Analizy badawcze wykazały, że dominującym wzorem poznawczym u recydywistów penitencjarnych jest ,umniejszanie własnej odpowiedzialności za przejawiane zachowanie aspołeczne". Usprawiedliwiają oni swoje postępowanie, czyniąc je niezbędnym w obliczu sytuacji trudnej. Innym, bardzo często występującym wzorem, jest „gra pozorów”. Najczęściej można ją zaobserwować u recydywistów jednokrotnych z miast średniej wielkości oraz z przygotowaniem zawodowym. Osoby o takim wzorcu myślenia przestępczego przedstawiają siebie w roli ofiar zachowań aspołecznych innych osób. Podkreślają własną uczciwość i niewinność, pomimo oczywistych dowodów winy. Stosują techniki manipulacyjne w celu uzyskania korzystnej autoprezentacji i pomniejszenia własnego, świadomego udziału w przestępstwie. Ten typ wzorca charakterystyczny jest także dla recydywistów z miast dużej wielkości, z wykształceniem zawodowym lub średnim.

Recydywistów poszukujących bodźców zewnętrznych i podatnych na sugestie, działających zazwyczaj pod wpływem własnych, irracjonalnych pomysłów cechuje ,apatia poznawcza”. Ten wzór poznawczy najczęściej dotyczy recydywistów mieszkających we wsiach i posiadających wykształcenie podstawowe.

„Brak konsekwencji w działaniu” to wzór odpowiadający recydywistom podejmującym prace dorywcze lub bez kontraktu w tzw. szarej strefie. Stosują oni także strategie unikowe w sytuacjach trudnych. Obie powyższe dymensje typowe są dla recydywistów pochodzących z niewielkich miejscowości i posiadających najniższy poziom wykształcenia.

Recydywiści cechujący się wzorem „lekceważenie kary kryminalnej otrzymanej za własne aspołeczne zachowanie", traktują swoje czyny jako ważne i podnoszące ich wartość własną oraz ocenę w środowisku przestępczym. Kara kryminalna $\mathrm{w}$ postaci izolacji więziennej jest $\mathrm{w}$ ich mniemaniu jedynie swoistym odpoczynkiem, dość niewygodną przerwą w przyjętym przez nich przestępczym stylu życia.

„Przecenianie własnych możliwości” jest charakterystycznym wzorem poznawczym dla recydywistów przekonanych o swoim szczęściu i niewykluczających kolejnych epizodów aspołecznych po zakończeniu pobytu w więzieniu. Ten styl myślenia przestępczego jest typowy dla recydywistów wielokrotnych.

Najrzadszymi wzorami poznawczymi występującymi u recydywistów penitencjarnych są: ,przekonanie o posiadaniu prawa do zachowań innych niż 
normatywne” oraz „poczucie mocy sprawczej”. W mniemaniu osób z pierwszą dymensją przejawiane przez nich zachowania przestępcze są efektem niedoskonałego i niesprawiedliwego funkcjonowania systemu sprawiedliwości. Przekonanie to pozwala im na przerzucenie winy za własne czyny przestępcze i nienormatywną sytuację, w której się znajdują, na społeczeństwo i system prawny. Uważają oni, że ich podstawowe potrzeby powinno zabezpieczyć państwo, którego są obywatelami. Gdy tak się nie dzieje, użalają się nad sobą i usprawiedliwiają tym swoje czyny niezgodne z obowiązującym prawem. Z kolei wzór „poczucie mocy sprawczej" charakteryzuje osoby z kręgu podkultury więziennej i byłych liderów grup przestępczych. Co ciekawe, ,poczucie mocy sprawczej” jest typowe dla recydywistów z wyższym wykształceniem.

W etiologii rozwoju kariery przestępczej istotną rolę odgrywają czynniki o charakterze podmiotowym. Zachowania naruszające normy społeczne są bowiem efektem działania standardów wewnętrznych, które ukierunkowują cele, uruchamiają posiadane umiejętności i dostosowują do nich okoliczności zewnętrzne. W aspekcie kryminologicznym potwierdzają to wyniki badań Iwony Niewiadomskiej i Joanny Chwaszcz [2010], dotyczące analizy decyzji podejmowanych przez sprawców przestępstw przeciwko mieniu oraz zabójców, które wskazują na sprawstwo osobowościowej orientacji wartościującej w odniesieniu do tego rodzaju zachowań antyspołecznych.

\subsection{2. Świat wartości w perspektywie kryminologicznej}

W powszechnym rozumieniu wartości oznaczają to, co jest godne posiadania lub też to, dzięki czemu coś jest dla danej jednostki lub grupy cenne [Stępień 2001]. Psychologowie traktują wartości jako istotne zmienne motywacyjne ukierunkowujące wybór celów oraz tendencji rozwojowych [Oleś, Oleś 1981] lub jako poznawcze reprezentacje ponadsytuacyjnych, godnych pożądania celów [Schwartz, Bilsky 1987; Schwartz 1992]. Socjolodzy natomiast traktują wartości jako przekonania określające godne pożądania sądy, zachowania i cechy poszczególnych grup społecznych lub społeczeństwa jako całości.

Wpływem wartości na ludzką egzystencję zajmowali się między innymi Gordon Allport i Milton Rokeach. Allport, uważany za pioniera psychologii wartości, wykorzystał elementy niepsychologicznej teorii Eduarda Sprangera, uznając ją za wartościową teoretyczną podstawę katalogu wartości i zaproponował sposób ich pomiaru. Skonstruowane przez G. Allporta i P. Vernona narzędzie (Study of Values, SoV) przeznaczone było do pomiaru sześciu typów osobowości wyróżnionych przez Sprangera, którym odpowiadało z kolei sześć głównych wartości [Allport, Vernon 1931]:

- typ teoretyczny (uznawanie prawdy, intelektualizmu, krytycyzmu oraz indywidualizmu);

- typ ekonomiczny (koncentracja na wartościach użytkowych, oszczędność, praktyczność, utylitaryzm); 
- typ estetyczny (dążenie do nadania zachowaniom pięknej, harmonijnej formy);

- typ społeczny (uznawanie za wartości naczelne miłości, pomocowości i szacunku do drugiego człowieka);

- typ polityczny (dążenie do władzy, siły, kierowania innymi ludźmi; typ religijny — ukierunkowanie na rozwój duchowy).

M. Rokeach [1973] zauważył jednak, że sześć wyróżnionych przez Allporta typów osobowości nie różnicuje ludzi w sposób wystarczający. Stąd też, zainspirowany koncepcją wartości jako standardów zachowania Williamsa oraz koncepcją wartości jako godnych pożądania środków lub celów Clyde’a Kluckhohna, wypracował własną teorię [Rokeach, Ball-Rokeach 1989, s. 775-784]. Rokeach rozumiał wartości jako nakazujące i zakazujące przekonania orzekające o ich przedmiocie [1973, s. 6-7]. Pojedynczą wartość postrzegał natomiast jako trwałe przekonanie odnośnie do określonego sposobu postępowania, wskazujące, że jest on osobistą lub społeczną preferencją $\mathrm{w}$ zestawieniu $\mathrm{z}$ alternatywnym sposobem postępowania lub ostatecznym stanem egzystencji. Na przykład „pokój na świecie” jest pożądany, a „wojna” nie, czy też „zbawienie” może być przedkładane nad „życie pełne wrażeń". Według teorii Rokeacha wartości tworzą hierarchiczny system, będący trwałą organizacją przekonań (uporządkowanych według względnej ważności) o priorytetach odnoszących się do sposobów postępowania lub stanów egzystencji. O stopniu podatności na zmiany decyduje położenie przekonań w systemie — im przekonanie ulokowane jest bardziej centralnie, tym trudniej jest je zmienić [1979].

Jedynym motywem aktywującym modyfikację systemową jest dążenie do podniesienia poczucia własnej wartości. Dochodzi do tego wówczas, gdy wyobrażenia danej jednostki o sobie są dla niej niezadowalające, co oznacza, że dostrzegła ona rozbieżność między własnymi przekonaniami, z których jedno dotyczy własnego ,ja”, zaś drugie jest wartością. W takiej sytuacji zmiana przekonań ma charakter konfrontacji danej osoby ze sobą. Z uwagi na to, że niezależnie od miejsca i czasu ludzie na całym świecie cenią podobne wartości, Rokeach wyodrębnił dwie podstawowe grupy wartości. Jedną z nich tworzą wartości ostateczne obejmujące główne, ponadsytuacyjne cele ludzkiej egzystencji. Drugą grupę natomiast wartości instrumentalne, opisujące ogólne sposoby postępowania i mające swój udział w realizacji wartości ostatecznych.

Na podstawie hierarchii wartości dokonywane są wybory, stawiane długoterminowe cele, przyjmowane określone sposoby zachowań w różnych sytuacjach społecznych. Jest to subiektywnie postrzegany, uporządkowany układ tzw. celów upragnionych, pełniący ważną, regulacyjną funkcję w modyfikacji sposobu ludzkiego myślenia i działania, którą mogą spełniać jedynie wartości uwewnętrznione [Niewiadomska, Chwaszcz 2010].

Osobowościowa orientacja aksjologiczna wyznacza preferencje wartości i norm w różnorakich sytuacjach społecznych. Dążąc do pozyskania określonej wartości, człowiek dostosowuje swoje myślenie i działanie do zastanych okoliczności, oszacowuje możliwości na poziomie mikroekonomicznym, a uzyskany bilans zysków i strat konfrontuje z własnymi standardami 
moralnymi (wewnętrznymi). Jest to możliwe z uwagi na posiadanie przez ludzi dyspozycji umożliwiających im dokonywanie wyborów oraz szacowanie kosztów i prawdopodobieństwa wystąpienia określonych skutków, a są to: intencjonalność, czyli ukierunkowanie na cel, dalekowzroczność przewidywań, samoregulacja oraz refleksyjność.

Neuronaukowcy [Moll, Zahn, de Oliveira-Souza i in., 2005; Moll, de Oliveira-Souza, Zahn 2008] wyróżnili cztery kategorie ludzkich działań aktywowanych różnorodną (negatywną lub pozytywną) motywacją:

- działania ukierunkowane na własne interesy, które nie mają wpływu na innych;

- działania ukierunkowane na własne interesy, ale mające negatywny wpływ na innych;

- działania korzystne dla innych — „altruizm odwzajemniony”;

- działania korzystne dla innych, ale bez korzyści dla podmiotu działania: pomaganie innym - ,autentyczny altruizm";

- kosztowne działania karzące łamanie norm — „altruistyczne karanie”.

Trzy pierwsze kategorie lokowane są w obszarze działania wszystkich istot żywych, czwarta i piąta przyporządkowane są wyłącznie człowiekowi, gdyż działania tego typu muszą być intencjonalne.

Za zarządzanie rozróżnianiem dobra i zła odpowiedzialna jest skomplikowana sieć mózgowych struktur korowych i podkorowych. Ich udział w myśleniu moralnym jest zmienny, gdyż aktywowane są one w zależności od znaku przeżywanych emocji. Na przykład podwyższona aktywność bocznych płatów czołowych występuje w sytuacjach, gdy człowiek reaguje oburzeniem na osoby łamiące normy moralne, natomiast za pozytywne emocje (ze współobecnym odczuwaniem zaufania i wzajemności) odpowiedzialne są okolice przyśrodkowe mózgu. Ponieważ różnice występują także między osobowymi i bezosobowymi decyzjami moralnymi, otrzymujemy skomplikowany i nieco zamazany obraz omawianego mechanizmu, zwłaszcza że wrażliwość moralna, motywacje i sądy moralne oraz rozumowanie moralne zależne są od odrębnych, ale nakładających się procesów [Harris 2012].

Badania I. Niewiadomskiej i J. Chwaszcz [2010], dotyczące analizy decyzji sprawców przestępstw przeciwko mieniu i zabójców, ukazały w zestawieniu wartości ostatecznych istotnie mniejsze nasilenie preferencji wartości związanych $\mathrm{z}$ poszukiwaniem sensu życia $\mathrm{w}$ transcendencji oraz $\mathrm{z}$ jakością relacji interpersonalnych. W zbiorze wartości instrumentalnych służących osiąganiu celów istotnie częściej preferowane były natomiast wartości związane z samowystarczalnością, zaś znacząco rzadziej wartości obejmujące kooperację interpersonalną. Podobny układ preferencyjny odnotowany został we wcześniejszych szwedzkich i amerykańskich badaniach nad uwikłaniem w przestępczość [za: Carroll i in. 1997]. Deklarowane przez recydywistów wartości, podobnie jak w polskich badaniach cytowanych wyżej oraz przeprowadzonych przez Katarzynę Ziomek-Michalak [2005], są zbliżone do wartości deklarowanych przez ogół społeczeństwa. Wyniki badań Niewiadomskiej i Chwaszcz [2010] wskazują, że osoby podejmujące działalność 
przestępczą, w większym stopniu niż osoby nienaruszające prawa, przywiązują wagę do celów związanych z niezależnością i wolnością. Badania ujawniły także korelację między niskim nasileniem kryzysu wartościowania (wskaźniki: poczucie realizowania wartości, zdolność do porządkowania wartości, integracja wartościowania, doświadczanie posiadania wartości) a wysokim poziomem osobistego przystosowania oraz niskim nasileniem przeżywanych problemów psychologicznych przez byłych więźniów. Nie wykryto przy tym istotnych związków między osobowościową orientacją wartościującą a relacjami rodzinnymi i pozarodzinnymi, stanowiącymi dwa wymiary osobistego przystosowania byłych więźniów.

Przeprowadzone przeze mnie badania nad wykluczeniem społecznym osób powracających do przestępstw wskutek porażki readaptacyjnej, rozpatrywanej w aspekcie aksjologicznym i będące częścią prezentowanego w książce projektu badawczego [Nowak 2017], wskazują natomiast na generalną zgodność hierarchii wartości badanych recydywistów z hierarchią wartości osób przystosowanych. $\mathrm{W}$ obu grupach preferowane są bowiem wartości związane z jakością relacji interpersonalnych i kooperacją interpersonalną. Jednakże badani recydywiści zdecydowanie rzadziej niż osoby przystosowane preferują wartości związane z jakością życia społecznego, religijnego oraz kreujące sferę samowystarczalności. Jest to wynik wskazujący na spójność z wynikiem badań Ziomek-Michalak, ale na częściową rozbieżność z wynikami Niewiadomskiej i Chwaszcz [2010]. Analizy badawcze wskazują także na to, że w większości przypadków wartości deklarowane przez badanych recydywistów są przez nich realizowane, choć w wielu przypadkach odnotowano też znaczące, a czasem wręcz zasadnicze rozbieżności. W grupie wartości ostatecznych dominujące były te, które wiążą się z bezpieczeństwem rodziny, miłością i dostatnim życiem. Z jednej strony można je potraktować jako wskaźnik tęsknoty osadzonych za odseparowaną od nich rodziną, z drugiej zaś jako cel związany z dążeniem do stabilizacji życiowej. W zestawieniu wartości instrumentalnych wskazujących na sposoby osiągania celów wysokie miejsce zajęła natomiast wartość „bycie odważnym”, co może wskazywać na samowystarczalność lub preferowanie aktywności przekraczającej normy prawne i społeczne [Nowak 2017]. Tym bardziej, że jak wykazała R. Szczepanik [2015], zarządzanie konfliktem wartości (pozytywnych i negatywnych) służy recydywistom do operowania argumentacją neutralizacji zachowania przestępczego, a wartości identyfikowane przez nich jako uniwersalne wykorzystywane są w procesie negocjowania własnego wizerunku z personelem więziennym.

W cytowanym badaniu [Nowak 2017] podjęłam także próbę segmentacji wartości z zastosowaniem metody „k-średnich”, oddzielnie dla zestawu wartości ostatecznych i instrumentalnych. Średnie unormowanych rang zostały wyliczone w ramach danej grupy osób przypisanych do danej hierarchii wartości. Wyłoniono dwa segmenty (podgrupy recydywistów) zawierające zbliżony zestaw celów (wartości ostatecznych) oraz jeden segment z hierarchią odwrotną (schemat 2).

W odniesieniu do wartości instrumentalnych (sposobów osiągania celów), wyodrębniono natomiast pięć nieznacznie zróżnicowanych uporządkowań (schemat 3). 


\begin{tabular}{|c|}
\hline $\begin{array}{c}\text { Segmenty } \\
\text { (podgrupy } \\
\text { recydywistów) }\end{array}$ \\
\hline podgrupa I \\
\hline podgrupa II \\
(hierarchia zbliżona \\
do układu \\
w podgrupie I) \\
\hline podgrupa III \\
(hierarchia odwrotna \\
do układu \\
w podgrupie I) \\
\hline
\end{tabular}

Schemat 2. Segmentacja wartości ostatecznych Źródło: opracowanie własne.

\section{Wartości najwyżej cenione}

bezpieczeństwo, wolność, dojrzała miłość, dostatnie życie, szczęście, poczucie własnej wartości

bezpieczeństwo rodziny, dojrzała miłość, dostatnie życie, mądrość, poczucie własnej wartości

uznanie społeczne, zbawienie, życie pełne wrażeń, świat piękna, pokój na świecie

\section{Wartości \\ najniżej cenione}

uznanie społeczne, zbawienie, życie pełne wrażeń, świat piękna, pokój na świecie

uznanie społeczne, wolność, życie pełne wrażeń, świat piękna, przyjemność

\section{bezpieczeństwo rodziny, wolność, dojrzała miłość, dostatnie życie, poczucie dokonania}

\begin{tabular}{|c|c|c|}
\hline $\begin{array}{l}\text { Segmenty } \\
\text { (podgrupy } \\
\text { recydywistów) }\end{array}$ & $\begin{array}{c}\text { Wartości } \\
\text { najwyżej cenione }\end{array}$ & $\begin{array}{c}\text { Wartości } \\
\text { najniżej cenione }\end{array}$ \\
\hline podgrupa I & $\begin{array}{c}\text { wybaczający, odważny, } \\
\text { uzdolniony, niezależny, } \\
\text { uczciwy, czysty }\end{array}$ & $\begin{array}{l}\text { odpowiedzialny, intelektualista, } \\
\text { o szerokich horyzontach, } \\
\text { obdarzony wyobraźnią, ambitny }\end{array}$ \\
\hline podgrupa II & $\begin{array}{l}\text { ambitny, opanowany, kochający, } \\
\text { czysty, uprzejmy, pogodny }\end{array}$ & $\begin{array}{c}\text { intelektualista, uczciwy, } \\
\text { wybaczający, posłuszny, } \\
\text { uzdolniony }\end{array}$ \\
\hline podgrupa III & $\begin{array}{l}\text { kochający, odpowiedzialny, } \\
\text { odważny, pogodny }\end{array}$ & $\begin{array}{l}\text { obdarzony wyobraźnią, } \\
\text { ambitny, czysty }\end{array}$ \\
\hline podgrupa IV & $\begin{array}{l}\text { ambitny, odważny, niezależny, } \\
\text { czysty, kochający }\end{array}$ & $\begin{array}{l}\text { wybaczający, uzdolniony, } \\
\text { posłuszny, uprzejmy }\end{array}$ \\
\hline podgrupa $\mathrm{V}$ & $\begin{array}{l}\text { ambitny, odpowiedzialny, } \\
\text { niezależny, kochający, pogodny }\end{array}$ & $\begin{array}{l}\text { intelektualista, } \\
\text { o szerokich horyzontach, } \\
\text { obdarzony wyobraźnią, } \\
\text { logiczny, czysty }\end{array}$ \\
\hline
\end{tabular}

Schemat 3. Segmentacja wartości instrumentalnych Źródło: opracowanie własne. 
Należy podkreślić, że do segmentacji wartości trzeba podchodzić ostrożnie z uwagi na to, że została ona przeprowadzona w sposób nieco arbitralny. Dokonane podziały mogą jednak stanowić materiał bazowy do dalszych pogłębionych analiz o charakterze jakościowym. Praca nad modyfikacją przekonań osób skazanych o sobie i dotychczasowym sposobie postępowania wydaje się punktem wyjścia do właściwych oddziaływań resocjalizacyjnych.

\subsubsection{Poczucie umiejscowienia kontroli}

W badaniach nad porażką readaptacyjną aspekt związany z umiejscowieniem kontroli (wewnętrzna versus zewnętrzna) uznano za ważny z uwagi na to, że poczucie kontroli w dużym stopniu determinuje zachowania człowieka oraz informuje o stopniu jego przystosowania się i radzenia sobie w różnych sytuacjach. Ten wymiar osobowości jest względnie trwały i krystalizuje się poprzez doświadczanie rzeczywistości. Określa on stopień postrzegania przez człowieka własnych działań jako efektu jego własnej aktywności lub przeciwnie, jako skutku zaistnienia określonych okoliczności zewnętrznych lub sytuacji przypadkowych [Wosińska 2004, s. 83].

Kształtowanie jednego z biegunów poczucia kontroli rozpoczyna się dość wcześnie. Wiąże się to z rozwojem poznawczym oraz społeczno-emocjonalnym. Oprócz rozwoju indywidualnego, opierającego się na uczeniu w rozumieniu psychologicznym (gromadzeniu doświadczeń), poczucie lokalizacji kontroli determinowane jest oddziaływaniami intencjonalnymi, a głównie metodami wychowawczymi oraz technikami kształcenia stosowanymi w trakcie edukacji szkolnej.

Osoby mające wewnętrzne poczucie kontroli, tzw. LOC wewnętrzny, są bardziej odporne na stres, sprawne i efektywne oraz dojrzalsze emocjonalnie i społecznie niż osoby z LOC zewnętrznym. Cechują je także: wyższy poziom samooceny, wyższy stopień samoakceptacji i samodzielności, postrzeganie sukcesów i porażek jako skutków własnych działań [Nowicki, Strickland 1973, s. 40] oraz bardziej realny obraz siebie [Maqsud 1980].

Środowisko nie wptywało na moje wybory. Żaden z kumpli mnie nie namawiat, ale sam rzadko kradtem, zawsze ktoś mi w tym pomagat. Łatwiej byto ukraść, niż zarobić. Nie zszedtem nagle na zła drogę za czyjąś namowa, to trwało latami. [L.O. - 37 lat, duże miasto, wykształcenie zawodowe, recydywista trzykrotny, wyroki skazujące za kradzieże, kradzież $\mathrm{z}$ włamaniem oraz rozbój]

Akceptuję siebie. Swoich poczynań nie akceptuję, żatuję tego, bo za gtupie rzeczy, za pierdoty siedze tutaj. Myślę, że to co się wydarzyto, będzie miało wpływ na mnie, będe próbowat, to jakoś zmienić, siebie zmienić. [B.P. - 56 lat, średnie miasto, wykształcenie zawodowe, recydywista dwukrotny — wyroki skazujące za kradzieże, rozbój oraz rozprowadzanie narkotyków] 
Osoby z LOC zewnętrznym są konformistyczne, przekonane, że ich los jest dziełem przypadku, splotu okoliczności, efektem działania innych ludzi lub instytucji. Sprawia to, że są bardziej zależne od innych osób, mają niższą samoocenę i problemy w radzeniu sobie. Odczuwają trudności w poszukiwaniu informacji pozwalających przezwyciężyć trudne sytuacje życiowe i często stają się bezradne. Czekają, aż coś się wydarzy, zamiast zmierzać do zmiany lub rozwiązania sytuacji problemowej. Postrzegają świat jako miejsce im nieprzyjazne i charakteryzują się wyższym poczuciem niepokoju. W sytuacjach kryzysowych mogą zachowywać się dwubiegunowo: wykazują bierność lub stosują strategie unikowe [Horner 1996]. Reagują często agresją lub autoagresją oraz wykazują skłonności do zachowań konfliktowych [Borecka-Bernat 2014]. Osoby z LOC zewnętrznym są nieaktywne społecznie, skłonne do uprzedzeń, stereotypowe $\mathrm{w}$ działaniach i sterowane przez innych, ale też sterujące innymi. Są jednak podatne na perswazję oraz kierowanie ich rozwojem i postępowaniem z uwagi na niskie poczucie własnej wartości i wysokie poczucie lęku [Krasowicz, Kurzyp-Wojnarska 1987].

Wyniki przeprowadzonych przeze mnie eksploracji badawczych [Nowak 2017b] wskazują, że recydywistów penitencjarnych cechuje najczęściej zewnętrzne poczucie kontroli. Jest to wynik spójny z wynikami badań innych autorów [Belniak 2014; Strzelczyk 2010]. Na kształtowanie się zewnątrzsterowności u osadzonych ma niewątpliwie wpływ sytuacja więzienna, w której są oni zmuszeni do respektowania sytuacji kontroli, podporządkowania się, a to z kolei skutkuje obniżonym poczuciem sprawstwa.

W trakcie odbywania kary izolacji u osadzonych następuje spadek nasilenia poczucia kontroli wewnętrznej [Turecka 2005], gdyż życie więzienne sprzyja kształtowaniu się postaw charakterystycznych dla LOC zewnętrznego, umożliwiającego lepsze przystosowanie się do warunków izolacyjnych, a tym samym zabezpieczającego pozytywną samoocenę.

Najgorzej wkurza mnie to, że jestem skazywany bez żadnych dowodów, albo mam dowody podrzucane. Skoro policjant jest przedstawicielem prawa, to niech tego prawa przestrzega. Ja nie przestrzegam, bo ja jestem przestępca. Kradnę, trudno, ale on powinien prawa przestrzegać. Policja wie, że ja przez jakiś czas robię to czy to, ale nie potrafi mi tego udowodnić. No i co, zatrzymuja mnie i podrzucaja mi kilogram amfetaminy, że to jest moje, chociaż tam w ogóle nie było moich odcisków palców. Ja mam teraz, w tym wyroku, jeden rok na lewo, bo w ogóle takiego przestęstwa nie byto. Brat mój siedział dwa lata na lewo za dwa artykuty $i$ nie to, że ktoś zrobit przestepstwo i poszto na niego, tylko takiego przestępstwa w ogóle nie było. I to mnie najgorzej wkurza. On nie wierzyt, bo ja wcześniej siedziałem od niego i mówitem mu, ze takie sytuacje są. Zawsze przynajmniej jeden na celi się zdarzy, co siedzi na lewo. Brat mi nie wierzyt, dopóki sam nie poszedt siedzieć. [A.T. — 39 lat, wykształcenie podstawowe, mieszkaniec średniego miasta, recydywista czterokrotny, wyroki skazujące za kradzieże] 
Nie można jednak jednoznacznie stwierdzić, że zewnętrzne umiejscowienie kontroli zostało ukształtowane w wyniku długotrwałego lub częstego ich przebywania w środowisku zamkniętym. Ustalono jedynie, że na obniżone poczucie sprawstwa wpływa doświadczanie sytuacji trudnych przed i podczas pobytu w zakładzie karnym.

Skazani zewnątrzesterowni przejawiają więcej objawów niedostosowania emocjonalnego i wyższy poziom lęku od skazanych wewnątrzsterownych [Belniak 2014]. W tym zakresie nie występują różnice pomiędzy recydywistami wielokrotnymi a jednokrotnymi [Bowen, Gilchrist, Beech 2005].

Badania przeprowadzone przez L. Contreras, V. Molinę i M. Del Carmen Cano [2011] dowiodły z kolei, że zewnętrzna lokalizacja kontroli pełni funkcję pośredniczącą pomiędzy powrotnością do przestępstwa a objawami nieprzystosowania (niski poziom kompetencji społecznych, problemy w radzeniu sobie ze stresem, słaba samokontrola, niska tolerancja na frustrację) oraz dysfunkcją/patologią środowiska rodzinnego (m.in. rozpad rodziny, uzależnienia, niskie dochody).

Na rozwój zewnętrznego poczucia kontroli znaczący wpływ mają czynniki środowiskowe, szczególnie rodzinne: autokratyczny styl wychowania, rygor oraz zmienność wymagań stawianych przez rodziców lub wychowawców. Wpływ na krystalizację zewnątrzsterowności mogą mieć także negatywne warunki wychowania rodzinnego (bezrobocie, ubóstwo, choroba alkoholowa w rodzinie oraz bezradność lub bierność rodziców w obliczu narastających problemów), a zwłaszcza rygor oraz zmienność wymagań stawianych przez rodziców [Nowicki, Strickland, Horner 1973], określane jako oddziaływanie niekonsekwentne.

W przeprowadzonym przeze mnie badaniu [Nowak 2017b] interesujący okazał się wynik informujący o braku istotnych związków między umiejscowieniem kontroli a wielokrotnością recydywy. Świadczyć to może o pomijaniu lub zaniedbywaniu tego aspektu w oddziaływaniach resocjalizujących oraz we wspomaganiu readaptacyjnym. Związki istotne wykryto natomiast między lokalizacją kontroli a typem zakładu karnego. Otóż odnotowano czterokrotnie większy odsetek recydywistów z wewnętrznym poczuciem umiejscowienia kontroli, osadzonych w zakładzie zamkniętym, w porównaniu z osadzonymi w zakładzie półotwartym. Prawdopodobnie spowodowane jest to większym nasileniem aktywności podkulturowej w zakładach typu zamkniętego. Taka interpretacja uzyskanego wyniku wydaje się właściwa w świetle badania przeprowadzonego przez Katarzynę Belniak [2014], które wykazało, że osoby włączone do podkultur więziennych wykazują bowiem większy stopień wewnętrznego poczucia kontroli.

\subsubsection{Poczucie stygmatyzacji a samoocena osób powracających do przestępstwa}

W świetle teorii interakcyjnych każde społeczeństwo stosuje własne sposoby kategoryzowania swoich członków. Opracowuje zestawy atrybutów typowych i naturalnych dla przedstawicieli lokujących się w każdej kategorii [Goffman 2007]. Każdej jednostce i grupie społecznej stawiane są normatywne oczekiwania 
odnośnie do tożsamości społecznej i podejmowania społecznych interakcji. Osoby wykraczające poza ustanowione przewidywania obarczane są piętnem/ stygmatem osoby odmiennej, niepełnowartościowej lub niebezpiecznej i niepożądanej społecznie. Stygmat jest nie tylko cechą dyskredytującą daną osobę, ale także zespołem przekonań na temat osób ją posiadających [Heatherton, Kleck, Hebl 2008, s. 75]. Jest efektem dysonansu poznawczego między tożsamością oczekiwaną, z atrybutami i cechami traktowanymi jako właściwe i wymagane w danej grupie a tożsamością rzeczywistą [Goffman 2007; Kudlińska 2011]. Pełniąc funkcję regulującą, stygmat społeczny staje się w ten sposób narzędziem umożliwiającym budowanie i podtrzymywanie hierarchii społecznej.

Mechanizmy uprzedzeń, dyskryminacji i wykluczenia społecznego wyjaśnia między innymi teoria naznaczania (labeling theory), wywodząca się z myśli George'a H. Meada i symbolicznego interakcjonizmu. Przedstawiciele tego kierunku uważają, że dewiacja jest kreowana przez społeczeństwo i stanowczo przeciwstawiają się założeniu, że zachowania ludzkie są aktami dewiacji z uwagi na immanentne i obiektywne cechy szkodzące społeczeństwu. Rozumowanie to prowadzi do konstatacji, że dewiacja jest konsekwencją stosowania norm i sankcji wobec sprawcy czynu nieaprobowanego społecznie. Zachowaniem dewiacyjnym jest zatem zachowanie napiętnowane/naznaczone przez innych ludzi [Becker 1963, s. 9]. Dewiantem staje się ten, kto w reakcji na określone zachowanie zostaje nazwany ,innym” przez jednostki lub grupy dysponujące społeczną siłą [Pospiszyl 2012].

$\mathrm{O}$ interpretacjach zachowań innych ludzi, a w konsekwencji tworzeniu pewnych kategorii zachowań traktowanych jako dewiacyjne i prawnie/społecznie sankcjonowane, decydują interakcje społeczne, a nie cechy osobowościowe, zaburzenia charakterologiczne czy psychiczne. Zatem to właśnie bycie naznaczonym jest wspólną, identyfikacyjną cechą wszystkich dewiantów, wraz z wszelkimi wynikającymi z tego faktu doświadczeniami [Kitsuse 1962, s. 253].

W teorii naznaczania społecznego rozważaniom nie podlega jednak dewiacja pierwotna, zdefiniowana po raz pierwszy przez Edwina Lemerta [1967], wieloprzyczynowa i wykreowana różnorakimi społeczno-kulturowymi zdarzeniami i/lub warunkowana psychologicznie lub fizjologicznie, ale dewiacja wtórna. Lemert określił ją jako odpowiedź dewianta pierwotnego na problemy moralne związane z kontrolą społeczną, wygenerowane stygmatyzacją i sankcjami. Problemy te wywołują zmianę w strukturze psychicznej, prowadzą do specyficznej reorganizacji dotychczasowych ról społecznych oraz postrzegania siebie, wpływając znacząco na specyfikę organizacji życia dewianta wtórnego, skupionego na fakcie własnej dewiacji. Negatywne naznaczenie przez otoczenie społeczne i przypisanie roli dewianta sprawia, że napiętnowany człowiek zaczyna postrzegać siebie $\mathrm{w}$ takich samych kategoriach, w jakich postrzega go grupa odniesienia, a w rezultacie przyjmuje naznaczenie i jest przekonany, że jest inny, gorszy od pozostałych, że w istocie rzeczy jest dewiantem. Co więcej, jeśli w dalszym ciągu osoba raz naznaczona podlega monitorowaniu społecznemu i nadal przejawia zachowania dewiacyjne, to wywołuje wzmocnione tym 
faktem negatywne reakcje społeczne, które ugruntowują w niej przekonanie o byciu dewiantem. I tu rozpoczyna się swoisty proces: wzmożone sankcje skłaniają do coraz większego zaangażowania dewiacyjnego i budowania rzeczywistej roli dewianta, co prowadzi do rozpoczęcia kariery przestępczej.

Proces ponownego naznaczania i reakcji otoczenia jest czteroetapowy [Simmons 1965, Schur 1971]. Pierwszy etap zapoczątkowuje sytuacja, w której osoba uznana za dewianta zaczyna być postrzegana stereotypowo jako dopuszczająca się czynów dewiacyjnych określonego rodzaju. Etap drugi to automatyczne uruchomienie stereotypu w odpowiedzi na ponowną identyfikację dewianta pierwotnego jako sprawcy takiego samego lub innego zachowania dewiacyjnego. Kolejny etap (trzeci) to interpretacja retrospektywna, „olśnienie” związane z ujawnieniem dewiacji i reinterpretacją postrzegania przez otoczenie przeszłych zachowań osoby naznaczonej w świetle stereotypu, pomimo tego, że nie były one przedtem traktowane jako dewiacyjne. Ujawniony fakt dewiacji zostaje uznany jako norma w zachowaniach osoby z ujawnioną dewiacją (etap końcowy — czwarty).

W świetle teorii stygmatyzacji dewiacja ma charakter relatywny, gdyż kategorie normy i dewiacyjnych etykiet zmieniają się w czasie oraz w przestrzeni społeczno-kulturowej [Major, O'Brien 2005; Goffman 2007]. Stygmatyzacja jako proces jest także zmienna historycznie, ma różne oblicza oraz szerokie spektrum piętnowanych cech. Oprócz stygmatu fizycznego (deformacje ciała) i plemiennego (rasa, narodowość, wyznanie) E. Goffman [2007] wyróżnia stygmat charakteru, który dotyczy między innymi osób skazanych — przestępców. Istotą tego rodzaju piętna jest to, że wynika ono ze zdarzeń biograficznych będących udziałem osób, które wygenerowały u skazanego cechy negatywne (m.in. słabą wolę, nieopanowanie, nieumiejętność konstruktywnego radzenia sobie w sytuacjach trudnych). Nadanie stygmatu wiąże się w tym przypadku z dyskwalifikacją osoby nim obdarzonej i uznania jej za mniej wartościową od innych lub całkowicie bezwartościową wskutek wyłącznej koncentracji na elemencie negatywnie naznaczającym i bezwzględnego pominięcia jej cech pozytywnych [Oyserman 2001; Major, O’Brien 2005; Czywkin 2007], czego konsekwencją jest społeczne wykluczenie. W percepcji społecznej przestępcy są bowiem postrzegani jako osoby zagrażające, wobec których należy zachować daleko idącą ostrożność i nieufność, co przejawia się ich odrzuceniem a priori [Heatherton, Kleck, Habl 2008]. Wskazują na to wyniki wielu analiz badawczych, które ujawniają na przykład nasilenie zjawiska stygmatyzacji w sąsiedztwie byłych więźniów [Siemaszko 1993; Niewiadomska 2007] oraz niechęć wielu pracodawców do zatrudniania osób z przestępczą przeszłością [Nowak 2019a]. Pozbycie się przestępczego piętna po zakończeniu kary pozbawienia wolności jest niezwykle trudne, a nieudane próby skutkują negatywną readaptacją społeczną i ponownym uwikłaniem się w przestępczość [Nowak 2017a, Ambrozik 2007; Szymanowska 2003].

Pierwszy raz po opuszczeniu z.k. wróciłem do mamy, gdzie liczyłem na podjęcie jakiejkolwiek pracy, która znaleźć jest bardzo trudno ze względu na karalność. Ja jednak miałem to szczęście, że zostałem przyjęty do 
pracy $w$ dużym markecie i miatem tam układać towar na pótkach każdego dnia od 4.00 rano za niewielkie wynagrodzenie. Praca ta była dla mnie duża szansa na życie zgodne z normami społecznymi, ale czas oraz podejście pracodawcy i przełożonych do mnie byt nie do zaakceptowania. Dlaczego? Bytem traktowany z pogarda, lekceważono moje prośby, przeszłość moja więzienna była mi wytykana przez pracodawców prawie codziennie. Każde braki towaru byty sprawdzane w mojej szafce - czy może przez przypadek nie jest on u byłego skazanego. Cierpliwość i spokój kończa się dość szybko i los znów pokierowat mnie w zła stronę. Wierze jednak, że teraz już mój pobyt w więzieniu jest ostatnim. [E.P. 42 lata, rozwiedziony, wykształcenie zawodowe, mieszkaniec dużego miasta, recydywista dwukrotny, wyroki skazujące za usiłowanie gwałtu, gwałt i oszustwo]

Stygmatyzacja nie jest jednak jedyną przyczyną zaburzeń w wychodzeniu z przestępczości. Problemy związane z ponowną adaptacją byłych więźniów do warunków wolnościowych są bowiem wieloczynnikowo warunkowane. Jest to między innymi także stygmatyzująca kontrola wymiaru sprawiedliwości i instytucji porządku publicznego. Ujawniona etykieta przestępcy skutkuje silnymi, negatywnymi reakcjami społecznymi i daje organom kontroli społecznej asumpt do sprawdzenia poczynań osoby skazanej za podobne przewinienia. Na negatywne nastawienie organów ścigania do osób skazanych wskazują najczęściej recydywiści mieszkający w małych miastach, którzy twierdzą, że niemal każdy czyn przestępczy, do którego dochodzi w okolicy ich zamieszkania, jest im automatycznie przypisywany przez policjantów prowadzących dochodzenie w danej sprawie. Taki stan rzeczy utrwala $\mathrm{w}$ ich mniemaniu nadane im wcześniej piętno społeczne, zniechęca do zmiany i utrudnia wysiłki readaptacyjne. Bez względu na wykazywaną chęć poprawy już zawsze będą nosić piętno kryminalisty, piętno jaskrawe szczególnie w niewielkiej społeczności lokalnej.

Koledzy to byli tacy jak ja, a może to ja bytem gorszy od nich... Nieważne, bo ludzie i policja i tak przypisuja mi o wiele więcej rzeczy, niż rzeczywiście zrobilem. Przypuśćmy, że wychodzę dzisiaj z więzienia, to w miasteczku, w którym mieszkam, od dnia kiedy ja wyjdę na wolność, wszystko spada na mnie, chociaz ja, np. jedna dziesiata tego zrobitem. By mnie wsadzić do więzienia, policjanci musza mieć dowody, a oni już mnie zna$j a$, więc wiedza, że na mnie nic nie wymusza, to i na ,dołek" mnie już nie zabieraja. Pierwszy raz jak pojechałem na komendę za dzieciaka, to bytem bity po to, żebym się przyznat. Drugi raz się nie przyznatem, to od tego czasu już mnie nie zabieraja, chyba że na komendę, gdzie mnie nie znaja i oni też próbuja wymusić ode mnie zeznania, ale ja już w ogóle nie rozmawiam z policją. [E.P. - 32 lata, kawaler, wykształcenie zawodowe, mieszkaniec małego miasta, recydywista trzykrotny, wyroki skazujące za kradzieże] 
Równie często badani wskazują na rzekome błędy popełniane w dochodzeniu policyjnym czy procedowaniu sądowym, na brak dostępu do adwokata lub też środków na zatrudnienie doświadczonego obrońcy.

Dwadzieścia lat temu popetnitem przestępstwa, za które zostałem stusznie skazany i odsiedziatem swoje. Od tamtej pory starałem się żyć zgodnie z normami społecznymi, a mój powrót do więzienia jest efektem wyłacznie błędów sądowych. Policja wiązała mnie z przestępstwami podobnymi do popetnionych przeze mnie wcześniej. Nie umiatem się bronić, a i alibi też nie miatem... Teraz siedze już czwarty raz $i$ chyba za stary już jestem na ułożenie sobie życia na wolności, zwłaszcza, że odsiedzié́ jeszcze muszę 8 lat. [K.L. - 53 lata, rozwiedziony, mieszkaniec małego miasta, wykształcenie średnie, recydywista czterokrotny, wyroki skazujące za oszustwa i kradzieże]

Symptomatyczne jest użalanie się recydywistów z dużych miast na opieszałość polskich sądów. W oczekiwaniu na wyrok są przez długi czas niepewni jutra i w żaden sposób nie mogą liczyć na ustabilizowanie sytuacji życiowej. Zdają sobie bowiem sprawę, że muszą brać pod uwagę wyrok skazujący, co w dużym stopniu zaburza proces konstruktywnego myślenia o sobie, zmianie postaw i zachowań na akceptowane społecznie, o własnej przyszłości i związanej z tym sytuacji osób im bliskich.

To, że obecnie przebywam w więzieniu, wynikło z powodu niekompetencji i opieszałości sądów. Wyroki, które obecnie odbywam, sq za przestępstwa popetnione przeze mnie 15 lat temu. Przez te 15 lat staratem się żyć zgodnie z regułami i normami społecznymi, ale co parę lat bytem zatrzymywany i osadzany, przez co nie mogłem normalnie ułożyć sobie życia prywatnego. Myślę, iż teraz, po wyjściu na wolność wyjadę z kraju, no nie wiem gdzie..., no, gdzie oczy poniosa i skończy się moja przygoda z prawem polskim i sadami, i chociaż pod koniec życia będe mógt normalnie funkcjonować w spoteczeństwie [P.M. — 49 lat, rozwiedziony, mieszkaniec dużego miasta, wykształcenie zawodowe, recydywista dwukrotny, wyroki skazujące za usiłowanie gwałtu, kazirodztwo i oszustwo]

Odrzucenie, poczucie wyalienowania, a w rezultacie fiasko wysiłków readaptacyjnych prowadzą skazanych ku ponownemu poddaniu się wpływom dewiacyjnego otoczenia i skutkują dalszym rozwojem kariery przestępczej [Becker 1963; Urban 2005]. Jest to również konsekwencja powrotu osób wychodzących na wolność do ich pierwotnego środowiska życia. Jedni z nich, nie radząc sobie w nowych realiach społecznych, w ostateczności szukają pomocy i wsparcia u dawnych, wykolejonych przestępczo kolegów. Inni zaś, po wyjściu na wolność nadal poszukują silnych wrażeń, wchodzą w zastane środowisko przestępcze i przekraczają normy prawne, moralne i obyczajowe. 
Wśród przyczyn recydywy wskazanych przez badanych recydywistów [Nowak 2017a] stygmatyzacja ulokowana została jednak dopiero na czwartym miejscu. Ponad połowa z nich odczuwa piętno społeczne niezależnie od wielkości środowiska życia na wolności. Pomijając jednak negatywny wynik statystyczny, należy podkreślić, że — jak już wcześniej wskazano — niechęć społeczności lokalnej odczuwają najczęściej recydywiści z enklaw społecznych małych oraz średniej wielkości. Mieszkańcy dużych miast podlegają natomiast słabej kontroli społecznej, gdyż ich identyfikacja i monitorowanie poczynań w kilkusettysięcznej zbiorowości są znacznie utrudnione. Jest to wynik spójny z wynikiem badania odnoszącego się do trudności skazanych w uzyskaniu zatrudnienia po wyjściu na wolność. Po ujawnieniu kryminalnej przeszłości nieprzychylność pracodawców odczuwa prawie połowa badanych recydywistów z małych miast oraz ponad połowa z miast średniej wielkości. Dość interesujący okazał się wynik dotyczący stygmatyzacji społecznej rodzin badanych recydywistów. Otóż niezależnie od miejsca zamieszkania, w większości przypadków ( $2 / 3$ ogółu badanych) nie mają oni poczucia napiętnowania - z powodu ich pobytów $\mathrm{w}$ więzieniu, często wielokrotnych — ani ich rodzin pochodzenia, ani rodzin własnych. Być może jest to efekt tolerancji środowiskowej lub oswojenia się z faktem, iż coraz więcej rodzin trapią liczne problemy różnorakiej natury.

Ostracyzmowi społecznemu podlegają (częściej niż w innych rodzajach środowisk) wiejskie rodziny wieloproblemowe, w tym dotknięte problemem penitencjarnym [Nowak 2011]. Wskazuje to na efekt nasilonej stygmatyzacji w niewielkich liczebnie środowiskach wiejskich, gdzie wszelkie przejawy inności spotykają się z silną dezaprobatą, a często odrzuceniem ich przez mieszkańców.

Wyżej opisany stan rzeczy powiązany jest z wynikami samooceny dokonanej przez badanych recydywistów. Należy przy tym pamiętać, że przekonania wartościujące na temat siebie są afektywne - wyzwalają pozytywne lub negatywne emocje. Mieszkańcy wsi zdecydowanie częściej niż mieszkańcy miast oceniają siebie negatywnie, a poziom ich samooceny jest generalnie niski. Postrzegają siebie najczęściej jako osoby o niskich możliwościach, mało wartościowe, przegrane życiowo, nieśmiałe, mające problemy w relacjach społecznych [Nowak 2017a].

Rzeczywisty obraz siebie jest znaczący w procesie adaptacji społecznej, gdyż samoocena jest zmienną określającą zachowanie człowieka, a zarazem jednym z ważnych predyktorów tworzenia spójnej koncepcji siebie [Wojciszke 2011]. $\mathrm{W}$ prezentowanym badaniu przyjęto, że samoocena jest indywidualną oceną przymiotów osobistych, kształtowaną w ramach socjalizacji pierwotnej i odnoszącą się do poczucia własnej wartości, poczucia samoakceptacji oraz informacji zwrotnych pozyskiwanych z otoczenia społecznego [Kavas 2009]. Poziom samooceny ustalany jest na podstawie samoopisu. Samoocena wysoka świadczy o pozytywnym wartościowaniu siebie, zaś niska oznacza stosunek do siebie umiarkowanie pozytywny. Poziom samooceny powiązany jest z poczuciem sprawstwa, które odgrywa znaczącą rolę w radzeniu sobie w sytuacjach trudnych. Stąd też nadmiernie niska samoocena utrudnia jednostce radzenie sobie 
z problemami, a w przypadku ich nawarstwienia i niemożności ich rozwiązania zwiększa tendencję do stosowania strategii ucieczkowych. Najczęściej jest to zażywanie środków psychoaktywnych lub podejmowanie innych zachowań ryzykownych, takich jak autoagresja, agresja lub czyny przestępcze. W przestrzeni społecznej zauważalna jest jednak powszechna tendencja do utrzymywania samooceny na wysokim poziomie. Zdarza się także, że samoocena bywa zawyżana. Zabieg ten ma wówczas charakter manipulacyjny.

W prezentowanym badaniu dostrzec można wyraźną tendencję do zawyżania samooceny przez osoby badane. Otóż zdecydowana większość badanych recydywistów postrzega siebie pozytywnie - jako osoby nieposiadające zahamowań w nawiązywaniu bliższych relacji interpersonalnych, komunikatywne, otwarte na innych. Prawdopodobnie wynika to z faktu, iż w sytuacji opresyjnej, a do takiej należy pobyt w zakładzie karnym, dotychczasowy, dobry wizerunek własny osoby skazanej staje się zagrożony, a w związku z tym osadzeni uruchamiają mechanizmy obronne, prowadzące do utrwalenia pozytywnego obrazu siebie. Pozwalają one na redukcję lęku i utrzymanie dobrego mniemania o sobie, chronią przed depresją oraz utratą motywacji do działania. Zjawisko to wyjaśnia Harry S. Sullivan [1953], wskazując na wewnętrzny mechanizm samoregulacji (self-system), który eliminuje wszelkie informacje mogące wpłynąć destrukcyjnie na dotąd pozytywny obraz siebie.

Wyniki badania wskazują, że z im większej miejscowości pochodzą osoby badane, tym są bardziej pewne siebie w podejmowanych interakcjach, wprawdzie licznych, ale zwykle krótkotrwałych i powierzchownych [Nowak 2017a].

Zawsze bytem i nadal jestem osoba towarzyska. Miałem sporo kolegów, ale tylko jednego przyjaciela. Teraz niestety urwat się z nim kontakt... $Z$ dziewczynami jest podobnie - jak tylko jakaś dziewczynę bardziej polubitem, to przyznawatem się do odsiadek $i$ wtedy ja tracitem, bo nie chciata już, ze mna się spotykać. Teraz jestem sam. Jak wychodze z więzienia, to nawiazuje sporo kontaktów, ale tak naprawdę nie zaprzyjaźniam się już $z$ nikim, nie opowiadam o sobie, bo i po co? Ludzie sa mi potrzebni do załatwiania różnych spraw, a jak już pomoga, to spadam i szukam innych. [M.L. - 32 lata, kawaler, wykształcenie gimnazjalne, mieszkaniec dużego miasta, recydywista dwukrotny, wyroki skazujące za rozbój, kradzież z włamaniem, groźby karalne i pobicie]

Mechanizm samoregulacji pozwala wyjaśnić także wysoki poziom samooceny badanych recydywistów, pomimo ich ewidentnych niedoskonałości osobowościowych, moralnych i charakterologicznych czy niskich kompetencji komunikacyjnych, społecznych i zawodowych lub też ich braku. W przypadku osób izolowanych podwyższanie samooceny jest formą zachowania przystosowawczego do warunków więziennych. Samoocena ma wówczas charakter chwilowy i zmienny w zależności od sytuacji [Fila-Jankowska 2009]. Wyniki badania przeprowadzonego przez Anetę Jaworską [2016] wskazują natomiast na 
rolę samooceny w zdolności konstruowania przez osoby skazane pozytywnych rozwojowo celów życiowych, przy czym osiąganie wychowawczych rezultatów działań twórczych utrudnia nastawienie obronne skazanych i ich skłonność do agresywnej obrony własnej samooceny.

\subsection{Społeczno-środowiskowy „kosmos” niesprawności i niemocy powrotnych}

Prezentowane w niniejszym podrozdziale wyniki badań własnych dotyczą narracji recydywistów penitencjarnych, którzy odnieśli się do statusu ekonomicznego i sytuacji materialnej rodzin pochodzenia, postaw wychowawczych rodziców, przeszłych i aktualnych kontaktów z nimi, jak również opisywali sytuację materialną rodzin własnych oraz kontakty i relacje z pozostawionymi na wolności partnerkami i dziećmi.

\subsubsection{Retrospekcyjny obraz rodziny pochodzenia}

Rodzina jako najistotniejsza forma życia społecznego, miejsce o decydującym znaczeniu w kształtowaniu osobowości człowieka oraz ośrodek przekazywania życia i kultury, jest środowiskiem podstawowym i naturalnym dla każdego wychowującego się w niej dziecka. Jest także silnym czynnikiem chroniącym je przed podejmowaniem zachowań ryzykownych i niedostosowaniem społecznym.

W przebiegu socjalizacji pierwotnej istotne są oddziaływania wychowawcze prowadzące do poczucia koherencji, czyli postrzegania przez dziecko świata jako zrozumiałego i sensownego oraz dostrzegania przez nie zasobów (wewnętrznych i zewnętrznych), umożliwiających radzenie sobie w różnych sytuacjach, $\mathrm{w}$ tym trudnych. W toku tego naturalnego treningu wykształcane są elementarne kompetencje umożliwiające sprawne i bezkolizyjne funkcjonowanie społeczne, w tym umiejętności:

- udzielania wzmocnień społecznych;

- empatii i umiejętności podejmowania ról innych ludzi, ważnych zwłaszcza w rodzinie oraz w związkach miłosnych i przyjacielskich;

- asertywności, czyli umiejętności obrony własnych praw z poszanowaniem praw innych osób;

- komunikacji werbalnej i niewerbalnej;

- umiejętności rozwiązywania problemów (istotnej zwłaszcza w przypadku częstego występowania konfliktów);

- umiejętności korzystnej autoprezentacji (szczególnie przydatnej w kontekście zawodowym). 
Wyniki badań eksplorujących omawiane zagadnienie wskazują jednak, że sytuacje ryzyka społecznego, w jakie uwikłane są dzieci wychowujące się w rodzinach głęboko dysfunkcyjnych i/lub patologicznych, skutkują ich niedostosowaniem społecznym i demoralizacją [m.in. Wysocka, Ostafińska-Molik 2014; Nowak 2011]. Dzieci te w dorosłości powielają często rodzinne dysfunkcje i patologie. Część z nich, przejmując rodzinne, antyspołeczne wzorce socjalizacyjne, wkracza na ścieżkę kariery przestępczej. Liczne analizy empiryczne wskazują, że osoby niedostosowane społecznie, zagrożone przestępczością i przestępcy posiadają wadliwe schematy poznawcze $\mathrm{w}$ zakresie postrzegania siebie, szacowania własnych możliwości i określania potrzeb, a także styl poznawczy charakteryzujący się brakiem refleksji nad konsekwencjami popełnionych czynów zabronionych, dominacją myślenia konkretnego nad abstrakcyjnym, tendencją do obwiniania innych i wskazywania na okoliczności zewnętrzne jako odpowiedzialne za zaistniałe zdarzenia. Osoby te mają również trudności z obiektywną oceną sytuacji. Cechuje je brak umiejętności wytyczania celów, ich artykułowania i osiągania. Zniekształcenia kognitywne mogą prowadzić do nastawienia antyspołecznego, silnie korelującego z recydywą przestępstw agresywnych. Skazani cechują się także znacząco niższym od osób niekaranych poziomem poczucia sensu własnej egzystencji (większe trudności w wyznaczaniu celów życiowych oraz niższa motywacja do działań intencjonalnych). Co istotne, recydywiści penitencjarni wykazują znacząco niższe nasilenie poczucia sensu życia (m.in. poczucie beznadziejności i pesymistyczna wizja własnego funkcjonowania $\mathrm{w}$ przyszłości) $\mathrm{w}$ porównaniu $\mathrm{z}$ osobami skazanymi po raz pierwszy. Wśród osadzonych recydywistów znajdują się także osoby z wysokim nasileniem poczucia sensowności (m.in. większe nasilenie sprawstwa oraz optymistyczne zorientowanie na przeszłą perspektywę czasową), które charakteryzują się tym, że są ukierunkowane na podejmowanie w przyszłości działań zgodnych z normami społecznymi. Cechuje je dążenie do samorozwoju, wysokie zaufanie do innych ludzi oraz siebie, jak również kompetencje zaradcze umożliwiające im konstruktywne przekształcanie określonych sytuacji. W ogólnym oglądzie osoby popełniające czyny przestępcze wykazują jednak tendencję do stosowania destrukcyjnych strategii zaradczych, co przejawia się między innymi w aktach agresji, okazywanej innym wrogości czy w niekontrolowanych wybuchach gniewu [za: Niewiadomska 2010, s. 33-34].

Czynniki środowiskowe mają kluczowe znaczenie w powstawaniu zaburzeń zachowania oraz przestępczości nieletnich. Badania przeprowadzone przez I. Niewiadomską, J. Chwaszcz i W. Augustynowicz [2010] wykazały, że wysoki poziom koherencji u nieletnich powiązany jest dodatnio $\mathrm{z}$ ich pozytywną readaptacją społeczną. Przejawia się to w pozytywnym postrzeganiu siebie, realizowaniu osobistych celów, nawiązywaniu kontaktów interpersonalnych oraz pozytywnych relacji z członkami rodziny i otoczeniem społecznym. Z kolei w odniesieniu do osób odbywających karę pozbawienia wolności wysoki poziom koherencji wiąże się z lepszym przystosowaniem osobistym głównie w zakresie dążenia do realizacji osobistych zamierzeń oraz słabego natężenia problemów 
psychologicznych. W ich przypadku poziom koherencji nie wpływa na poziom samooceny, podejmowania konstruktywnych relacji pozarodzinnych oraz kontaktów rodzinnych. W grupie ekswięźniów odnotowano natomiast wysokie natężenie składowych poczucia koherencji (zrozumiałości, sensowności i zaradności), które korelują dodatnio z pozytywnym przystosowaniem osobistym oraz z pozytywną adaptacją w zakresie: osiągania osobistych celów, wysokiego poziomu samooceny, niskiego natężenia problemów psychologicznych oraz nawiązywania konstruktywnych relacji interpersonalnych. Natężenie poczucia koherencji nie jest natomiast istotnie powiązane z jakością i charakterem relacji $\mathrm{z}$ członkami rodziny.

Rozpatrując zagadnienie niedostosowania społecznego i przestępczości w perspektywie rozwojowej, należy nawiązać do teorii przywiązania Johna Bowlby'ego [1980, 2007]. Zakłada ona, że osobowość i zachowania człowieka w dorosłości są zależne od jego wczesnych doświadczeń wygenerowanych wzorem przywiązania. Na powiązania między społecznym zachowaniem a doświadczaniem przywiązania wskazują liczne badania. Na przykład wyniki badań Kennetha N. Levy'ego i in. [1998] oraz Rossa A. Thompsona [1999] nad dziećmi pozwalają przypuszczać, że niekorzystne wzory przywiązania są odpowiedzialne za defensywne procesy w relacjach z innymi. Z kolei korzystne, bezpieczne przywiązanie kształtuje sferę emocjonalną na poziomie względnie stabilnym i kreuje zdolność do nawiązywania i utrzymywania relacji z innymi ludźmi oraz rozwój umiejętności społecznych [Rostowski 2003]. Wykazano także, że wzory zachowań rodzicielskich, m.in. akceptacja, odrzucenie, niepewność, bezradność, korelują z poczuciem bezpieczeństwa i niezależności oraz tendencją do unikania lub zaabsorbowania [Hesse 1999]. Z problemami zachowania oraz czynami przestępczymi współwystępuje przywiązanie unikowe [Renken i in. 1989]. Prawdopodobnie jest to zależność wynikająca z faktu, że wczesne doświadczanie braku reakcji opiekuna na potrzebę bliskości uczy dziecko ignorowania własnych odczuć dystresu oraz tego, że nie może ono liczyć na zaufanie innych osób. Unikowy wzór przywiązania odgrywa zatem rolę wzmacniającą odporność dziecka na przyszłe zaburzenia. Zwiększa także prawdopodobieństwo nadużywania alkoholu przez dziecko w dorosłości [m.in. Nazarko, Bielska 2012].

Badanie ukierunkowane na określenie związku między przywiązaniem a zachowaniami agresywnymi przeprowadziły Marzanna Farnicka i Iwona Grzegorzewska [2016]. Wyniki tego badania wskazują na związek poziomu agresywności z wymiarami przywiązania. Ponadto na genezę postawy wrogiej i odrzucającej mogą wskazywać rozpoznane związki wymiaru zaufania do matki z wszystkimi wymiarami agresywności oraz złości z alienacją zarówno do matki, jak i ojca. Generalnie rzecz ujmując, relacja rodzic-dziecko jest czynnikiem ryzyka i może być źródłem psychopatologii, której etiologia jest złożona i bardziej kompleksowa [Plopa 2007].

Badania przeprowadzone przez Hagana, Simpsona, Gillisa [1987] oraz Hagana [1989] wykazały, że rozkład władzy w rodzinie oparty na pozycji, jaką 
zajmują rodzice w domu i poza nim, warunkuje interpretacje i odtwarzanie przez dzieci społecznych ról płci (aktywność obejmująca troskę rodziców o ochronę i socjalizację do ról pełnionych przez dzieci w życiu dorosłym) oraz kształtuje społeczny rozkład przestępczości.

Wieloaspektowe badania nad rodzinami w kryzysie wieloproblemowym (w tym z problemem postpenitencjarnym) wskazują na słabą kondycję dysfunkcyjnych, wieloproblemowych systemów rodzinnych [Nowak 2011]. Cechuje je bowiem niski poziom przystosowania do zmian zewnętrznych wynikających z przeobrażeń otoczenia społecznego oraz niski poziom przystosowania do zmian wewnętrznych będących efektem naturalnego rozwoju rodziny. Członkowie rodzin dotkniętych kryzysem złożonym mają silne poczucie trudności rozwojowych i upośledzenia funkcjonalnego oraz wykazują tendencję do wchodzenia w patogenne role rodzinne. Osoby strategiczne dla funkcjonowania rodziny posiadają znaczne deficyty w zakresie artykułowania potrzeb, umiejętności konstruktywnego radzenia sobie z problemami oraz poszukiwania pomocy i wsparcia społecznego. W większości przypadków posiadają także niski poziom kompetencji społecznych, czego przejawem są między innymi głębokie deficyty umiejętności radzenia sobie w sytuacjach wymagających sprawnego poruszania się w szerszych układach społecznych oraz nawiązywania interakcji sprzyjających radzeniu sobie z problemami w sposób akceptowany społecznie. Tego typu systemy rodzinne cechują się niskim poziomem adaptacyjności i wzajemnego zrozumienia oraz wysokim poziomem dezintegracji.

Członkowie rodzin wieloproblemowych stosują najczęściej sztywne strategie zaradcze, które blokują im wyjście z kryzysu i umacniają go. Powoduje to utratę poczucia orientacji w społecznym funkcjonowaniu, a w konsekwencji poważne zagrożenie marginalizacją i wykluczeniem społecznym. Jak wskazują wyniki cytowanego badania, praźródła problemów wywołujących kryzys wieloproblemowy tkwią w bezrobociu, biedzie i uzależnieniach członków rodzin od alkoholu i innych środków psychoaktywnych. Złożona i ze wszech miar niekorzystna jest także psychospołeczna sytuacja dzieci wychowujących się w tego typu rodzinach. Są one narażone na doświadczanie traumatycznych sytuacji i stanów zagrażających ich prawidłowemu rozwojowi. Prezentowane przez rodziców wzorce socjalizacyjne są źródłem przejawianych przez nie w dorosłości nieprawidłowych postaw społecznych, deficytów komunikacyjnych i trudności w radzeniu sobie z problemami.

Retrospektywny opis rodzin pochodzenia naszkicowany przez badanych recydywistów penitencjarnych $\mathrm{w}$ ramach prezentowanych badań potwierdza tendencję do obrony obrazu osób znaczących [Bradshaw 1994], determinowaną cechami rozwojowymi oraz warunkowaną społecznie i kulturowo. Poddając się tej tendencji, w wielu przypadkach osoby badane ,podrasowywały” opis swoich wspomnień z dzieciństwa i wczesnej młodości, co prowadziło do niespójności w przebiegu narracji i znacznie ograniczało uzyskanie realistycznego obrazu ich środowisk rodzinnych. 
Mieszkaliśmy w małym mieście. Moja rodzina była duża - rodzice, ja, siostra i dwóch braci. Byto biednie... Tata pracowat dorywczo, troche pit, trochę nas bił, jak to ojciec..., a mama to za uszy targała tak, że do dziś mam jakiś uraz i nie cierpię, gdy mnie ktoś dotyka w to miejsce. Rodzice korzystali też z zasitków, bo mama nie pracowała, $w$ domu z nami była [...] Tak ogólnie dobrze było, na nic nie narzekatem, niczego mi nie brakowało. Jeździliśmy nad morze, nad Bug najczęściej, a potem jak byliśmy starsi, chodziliśmy razem do knajpy, pogadać trochę. $W$ domu byty różne urodziny i inne balangi, jak to $w$ domu, nie? [...] Na kurs języka angielskiego chodzitem, na kurs tańca też, w szkole graliśmy w pitke i zbieraliśmy się, no tak, bytem jakimś członkiem grupy. Spotykaliśmy się w amfiteatrze, kurka, no na mieście, na boisku, u kogoś pod domem [...] Jak zawiniliśmy, to raczej było tlumaczenie ze strony rodziców i nigdy nie zostatem uderzony przez ojca czy matkę. Dzieciństwo moje radosne byto caly czas. Zadowolony jestem z dzieciństwa. Lepiej się cieszyć, niż smucić, nie? [K.M. — 28 lat, kawaler, mieszkaniec małego miasta, wykształcenie średnie, recydywista jednokrotny, wyroki skazujące za jazdę samochodem pod wpływem alkoholu]

\section{Wspomnienia z dzieciństwa...}

Mając na uwadze wielość kryteriów, na podstawie których budowane są klasyfikacje i typologie rodzin, w prezentowanym badaniu skoncentrowano się na typologii rodzin, bazującej na kryterium struktury rodziny. W polskiej literaturze naukowej przyjmuje się założenie, że rodzina o pełnej strukturze (oparta na związku małżeńskim, złożona z rodziców i dzieci) stanowi pożądany wzorzec społeczny. Przeciwieństwem rodziny pełnej jest rodzina niepełna, w której funkcjonuje tylko jeden rodzic zajmujący się prowadzeniem gospodarstwa domowego oraz opieką i wychowaniem dzieci [Tyszkowa 1974]. Rodziny niepełne naznaczone są niekompletnością struktury i wyróżniane na podstawie zaistniałych przyczyn. Są wśród nich rodziny:

- zdekompletowane - rozbite wskutek rozwodu/separacji rodziców lub śmierci jednego z nich oraz tworzone przez niezamężne matki z dzieckiem;

- rodziny rozbite — opuszczenie przez matkę lub ojca;

- rodziny niepełne czasowo wskutek migracji zarobkowej jednego z rodziców, pobytu w zakładzie karnym czy długotrwałego leczenia szpitalnego.

Odrębnym typem rodziny jest rodzina zrekonstruowana, złożona z matki/ ojca, macochy/ojczyma lub adoptowanego dziecka. Inne kryteria jej wyodrębnienia odnoszą się do powodu dezintegracji poprzedniej rodziny (rozwód/śmierć współmałżonka); posiadania dzieci (dzieci jednego małżonka lub obydwojga); sytuacji prawnej oraz trudności pojawiających się w rodzinie. W odniesieniu do dwu ostatnich kryteriów M. Robinson [za: Kwak 2000] wyróżniła następujące podtypy rodzin zrekonstruowanych: 
- rodzina usankcjonowana prawnie przez zawarcie związku małżeńskiego przez osobę wychowującą dziecko z osobą niebędącą jej naturalnym rodzicem;

- rodzina ożywiona wskutek zawarcia nowego związku małżeńskiego przez biologicznego rodzica dziecka po śmierci naturalnego rodzica dziecka;

- ponownie założona, poprzedzona rozwodem naturalnych rodziców dziecka;

- złożona rodzina zrekonstruowana, w której obydwoje partnerzy mają dzieci z poprzednich związków.

W oglądzie zewnętrznym rodziny zrekonstruowane przypominają rodziny pełne, ale ich specyfika polega na tym, że stanowią miks członków należących do naturalnego środowiska rodzinnego oraz członka lub członków dołączonych, nowych, niespokrewnionych biologicznie [Kozdrowicz, Pilch 1984; Czapiga 1994; Dyczewski 1994; Han-Ilgiewicz 1995; Szymanowska 2000; Kwak 2000; Lewandowska-Walter 2006; Walęcka-Matyja 2009].

Niezależnie od typu rodziny pochodzenia, w narracjach badanych recydywistów pojawiał się często motyw babci lub dziadka jako osób wspierających, mądrych i dobrych, ale też interesujących, zabawnych i dających im wiele swobody. Jednak dość często, już z perspektywy osoby dorosłej, oceniali oni niezbyt dobrze ten liberalny sposób wychowania. Wiele wypowiedzi osób badanych odnosiło się także do zjawiska przejmowania przez babcię lub dziadka roli matki, ojca lub obojga rodziców. Tylko nieliczni recydywiści opisywali swoje rodziny pochodzenia jako wielopokoleniowe, w rozumieniu tworzenia wspólnoty mieszkaniowej i prowadzenia wspólnego gospodarstwa domowego. Najczęściej pojawiały się wypowiedzi sugerujące oddzielne miejsca zamieszkania rodziców i dziadków. Symptomatyczne jest to, że niemal wszystkie odniesienia i wspomnienia osób badanych z wydarzeń, relacji i kontaktów z babcią lub dziadkiem, pełne były pozytywnych emocji - miłości, czułości i wdzięczności.

Pochodzę z matej robotniczej rodziny. W domu byto nas czworo: ojciec, matka, ja i młodsza siostra. Najczęściej razem spędzaliśmy czas, wyjeżdżając do rodziny za miasto, na święta, urlopy $i$ wakacje. Często razem z ojcem lub babcia wybieraliśmy się zwiedzać Warszawę lub po prostu chodziliśmy do kina [...] Najbardziej kochatem wiecznie zapracowana matke, ale to babcie i dziadkowie rozwijali we mnie wszelkie zainteresowania i ciekawość świata. Dzięki nim wcześniej niż rówieśnicy nauczytem się liczyć, czytać i pisać, a będąc ośmiolatkiem, cieszytem się duża samodzielnościa w poruszaniu po mieście. W wieku dziewięciu lat zaczątem uczęszczać do Pałacu Młodzieży [...] Bratem udziat w organizacji corocznych imprez okolicznościowych, festynów oraz innych wydarzeń pod egida PKiN, a za uzyskane w ten sposób ,granty” wyjeżdżatem na letnie obozy młodzieżowe. Należatem do ZHP, byłem zuchem i chwilkę harcerzem. A wszystko to zawdzięczam dziadkom. [M.L. — 45 lat, żonaty, mieszkaniec dużego miasta, wykształcenie średnie, recydywista jednokrotny — wyroki skazujące za kradzieże] 
Moja rodzina była duża, wielopokoleniowa. Byto nas ośmioro - siedmioro rodzeństwa plus ja, ojciec, matka, babcia i ciotka, czyli ojca siostra. Wszyscy dorośli byli zajęci praca, a dzieci bujały się po dworze (śmiech). Najbardziej kochatem babcię. Taka najlepsza była, można powiedzieć, że lepsza niż matka. Po prostu taki charakter miała, już jej nie ma, bo już zmarta. To byta taka osoba, jak to się mówi, która od siebie odjęta, a innym dała. Dobry czlowiek, który oddziaływat pozytywna energia, chciato się przy takiej osobie być i z nia rozmawiać. [A.Ł. - 36 lat, żonaty, mieszkaniec wsi, wykształcenie średnie, dwukrotny recydywista, wyroki skazujące za pobicia]

Zdecydowana większość badanych recydywistów wychowywała się w rodzinach o pełnej strukturze. Recydywiści jednokrotni oraz osadzeni w zakładzie typu półotwartego częściej wywodzili się z rodzin pełnych w porównaniu z recydywistami wielokrotnymi oraz osadzonymi w zakładzie typu zamkniętego. Osoby wychowujące się na wsi, najczęściej w rodzinach pełnych i wielopokoleniowych, z rozrzewnieniem wspominały swoje dzieciństwo. Kreowały obraz silnych więzi z rodzicami, szczególnie z ojcami, które pomimo ich postępowania i kolejnych pobytów w więzieniu, nie zostały zerwane, a wręcz przeciwnie relacje z nimi są nadal dobre i wspierające.

$W$ domu byto sześć osób, rodzice, troje dzieci i dziadkowie. Ja rzadko spędzatem czas $w$ domu z rodzina, bo dużo pomagatem $w$ gospodarstwie. Najbardziej kochatem tatę, bo jesteśmy strasznie do siebie podobni. Moje dzieciństwo byto radosne, uwielbiatem jeździć z tata samochodem i ciagnikiem, często udawatem, że chory jestem, żeby do szkoty nie iść, tylko $z$ nim jechać. $W$ domu nie byto przemocy, jak to nieraz $w$ rodzinach bywa. Rodzice mieli do mnie zaufanie i maja nadal. Tylko jak się rozwiodtem, to trochę się relacje zmienity. Zawsze się ich stuchatem i pomagatem. Bytem najstarszy i miałem najwięcej obowiązków. $Z$ rodzicami cały czas mam kontakt. Tata byt raz u mnie, ale mamie powiedziatem, żeby nie przyjeżdżała, bo to nie jest odpowiednie miejsce. $Z$ moim rodzeństwem nie jestem zżyty... W podstawówce należatem do paczki sasiedzkiej. Na jabtka do sadu się chodziło, albo graliśmy w piłkę. Na wagary parę razy poszedtem, ale musiałem potem nadrabiać zaległości. Czasem na wiosnę ze dwa razy poszedtem. Chodziliśmy do parku pobliskiego, albo do sadu - chowaliśmy się po krzakach, żeby nas nie znaleźli. Rodzice nie zabraniali mi się, $z$ nimi kolegować, ale ja to wole sam być niż w grupie. Matury nie robiłem, bo nie miałem czasu, kawalerka w głowie była. Chodzitem zaocznie do liceum. [K.K. - 32 lata, mieszkaniec wsi, wykształcenie średnie, dwukrotny recydywista, wyroki skazujące za kradzieże]

We wspomnieniach osób badanych pojawia się także obraz rodziny pełnej, w której rodzice obłożeni pracą, zmęczeni i sfrustrowani, niewiele czasu poświęcali swoim dzieciom, choć je kochali i na co dzień wspierali. Ten wzorzec 
relacyjny przenoszony jest przez dzieci w dorosłość, zwłaszcza w sytuacji, gdy wraz z upływem czasu struktura rodziny pochodzenia w sposób naturalny ubożeje i z jej składu osobowego pozostaje już tylko rodzeństwo.

Moja rodzina nie byta duża, bytem tylko ja i młodsza o 5 lat siostra, no i oczywiście rodzice. Rzadko spędzaliśmy czas ze soba, bo rodzice w większości pracowali, więc jak wracali do domu, to byli już zmęczeni. Wydaje mi się, że moje dzieciństwo byto raczej szczęśliwe, ale wiadomo, czasem bywaty gorsze dni czasem lepsze, ale ogólnie nie narzekam. Jak byłem mtody, to stuchatem się rodziców, nie miatem wtedy jako takiej sity przebicia. Jak miałem problem, to rodzice starali sie mi pomóc, jak tylko mogli. No jak już bytem starszy, to trochę się zmienito, stałem się bardziej buntowniczy, bardziej się stawiatem, nie stuchatem sie już tak mamy, a ona nie nalegała. Ojciec się denerwowat, jak coś odpyskiwatem mamie, ale jako takich któtni to raczej nie byto. Oni kochali nas, ciężko pracowali, aby jakoś nam się żyło. Z czasem było gorzej, bo z wiekiem ojciec zacząt więcej pić, więc i brakowato pieniędzy, dlatego potem pomagatem im finansowo. Czułem, że jestem też im to, w jakiś sposób winny. Rodzice wychowywali nas raczej swobodnie, ale mieliśmy jakieś reguty czy tam zasady, których musieliśmy się trzymać, aczkolwiek nie było to jakieś sztywne. Teraz z siostra mam caty czas dobry kontakt. Wspieramy się wzajemnie, szczególnie po tym, jak pięć lat temu zmarli nasi rodzice. [K.L. - 43 lata, mieszkaniec miasta średniej wielkości, wykształcenie zawodowe, trzykrotny recydywista, wyroki skazujące za kradzieże i kradzież z włamaniem]

Pomimo tego, że wyniki badania wskazują na dysfunkcjonalny charakter rodzin z problemem penitencjarnym, wiele opisów życia rodzinnego sporządzonych przez badanych recydywistów wskazuje na to, że pomimo problemów, z którymi borykały się ich rodziny, rodzice starali się ich wychowywać, zgodnie z wartościami dającymi im podstawy do wykreowania dobrej, konstruktywnej dorosłości. W dni wolne od pracy organizowali wspólny wypoczynek, starając się zaspokoić dziecięce potrzeby (bezpieczeństwa, miłości czy przynależności), umacniać więzi czy też poprawiać relacje wewnątrzrodzinne. Chronili je przed destruktywnym wpływem rówieśników, kochali i starali się zapewnić im dobrą przyszłość.

Moja rodzina byla niewielka - ja moja siostra i rodzice. Rodzice pracowali, ale kiedy mieli wolne, to ten czas spędzali z nami. To wygladało tak, że ja często z moim tata jeździłem na grzyby, które mój tata uwielbiat, czessto gratem z nim w pitkę na boisku lub pod blokiem. Zdecydowanie aktywnie spędzaliśmy razem czas $w$ miarę naszych możliwości. Tata też zapisywat mnie na różnego rodzaju sporty wyczynowe $i$ starat się mnie jakoś w tym wszystkim wspierać, żebym się nie nudzit. Staratem się stuchać rodziców $i$ z reguły było tak, że dobrze starali się nami kierować $i$ wszystko byto $w$ porządku, w miare normalnie. Rodzice 
starali się rozwijać nasze pasje, ale przede wszystkim chcieli, byśmy byli wyksztatceni i na to kladli nacisk, a dopiero później byt czas na nasze przyjemności. Ogólnie, to na pierwszym miejscu była nauka, szkoła $i$ nasze obowiazki. Jak się źle z siostra zachowywaliśmy, to traciliśmy nasze przywileje czy wyjścia ze znajomymi, a jak byto w porzadku, to zdarzaty sie jakieś małe nagrody, ale to byty drobnostki. Rodzice starali się, wpoić nam dobre wartości, za co im bardzo dziękuję. Nie uciekali się do fizycznej przemocy. Wiadomo, zdarzały się i trudne chwile, jakieś awantury, jakiś klaps czy tego typu sprawy, nie jakieś znęcanie się czy wyżywanie na dzieciach. Niestety oboje rodzice już nie żyją. Mam mtodsza siostrę o 3 lata ode mnie, czyli ma 37 lat. Ma swoja rodzinę, męża $i$ dwoje dzieci. Mam z nia staty kontakt telefoniczny. Nasze stosunki teraz nie sa rewelacyjne, ale też nie sa złe. Za czasów dzieciństwa były lepsze. Każde z nas ma swoje życie i poszło $w$ swoja stronę. Na wolności spotykaliśmy się czasami u niej na rodzinnego grilla czy urodziny. Wydaje mi się, że siostra miała mi za złe, że zszedtem na zła drogę. Widziała, jak nasza mama bardzo to przeżyla i zszarpała sobie na tym nerwy. Rodzice uważali, że miatem potencjat, że jestem dobrym człowiekiem, ale mimo to wyczuwatem ich wewnętrzne pretensje do mnie o ten stan rzeczy [...] $Z$ dzieciństwa pamiętam, że jak miatem chyba z 15 lat, to odwiedziłem $z$ moimi rodzicami dom dziecka, w którym wychowywat się mój tata, ponieważ jego rodzice, czyli moi dziadkowie, zginęli w czasie wojny. Tam byt taki ksiadz, który miat przeszło 90 lat i bardzo dobrze mojego tate pamiętat. Spędziliśmy tam chyba z trzy dni, a tata mi pokazywat cała placówkę, okolice, tam gdzie wraz z rodzeństwem przebywali. No tak powiem, troszeczke mnie to ruszyło. Widziałem, tata pare razy miat tzy w oczach. Wzruszyt się bardzo na wspomnienie tego miejsca $i$ tych czasów. Jak mówit, byly takie momenty, że inne dzieci szly do nowych rodzin, a mój tata zostawat. Nikt nie byt $w$ stanie wziać pięciorga dzieci, aż wreszcie musieli ich rozdzielić [...]. Rodzice nie wszystkich moich kolegów tolerowali, byta część kolegów, którzy dobrze ze mną żyli i moi rodzice na przyktad znali się z ich rodzicami, a była też część, z która nie pozwalali mi się spotykać. Można powiedzieć, że byty to dzieciaki z takich rodzin patologicznych, gdzie byt alkoholizm [...] W szkole dobrze się uczyłem, miatem dobre oceny, nawet lepsze od mojej siostry. Mimo tego, że moja siostra była prymusem, to potrafitem być czasem lepszy od niej, z czego moja mama byla dumna, tym bardziej, że pracowała $w$ naszej szkole. Byta kierowniczka na kuchni, ale ze względu na to, że miatem część kolegów, którzy mieli na mnie zły wptyw, trochę sobie u niej przechlapatem. Miatem bardzo złe oceny z zachowania, mimo że bardzo dobrze się uczytem. Wynikato to z tego, że na przerwach wstepowat we mnie diabet. [J.K. - 40 lat, mieszkaniec dużego miasta, wykształcenie zawodowe, czterokrotny recydywista, wyroki skazujące za pobicia i rozboje] 
Moja rodzina jest spora, tam gdzie mieszkam. Mam siostrę rodzona oraz siostre i brata przyrodniego ze strony ojca. Tak naprawdę to ja się wychowywatem sam, bo moja siostra już ponad 25 lat jest za granica, ale mam z nia bardzo dobry kontakt. Każdy raczej spędzat czas oddzielnie, no chyba że gdzieś się czasem wyjeżdzało za granice, a tak to nic szczególnego się nie działo. Ojciec całe życie pracowat, a mama jest rencistka i nigdzie nie pracuje. Starała się czasem zorganizować nam czas, jakieś wyjścia na baseny czy coś, ale później wszystko się skończyło, bo byłem starszy i pojawili się koledzy. No i skończyly się wyjazdy i czas spędzany z rodzina - rodzicami. Myślę, że najbardziej zwiazany byłem z matka, bo ojca caty czas nie byto, bo pracowat. Czasami z ojcem - jak jeszcze miat czas — jeździliśmy na ryby. To mi się bardzo podobato, ale teraz nie mam hobby. Wcześniej to byty jeszcze jakieś ćwiczenia, siłownia, no ale teraz jakoś zanikła motywacja. Tak powiem. Moje dzieciństwo byto raczej szczęśliwe, nie moge powiedzieć, że byto jakieś patologiczne, że była tam przemoc czy coś takiego. Więc raczej szczęśliwe byto. Raczej tak, liczyłem się ze zdaniem swoich rodziców, nie rozgraniczatem ich jakoś. Ogólnie dobry miałem do nich stosunek, choć ja byłem dla nich niezbyt dobry i mi to ciagle powtarzaja, no i może przez to tu jestem, że się ich nie stuchatem. Po prostu, oni chcieli dla mnie jak najlepiej, a że ja poszedtem $w$ taka stronę nie $w$ inna, no to już moja wina. Kary raczej też nie byty stosowane, raczej byto, rób, co chcesz. Jak mieli jakiś pomyst na kare, to ja po prostu wychodziłem i nie chciatem tego stuchać. Może próbowali, no ale ja ich nie stuchatem. Co do moich znajomych to stosunek rodziców do nich byt różny — od jednych mnie odciagali, o innych mówili koleguj się z nimi, bo sq w porzadku. No, ale ja i tak robitem to, co chciałem. $Z$ dzieciństwa to takim wspomnieniem, które utkwiło mi w pamięci, to byt nowotwór matki. Miatem wtedy 13 lat i odbito się to na mnie mocno, to pamiętam jak dzisiaj. No, ale Bogu dzięki nie było to nic poważnego, nie było to na szczesście złośliwe. Ale bytem matym dzieckiem i pamiętam, jak matka mnie wzięta na kolana i zaczęła o tym mówić, no i to pamiętam do dziś. [D.Ł. - 29 lat, duże miasto, wykształcenie wyższe, recydywista jednokrotny, wyroki skazujące za rozbój i posiadanie narkotyków (uprawa marihuany)]

W rodzinie o strukturze zrekonstruowanej wychowywała się niemal $1 / 3$ badanych recydywistów, a jej skład uzupełniał najczęściej ojczym. Badani recydywiści w większości przypadków opisywali swoje relacje z ojczymem jako złe, drażniące i prowokujące ich do nieposłuszeństwa i szukania wsparcia w grupie rówieśniczej. Inni podkreślali ich zły wpływ na matkę, szukanie zwady i stosowanie autorytarnych metod wychowania dzieci. Wspominali częste awantury domowe, nadużywanie alkoholu, zachowania przemocowe. Niemal wszyscy obwiniali ojczymów za swój los, za to kim się stali. 
Mam brata i siostre starsza po innym ojcu. Ja jestem po innym ojcu, ale przyjątem nazwisko po swojej mamie. Gdy moi rodzice się rozwiedli i zacząt mieszkać z nami nowy partner mamy, to rozpętało się piekło. Nie dogadywatem się z ojczymem, który lat mnie pasem, gdzie popadto, bo nie chciałem robić tego, co mi kazat. I matkę też chciat przekabacić na swoja stronę, ale się nie dawata. No bo jakie on prawo do tego miat, by mna rzadzić? Dla mnie to przecież obcy człowiek byt. W końcu zacząłem uciekać z domu, ale tak tylko na dwa - trzy dni. Potem to zawsze odpokutowatem, ale przez ten czas miatem trochę spokoju i robitem, co chciatem [...] W podstawówce gratem w nogę, bo w moim mieście taka była szkótka pitkarska, ale że zaczątem późno, to ta droga, jak to się mówi, skończyła się. Zamiast iść caly czas tym torem, to wdatem się $w$ takie towarzystwo, w jakie się wdatem i poszedtem w inna stronę. Nie chciało mi się po prostu chodzić do szkoty. Teraz już bym do niej chodzit. Wie Pani, teraz to bym się mógt uczyć. I żatuję, że wcześniej się nie uczytem. Jakoś im bardziej jestem starszy, tym chętniej bym poszedt do szkoty. No i kumple swoje robili. Nauczytem się od nich wiele - pić, kraść, ćpać $i$ w gębę lać (śmiech) [K.K. - lat 40, rozwiedziony, mieszkaniec małego miasta, wykształcenie zawodowe, recydywista jednokrotny, wyroki skazujące za posiadanie narkotyków oraz kradzież auta]

Niektórzy badani recydywiści wspominali jednak przybranych ojców jako osoby wspomagające rodzinę, starające się zaprzyjaźnić z dziećmi swojej partnerki, opiekujące się nimi i troszczące się o ich rozwój.

Moja rodzina byta duża, bo mam 4 siostry $i 3$ braci. Ale ona byta $w$ rozsypce, bo siostry wychowywane byty przez kogo innego, bracia tak samo. Zostało nas dwu braci i jedna siostra i mama nas wychowywała, ale ogólnie kontakt byt utrzymywany. No wiadomo przede wszystkim mama, co do ojca to nie wiem, nie znatem go. Była tam później rozmowa jak już dorośliśmy, że ojciec zginąt i nie mieliśmy okazji, aby go poznać. Później ojczym zastapit mi mojego ojca, no ale tak samo potem zmart. Dobrze się raczej dogadywaliśmy, no i byto ciężko po jego śmierci... [P.S. — 29 lat, średnie miasto, wykształcenie zawodowe, recydywista jednokrotny, wyroki skazujące za rozprowadzanie narkotyków]

Matka mnie sama wychowywata. $Z$ ojcem sie dawno temu rozwiodta i od tamtego czasu nie utrzymuję z nim kontaktu. Najczęściej ogladaliśmy telewizję. Matka nie miata dla mnie zbyt wiele czasu, bo ciagle pracowała. Nie byto wiele pieniędzy $w$ domu, więc poza jazda na rowerze i pitka nożna nie miałem żadnego hobby. Moje dzieciństwo byto biedne, ale szczęśliwe. Zapamiętałem najbardziej ojczyma, którego bardzo kochałem, ale zmart gdy miatem 13 lat. Byt dla mnie ideałem, traktowat mnie bardzo dobrze, okazywat wobec mnie uczucia jak prawdziwy ojciec. Kolegów miałem sporo. Zawsze byłem osoba towarzyska. Chodzitem na wagary, bo robito się w szkole nudno i fajniej byto 
połazić po mieście. Głównie spotykaliśmy się na podwórku, graliśmy w piłkę i bawiliśmy się w różne zabawy. [B.C. - 37 lat, żonaty, mieszkaniec dużego miasta, wykształcenie zawodowe, recydywista czterokrotny, wyroki skazujące za uprowadzenia, oszustwo, kradzieże oraz pobicia]

$Z$ mama się wychowatem i z takim można powiedzieć przybranym ojcem. On z nami nie mieszkat, ale pomagat mamie we wszystkim. Relacje między nami byty dobre, liczylem się z jego zdaniem w jakiś poważniejszych kwestiach, ale trochę bytem taki przekorny - mówitem jedno, a robiłem drugie. Mój biologiczny ojciec żyt jeszcze wtedy, ale nie mieszkałem z nim i bardzo rzadko się widywaliśmy. [B.C. - 33 lata, małe miasto, wykształcenie wyższe, recydywista jednokrotny, wyroki skazujące za oszustwa]

We wspomnieniach wielu osób badanych pojawienie się ojczyma wiązało się z poprawą atmosfery wewnątrzrodzinnej, z wyciszeniem emocji, ale prowadziło do zaburzeń w relacjach z matką i osłabienia wpływu wychowawczego. Często wiązało się to z przyjęciem przez dorosłych liberalnego stylu wychowania lub owocowało niewydolnością wychowawczą.

Było nas czworo. Ojczym, matka, ja i brat. Matka rozeszła się z moim ojcem, gdy bytem mały. W późniejszym okresie (13-18 lat) bytem $w$ zakładzie wychowawczym, więc widywaliśmy się rzadko. Jak matka jeszcze była z moim ojcem, to pamiętam, jak on znęcat się nad nia.. Matka rozwiodła się z ojcem i zwiazała z ojczymem, jak miatem 6 lat. I było wtedy troche spokojniej. Jak bytem maty, to nie stuchatem mamy, bo wadzit mi ten ojczym i bytem zły na niq. Nie wychodziło im obojgu wychowanie dzieci, nie stosowali ani kar, ani nagród. Puszczali mnie wolno, to znaczy robitem, co chciałem. Najwięcej czasu poświęcała mi babcia, starała się mnie jakoś wychować. Najmilej wspominam wyjazdy do niej i ciotki na wakacje. One mieszkaty na wsi i było tam fajnie. Przez lata nie utrzymywatem kontaktu z biologicznym ojcem. Wiem, że parę razy siedziat i później próbowat sobie ułożyć życie, ale nie wychodziło mu, no i 5 lat temu umart. Mnie to teraz tylko matka wspiera, ale z bratem też mam dobry kontakt. [A.D. - 42 lata, mieszkaniec średniej wielkości miasta, wykształcenie podstawowe, recydywista siedmiokrotny, wyroki skazujące za kradzieże]

Wśród badanych recydywistów byli i tacy, którzy wychowywali się w rodzinie zrekonstruowanej, ale prowadzonej przez ojca. Najczęściej ciężar wychowania w takich rodzinach spoczywał na dziadkach, którzy przejmowali funkcję wychowawczą. Było to podyktowane najczęściej permanentną nieobecnością ojca usiłującego utrzymać rodzinę i zaabsorbowanego pracą oraz obojętnością macochy wobec powierzonych jej dzieci i ich emocjonalnych potrzeb.

Ojciec mnie wychowat i macocha. Mama... ja nie znam mamy. Miałem 7 miesięcy, jak mama uciekta za granice i rozwiodta się z ojcem. Było 
nas trzech braci - ten o 10 lat starszy ode mnie zostat z nami, a drugi, starszy o 4 lata, wyjechat z matka, ale o niej nie chce mi się rozmawiać. Mój tata pracowat, a ja głównie u babci siedziałem, a w zasadzie to u niej mieszkatem. Potem doszła do nas macocha - wredna, zimna kobieta. Dzieciakiem byłem, matki nie pamiętałem i bardzo chciatem, by mnie przytuliła czasem, po głowie pogłaskała, ale ona.. ech! nie warto nawet wspominać tej baby... Babcia na wszystko mi pozwalała. To byta komuna, tata za granice wyjeżdzat. Było troche inaczej. Pałętatem się gdzieś po podwórkach. Dzieciak bytem, ale sobie dawatem radę. Myślę, że wszystko bytoby dobrze, tylko że miatem zbyt dużo swobody, zaczątem się zadawać z osobami, z którymi nie trzeba i jako dziesięcioletni dzieciak poszedtem do jednego zaktadu poprawczego, potem do drugiego i tak to... Jak to dzieciak, bujatem się po prostu, wszedtem $w$ złe kręgi. Raczej nikogo nie stuchałem. Dopiero później zmądrzatem, że warto się byto ojca stuchać. Wcześniej to taki buntownik raczej bytem. Zawsze najmadrzejszy i bokiem mi to wyszło..., wliczając te poprawcza$k i$, to z matymi przerwami siedze juz 17 lat w więzieniu. [D.R. - 37 lat, mieszkaniec dużego miasta, wykształcenie podstawowe, recydywista trzykrotny, wyroki skazujące za kradzieże]

W rodzinach o niepełnej strukturze funkcjonowała ponad $1 / 3$ osób badanych. Najczęstszą przyczyną niepełności rodziny był rozwód rodziców. Zdarzały się także przypadki śmierci jednego z rodziców czy wyjazd jednego z nich za granicę na stałe (najczęściej ojca) i zerwanie kontaktu z rodziną. Badani recydywiści postrzegali swoje matki jako osoby silne, zaradne i wspierające ich w różnych aktywnościach. $\mathrm{Z}$ ich narracji wyłaniał się także obraz matki zapracowanej, zmęczonej, często bezradnej.

Moja mama już nie żyje, tata też. Miatem brata przyrodniego. $Z$ mama tylko mieszkatem, ale co tydzień widziatem się z bratem, bo on też ze mna nie mieszkat, tylko mieszkał z babcia, no i wiadomo, jakieś święta, wakacje. Mama pracowała i późno do domu przychodziła. Była silna, dawata sobie radę, ale często serce krajało się na jej widok, bo byta zmęczona i obolata. Pracowata w masarni na dwie zmiany i sit jej caty czas ubywało... [B.C. - 33 lata, małe miasto, wykształcenie wyższe, recydywista jednokrotny, wyroki skazujące za oszustwa]

Liczytem się ze zdaniem matki i szanowatem je. Sama nas wychowywata i jak większość matek, tak i moja czasem karała, czasem było dobrze, a czasem źle. Na pewno chciata dla mnie dobrze. Często dostawałam zakaz wychodzenia z domu, jak coś przeskrobałem. Czasem też dostałem pasem. Teraz jej się nie dziwię, bo ciężko jej było zapanować nade mna, bo nie bylem zbyt grzecznym dzieckiem. Z bratem nie utrzymuje żadnych kontaktów, zanim trafitem do więzienia, miałem z nim raczej złe relacje ze względu na rodzinne sprawy. Z siostra mam staty, dobry kontakt, 
glównie telefoniczny. Używki zaczęty się dopiero, gdy po raz pierwszy wyszedtem z więzienia, miałem chyba 19 lat. To była głównie marihuana $i$ różne wariactwa. Przez to jestem piaty raz w zakładzie. Pierwszy raz bytem skazany, jak miatem 17 lat. [B.C. — 37 lat, żonaty, mieszkaniec dużego miasta, wykształcenie zawodowe, recydywista czterokrotny, wyroki skazujące za uprowadzenia, oszustwo, kradzieże oraz pobicia]

Badani recydywiści przyznawali się do błędów młodości, do własnych ułomności i cech charakteru utrudniających życie ich samotnie wychowującym matkom. Dokonując analizy swoich dziecięcych zachowań, podkreślali także swoje dobre strony, odnosząc się do sytuacji społecznych, w trakcie których zostały one ukształtowane i przeniesione w dorosłość.

Kiedyś w głowie byta tylko pitka, a potem trochę taniec hip-hop, troche się tam tańczylo. Zapisałem się do grupy $w$ amfiteatrze $w$ [...], no i tam poznatem paru ludzi, którzy mnie wzięli i wciagnęli do swojej grupy, ale to byla taka chwilowa przygoda, bo półtora roku może. Starałem się liczyć ze zdaniem mamy, naprawdę się staratem, ale zawsze próbowatem i stawiałem na swoim. Mama swoje mówiła, ja robiłem swoje, no ale czasami byto tak, że przystawatem do jej woli. Stosunek mamy do mnie to catkiem w porzadku, naprawde, próbowała mi thumaczyć, prowadziła mnie, ale upieratem się, bytem uparty i nie wiem, myślę, że btędem byto to, że jej nie stuchatem. Postanowitem w wieku 15 lat rzucić szkołe, bo mama nas sama wychowywata, więc trzeba byto jakoś pomóc. Poszedtem do pracy, zaczątem pracować, no i szkoła poszła boczkiem. Mama była stanowcza, ale jak wspominatem, stawiatem na swoim. Byty nerwy, ale ja bytem uparty. Kontakt $z$ rodzeństwem mam bardzo dobry nawet teraz, nawet może jest lepszy, bo 8 lat temu poznatem siostrę, tę wtaśnie 4 siostrę, tak jakby zblizyliśmy się, połaczyliśmy się i trzymamy się. Jeśli któreś $z$ nas potrzebuje jakiejś pomocy, to od razu jest jakieś zorganizowanie się i na ile możemy, na tyle pomagamy. Dzieciństwo było raczej dobre, byty czasem gorzkie dni, no ale ogólnie dobrze wspominam. Byłem członkiem grupy młodzieżowej $w$ szkole, $w$ sumie to była liga ochrony środowiska, chodziliśmy, pomagaliśmy różnym instytucjom środowiskowym, przy sprzątaniu. Ja lubię pomagać po prostu, ciagnie mnie do ludzi, żeby im po prostu pomóc, nawet pracowatem w szpitalu na stanowisku salowego. Wiadomo człowiek święty nie byt, no jakoś tak zawsze źle wychodziło. Byta nas grupa 14 osób, to z dawnych lat szkolnych się zebraliśmy, i tak matymi kroczkami, to poprzez Internet się odnaleźliśmy. Teraz to już kontakt się raczej urwat, ale jakby się chciało, to przynajmniej z niektórymi mógtbym nawiąać jakiś kontakt. Do niektórych znajomych mama miata jakieś tam zastrzeżenia, żebym się nie spotykat, bo na pewno jakoś na dobre z nimi nie wyjdę. To raczej byli koledzy z sasiednich podwórek, często się spotykaliśmy, może nawet za często, bo to nie raz głupoty jakieś 
przychodziły do głowy. [P.S. - 29 lat, średnie miasto, wykształcenie zawodowe, recydywista jednokrotny, wyroki skazujące za rozprowadzanie narkotyków]

W toku badań pojawił się interesujący wątek matki samotnej, rezygnującej z formalnego związku dla dobra własnych dzieci — „matki siłaczki”, bez reszty poświęcającej się ich wychowaniu, zastępującej im ojca i dbającej o zapewnienie im dobrego startu życiowego.

Historia mojej rodziny jest taka, że mój tata owdowiat i znalazł sobie partnerkę o 23 lata młodsza - to była moja mama, która mnie urodziła, jak tata miat 60 lat. Z pierwszego matżeństwa tata miat troje dzieci, więc razem byto nas $w$ domu sześcioro. Miałem 11 lat, kiedy tata zmart na raka pluc. Mama została sama i wychowywała mnie już wrodzinie niepetnej. Myśle, że wychowała mnie na dobrego człowieka - nie miatem problemów z uczeniem się, zawsze zdawatem z klasy do klasy, bylem nawet w wielu przypadkach stawiany za wzór. Tata byt dobrym rolnikiem i mężem. Nigdy nie mówit do mamy inaczej jak ,,moja pani”. Mama była przewodniczaca rady gromadzkiej, potem powiatowej. Tata miat duże gospodarstwo, 38 ha rolnych i z tego gospodarstwa żyliśmy dość dobrze. Dopiero po śmierci taty pojawity się problemy finansowe, bo mama sama została na gospodarstwie. Najpierw poszedtem do liceum, ale mama chciała, zebym nauczyt się rolnictwa, więc przepisatem się do szkoły zawodowej [...] Z rodzeństwem przyrodnim spędzaliśmy dużo czasu wolnego poprzez granie na instrumentach - ja gratem na akordeonie. Uczytem się przez sześć lat gry na tym instrumencie i grałem nawet, choć krót$k o, w$ reprezentacyjnej orkiestrze Wojska Polskiego. To byto mite i bardzo chlubne zajęcie, tylko było tam więcej musztry niż grania, ale dobrze byto [...] Pomimo tego, że nie mialem taty, to mama tak się mna zajmowała, jakby on byt. Chciała żebym byt szczęśliwy, chciata zastapić mi ojca, ale potem to ja jej zastępowałem ojca. Mama nie miała poza nim żadnego partnera mimo wielu adoratorów. Bardzo się liczylem ze zdaniem mamy. Jak powiedziała, że mam wrócić na 12, to nie było mowy, żebym nie wrócit [...] Mama już nie żyje, z przyrodniego rodzeństwa też tylko jedna siostra jest na tym świecie. Mam $z$ nia kontakt, ale staby, bo jest już starsza osoba. [A.Ł. - 65 lat, mieszkaniec wsi, wykształcenie niepełne wyższe, recydywista jednokrotny, wyroki skazujące za defraudację i nielegalny pobór energii elektrycznej]

Pochodzę z normalnej, znaczy petnej rodziny, z tym że moi rodzice się rozwiedli. Mam siostre, jest 10 lat starsza ode mnie, ale mamy bardzo dobre relacje. Nasze dzieciństwo byto raczej radosne, większość wspomnień jest dobra. Bytem w grupie osiedlowej i głównie na podwórku robiliśmy różne rzeczy. Wtedy zaczałem też graffiti robić, gdzieś już to się przejawiało i tak mi do dziś zostało (śmiech). Mama namówiła mnie i nawet przez rok studiowatem grafikę i prawdę mówiąc, chciałbym to dokończyć. Jak rodzice byli 
jeszcze razem, to chyba byliśmy z siostra szczęśliwi, ale po rozwodzie byto trochę zamieszania $i$ wszystko się porozjeżdzato. Mama robiła, co mogła, ale nie udato się jej sprawić, bym byt szczęśliwy. No, nie jestem, bo sam sobie jestem winien i przecież rozmawiamy tu, a nie tam (wskazanie ręką na zakratowane okno). Z mama mam nadal dobry kontakt. [R.M. — 29 lat, mieszkaniec dużego miasta, wykształcenie średnie, recydywista dwukrotny, wyroki skazujące za oszustwa, napad i handel narkotykami]

\section{Sytuacja materialna rodzin pochodzenia}

Przeprowadzone przeze mnie badania nad poczuciem lokalizacji kontroli u recydywistów penitencjarnych [Nowak 2017b] wykazały, że rodzice badanych recydywistów posiadali w większości przypadków stałe, etatowe źródło dochodów $(66,3 \%) \mathrm{W}$ tej grupie największe szanse na stałe zatrudnienie mieli rodzice mieszkający w dużych miastach (powyżej 100 tys. mieszkańców — 80,3\%), zaś najmniejsze - mieszkańcy wsi, którzy w ponad połowie przypadków prowadzili własne gospodarstwa rolne. $\mathrm{Z}$ ogólnego obrazu funkcjonowania rodzin pochodzenia osób badanych wynika jednak, że z pomocy społecznej korzystało $64,4 \%$ rodzin. Częściej czyniły to rodziny o pełnej strukturze i wielodzietne niż rodziny o strukturze niepełnej. Ten wynik badania jest zastanawiający z uwagi na fakt, że zdecydowana większość badanych recydywistów przedstawiała sytuację materialną rodziny pochodzenia jako bardzo dobrą, dobrą lub wystarczającą (łącznie 77,2\%). Można przypuszczać, że jest to zarówno efekt próby retrospekcyjnego „wygładzenia” wspomnień o rodzinie, jak i obiektywnego przekazu, zwłaszcza, gdy weźmie się pod uwagę, że zdecydowana większość badanych recydywistów, to osoby w wieku powyżej 30 lat, których rodziny pochodzenia funkcjonowały w państwie opiekuńczym, zapewniającym stałe zatrudnienie wszystkim swoim obywatelom w wieku produkcyjnym. $Z$ drugiej strony domniemywać można, że część rodzin osób badanych nie wykazywała faktycznych dochodów. Teza ta wydaje się prawdopodobna, gdy weźmie się pod uwagę, że rodziny te $\mathrm{w}$ większości przypadków funkcjonowały w okresie transformacji ustrojowej oraz dynamicznych zamian gospodarczo-ekonomicznych, których skutkiem był między innymi exodus emigracyjny.

Jednak bez względu na sytuację materialną, ponad połowa rodziców ogółu badanych recydywistów nie podejmowała dodatkowych wysiłków w celu polepszenia kondycji rodziny. Istotnie częściej bierni w tym zakresie byli rodzice tworzący rodziny pełne niż niepełne. Ta nieporadność w ekonomicznym zabezpieczeniu rodziny determinowana była między innymi takimi czynnikami, jak:

- niski poziom wykształcenia rodziców badanych recydywistów (68,3\% z nich posiadało wykształcenie podstawowe i zawodowe, $25,8 \%$ średnie, a jedynie $5,9 \%$ wyższe);

- trudności w utrzymaniu stałej pracy, wynikające z niskiego poziomu kwalifikacji zawodowych oraz cech charakteru i osobowości, utrudniających 
wykonywanie obowiązków zawodowych (m.in. lenistwo, wygodnictwo, nierzetelność czy brak odpowiedzialności);

- uzależnienia, a zwłaszcza choroba alkoholowa (najczęściej ojca) - czynnik patologizujący życie ponad połowy rodzin pochodzenia badanych recydywistów;

- niski poziom sprawności komunikacyjnych i umiejętności radzenia sobie w sytuacjach trudnych.

Moja rodzina byta duża. Mieszkaliśmy w małej, w dodatku pijackiej wiosce. Sasiednie byty takie same... Byto nas ośmioro, siedmioro rodzeństwa plus ja, ojciec, matka, babcia i ciotka, czyli ojca siostra. Wszyscy byli zajęci praca jakąś, a ja - ulica. Najbardziej kochałem babcię, bo ona lepsza była niż matka. Dzieciństwo miałem smutne, brakowało mi czasu wspólnie spędzanego z rodzina, takiego ogniska domowego, miłości. U nas nigdy nikt nie obchodzit żadnych imienin czy urodzin. Święta to na takiej zimnej stopie. Mój ojciec pit na umór i byt bardzo surowy. Wcześniej miatem do niego pretensje. Tylko w myślach, bo nigdy mu tego nie mówitem, nawet jak do niego przyszedlem się poskarżyć na kogoś, jak ktoś mi krzywdę zrobit, starszy 10 lat ode mnie, bo ja nie datem rady mu nic zrobić. Przyszedtem, poskarżytem się i jeszcze od niego dostatem. Wtedy to byto mi przykro, że ojciec nie chciat mi pomóc, ale teraz jak już jestem dorosty, to cieszę się, że tak mnie wychowat, bo przez to mam taki twardy charakter. Jak już coś postanowię, to się tego trzymam. Ze zdaniem rodziców nigdy się nie liczytem. Bytem najstarszym dzieckiem, więc musiałem się rodzeństwem zajmować albo $w$ gospodarstwie pomagać. Pomagałem im bardziej z przekonania, że trzeba pomóc, bo za bogato nie byto. Ojciec gospodarzyt, ale nie rozwijat się, stat $w$ miejscu, no i ja praktycznie od 15 roku zycia dawałem sam sobie radę. Nigdy nie dostałem nawet złotówki na jakąs dyskotekę. Ubranie to już od dziecka musiatem sam sobie kupić, albo coś ukraść... Zawsze bytem buntownikiem. Z rodzicami za wiele nie rozmawiatem, bo caty czas pracowali, a po pracy gadać, to się im już nie chciato. Jak to na wsi. Nagradzania to żadnego nie byto, ale karanie często byto. Teraz to z ojcem tylko czasami pogadam, bo na catego chla. Taki to mój dom byt, takie pijackie dzieciństwo... [Z.T. — 40 lat, rozwiedziony, mieszkaniec średniego miasta, wykształcenie zawodowe, recydywista dwukrotny - wyroki skazujące za pobicie, kradzieże oraz rozbój z użyciem niebezpiecznego narzędzia]

Mama z ojcem wywodzili się z rodziny robotniczej. Tata byt hydraulikiem i pracowat w państwowej firmie, ciężko fizycznie pracowat. Mama tak samo, sprzedawata w sklepach ze stodyczami czy innymi rzeczami i cate zycie spędziła przy kasie. Mam siostre, jest ode mnie o rok starsza. Jest normalna dziewczyna, wybita się dobrze, dobrze zarabia. Jedyna osoba chyba z rodziny, która normalnie myśli. Co moge powiedzieć jeszcze 
o rodzicach? Ojciec byt wychowany w toku myślenia komunistycznego, czyli praca, praca, alkohol, alkohol, praca, praca..., ech! Mama jest w porządku, z mama jak z koleżanka żyję. Siostra? Siostra też dużo pracuje, nie pije, normalna, spokojna dziewczyna. Dużo mi pomagała w życiu, zatatwiała prace, starała się mnie wyprostować. Ojciec jest teraz caty czas zapity. Ma własne powody, bo przeszedł operację, która nie wyszła i tak topi smutki walkoholu. Wcześniej byt wiecznie zapracowany, ale niepijany jeszcze wtedy. Mama oczywiście poświęcała nam swój czas, ale wiadomo, trzeba byto się zajać domem. Z siostra dużo czasu wolnego spędzatem. Tak do 13 roku życia, bo potem zaczęty się u mnie narkotyki, marihuana, amfetamina, no i już wszystko kręciło się wokół tego. Do domu wracałem tylko na nocleg, a z rana znowu na miasto, coś zarobić i naćpać się. Z ojcem w któtnie popadatem, wiadomo, bo on miat inny tok myślenia niż ja. Ja jestem otwarty na ludzi, na wspótczesne technologie, ogólnie na to co dzieje się na świecie, co mnie też interesuje $w$ danym momencie. Ojciec jest zamknięty i nie nadą̇a za światem. Mnie tez nie ogarniat $i$ byt zawsze strasznie wkurzony, że ja nie spędzam z nim dużo czasu. Chodziło o to, że pracowatem 3 lata przy hydraulice i mu pomagatem. Zamiast zostać z nim po pracy i jemu coś tam dalej pomagać, to ja dzida na miasto i swoje robitem, a jego to denerwowało. W sprzeczki wpadaliśmy, ale tak to ogólnie rodzina moja jest spoko ${ }^{3}$. Było i tak, że jak ojciec zaczą huczeć do matki, to ja już nie pozwalatem. Wychowaliśmy się $w$ dwupokojowym mieszkaniu bez tazienki. W mojej rodzinie po prostu była bieda, ale każdy dawat sobie jakoś radę. Lepiej lub gorzej..., jak ja. [M.J. - 31 lat, kawaler, mieszkaniec wsi, wykształcenie podstawowe, recydywista dwukrotny, wyroki skazujące za usiłowanie zabójstwa, kradzieże i kradzież z włamaniem]

Badania nad sytuacją ekonomiczną rodzin pochodzenia, przeprowadzone z wykorzystaniem strategii ilościowej [Nowak 2017b] wykazały, że aktywność ukierunkowaną na polepszenie bytu rodziny (zazwyczaj była to dodatkowa praca etatowa) podejmowali istotnie częściej rodzice recydywistów osadzonych w zakładach półotwartych, zaś prace dorywcze wykonywali częściej rodzice osób osadzonych w zakładzie zamkniętym. Wyjaśnienie istnienia tej zależności jest jednak trudne i wymaga pogłębienia w toku dalszych eksploracji badawczych. Statystyczna analiza danych badawczych wykazała także istotną zależność pomiędzy występowaniem $\mathrm{w}$ rodzinie pochodzenia problemu uzależnień od środków psychoaktywnych (zwłaszcza alkoholu) a wielkością miejscowości przez nią zamieszkiwanej. Okazało się, że im mniejsza była miejscowość zamieszkania rodzin pochodzenia badanych recydywistów, tym częściej występowała w nich choroba alkoholowa. Wynik te nie koresponduje z wynikami badań innych autorów, które wskazują, że mieszkańcy wsi piją alkohol istotnie

2 „Dzida” — uciekać (określenie żargonowe).

3 „Spoko" - w porządku (określenie żargonowe). 
rzadziej niż mieszkańcy miast [m.in. Kusiak, Szewczyk, Włoszczak-Szubzda 2017]. Istnieje jednak przekonanie poparte wynikami licznych badań empirycznych, że problem nadużywania alkoholu przez osoby dorosłe występuje częściej w rodzinach wiejskich i małomiasteczkowych niż wielkomiejskich [m.in. Bartoszek, Kocka, Zielonka i in. 2016; Dzielska 2015]. Stanowi to potwierdzenie rezultatu uzyskanego w prezentowanym badaniu własnym. Pamiętać jednak trzeba, że prezentowany wynik dotyczy badania o charakterze deskryptywnym, odnoszącego się do wspomnień badanych recydywistów. Nie bez znaczenia jest tu także ich skłonność do deformowania przekazywanych informacji, koloryzowania, przemilczania niewygodnych dla nich faktów oraz przedstawiania siebie w jak najlepszym świetle [Czarkowski, Strzelec, 2020; Kamiński, 2006].

Niezależnie jednak od wielkości miejsca zamieszkania sytuacja psychospołeczna i ekonomiczna dzieci wychowujących się w rodzinach alkoholowych jest trudna. Dzieci te doświadczają zazwyczaj istotnych zaburzeń emocjonalnych i zakłóceń rozwoju psychofizycznego. Życie w chronicznym stresie, zagrożeniu i przemocy skutkuje zaburzeniami zachowania, w tym naruszeniami prawa i porządku publicznego. Dzieci alkoholików tworzą także grupę najwyższego ryzyka uzależnienia od alkoholu i narkotyków.

Wychowatem sie jako jedynak i do dziś żatuję, że nie mam rodzeństwa... Miałbym dzisiaj kogoś, na kogo mogę liczyć i komu mogę się wygadać. Moje dzieciństwo byto raczej smutne, bo wychowatem się w biedzie. Większość czasu spędzatem z matka. Bardzo dobrze się z niq dogadywatem, często ze soba rozmawialiśmy. Z tata té lubitem rozmawiać, ale to byto rzadkie, bo albo pracowat, albo byt pijany. Czasami pit bardzo dtugo, tygodniami $i$ w ogóle nie byto z nim kontaktu. Byt alkoholikiem. Miatem 15 lat, gdy to się u niego rozwinęto. Ojciec pracowat, ale połowe wypłaty przepijat, przy czym byt bardzo agresywny wobec matki i mnie. Mimo że nas bit, nie potrafitem go znienawidzić, ale każdego dnia modlitem się o zmiane na lepsze... I ona w końcu nastapiła, po dtugim czasie i ojciec wyszedt z alkoholizmu. Moi rodzice nie wiedzieli, jak spędzam czas poza domem, a nawet $z$ kim. Jakoś ich to nigdy nie interesowato. Chyba dlatego i ja zaczątem pić. Najpierw z kumplami, tak przy okazji, a potem więcej, po katach chowatem butelki z wódką. Wie Pani, ja to trochę wariat jestem po alkoholu i dlatego tu siedze, za agresję. [S.O. — 35 lat, kawaler, mieszkaniec dużego miasta, wykształcenie zawodowe, recydywista dwukrotny wyroki skazujące za pobicie, groźby karalne oraz rozbój]

Nadużywanie alkoholu przez dzieci i młodzież prowadzi do niekorzystnej zmiany ich trajektorii życiowej - hamuje karierę edukacyjną, a w dorosłości zwiększa ryzyko poważnego obniżenia zdolności funkcjonowania na rynku pracy. W rozwoju zaburzeń tożsamości i osobowości istotną funkcję pełni przenoszenie w dorosłe życie rodzinnych wzorców alkoholowych. Dom, w którym rządzi alkohol, a matka lub/i ojciec są od niego uzależnieni, nie daje dziecku 
poczucia bezpieczeństwa, zaburza proces jego wychowania i socjalizacji oraz uczy je rozwiązywania konfliktów w sposób przemocowy. To dom toksyczny, stresogenny, kojarzony z negatywnymi emocjami, lękiem i bólem, odarty z dzieciństwa. Dom, w którym trzeba szybko dorosnąć.

Mieszkałem z ojcem i matka, i trzema młodszymi braćmi. Moje dzieciństwo nie było szczęśliwe, bo brakowało mi rodziców. Ciagle ich nie byto $w$ domu. Ciężko pracowali i wszystko byto na mojej głowie. Bardzo wcześnie dorostem, bo musiałem i miałem do nich o to żal, ale dzisiaj myśle, że naprawdę nas kochali... Chyba bardziej bytem zwiazany z ojcem, bo mama piła i to nałogowo, ale robiliśmy wszystko, by chociaz nie wyrzucili ja za to z pracy... Myśle sobie, że czułem się wspótodpowiedzialny za rodzinę, bo razem z ojcem opiekowaliśmy się matka i młodszymi braćmi. $W$ dzieciństwie zbierałem znaczki pocztowe i etykiety z butelek po piwie. Ojciec po pracy zawsze pijat piwo i jak skończyt pić, to po prostu je odrywatem $i$ chowatem $w$ szufladzie... To moje uzależnienie alkoholowe, to chyba od mamy przejąem. [G.W. - 39 lat, kawaler, mieszkaniec średniego miasta, wykształcenie podstawowe, recydywista jednokrotny, wyroki skazujące za kradzież, rozbój oraz kradzież z włamaniem]

Mama zawsze była opiekuńcza, dużo pracowała. Każdy wolny czas, jaki miała, to starała się wykorzystywać tak, żebyśmy spędzali go razem. Tata lubit popić, miat swoje towarzystwo, więc różnie bywato. Jak wracat do domu, to chowaliśmy się po katach, bo tlukt co popadto, no talerze, szklan$k i$, co tam byto na stole i na mame się wydzierat. Raz to nawet telewizorem rzucit $w$ ścianę... To mama pilnowata, żebym nie wpadt $w$ jakieś zte towarzystwo i środowisko. Zabierała mnie też do kina, na imprezy jakieś takie - w dzieciństwie. Święta zawsze miło wspominam, bo zawsze babcia z braćmi przyjeżdzała do nas $i$ to byt taki czas, który najbardziej będe wspominat, bo tata babci się bat $i$ wtedy taki trzeźwiutki i czyściutki byt. A tak w ogóle, to nie było tam jakiś szczególnych wydarzeń, każdy miat swoje sprawy. Mama w końcu tez uzależniła się od alkoholu. Zmarła dziewięć lat temu, co prawda przez alkohol, ale nie piła już bardzo dtugi czas, tylko ogólnie na niewydolność krażeniowa. Ojciec się zapił na śmierć jakieś pół roku temu. Miałem problem, żeby na pogrzeb pojechać, ale udało się. [R.G. - 49 lat, wdowiec, mieszkaniec wsi, wykształcenie zawodowe, recydywista trzykrotny, wyroki skazujące za jazdę samochodem bez uprawnień i po alkoholu, groźby karalne, kradzież z włamaniem, pobicie]

\section{Postawy rodzicielskie i style wychowania w rodzinach pochodzenia}

W literaturze psychologicznej postawy są różnorako rozumiane, ponieważ są definiowane przez przedstawicieli różnych kierunków i dyscyplin naukowych, którzy odmiennie akcentują elementy struktury tego pojęcia [Mądrzycki 1977]. 
Niezależnie od sposobu jego ujmowania zawsze jest w nim obecny podmiot, który jest rodzicem i przedmiot jego oddziaływania — dziecko. Najbardziej rozpowszechnioną definicją postawy rodzicielskiej i w moim odczuciu najtrafniejszą jest ta, którą sformułowała Maria Ziemska [1973, s. 33]. Postawa rozumiana jest przez tę autorkę jako „nabyta struktura poznawczo-uczuciowo-wolicjonalna ukierunkowująca zachowanie się rodziców wobec dziecka", składająca się z trzech komponentów:

- emocjonalnego, odnoszącego się do stosunku uczuciowego rodziców do dziecka i stanowiącego najistotniejszy element postawy rodzicielskiej, ukierunkowujący pozostałe komponenty;

- poznawczego, na który składają się przekonania i poglądy rodziców dotyczące dziecka;

- behawioralnego, związanego z przejawianymi przez rodziców zachowaniami wobec dziecka.

Postawy rodzicielskie są kształtowane temporalnie i wieloczynnikowo. Najsilniej wpływają na nie wzorce postaw, ale także wzory relacji społecznych wyniesione $\mathrm{z}$ rodziny pochodzenia, jakość relacji między małżonkami/partnerami, cechy osobowościowe, charakterologiczne i temperamentalne rodziców oraz cechy wrodzone, zdolności i właściwości dziecka [Ziemska 1973]. Zdaniem czołowych polskich badaczy postaw rodzicielskich, takich jak Józef Rembowski czy Maria Ziemska, najbardziej istotnym przejawem postawy rodzicielskiej jest ładunek uczuciowy. Pomaga on zidentyfikować rodzaj postawy oraz wyjaśniać jej uwarunkowania. Postawy cechują się plastycznością, co oznacza, że mogą być $\mathrm{w}$ różnym stopniu utrwalone. Postawy trwałe są kształtowane w toku bezpośrednich i wielokrotnych kontaktów rodziców z dzieckiem. Wraz z jego rozwojem zmieniają się także wobec niego postawy rodziców, gdyż poszczególne komponenty postawy mogą się zmniejszać, zanikać lub kształtować [Mądrzycki 1977].

Rodzice mogą reagować w różny sposób i z różną siłą na zachowania dzieci, a ich reakcje są określane jako pozytywne lub negatywne. Pozytywne postawy rodzicielskie niemal zawsze przejawiają się w wyważonym reagowaniu rodziców na poczynania dziecka, zaangażowaniu i chęci działania na rzecz jego dobra. Okazują mu oni zaangażowanie i zrozumienie oraz podtrzymują jego dążenia do samodzielności, autonomii, kreatywności i samostanowienia. Pozytywne, pełne ufności postawy rodzicielskie wspierają wszechstronny rozwój dziecka oraz są czynnikiem chroniącym je przed zachowaniami ryzykownymi. Dają dziecku poczucie bezpieczeństwa, podnoszą jego wartość własną, uczą wyrażania i rozpoznawania uczuć swoich i cudzych oraz kształtują empatię i wrażliwość na potrzeby innych ludzi. Z kolei postawy rodzicielskie negatywne wiążą się z przejawianiem przez rodziców chłodu emocjonalnego oraz różnego rodzaju form agresji wobec dziecka (m.in. poniżanie, stosowanie kar cielesnych lub unikanie kontaktu, brak zainteresowania jego sprawami i problemami).

Percepcja postaw rodzicielskich przez dzieci wywiera znaczący wpływ na ich przystosowanie społeczne. Badania przeprowadzone przez F.N. Cox i Patricie M. Leaper (1961) wykazały, że dzieci odrzucone przez rodziców mają ewidentne 
trudności w przystosowaniu społecznym i emocjonalnym. Z kolei Naomi M. Serot i Richard C. Teevan (1961) udowodnili, że na dobre przystosowanie społeczne dzieci wpływ ma ich pozytywne postrzeganie postaw rodzicielskich. Odnotowano także pozytywną korelację pomiędzy pozytywnymi postawami ojców a ekstrawersją chłopców oraz niedostatkiem miłości ojcowskiej, a wycofującym się zachowaniem synów [Siegelman, za: Plopa 2007]. Inne badania wykazały natomiast, że prawidłowe przyswojenie norm społecznych przez synów warunkowane jest częstością kontaktów z ojcami i pozytywnym odbiorem ich postaw. Chłopców negatywnie postrzegających postawy ojców charakteryzuje konfliktowość i większa zależność. Z kolei poczucie odrzucenia przez jednego lub obojga rodziców cechuje chłopców wykazujących zachowania agresywne. Postrzeganie przez synów postaw ojców jako pozytywne, przekłada się na ich poprawne relacje z rówieśnikami [Plopa 2007]. Interesujący wynik uzyskano także w odniesieniu do postrzegania postaw matek. Otóż chłopcy związani emocjonalnie tylko z matkami, byli od nich silnie zależni [Schaefer, za: Plopa 2007].

Jak wynika z analizy tekstów pozyskanych z wywiadów i wytworów pisemnych badanych recydywistów, postawy wychowawcze ich rodziców nie były modelowe, jednak znacząca część badanych recydywistów postrzegała je jako pozytywne. Czytając zapisy, odniosłam wrażenie, że badani byli świadomi obciążeń rodzinnych (m.in. nadmiar lub brak pracy, wielodzietność, problemy w zabezpieczeniu ekonomicznym rodziny) oraz ich konsekwencji rzutujących na jakość relacji wewnątrzrodzinnych oraz generujących nerwowe reakcje rodziców na dziecięce zachowania, a niekiedy ich brak. W swoich narracjach przyznawali bowiem, że rodzice ich kochali, otaczali troską, zrozumieniem i wspierali na tyle, na ile mogli, ale życie codzienne wymuszało pośpieszne i pobieżne relacje, a to $\mathrm{z}$ kolei powodowało, że ich wpływ wychowawczy nie był znaczący.

Moja rodzina byta duża, rodzice i sześcioro dzieci. Rodzice pracowali na dniówki, ale całe wieczory byliśmy ze soba, najczęściej w trakcie kolacji. Rozmawialiśmy na różne tematy, czasem razem ogląaliśmy telewizję. $Z$ mama miatem gorsze relacje niż z tata. Z nim rozumieliśmy się, jeździliśmy razem na ryby, no i motoryzacja, to była nasza pasja. Rodzice zawsze chcieli dla mnie dobrze, zwłaszcza tata, który powtarzat mi, że powinienem szkołę skończyć i usamodzielnić się. W zasadzie to nas częściej nagradzali i chwalili. Kary byty, a jakże. Gdy dostałem jedynkę w szkole, to za karę tata kazal mi przeczytać ksiazzkę... Do dziś ja pamiętam „Pinokio" (smiech). Myślę sobie, że dzieciństwo miatem dobre i wszystko uktadało się tak, że miałem szansę, być kimś w życiu, ale potem jedna niezapłacona grzywna, trzydzieści dni odsiadka, złe towarzycho i nakręcito się tak, że zostatem kryminalista... Kocham bardzo moich rodziców i ich szanuje, a teraz to jeszcze bardziej, bo za nimi tęsknię. Nawet palenie dla nich rzucitem. No, dla siebie też... [A.P. - 25 lat, kawaler, mieszkaniec wsi, wykształcenie zawodowe, recydywista jednokrotny - wyroki skazujące za niezapłaconą grzywnę, kradzież i paserstwo] 
Jak bytem młody, to bytem rodzicom postuszny, a oni nie stawiali jakichś szczególnie trudnych wymagań. Jak miatem problem, to starali się mi pomóc, jak tylko mogli. Jak już byłem starszy, to trochę się zmieniło, stałem się bardziej buntowniczy, bardziej się stawiatem, nie stuchatem się już mamy, a ona nie nalegała. Ojciec się denerwowat, jak coś odpyskiwatem mamie, ale jako takich kłótni to raczej nie byto. Oni kochali nas, ciężko pracowali, aby jakoś nam się żyto. Z czasem było gorzej, bo ojciec zacząt więcej pić, więc i brakowało pieniędzy, dlatego potem pomagatem im finansowo. Czułem, że jestem im to, w jakiś sposób winien. Wychowywali nas raczej swobodnie, mieliśmy jakieś reguły czy tam zasady, których musieliśmy się trzymać, ale zawsze z nami rozmawiali i tlumaczyli, dlaczego właśnie tak ma być. [K.L. — 43 lata, kawaler, mieszkaniec średniej wielkości miasta, wykształcenie zawodowe, recydywista trzykrotny, wyroki skazujące za kradzieże i kradzież z włamaniem]

Implikacją postaw rodzicielskich o zabarwieniu negatywnym są zaburzenia mogące wystąpić we wszystkich sferach rozwojowych dziecka: intelektualnej, fizycznej, emocjonalnej i duchowej. Mogą one niekorzystnie wpływać również na proces jego adaptacji społecznej, szczególnie w sferze interakcyjnej i komunikacyjnej. Mogą także deformować proces kształtowania się kompetencji społecznych oraz sposobów radzenia sobie w sytuacjach trudnych [Plopa 2007]. Tego rodzaju postawy rodziców wywołują u dziecka obniżenie poziomu samooceny i poczucia wartości własnej, deprywację potrzeby szacunku, miłości i przynależności. W konsekwencji negatywne postawy rodziców stanowią czynnik ryzyka i mogą skutkować niedostosowaniem społecznym dziecka.

Narracje niemal $1 / 3$ badanych recydywistów świadczyły o negatywnych postawach rodzicielskich, o dziecięcej samotności i lęku przed karą. Negatywne postawy rodzicielskie skutkowały niechętnymi, często nieżyczliwymi, a nawet agresywnymi reakcjami rodziców na ich zachowania, co przejawiało się w ignorowaniu ich potrzeb, wzmożonym kontrolowaniu i stosowaniu kar za niedostosowanie się do postawionych przez nich zakazów czy nakazów oraz ciągłym krytykowaniu. Wypowiedzi badanych recydywistów wskazują, że traktowane w ten sposób dzieci, w dorosłości nie utrzymują zazwyczaj dobrych relacji $\mathrm{z}$ rodzicami.

Moja rodzina była mała, jeśli można tak powiedzieć, bo byłem tylko ja i moi rodzice. Czasu razem nie spędzaliśmy, bo rodzice ciagle pracowali, więc widzieliśmy się tylko wówczas, gdy wracali z pracy. Wtedy siadaliśmy razem, jedliśmy kolację, no i co najwyżej opowiadaliśmy sobie, jak to nam miną dzień i tyle. Jakoś z żadnym z nich nie byłem szczególnie zwiazany. Bytem wychowywany można powiedzieć, że surowo. Musiałem przestrzegać zasad, które panowaly w domu. Nie wiem, czy moje dzieciństwo było szczęśliwe, raczej tak, chociaż ojciec ciagle mi dogryzat i mówit, że nic ze mnie nie będzie, że życie da mi popalić... Jak bytem maty, to się 
liczytem z rodzicami, zreszta chyba nie miatem wielkiego wyboru, bo jak się nie stuchatem, to wchodzit ojciec z pasem i przemawiat mi do rozsadku i musiatem się ich stuchać. A potem to wiadomo, bytem starszy i jak widziatem, że coś się szykuje, to po prostu uciekałem, ale bywało też tak, $\dot{z}$ e się stawiatem. To akurat bardziej dziatało na matke, bo odpuszczała. $Z$ ojcem niestety nie przechodzity takie rzeczy. Rodzice nie interesowali się, z kim się kumpluję, ważne byto to, że nie miałem zich powodu żadnych klopotów, a tak to nic do nich nie mieli. Zreszta rzadko ich widywali, bo nikt do mnie nie przychodzit, więc nie wiedzieli też i z kim tam się spotykam, chyba że ktoś coś im powiedziat. Kiedyś z rodzicami miatem nawet dobre stosunki, kontakty, ale aktualnie to pogorszyty się i bardzo rzadko się widzimy $i$ styszymy, bo do mnie teraz nawet nie zadzwonia... [P.C. 37 lat, kawaler, mieszkaniec małego miasta, wykształcenie podstawowe, recydywista dwukrotny, wyroki skazujące za kradzieże]

Analiza wspomnień badanych recydywistów pozwoliła na wyodrębnienie obojętnej postawy rodzicielskiej, która tak jak postawa negatywna - jest niekorzystna. Ma podobną jak do niej charakterystykę, z tym jednak, że postawy obojętne rodziców wobec dziecka skutkują silniejszym wpływem rówieśniczym. $\mathrm{W}$ powiązaniu z zaburzeniami występującymi w obrębie systemu rodzinnego, tego typu postawy przyczyniają się w sposób bezpośredni do poszukiwania przez dziecko akceptacji, szacunku i poczucia bezpieczeństwa poza rodziną, a często w negatywnych grupach rówieśniczych. Dzieci doświadczające obojętnych postaw rodzicielskich są zagubione, niepewne, obciążone licznymi deficytami, w tym brakiem empatii i umiejętności rozpoznawania i wyrażania emocji u siebie i innych, a w dorosłości nie potrafią kształtować i utrwalać więzi rodzinnych. Wszystko to prowadzi do nakręcania się spirali niedostosowania społecznego, a często rozpoczęcia kariery przestępczej.

Wychowatem się w pięcioosobowej rodzinie (ja, dwie siostry i rodzice). Rodzice byli tak jakby obok nas. Sami wszystko sobie organizowaliśmy, jedzenie też, bo jedna siostra dobrze gotowata. Czasu nie spędzaliśmy wspólnie z rodzicami, bo oni dużo pracowali i nie mieli dla nas czasu. Jak bytem maty, to się wokót sióstr patętatem, a one zajmowaty się soba, bo byty ode mnie dużo starsze. Najlepsze byty Święta, bo wtedy to rodzice $w$ domu byli. Jak tak patrze z perspektywy czasu, to moje dzieciństwo byto ponure. Nie byto $w$ żadnym z nas radości, takiego zadowolenia, że jesteśmy rodzina. Rodziców stuchatem, bo ich kochatem, ale oni nie mieli czasu na to, by nas jakoś specjalnie wychowywać. Moich kolegów nie znali i nigdy nie pytali, z kim się zadaję. Każdy w naszym domu robit, co chciat. Myślę sobie, że wptynęło to na nas tak, że nie jesteśmy ze soba zżyci. [J.K. - 39 lat, rozwiedziony, mieszkaniec miasta średniej wielkości, wykształcenie zawodowe, recydywista trzykrotny, wyroki skazujące za kradzieże i napad z użyciem niebezpiecznego narzędzia] 
$W$ dzieciństwie mieszkatem z rodzicami i dwoma braćmi $w$ kamienicy. Dzieliłem pokój razem z bratem. Najstarszy brat miat swój pokój. Większość czasu z braćmi spędzałem. Lubiliśmy razem psocić. Rodzice handlowali ubraniami $i$ wychodzili $z$ domu rano, a wracali przed wieczorem. Ojciec zawsze był zapracowany, mama też i mato z nimi gadaliśmy. Na nic jednak narzekać nie mogłem. Rodziców co prawda nie było całymi dniami, ale niczego mi nie brakowato. Gary jedzenia stały. Mama zawsze w nocy baniak jakiejś zupy zrobiła. Nas też szybko podszkolita, jak sobie coś ugotować. Dobrze było, ale bez bliskości, takiej myśle uważności, jakbyśmy dla rodziców przezroczyści byli. [D.Z. - 36 lat, rozwiedziony, mieszkaniec dużego miasta, wykształcenie zawodowe, recydywista dwukrotny, wyroki skazujące za kradzieże oraz posiadanie i rozprowadzanie narkotyków]

Innym pojęciem odnoszącym się do wpływu rodzicielskiego jest styl wychowania w rodzinie, rozumiany jako względnie trwały, określony stosunek rodziców do dziecka, przejawiający się w sposobie egzekwowania przez rodziców jego praw i obowiązków (podejmowane przez rodziców decyzje, ich zachowania i postawy) oraz w stosowanych wobec niego metodach wychowawczych [m.in. Harwas-Napierała 2006; Obuchowska 2009; Napora, Kozerska 2010]. Jest to naturalne oddziaływanie rodziców na dzieci, stanowiące wyznacznik jakości i charakteru wywieranego wpływu [Liberska 2007, s. 56]. Podstawowymi elementami stylu wychowania są: jakość i typ wspomagania rozwoju, formy i ilość czasu spędzanego z dzieckiem, sposoby jego kontrolowania i osiągania wyznaczonych celów wychowawczych, specyfika podziału ról społecznych i obowiązków w rodzinie oraz określony katalog norm i reguł wewnątrzrodzinnych [m.in. Harwas-Napierała 2006; Napora-Kozerska 2010]. Styl wychowawczy identyfikowany jest głównie na podstawie charakteru relacji między rodzicami a dziećmi, będących w sprzężeniu zwrotnym cech i zachowań rodziców, podejmowanych przez nich oddziaływań wychowawczych oraz efektów rozwojowych dziecka [Praszkier 1988].

Podstawą klasyfikacji stylów wychowania jest wymiar stosunku emocjonalnego rodziców do dziecka, wskaźnikowany poziomem zainteresowania jego potrzebami, rodzajem okazywanych mu uczuć oraz sposobem jego kontrolowania (m.in. Borecka-Biernat 1992 i 2006; Przetacznikowa, Makieło-Jarża 1977).

Strategie wychowywania i kontroli przejawiają się poprzez formy fizycznych i werbalnych interakcji rodziców z dzieckiem. Rodzice mogą kontrolować dziecko z różnym nasileniem. Może to być kontrola nadmierna (ścisły monitoring działań i zachowań dziecka), kontrola wyważona (oparta na zasadzie ograniczonego zaufania) lub kontrola niedostateczna (brak zainteresowania poczynaniami dziecka). Klimat rodzinny o cechach patologizujących (kłótnie, stosowanie przymusu, zachowania agresywne, okazywana wrogość) wnosi istotny wkład w powstawanie zaburzeń rozwojowych u dzieci, a zwłaszcza agresywności i zaburzeń psychicznych, Wpływa także na podejmowanie przez dzieci zachowań ryzykownych, w tym przestępczych oraz związanych z nadużywaniem środków psychoaktywnych [Barnes, Farrel 1992]. 
Klasyfikacji stylów wychowania jest wiele. Pierwsza, klasyczna już klasyfikacja została opracowana na podstawie wyników badań prowadzonych przez Kurta Lewina, Rona Lippitta i Roberta K. White'a [1939], którzy wyodrębnili trzy podstawowe style: demokratyczny, liberalny i autokratyczny. W prezentowanym badaniu została przyjęta właśnie ta, pierwotna klasyfikacja stylów wychowania.

Osiąganie przez dziecko wyższego poziomu moralnego wiąże się ze spójnym i adaptacyjnym stylem interakcji rodzinnych [Powers 1988; Bakken, Romig 1994] oraz środowiskiem rodzinnym wymagającym, ale wspierającym dziecko również w sytuacjach dylematów moralnych [Walker, Taylor 1991]. Pozytywny wpływ na rozwój dziecka wywiera także stosowanie przez rodziców demokratycznego stylu wychowania [Speicher 1982, za: Kohlberg 1984]. Styl ten częściej prezentują rodzice znajdujący się na wyższych poziomach rozwoju moralnego [Powers 1988]. W związku z tym postawiono tezę, że metody/praktyki wychowania mogą pełnić funkcję pośredniczącą między rozwojem rozumowania moralnego rodziców i ich dzieci. Interesujący wynik uzyskano w odniesieniu do stosowanej przez rodziców praktyki polegającej na wskazywaniu konsekwencji dokonywanych wyborów (działań) oraz kształtowaniu u dzieci umiejętności dostrzegania i analizowania zdarzeń/sytuacji z perspektywy innych osób [Hoffman, Saltzsein 1967; Buck, Walsh, Rothman 1981; Boyes, Allen 1993]. Otóż stwierdzono, że taki sposób wychowywania dzieci pozwala na osiąganie przez nie wyższego poziomu moralnego. Sprzyja temu także miłość rodzicielska. Z kolei rodzice odrzucający swoje dzieci cechują się niedojrzałym myśleniem moralnym [Palmer, Hollin 1996, 1997].

Interesujące badania porównawcze młodzieży gimnazjalnej prawidłowo przystosowanej i zaburzonej, autorstwa E. Wysockiej i B. Ostafińskiej-Molik [2014, s. 142-152], dotyczyły oceny jakości funkcjonowania i typu rodziny w kontekście zróżnicowanych typologicznie zaburzeń adaptacyjnych zaobserwowanych u badanej młodzieży. Wykazały one, że dla procesu dewiacyjnego największe znaczenie mają cechy rodziny chaotycznej (brak więzi pomiędzy członkami rodziny, konflikty wewnątrzrodzinne, brak poczucia bezpieczeństwa), następnie rodziny uwikłanej (nieprawidłowe i splątane reakcje, wykorzystywanie dziecka do zaspokajania potrzeb rodzica) i rodziny władzy (wymaganie posłuszeństwa wobec rodziców, restrykcyjna kontrola rodzicielska), zaś najmniejsze — rodziny nadopiekuńczej (wyręczanie dziecka i sprawowanie nadmiernej opieki). Wyniki cytowanych badań nie są wprawdzie jednoznaczne, ale statystycznie potwierdzono silniejsze związki w obszarach:

- zaburzeń eksternalizacyjnych z postawami matek (rodzina nadopiekuńcza);

- zaburzeń internalizacyjnych z postawami ojca (rodzina chaotyczna, uwikłana i władzy);

- zaburzeń mieszanych z nieprawidłowymi postawami obojga rodziców (chaotyczna i władcza matka oraz władczy ojciec).

Badania dotyczące znaczenia rodziny dla rozwoju moralnego dziecka przeprowadzili Kirby Deater-Deckard, Kenneth A. Dodge [1997] oraz Gerald 
R. Patterson [1982], którzy analizowali wpływ czynników społecznych (klasa społeczna, w której lokuje się rodzina, wielodzietność, niepełność rodziny, przestępczość rodziców) na jakość rodzicielstwa. Okazało się, że wiele z nich odpowiada za wzrost ryzyka przestępczości, co potwierdziły również wyniki badania Davida P. Farringtona [1996] oraz Michaela Ruttera, Henriego Gillera, Ann Hagell [1998]. Co więcej, zbadano także relacje pomiędzy poziomem rozumowania moralnego rodziców i ich dzieci [Speicher 1994; Walker, Taylor 1991]. W tym obszarze analiz empirycznych wykryto słabe i niekonsekwentne związki. Trudno bowiem wskazać na bezpośredni związek między poziomem rozwoju moralnego rodziców i dzieci, z uwagi na większą dojrzałość rodziców (m.in. wiek, doświadczenia życiowe czy poziom rozwoju poznawczego), którzy znajdują się w znacznie bardziej zaawansowanych stadiach rozwoju rozumowania moralnego niż ich dzieci.

Badania Matczak i Jaworowskiej [2003] wykazały z kolei silny związek między poziomem kompetencji społecznych rodziców a trudnościami w przystosowaniu się dzieci. Dzieci z rodzin wieloproblemowych wskutek złych wzorców socjalizacyjnych, wynikających między innymi z niskiego poziomu kompetencji społecznych rodziców oraz przyjmowania przez nich unikowych lub emocjonalnych stylów radzenia sobie ze stresem, wykazują wiele przejawów niedostosowania społecznego [Nowak 2011]. Popełniają czyny przestępcze powiązane z agresywnymi lub unikowymi wzorcami zachowań rodziców, a często powielają wzorce zachowań przestępczych, prezentowane przez członków ich własnych rodzin.

Było nas czworo. Ojczym, matka, ja i brat. Matka rozeszła się z moim ojcem, gdy bylem mały. Nie pamiętam wczesnego dzieciństwa, a później bytem $w$ zaktadzie wychowawczym, więc z rodzina widywatem się rzadko. Dzieciństwo miatem chyba dość udane, chociaż byty też przykre momenty. Pamiętam, jak mój biologiczny ojciec znęcat się nad moja matką. Matka rozwiodła się z ojcem i zwiazała z ojczymem, jak miatem 6 lat. Nie utrzymywatem zbyt dobrego kontaktu z ojcem. Wiem, że pare razy siedziat i później próbowat sobie ułożyć życie, ale nie wychodziło mu. To, że ja co jakiś czas tu wracam, to chyba jakaś rodzinna klątwa jest... [A.H. 42 lata, rozwiedziony, mieszkaniec średniego miasta, wykształcenie podstawowe, recydywista sześciokrotny, wyroki skazujące za kradzieże]

W części badania dotyczącego postaw rodzicielskich i stylów wychowania prezentowanych przez rodziców badanych recydywistów [Nowak 2017b], na podstawie retrospekcyjnych wspomnień z dzieciństwa wyodrębniono cztery kategorie postaw rodzicielskich, powiązanych z określonymi stylami wychowania:

- postawa kochająco-wyrozumiała (,gorąca”) — demokratyczny styl wychowania;

- postawa obojętno-odrzucająca („letnia”) - styl liberalny;

- postawa karząco-dyscyplinująca (,zimna”) — autokratyczny styl wychowania;

- postawa ambiwalentna („,chwiejna”) — niekonsekwentne oddziaływanie. 
Badani recydywiści wskazywali najczęściej na kochająco-wyrozumialą postawę wychowawczą rodziców (,,postawa gorąca” - 38,4\%). W retrospektywnych opisach własnego dzieciństwa usprawiedliwiali oni nieobecność lub brak zainteresowania rodziców. Jedni z nich podkreślali, że nie byli związani z ojcem z uwagi na jego zapracowanie, inni natomiast twierdzili, że nieobecność ojca w ich życiu wzmacniała ich związek z matką lub wskazywali na rolę opiekuńczą i silny wychowawczy wpływ dziadków.

Moje dzieciństwo było raczej szczęśliwe, nie moge powiedzieć, że było jakieś patologiczne, że była tam przemoc czy coś takiego. Więc raczej szczęśliwe było. Myśle, że najbardziej zwiazany bytem z matka, bo ojca caty czas nie było, bo pracowat. Byt jedynym żywicielem rodziny, ale wiem, że oboje mnie kochali, byli mi życzliwi, pozwalali na wiele, dbali o mnie... [B.J. - 29 lat, kawaler, mieszkaniec dużego miasta, wykształcenie zawodowe, recydywista trzykrotny, wyroki skazujące za kradzież z włamaniem, kradzieże samochodów, wymuszenia, pobicie]

Pochodze z małej robotniczej rodziny. W domu było nas czworo: ojciec, matka, ja i młodsza siostra. Najczęściej razem spędzaliśmy czas, wyjezdżajac do rodziny za miasto, na święta, urlopy $i$ wakacje. Często razem z ojcem lub babcia wybieraliśmy się zwiedzać Warszawe lub po prostu chodziliśmy do kina. $W$ dzieciństwie najbardziej kochałem wiecznie zapracowana matke, ale to wtaśnie dziadkowie i babcie rozwijaty we mnie wszelkie zainteresowania i ciekawość otaczajacego życia. Dzięki nim wcześniej niż rówieśnicy nauczyłem się liczyć, czytać i pisać, a będac ośmiolatkiem, wykazywatem duża samodzielność w poruszaniu się po Warszawie. Dzieciństwo wspominam jako barwne i pogodne. Rodzice starali sie mnie nie karać, a raczej uczyć krytycznego rozumienia $i$ wystrzegania się raz popetnianych błędów. Od najmłodszych lat wpajano mi zasady dobrego wychowania i obowiazku postuszeństwa wobec osób starszych. [M.L. - 45 lat, żonaty, mieszkaniec dużego miasta, wykształcenie średnie, recydywista jednokrotny — wyroki skazujące za kradzieże]

Mieszkaliśmy na [...]. Zawsze po przyjściu ze szkoły byt obiad i odrabianie lekcji. Potem była gonitwa z siostra po podwórku. Czasami mieliśmy jakieś atrakcje, wypady poza miasto, ale to rzadko. Mieliśmy też domek taki na ogródkach działkowych, to czasem bawiliśmy się tam z siostra, a rodzice mieli święty spokój i tylko patrzyli na nas, byśmy czegoś nie zmajstrowali. Kochatem bardzo mame, ale to tata byt dla mnie wzorem. Takiego maczo, bo byt silny, trenowat pitkę. Później przestal, bo jeden z piłkarzy niechcacy kopnat go w kolano i on już nie mógt grać. Później mieszkaliśmy koło bazaru [...]. Ojciec specjalnie chodzit na ten bazar, prowokowat takich ze wsi, brat ich dwóch, trzech i pod tym domkiem, w którym mieszkaliśmy, bit się z nimi. Specjalnie, a mama stała i składała ręce do Boga (śmiech). 
Krzyczała, Kaziu uspokój się! A ja wracałem ze szkoły z neseserkiem i bitem tacie brawo, bo przeważie wygrywat. Ojciec miat fach $w$ ręku, ale byt taki raczej chuligan. Lubit się bić. Liczyłem się z jego zdaniem, bo byt konkretny. Mama musiała mi powiedzieć coś parę razy, jak ja latatem na podwórku, a ojciec tylko wyjrzat, spojrzat i ja od razu wracałem. No ojciec, to ojciec, nie? W domu się działo tak, że jak danego dnia byt humor i pogoda, to wszystko nam byto wolno. Za naukę czy za jakieś przewinienie, to $w$ siedzenie od ojca dostawatem, a jak chciatem wędke czy motorower, to rodzice mówili, że jak będa dobre oceny, to będzie wędka, no i była. Rodzice zwykle znali moich kolegów, ale niektórych ukrywatem, bo mieli jak na tamte czasy za dużo kasy. Później mama i tata wypytywali, skąd oni to maja i dlaczego ja chcę się z nimi kolegować. Dlatego nie wszystkich znali. Jak chciałem wyjść z kumplami na miasto, to mama pytała, z którymi. Jeżeli zaczątem kręcić i mama wyczuła, to mówiła nie, dzisiaj nie masz wychodnego. Albo jak przyjdzie taki, i taki po ciebie, to dopiero pójdziesz. [J.K. - 57 lat, rozwiedziony, mieszkaniec dużego miasta, wykształcenie zawodowe, recydywista pięciokrotny, wyroki skazujące za jazdę pod wpływem alkoholu, kradzieże, kradzież z włamaniem]

Wyżej zacytowane wypowiedzi oraz inne narracje osób badanych wskazują na tendencję do obrony obrazu osób znaczących, ograniczającą ich realistyczną ocenę środowiska rodzinnego [m.in. Bradshaw 1994; Nowak 2017b]. Inne retrospektywne wynurzenia świadczą z kolei o niepowodzeniu oddziaływań wychowawczych opartych na postawie kochająco-wyrozumiałej. W takich przypadkach narracje osób badanych wskazują na dominację pozarodzinnych źródeł ich niedostosowania społecznego.

Jak bytem młodszy, to rodzicom dobrze szło. Kochali nas, rozumieli nasze problemy i starali sie jak mogli, byśmy wyszli na ludzi. Nic złego o nich nie mogę powiedzieć. To byli dobrzy rodzice. Ale później się trochę popsuło, bo bytem trochę starszy i buntowatem się. Miatem znajomych z osiedla. Dużo razem spędzaliśmy czasu. Kradło się, no bo się nie zastanawiato nad tym, co się robito. Rano wychodziłem $z$ domu, a na wieczór wracałem. Mieszkałem w takiej dzielnicy, gdzie trafia się do poprawczaka, a później do więzienia. Tak właśnie było ze mna. [P.C. - 28 lat, kawaler, mieszkaniec dużego miasta, wykształcenie podstawowe, recydywista dwukrotny, wyroki skazujące za posiadanie narkotyków, wymuszenia i oszustwo]

Jestem jedynakiem. Rodzice byli dla mnie przykładem, ale nie mogli poświęcić mi za dużo czasu. Byli zapracowani - matka dentystka, ojciec dentysta protetyk. Pomimo to dzieciństwo moje byto bardzo szczęśliwe. Rodzice mnie rozpieszczali. No, wie Pani, oni zarabiali bardzo dobrze, miatem wszystko, co chciatem. Najbardziej kochatem matke, bo to ona mnie bardzo kochata i rozumiata. Z tej dobroci na wszystko mi pozwalata. To, ze jestem tutaj, to wynik moich ciagot do ryzyka, hazardu i chyba 
już taki z natury jestem, że frajdę sprawia mi oszukiwanie ludzi i czerpanie z tego korzyści finansowych. Tak zdobyta kasa mnie bardzo cieszy. [K.K. — 45 lata, żonaty, duże miasto, wykształcenie wyższe, recydywista dwukrotny, wyroki skazujące za oszustwa]

Badani recydywiści równie często wskazywali na postawę rodzicielską ambiwalentną (postawa „chwiejna” — 1/3 ogółu osób badanych), powiązaną z niekonsekwentnym oddziaływaniem rodzicielskim, kształtującą u dzieci poczucie osamotnienia, krzywdy, niesprawiedliwości. Dzieci te są częściej niedostosowane społecznie, wycofane, bezradne, zdane na wpływy rówieśnicze i przypadkowe zrządzenia losu.

Moje dzieciństwo może nie do końca było szczęśliwe, ale ogólnie dobrze było. Mama taka wylewna jest, taka bardziej czuła, kochająca. Ojciec tak tego nie pokazuje. Jak tata mi dawał kare, to mama mi pozwalała, robić to, czego zabronit mi ojciec, a jak mama mnie karała, to tata mi odpuszczat. No i nauczytem się nimi tak manipulować, że do końca nie zdawali sobie sprawy z tego, że z kumplami obrabiamy domy. Wielkie oczy zrobili wtedy, gdy zabrali mnie do poprawczaka. [J.L. - 28 lat, kawaler, mieszkaniec średniego miasta, wykształcenie gimnazjalne, recydywista jednokrotny, wyroki skazujące za kradzież z włamaniem, jazdę samochodem bez uprawnień oraz rozbój]

Moja rodzina była wielodzietna. Siedmioro nas byto, ale jedno dziecko zmarło... Żyliśmy razem, ale jakby osobno, bo każdy z nas miat swoje zajęcia. Z mama żyłem bardzo dobrze, z ojcem gorzej. Bytem oczkiem w głowie mamy, a ojciec się zawsze czepiat i mało co go interesowało. Poza tym ojciec byt zawsze porywczy, a mama nas broniła. Z mama mam bardzo dobry kontakt, a z ojcem... to sam nie wiem, bo siedzi tutaj, dwa piętra wyżej. [T.R. — 24 lat, kawaler, mieszkaniec miasta średniej wielkości, wykształcenie podstawowe, dwukrotny recydywista, wyroki skazujące za pobicie i wymuszenie rozbójnicze]

Nie znam swojego biologicznego ojca. Wychowywatem się z ojczymem po tym, jak mama odzyskała prawa rodzicielskie do mnie i moich dwu sióstr. Miałem wtedy 12 lat. Jak sięgnę pamięcia wstecz, to wydaje mi się, że moje dzieciństwo byto umiarkowanie szczęśliwe..., częściej byto słabo, nijako... Nie mieliśmy pieniędzy, mama była na rencie, a jeść się chciało. Ojczym byt w porządku, ale nie zarabiat kokosów. To byt bardzo fajny facet, ale już od dawna nie żyje. Ale pomimo tego, że nie byto kasy, to byto nieźle. Miatem swoje humory, ale bytem szczęśliwy. Nieszczęśliwy byłem tylko wtedy, gdy byliśmy w domu dziecka, ale to byto krótko. Spędziliśmy tam tylko, a może aż, rok [...] Ja chodzitem swoimi ścieżkami i specjalnie nie liczyłem się ze zdaniem rodziców - zawsze miałem swoje... Mama udawała, że nic nie widzi i nic nie styszy, ale ojczym się denerwowat i często się kłóciliśmy, 
ale zawsze ich szanowałem. Mama była raczej uległa, wolała przymykać oczy na niektóre sprawy, albo kryła mnie przed ojczymem, bo on często stosowat kary. Byłem wściekty, ale zawsze wiedziałem, za co je dostaję. [H.D. - 46 lat, rozwiedziony, mieszkaniec dużego miasta, wykształcenie zawodowe, recydywista pięciokrotny, wyroki skazujące za oszustwa, pobicie oraz kradzieże]

Na postawy wychowawcze obojętno-odrzucające (postawa „letnia”) wskazało z kolei 19,2\% badanych. Doświadczały jej najczęściej osoby wychowujące się na wsi. W percepcji badanych recydywistów tego typu postawy wykazywali najczęściej ich ojcowie, ale zdarzały się także sytuacje, gdy to matka była rodzicem nieczułym, wręcz obojętnym wobec własnego dziecka.

Gdy miałem 12 lat, moi rodzice się pierwszy raz rozeszli, potem wrócili do siebie i znowu sie rozeszli, praktycznie caty czas bytem tylko z ojcem, $z$ nim bytem zwiazany. Z matka nie było takiego kontaktu. Swoje dzieciństwo uważam raczej za spetnione, ja tam na nic nie narzekatem. Liczytem się zawsze ze zdaniem ojca, z matki już niekoniecznie, szczególnie jak po pierwszym rozstaniu z ojcem do nas wróciła. Zawsze robilem to, co uważałem za stuszne. Mama bardziej mnie zbywała, nie zajmowata się mna zbytnio. Równie dobrze mogłoby mnie nie być. Nie było ani kar, ani nagród, ani tlumaczenia. Jak mówitem, mama mnie bardziej zbywała, niż wychowywata, no to ja bardziej z tata ustalatem, co miatem robić. [J.S. 26 lat, kawaler, mieszkaniec wsi, wykształcenie gimnazjalne, recydywista jednokrotny, wyroki skazujące za wyłudzenia oraz rozbój]

Miałem koleżanki i kolegów, ale do żadnej grupy nie należałem. Spotykaliśmy się, jeździliśmy nad rzeke, rozpalaliśmy ognisko. Była z nas taka grupka z 10 osób. To czasem na wagary się chodziło, po prostu kolegowaliśmy się. No, wiadomo, koleżanki prace domowe za nas odrabiaty. Rodzice nie mieli nic przeciwko, ich stosunek do mnie byt raczej obojętny. Zwtaszcza ojciec traktowat mnie jak powietrze, ale mama też... Nigdy nic mi nie mówili ani $w$ ta, ani $w$ tamta stronę [G.G. - 36 lat, kawaler, mieszkaniec wsi, wykształcenie zawodowe recydywista jednokrotny, wyroki skazujące za kradzieże $\mathrm{z}$ włamaniem oraz oszustwo]

Mama? Ja nie znam mamy. Miatem 7 miesięcy jak ona od nas uciekta. Mój tata pracowat, a ja głównie u babci siedziatem. Pałętałem się gdzieś po podwórkach. Na Pradze mieszkatem, na Grochowie się wychowatem i na Szmulkach. Takie tereny patologiczne trochę. Jak to dzieciak, bujałem się po prostu, wszedtem w złe kręgi i siedzi się. Myśle, że wszystko byto dobrze, tylko że miałem zbyt dużo swobody. Zaczątem się zadawać z osobami, z którymi nie trzeba i jako dzieciak poszedtem do jednego zaktadu poprawczego, drugiego i tak to... Ale raczej miatem za dużo swobody po prostu. Nawet mój ojciec uważał, że babcia za dużo swobody mi dała i mi 
się w głowie poprzewracało. [D.B. — 36 lat, kawaler, mieszkaniec dużego miasta, wykształcenie podstawowe, recydywista trzykrotny, wyroki skazujące za kradzieże]

Kary raczej też nie byty stosowane, raczej byto, „a rób, co chcesz”. Jak byt jakiś pomyst kary, to ja po prostu wychodzitem, a im było obojętne, co ze sobq zrobie, gdzie i z kim pójdę. Traktowali mnie dzieciaka jak obcego człowieka. Jak dorostem, to trochę próbowali wptywać na moje wyskoki, ale ja ich już nie stuchatem [I.S. —36 lat, rozwiedziony, mieszkaniec wsi, wykształcenie średnie, recydywista dwukrotny, wyroki skazujące za kradzieże]

Najrzadziej wskazywana była postawa rodzicielska dyscyplinująca (postawa „zimna” - 12,1\%). Czynów przemocy fizycznej i psychicznej dopuszczali się najczęściej ojcowie mieszkający na wsi.

Ojciec byt surowy, a matka zawsze zapracowana, raczej nie mieli dla nas czasu. Jak coś przeskrobatem, to ojciec spuszczat lanie... Zwłaszcza gdy się dowiedziat, że bytem na wagarach, spuszczat mi taki łomot, że często nie wiedziatem, jak się nazywam... [T.O. — 33 lata, kawaler, mieszkaniec wsi, wykształcenie zawodowe, recydywista jednokrotny, wyroki skazujące za pobicie, oszustwo oraz usiłowanie gwałtu]

Mam ojca i młodszego brata. Moja mama nie żyje. Zginęła w wypadkuprzejechat ja samochód, jak wracala z pracy na rowerze... Miatem wtedy 19 lat. $W$ dzieciństwie, które chyba byto szczéśliwe, jeździliśmy razem na dziatke i na wakacje. Najbardziej kochatem i szanowatem matkę. Dbata o nas, dawata nam dużo ciepła, często przytulata... Matka zawsze mnie kryła, bo ojciec używat pasa. Bywato różnie, ale teraz moge powiedzieć, że go mocno nadużywat. [M.M. — 42 lata, żonaty, mieszkaniec małego miasta, wykształcenie podstawowe, recydywista trzykrotny - wyroki skazujące za kradzieże oraz rozbój z użyciem niebezpiecznego narzędzia]

U nas $w$ rodzinie nie było czegoś takiego jak bezstresowe wychowanie, stowa rodziców byty święte, nie można byto się im sprzeciwiać — inaczej dostawaliśmy straszne lanie. Mama lubiła stosować zakazy, ojciec często skórę ostro przetrzepat, jak się nie stuchaliśmy [R.K. — 49 lat, żonaty, mieszkaniec dużego miasta, wykształcenie zawodowe, recydywista jednokrotny, wyroki skazujące za kradzieże samochodów]

Zawsze liczyłem się ze zdaniem rodziców, a zwłaszcza ojca. Chciałem mu zaimponować, żeby byt ze mnie dumny, no wiesz, chciatem, żeby mnie zauważat... Ale on wolat mnie karcić, zawsze za spóźnienie albo jak robiłem coś złego... dostawatem pasem, albo kablem po nogach, bo tak, no przecież chlopak ma być twardy... [B.U. - 41 lat, wdowiec, mieszkaniec małego miasta, wykształcenie średnie, recydywista dwukrotny, wyroki skazujące za kradzieże oraz usiłowanie gwałtu] 
Trzy negatywne postawy rodzicielskie: „chwiejna” (niekonsekwentne oddziaływanie), „letnia” (obojętno-odrzucająca) oraz „zimna” (dyscyplinująca) owocują niewydolnością wychowawczą, bezradnością rodziców w sytuacjach związanych z niepowodzeniem szkolnym lub przynależnością dzieci do oddziałujących negatywnie nieformalnych grup rówieśniczych.

W rodzinie czworo nas byto. Ja nie pochodzę z rodziny patologicznej, chodziliśmy do kina, razem spędzaliśmy wakacje, działka u dziadków, no tak jak normalni wszyscy ludzie spędzaja ze soba czas... W dzieciństwie najbardziej kochatem ojca - tata dla mnie to autorytet. Rodzice chyba mnie kochali, jak bytem mały, a później trochę lipa - jak bytem starszy, to mieli jakieś pretensje. W szkole podstawowej to byty czasy trzepaków. Rzucało się scyzorykiem, rysowato się takie kótko, dzielito się, potem się cykało. Dzieciństwo to miatem wesote, a potem wszedtem $w$ grupę skinheadów, stuchaliśmy narodowe pieśni, ale teraz to sie pomieszało wszystko. Teraz punki chodza w takich sznurówkach jak skinheadzi. Ale nie, mi to już przeszło dawno. Zostało mi po tym to, że nauczyłem się kraść, oj przeszkolenie to od chłopaków dostałem niezłe. Chodziliśmy na włamy, a po skoku przy piwku śpiewaliśmy te pieśni narodowe (śmiech). Po szkole podstawowej poszedtem do zawodowej, bo chciałem zatożyć własny interes, otworzyć warsztat i myjnię samochodowa, ale potem rzucitem tę szkotę, bo się zakochatem i zamiast chodzić do szkoty, to chodzitem do kobiety, do niej spać tam. Czyli można powiedzieć, że mam podstawowe. Pierwszy rok tylko chodzitem, ale nie zdałem i już tę szkołę trochę olatem. [N.R. - 35 lat, rozwiedziony, mieszkaniec dużego miasta, wykształcenie podstawowe, recydywista trzykrotny, wyroki skazujące za kradzieże]

Moje dzieciństwo było smutne - rodzice nie zajmowali się mna, sam się soba zajmowatem. Należatem do grupy osiedlowej niekoniecznie dobrej, ale rodzice nie mieli na to wplywu, nie mieli nic do powiedzenia. Nie liczytem się z ich zdaniem, ale oni z moim też nie... Częściej bytem na wagarach niż w szkole. Chodzitem z ludźmi ze szkoty, z osiedla. No i przez to większość mojego życia spędzitem w ośrodkach wychowawczych. [A.Z.22 lata, kawaler, mieszkaniec średniego miasta, wykształcenie gimnazjalne, recydywista jednokrotny, wyroki skazujące za wymuszenia i udział w grupie przestępczej oraz rozprowadzanie narkotyków]

Między postawami wychowawczymi rodziców a umiejscowieniem kontroli u badanych recydywistów nie wykryto istotnej statystycznie zależności [Nowak 2017b]. Zauważalne są jednak niewielkie różnice w odniesieniu do typu postaw rodzicielskich — rodzice większego odsetka badanych recydywistów posiadających LOC zewnętrzny wykazywali częściej postawę „letnią” (obojętno-odrzucającą) oraz „chwiejną” (oddziaływanie niekonsekwentne) niż postawę „gorącą” (kochająco-wyrozumiałą) czy „zimną” (karząco-dyscyplinującą). 
Należy podkreślić, że skutkiem postaw rodzicielskich obojętno-odrzucających i niekonsekwentnego oddziaływania jest u dzieci poczucie osamotnienia, krzywdy i niesprawiedliwości, co sprawia, że częściej niż dzieci doświadczające innego typu postaw rodzicielskich są wycofane i nieradzące sobie z trudnościami, często niedostosowane społecznie i popełniające czyny przestępcze. Wynik badania wskazuje na znaczącą rolę negatywnych postaw rodzicielskich także w rozwoju myślenia przestępczego u dzieci. W dorosłości prowadzą one przestępczy styl życia będący kontynuacją wcześniejszych zachowań ryzykownych - próby zwrócenia na siebie uwagi rodziców, identyfikacji z negatywną grupą rówieśniczą czy alkoholowo-narkotykowej ucieczki przed problemami.

Opisując swoje funkcjonowanie w rodzinach pochodzenia, ponad połowa badanych recydywistów postrzegała swoje relacje z rodzicami (zwłaszcza $\mathrm{z}$ matkami) jako dobre lub bardzo dobre, podobnie jak i kontynuację tych relacji w dorosłości [Nowak 2017b]. Z analizy danych źródłowych wynika jednak, że często były one nie tylko wspierające, podbudowane miłością i owocujące wzajemnym szacunkiem, ale także pełne napięć. Okazało się także, że osadzeni w zakładzie karnym typu półotwartego częściej utrzymują dobre i bardzo dobre relacje $\mathrm{z}$ rodzicami. Wynika to prawdopodobnie $\mathrm{z}$ faktu, że $\mathrm{w}$ porównaniu z osobami osadzonymi w zakładzie zamkniętym mają oni wiele okazji do ich podtrzymywania w trakcie stosunkowo częstych przepustek i są także częściej odwiedzani przez członków swoich rodzin. Częste kontakty skazanych $\mathrm{z}$ rodzinami, dobre relacje z członkami rodziny własnej oraz osobami z szerszych kręgów rodzinnych sprzyjają stabilizacji więzi wewnątrzrodzinnych sprzed uwięzienia. Wspomagają również oddziaływania resocjalizacyjne i dają osadzonym nadzieję na zmianę ich dotychczasowego, kryminalnego statusu po zakończeniu odbywania kary pozbawienia wolności.

Najbardziej związany bytem z ojcem. Obaj opiekowaliśmy się mama, bo pracowata na trzy zmiany i moimi młodszymi braćmi. Trzech ich mam $i$ wtedy czutem sie za nich odpowiedzialny. Pamiętam, jak pewnego razu ojciec mnie sprat na kwaśne jabłko, bo mój najmłodszy brat spadt z drzewa. Bytem na niego wściekty i później wyżytem się na bracie, ale dopiero jak wyzdrowiat. Troszeczkę go poturbowatem. Nic mu nie byto, ale musiałem mu przypomnieć, żeby się pilnowat. Rodziców ciagle $w$ domu nie byto i wszystko byto na mojej głowie. Bardzo wcześnie dorostem, bo musiałem. Liczytem się ze zdaniem rodziców, bo ich stowa byty święte, nie można byto się im sprzeciwiać, inaczej dostawaliśmy lanie. Nie mogłem się sprzeciwiać i czasem musiałem siedzieć cicho, a to wkurzało mnie trochę. Jednak zawsze mogłem iść do nich z jakimś problemem, mogłem na nich liczyć. Ojciec zmart kilka lat temu, a z mama utrzymuję kontakt. Jak jestem na wolności, to staram się, by jej niczego nie zabrakło. Spędzamy też razem wszystkie święta. [Z.T. - 39 lat, żonaty, mieszkaniec miasta średniej wielkości, wykształcenie średnie, recydywista jednokrotny, wyroki skazujące za oszustwa] 
Z mama dużo rozmawialiśmy, zawsze miała czas dla mnie. Czułem, że mnie kocha, chce ochronić przed ztem. Ja ja bardzo szanowatem i nadal szanuje. Ojciec byt pracowity. Byt alkoholikiem, ale to byt świetny fachowiec. Zawsze to co miat zrobić - robit. Z nami, czyli z dziećmi, nie miat dobrego kontaktu... chyba nie umiat się z nami porozumieć, ale kochat nas, teraz to widzę. No i dziadek. Tak, dziadek byt najlepszy! Zawsze wrażenie na mnie robit. Tym co robit, jak mówit... ech! tak, fajny byt... Mama teraz mieszka u siostry, ale się tyle porobiło... widzimy się od święta do święta... wiesz, teraz tutaj jestem, ona już schorowana, no i odległość mieszka $500 \mathrm{~km}$ stad. [A.Ł. — 42 lat, rozwiedziony, mieszkaniec wsi, wykształcenie podstawowe, recydywista trzykrotny, wyroki skazujące za kradzieże, kradzież z włamaniem, rozbój i niewywiązywanie się z obowiązku alimentacyjnego]

Relacje złe, pełne toksycznych akcentów albo zostały zerwane, albo trwają nadal i są sporadyczne, z pogłębiającą się wzajemną niechęcią [Nowak 2017b]. W tym zakresie analiz badawczych odnotowano zależność istotną statystycznie, wskazującą, że im wyższy poziom wykształcenia posiada osoba skazana, tym jej relacje z rodzicami są gorsze. Należy przy tym pamiętać, że rodzice badanych recydywistów posiadali najczęściej niski poziom wykształcenia (podstawowy i zawodowy), co mogło mieć pośredni wpływ na zaburzenia relacyjne i komunikacyjne między nimi i ich bardziej wykształconymi dziećmi, lepiej rozumiejącymi rzeczywistość. Lub odwrotnie - wyżej wykształceni rodzice nie potrafią porozumieć się z dziećmi zapóźnionymi edukacyjnie, z którymi jeszcze $\mathrm{w}$ dzieciństwie nie potrafili się porozumieć. Inną próbą wyjaśnienia tej zależności mogą być ułomności osobowościowe i ograniczenia poznawcze, niedostatki socjalizacyjne i kulturowe rodziców oraz miejsce ich zamieszkania. Wynik badania może stanowić zatem punkt wyjścia pogłębienia omawianego zagadnienia i wyjaśnienia odnotowanej zależności w sposób bardziej zobiektywizowany.

Praktycznie nigdy nie liczytem się ze zdaniem rodziców. W domu pomagatem, ale to bardziej z przekonania, że trzeba pomóc. Bo za bogato nie było, byto tylko co jeść. Ojciec na gospodarce gospodarzyt, ale nie rozwijat się, stat $w$ miejscu, no i ja praktycznie od 15 roku życia daję sobie radę sam, a $w$ zasadzie od tego czasu nie mieszkatem $w$ domu. Nigdy nie dostałem od rodziców nawet złotówki na dyskotekę. Ubranie to już od dziecka musiatem sobie kupić sam, coś ukraść, coś sobie kupić, bo po prostu, jak oni coś kupili, to takie, że człowiek się wstydzit chodzić [...] Zawsze bytem buntownikiem. $Z$ rodzicami sie nie rozmawiało, bo caty czas pracowali na roli. Ja bytem najstarszy z rodzeństwa, więc musiatem się pozostatymi zajmować, albo w gospodarstwie pomagać, ale w oczach rodziców to ja bytem najgorszy. Teraz z ojcem czasami pogadam, ale niechętnie, bo on chla. Jak to na wsi [A.Ł. — 36 lat, żonaty, mieszkaniec wsi, wykształcenie średnie, dwukrotny recydywista, wyroki skazujące za pobicia] 
Mama miała tyle swoich problemów, że mnie nie ogarniała. I w pewnym momencie wyszła z założenia, że jak się przejadę parę razy w życiu $i$ oberwę, to może coś zrozumiem. Po prostu była strasznie liberalna, np. jeśli chodzi o marihuane, to do dziś nie ma pretensji o to, że palitem skręty na wolności - jej to nie przeszkadzało. No i ogólnie, nie wiedziała, jak przekazać mi swoja wiedzę. Bo często ja z niq zaczynałem jakieś tematy, bardziej się otwierałem przed niq niż ona przede mna. Nie mogtem mieć do niej pretensji. Po prostu kobieta zapracowana, za dużo problemów na głowie... Ojciec z kolei zawsze tłumaczyt mi, że praca jest najważniejsza, caty czas praca, praca, praca... Podsuwat mi pomysty, żeby zrobić papiery np. na dźwigi, żeby pracować na budowach, żeby na spawacza wyjechać do Niemiec, węzty robić gazowe. Próbowat wskazywać mi, co jest dobre, co da mi przyszłość, ale w sumie mu się to nie udato. Ojciec to byt „,cienias" przez samego siebie, a teraz caty czas chla. Od dwu lat jest totalnie zapity. Ojciec z matka chcieli się rozwieść, ale podziat majątku sprawiat problem. Nie żyja $w$ dobrych relacjach ogólnie, zreszta ja z nimi też nie. Ojciec mnie nie odwiedza, a ja nie piszę do niego. Czasem próbuję się do niego dodzwonić, ale ciagle jest zachlany i nie potrafi obstużý telefonu. Zagubit się strasznie... [M.J. - 31 lat, kawaler, mieszkaniec wsi, wykształcenie podstawowe, recydywista dwukrotny — wyroki skazujące za usiłowanie zabójstwa, kradzieże i kradzież z włamaniem]

Generalnie na śmierć mnie zagadywali, wszystko miałem tlumaczone czasami wolatbym dostać w skórę, niz ich stuchać caty dzień. Do dzisiaj mama mi caty czas coś tlumaczy, caty czas mnie uważa za swojego ucznia. Chyba jej jedyne niepowodzenie w nauczycielstwie to ja. [T.R. - 51 lat, wdowiec, mieszkaniec małego miasta, wykształcenie zawodowe, recydywista jednokrotny, wyroki skazujące za pobicie, kradzież oraz rozbój z użyciem niebezpiecznego narzędzia]

Konkludując, należy podkreślić, że rodzina pełni określone funkcje instytucjonalne, odpowiedzialne za: zaspokojenie potrzeb seksualno-prokreacyjnych; wspólnotę ekonomiczną; poczucie bezpieczeństwa; dostosowanie młodego pokolenia do życia społecznego i kultury danego społeczeństwa [Bojkało, Koperek 2013, s. 64]. Jest miejscem przekazu wzorów i postaw, poglądów i opinii. To właśnie w rodzinie człowiek przyswaja normy, wartości, zasady i reguły postępowania społecznego oraz zaspokaja swoje potrzeby podmiotowe i ponadpodmiotowe. $\mathrm{W}$ dużym uproszczeniu właśnie tak należy postrzegać znaczenie rodziny i jej rolę w rozwoju człowieka.

Prezentowane wyniki badania wskazują jednak, że większość badanych recydywistów pochodzi z rodzin polidysfunkcyjnych, naznaczonych obecnością czynnika patologicznego, którym jest najczęściej alkoholizm obojga lub jednego z rodziców, przemoc i przestępczość. Były to rodziny biedne, często zaniedbane kulturowo, borykające się z wieloma problemami, których słabo wykształceni 
i nieporadni życiowo rodzice nie umieli rozwiązać. Pracowali ciężko, by utrzymać rodzinę. Byli zmęczeni i odczuwali permanentny brak czasu na budowanie dobrych relacji z dziećmi. Jedni pracowali etatowo lub wieloetatowo, inni podejmowali najczęściej prace dorywcze lub sezonowe. Często stosowali sztywne, nieskuteczne sposoby radzenia sobie, w tym strategie ucieczkowe prowadzące ich najczęściej w otchłań alkoholizmu. Wszystko to skutkowało zaburzeniami relacyjnymi i komunikacyjnymi, niekorzystnymi postawami rodzicielskimi i zaburzeniami rozwojowymi dzieci, powolnym rozpadem rodziny i rozwodem, nowymi związkami oraz zwykle toksycznymi relacjami i konfliktami ojczymów i macoch z dziećmi.

\subsubsection{Rodzina własna: przeszłość i teraźniejszość}

W perspektywie psychologicznej rodzina postrzegana jest jako system wzajemnych powiązań, w którym układ relacji wyznacza jej wspólnotowość. Inaczej traktują rodzinę socjolodzy, którzy podkreślają jej kluczowy udział w procesie socjalizacji, rozpatrując ją przez pryzmat ról pełnionych przez członków rodziny i pozycji zajmowanych przez nich w systemie rodzinnym. $Z$ kolei w perspektywie pedagogicznej rodzina jest miejscem formowania się młodego pokolenia, stanowiąc podstawowe i naturalne środowisko społeczno-wychowawcze. Niezależnie jednak od przyjętego paradygmatu, dla każdego człowieka rodzina stanowi podstawową wartość egzystencjalną. Jest specyficznym i unikatowym środowiskiem życia, w ramach którego dokonują się procesy opieki, wychowania, socjalizacji oraz edukacji dzieci i młodzieży [Nowak, Banasiak, Górnicka, Zajęcka 2019].

Rodzina funkcjonuje prawidłowo, gdy zaspokajane są indywidualne i wspólne potrzeby wszystkich jej członków oraz gdy utrzymuje ona silne więzi łączące ją ze środowiskiem. W takiej rodzinie dziecko buduje swoje „Ja”, zaspokaja swoje potrzeby emocjonalne, harmonijnie wzrasta i prawidłowo się socjalizuje. Z kolei rodziny $\mathrm{w}$ różnym stopniu niewypełniające swoich podstawowych funkcji charakteryzuje tendencja do przyjmowania przez członków rodziny niefunkcjonalnych ról rodzinnych, niski poziom adaptacyjności i wzajemnego zrozumienia, wysoki poziom dezintegracji, silne poczucie trudności rozwojowych oraz upośledzenia funkcjonalnego. Rodziny dysfunkcyjne stanowią czynnik ryzyka dla wychowujących się w nich dzieci, które w wielu przypadkach wykazują zaburzenia rozwojowe, w tym poznawcze i socjalizacyjne [Nowak 2011]: Należy przy tym pamiętać, że zakres powinności oraz warunki progowe dysfunkcjonalności rodziny wyznaczane są jej społecznym postrzeganiem jako systemu funkcjonującego w sprzężeniu zwrotnym z otoczeniem bio-socjo-kulturowym.

\section{Zaburzenia funkcjonalne i strukturalne systemów rodzinnych}

Przez fakt zaistnienia problemu penitencjarnego, rodziny osób skazanych na karę pozbawienia wolności doświadczają głębokiego kryzysu. Badania własne pozwoliły ustalić, iż większość rodzin własnych badanych recydywistów, 
to rodziny polidysfunkcyjne, wieloproblemowe, posiadające spektrum cech ukształtowanych wskutek rozchwiania równowagi systemowej oraz kumulacji nierozwiązanych problemów. Rodziny te realizują najczęściej dewiacyjny model życia rodzinnego [de Tchorzewski 2005], którego wyznacznikami są zaburzenia występujące w obrębie niemal wszystkich założonych funkcji rodziny, zagrażające jej kondycji i trwałości oraz wpływające negatywnie na rozwój wychowywanych w nich dzieci. Dla tego typu rodzin charakterystyczna jest niewydolność wychowawcza rodziców wynikająca albo z nadmiaru tolerancji, bardzo słabej kontroli dziecięcych zachowań oraz braku autorytetu, albo z nadmiaru kontroli i stosowania wobec dzieci zbyt silnych sankcji dyscyplinujących, nieadekwatnych do przewinienia. Dzieci wychowywane w rodzinach polidysfunkcyjnych (zwłaszcza adolescenci) podejmują samodzielne, często chaotyczne i sprzeczne z oczekiwaniami społecznymi próby konstruowania własnego świata iluzorycznych wartości, moralności, obyczajów i norm. Dominacja zakazów, nakazów, ostra dyscyplina oraz bezzasadne wygaszanie pragnień dziecka wskazujące na istnienie w systemie rodzinnym granic uwikłanych, może skutkować jego wrogim nastawieniem do otoczenia w okresie dojrzewania i wczesnej dorosłości lub skłonnością do popełniania przestępstw [Nowak 2019b]. Wiąże się to z dynamiką i zakresem zmian zachodzących w obrębie granic wewnętrznych rodziny, które - jeżeli są negatywne lub mają zabarwienie silnie traumatyzujące mogą skutkować napięciami emocjonalnymi i konfliktami wewnątrzrodzinnymi [Goldscheider, Goldscheider 1989, s. 87-97].

Rodziny polidysfunkcyjne są dotknięte zazwyczaj traumą nierówności społecznej lub są w pełni traumatyczne, z nikłą siecią więzi osobowych i całkowitym lub częściowym brakiem dóbr materialnych i/lub możliwości ich osiągania. Dorośli członkowie tego typu rodzin nie stanowią autorytetu dla wychowujących się w nich dzieci, które nie odczuwają potrzeby zdobywania wykształcenia. Rodziny polidysfunkcyjne dotknięte syndromem wyuczonej bezradności charakteryzuje dominacja sił odśrodkowych i równocześnie tendencja do zamykania granic zewnętrznych, blokująca wymianę informacji z otoczeniem społecznym [Seligman 1975]. Rodziny tego typu wykazują cechy sztywności adaptacyjnej. Uporczywie trzymają się nawyków i nie przejawiają gotowości do przyjęcia pomocy i wsparcia społecznego, czego efektem jest wejście całej rodziny na ścieżkę chaosu życiowego, permanentnego poczucia niemożności i bezradności. Badania Ronalda Adlera, Lawrence'a Rosenfelda, Russela Proctora [2006] wykazały, że deficyty umiejętności komunikacyjnych i perswazyjnych są hamulcem dążeń do osiągania zamierzonych celów (aspiracji życiowych, edukacyjnych, zawodowych) i w poważnym stopniu mogą ograniczać efektywne wywiązywanie się z obowiązków narzucanych jednostce w toku życia rodzinnego i społecznego.

Badania empiryczne nad rodzinami w kryzysie wyraźnie wskazują, że tkwiące w głębokim kryzysie rodziny wieloproblemowe charakteryzuje spektrum niekorzystnych cech, do których zaliczyć można między innymi [Nowak 2011]: 
- niewydolność ekonomiczną powiązaną z niskim poziomem wykształcenia, brakiem kwalifikacji zawodowych i bezrobociem;

- zaburzone relacje z rodziną pochodzenia, brak pomocy i wsparcia społecznego;

- trudne warunki materialne i mieszkaniowe;

- obecność czynników patologizujących (przestępczość, przemoc, uzależnienia $\mathrm{i}$ in.);

- bezradność prowadząca do lęku społecznego, obniżenia poczucia sprawstwa, stosowania nieadekwatnych strategii zaradczych oraz utraty tożsamości grupowej;

- niska dojrzałość społeczno-emocjonalna oraz niewydolność wychowawcza rodziców;

- niespójność między uznawanymi normami i wartościami a możliwością ich realizacji.

Powyższe cechy posiadają także rodziny własne badanych recydywistów, których podstawowym wyznacznikiem jest wielokrotna i często długotrwała izolacja więzienna jednej z osób strategicznych dla funkcjonowania rodziny partnera/ojca. Analiza narracji recydywistów w odniesieniu do rodzin pochodzenia i zestawienie $z$ opisami funkcjonowania ich własnych rodzin pozwala na postawienie tezy o międzypokoleniowym przekazywaniu polidysfunkcji systemowej. Źródła polidysfunkcji są jednak różne i wieloczynnikowo uwarunkowane. Pogłębiona analiza danych umożliwiła wyłonienie głównych źródeł polidysfunkcji obecnych w rodzinach pochodzenia i kontynuowanych w rodzinach własnych badanych recydywistów lub też pojawiających się nowych, patologizujących źródeł, będących konsekwencją traumatycznych doświadczeń wyniesionych z dzieciństwa. Dzieci wychowujące się w rodzinach polidysfunkcyjnych są wyalienowane i wykazują najmniejszy stopień zewnętrznej ekspresji.

Wyniki badań Mariana Jędrzejczaka i Iwony Boroń [2003] wskazują, że młodzież biorąca narkotyki pochodzi najczęściej z rodzin patologicznych, naznaczonych brakiem więzi i ciepła rodzinnego. Obecność czynnika patalogizującego, bieda i bezrobocie oraz zaburzony proces socjalizacji pierwotnej, to najczęstsze czynniki ryzyka zażywania narkotyków przez dzieci i młodzież. Wyniki badań nad rodzinami w kryzysie wykazały ponadto, że symptomy niedostosowania społecznego dzieci (w tym nadużywanie alkoholu i zażywanie narkotyków) występują częściej w tych rodzinach, w których co najmniej jedna osoba dorosła zamieszana jest $\mathrm{w}$ konflikt $\mathrm{z}$ prawem, w porównaniu $\mathrm{z}$ rodzinami, w których ten problem nie występuje [Nowak 2011].

Prezentowane w niniejszym opracowaniu badania wykazały, że rodziny z problemem penitencjarnym są często naznaczone głęboką dysfunkcją wygenerowaną przez chorobę alkoholową jednego lub obojga rodziców. W tego typu systemach rodzinnych powstaje luka w zakresie roli przywódczej, gdyż uzależniony rodzic (zazwyczaj ojciec) przestaje ją odgrywać. Konsekwencją jest wzrost poziomu chaotyczności systemowej, rozumianej jako brak stałych reguł i norm, a mechanizmy patologiczne uaktywniają się we wszystkich wymiarach życia rodzinnego [Margasiński 1996, 2010; Szczepańska 1992]. Obecność w rodzinie 
zjawiska patologicznego (m.in. przestępczości, alkoholizmu, narkomanii, przemocy) lub patologii krzyżowych sprawia, że rodzina funkcjonuje na podstawie wzorców zachowań, norm i wartości nieakceptowanych społecznie, zaś wychowujące się w niej dzieci uwewnętrzniają wadliwe postawy i zachowania prezentowane przez pozostałych członków rodziny. W dorosłości dzieci te budują własne, dysfunkcyjne lub polidysfunkcyjne, gniazda rodzinne. Przenoszenie urazu doświadczonego w dzieciństwie na okres dorosłości [Herman 1998] generuje trudności w relacjach interpersonalnych, problemy z nawiązaniem i utrzymaniem bliskości emocjonalnej z innymi ludźmi. Konsekwencją dysfunkcji socjalizacyjnej rodziny jest depersonalizacja dziecka; utrata przez nie tożsamości skutkująca demoralizacją i alienacją społeczną, a w dorosłości — zaburzeniami emocjonalnymi i zachowaniami ryzykownymi [Nowak 2019b].

Do znaczących czynników ryzyka zachowań problemowych/ryzykownych dzieci i młodzieży należą [Mazur, Tabak, Małkowska-Szkutnik i in. 2006]:

a) czynniki indywidualne: temperament (impulsywność, nadpobudliwość agresywność); wczesne zachowania problemowe (agresywne, buntownicze, niepodporządkowywanie się dorosłym, wczesna inicjacja alkoholowa); duże zapotrzebowanie na stymulację (potrzeba wrażeń, poszukiwanie stymulacji); deficyty poznawcze (niski poziom inteligencji);

b) związane z sytuacją rodziny i funkcjonowaniem psychospołecznym rodziców: niski status socjoekonomiczny rodziny (niskie dochody, niski poziom edukacji rodziców, brak stałej pracy); alkoholizm lub inne uzależnienia rodziców, zwiększające biologiczną podatność dziecka na rozwój uzależnienia, dostarczające negatywnych wzorów i pogarszające poziom opieki; choroby psychiczne rodziców (depresja u matki); chroniczne konflikty rodzinne z udziałem dziecka (rozwód lub separacja rodziców, wrogość między rodzicami, agresja, nadmierny krytycyzm); negatywne wzory starszego rodzeństwa (picie, palenie, używanie narkotyków); doświadczenia traumatyczne (przemoc $\mathrm{w}$ rodzinie);

c) związane z realizacją ról rodzicielskich: niekorzystne czynniki prenatalne (m.in. palenie papierosów lub picie alkoholu przez matkę w czasie ciąży); zakłócenia w rozwoju relacji rodzic-dziecko (wrogość wobec dziecka, emocjonalne odrzucenie, trudności w porozumiewaniu się); nieprawidłowa realizacja ról rodzicielskich (niespójne i niekonsekwentne postępowanie, kary cielesne, brak granic w okresie dorastania, zaniedbywanie);

d) związane ze szkołą: niepowodzenie w nauce; negatywny stosunek do szkoły i obowiązków szkolnych oraz problemy z zachowaniem;

e) związane $\mathbf{z}$ rówieśnikami: naśladowanie zachowań problemowych (picie, palenie, używanie narkotyków, wykroczenia, gangi dziecięce lub młodzieżowe); aprobata rówieśników dla zachowań problemowych; odrzucenie przez rówieśników;

f) związane $\mathbf{z}$ miejscem zamieszkania (lokalną społecznością): wysoka dostępność substancji psychoaktywnych; wysoki poziom zagrożenia ładu społecznego (przestępczość, przemoc, nieprzestrzeganie prawa); niekorzystne 
warunki ekonomiczne rodziny związane $\mathrm{z}$ miejscem zamieszkania (bieda, brak pracy);

g) związane z dzialalnością mediów i wpływami popkultury: ekspozycja na negatywne przekazy medialne.

Znajomość czynników ryzyka oraz czynników chroniących umożliwia zdiagnozowanie aktualnego i potencjalnego stanu jednostki oraz zaprojektowanie racjonalnej działalności prewencyjnej, związanej z osłabianiem czynników ryzyka, a wzmacnianiem czynników chroniących [Wojcieszek 2013].

Wyniki prezentowanych badań własnych wskazują na udział niemal wszystkich wyżej wymienionych czynników ryzyka w rozwoju kariery przestępczej badanych recydywistów, w tym rodzinnych praźródeł przestępczości i uzależnienia od alkoholu. Powielanie rodzinnej polidysfunkcji i/lub patologii przewija się niemal w każdej narracji, a obraz relacjonowanego przez badanych recydywistów życia rodzinnego jest naznaczony dziecięcym smutkiem i cierpieniem. To obraz rodzin poranionych, rozbitych, alkoholiczych, niewydolnych wychowawczo, dotkniętych piętnem przestępczości, tkwiących w głębokim kryzysie wieloproblemowym. I takie też są ich rodziny własne.

Jestem jedynakiem trochę rozpieszczonym przez mamę. Tatę widywałem rzadko. Przez dlugi czas wujek mnie wychowywat. Mama zaczęla pić, gdy tatę zastrzelili... Jakieś gangowe porachunki mieli. No i wujek $i$ babcia mnie wychowywali przez kilka ładnych lat. Dopilnowali, bym się wyksztatcit - jestem po technikum [...] Do czasu matzeństwa mieszkatem z rodzina poza Warszawa. Teraz mieszkam w stolicy, mam dwoje dzieci i żonę. Córka ma 9 lat $i$ jest $z$ pierwszego matżeństwa, a $z$ drugiego matżeństwa mam syna - 2 lata i 8 miesięcy. Córka bardzo za mna tęskni, a syn się urodzit teraz. Jak poszedtem do więzienia w styczniu 2013, to żona już byta w zaawansowanej ciaży. Syn mi się w kwietniu urodzit. Skazany to jestem ogólnie 12 raz. Teraz zostało mi jeszcze 2 lata odsiadki. Żona czasem mnie odwiedza, a syna kolega mi przywozi na widzenia. Przez pobyt w więzieniu rozluźnity się moje więzi z żona. Nie wiem, jakie sa problemy w rodzinie, bo nie widzę tego na co dzień, nie mogę w jakikolwiek sposób jej wesprzeć. No cóż..., żona dała mi ostatnia szansę - wyjdę stąd i już nie wróce [...] mam warsztat samochodowy, który otworzytem z pieniędzy wiadomo jakich, ale teraz musze za to odpowiedzieć. Zanim mnie zamknęli, to miałem już przygotowane umowy z firma taksówkowa, żeby u mnie samochody naprawiali. [E.D. - 49 lat, żonaty, mieszkaniec dużego miasta, wykształcenie średnie techniczne, jedenastokrotny recydywista, wyroki skazujące za wymuszenia, dwa napady z bronią palną, wyłudzenia kredytów, bójka z policją, groźby i posiadanie broni].

Gdy byłem dzieckiem, to mojej rodzinie ogólnie nic nie brakowało. Ojciec pracowat na budowach, jeździt też za granice zarabiać. A matka była kucharka w szkole. Ojciec jak wracat do Polski, to kasę przywozit. Ale jak 
tylko dtugo na tyłku siedziat, to zaczynat popijać. On tak chyba z nudów pit. Kłócili się, bo matka nerwowa była. Ale żeby jakoś strasznie, to nie. Może $z$ raz ojciec matkę uderzyt [...] Ja mam żonę $i$ dwóch synów - 11 i 8 lat. Relacje mam z nimi raczej chłodne, bo żona mieszka osobno, a dzieciaki widuje sporadycznie. Sytuację mojej rodziny nazwatbym trudna. Żona nie pracuje. Ma zasitek dla bezrobotnych, a mnie o alimenty męczy. Właśnie $z$ tego powodu tutaj jestem. [W.R. - 41 lat, żonaty, mieszkaniec miasta średniej wielkości, wykształcenie zawodowe, dwukrotny recydywista, wyroki skazujące za kradzież, kradzież z pobiciem, niepłacenie alimentów]

$\mathrm{Na}$ jakość życia całej rodziny wpływają w znaczącym stopniu relacje wewnątrzrodzinne, zwłaszcza między partnerami. Utrata satysfakcji ze wspólnego życia, ustanie emocjonalnej wymiany, obojętność wobec partnera i niezaspokajanie jego potrzeb oraz brak otwartości, generują przewlekły stres i prowadzą do destrukcji systemu rodzinnego. Uwarunkowania i mechanizmy procesów dezintegracyjnych prowadzących partnerów do podjęcia decyzji o separacji czy rozwodzie nie są jeszcze do końca zbadane, ale wiedza psychologiczna w tym zakresie ciągle się powiększa. Wiadomo jednak, że partnerzy w każdym wieku i w każdym stadium życia rodzinnego są potencjalnie narażeni na rozwód i perturbacje z nim związane, dotyczące głównie opieki nad dziećmi, spraw finansowych, alimentacyjnych czy spadkowych. Rozwód postrzegany jest jako proces dynamiczny o charakterze rozwojowym, potencjalnie skutkujący zmianą struktury rodziny i wzorów interakcji [Anderson, Sabatelli 1999].

Wielu badaczy uważa, że rozwód i jego następstwa mają charakter patogenny. Coraz częściej teza ta nie jest w pełni akceptowana, gdyż inni psycholodzy dostrzegają, że w przebiegu cykli rozwojowych rodziny rozwód jest sytuacją kryzysową, która prowadzić może do porażki, ale też skutkować może rodzinnym sukcesem. Jest to zależne od organizacji i jakości życia obojga partnerów po rozwodzie.

Pierwszym symptomem dezintegracji związku jest kryzys relacji i bolesne doświadczenia emocjonalne (konflikty, gniew, żal, złość i wzajemna wrogość). Ten etap jest jednak najtrudniejszy dla dzieci, które obserwują i mocno przeżywają starcia między rodzicami, walkę o ich uwagę i próbę przeciągnięcia na swoją stronę. Sprawia to, że u dzieci pojawiają się stany depresyjne, problemy w szkole czy zachowania ryzykowne. Kolejne etapy ścieżki rozwodowej są dla wszystkich członków rodziny okresami destabilizacji emocjonalnej, niepewności i rozedrgania uczuciowego. Młodsze dzieci nie rozumieją motywów postępowania rodziców i zagmatwania sytuacji rodzinnej. Mają poczucie winy i własnej odpowiedzialności za problemy doświadczane przez rodziców. Niektóre dzieci mogą jednak mieć poczucie wewnętrznej siły i żywić przekonanie, że są w stanie odwrócić proces rozpadu rodziny [Lauer, Lauer 1991].

Badania własne wykazały, że rozwód rodziców odcisnął silne piętno na psychice badanych recydywistów. Zdekompletowanie rodziny oraz nieudane próby ułożenia sobie życia przez wychowującego rodzica generowały różnorakie 
zawirowania $\mathrm{w}$ ich dalszym życiu, spychając ich nieuchronnie na drogę niedostosowania społecznego i przestępczości. Pomimo traumatycznych doświadczeń wynikających z rozwodu rodziców, w wielu przypadkach badani recydywiści powielali w dorosłości wzorzec rodziny rozbitej.

Poza mna w rodzinie sa jeszcze dwie siostry, jedna ma 21, a druga 27 lat. Ja nie miałem nigdy czasu wolnego, bo pracowatem w polu. Gdy miałem 12 lat, moi rodzice po raz pierwszy się rozeszli, potem wrócili do siebie $i$ znowu się rozeszli. Praktycznie caty czas bytem tylko z ojcem i z nim bytem zwiąany. Z matka nie miatem dobrego kontaktu. Liczytem się zawsze ze zdaniem ojca, z matki już nie, szczególnie jak po pierwszym rozstaniu wróciła do nas. Mama bardziej mnie zbywała, nie zajmowała się mna zbytnio, równie dobrze mogłoby mnie nie być. Rodzice rozeszli się 23 lata temu, a teraz mam macochę - dobra z niej kobiecina jest [...] Od zawsze podobatem się kobietom (śmiech). Gdy miatem 18 lat dwie koleżanki naraz zaszły ze mna w ciązę, i tak to moje powodzenie wyszło mi trochę bokiem. Teraz jestem już po rozwodzie. Mam troje dzieci. Z jednego zwiazku urodzit się syn, a z drugiego córka. Później, jak to wiadomo, z jedna z nich musiałem się ożenić. Zrobiłem to z ta dziewczyna, z która miatem córkę. Dwa lata po ślubie doczekaliśmy się też syna. Nie mam raczej wptywu na jego wychowywanie, bo po rozwodzie bardzo mato się z nim kontaktowatem, mimo że mieszka cztery kilometry ode mnie. Byta żona zreszta też nie zabiega o jakikolwiek kontakt. Ona nie pracuje, utrzymuje się z alimentów. [P.R. - 26 lat, rozwiedziony, mieszkaniec wsi, wykształcenie średnie techniczne, jednokrotny recydywista, wyroki skazujące za prowadzenie samochodu pod wpływem alkoholu]

Negatywne doświadczenia relacji między rodzicami wyniesione z rodziny generacyjnej badani recydywiści przenieśli do rodzin własnych. Ich związki okazywały się powierzchowne, gdyż w wielu przypadkach, w rodzinie pochodzenia nie mieli możliwości zaobserwowania, w jaki sposób można odgrywać małżeńską rolę. Wychowywani przez rozwiedzionych rodziców utracili sposobność do przejęcia męskiego wzorca funkcjonowania w związku. Większość z nich miała problemy z dostosowaniem się do rozwodu i akceptacją nowej struktury rodziny, zwłaszcza gdy wkrótce po rozwodzie pojawiał się w niej nowy partner matki lub partnerka ojca. Relacje z ojczymem lub macochą były najczęściej chłodne i pełne emocjonalnych napięć. Tylko sporadycznie pojawiały się opisy atencji dzieci wobec osób zastępujących im jednego z rodziców biologicznych. W wielu rodzinach dochodziło do rywalizacji między konkubentem matki a jej synem. Prowadziło to do zadrażnień na tyle silnych, że u dziecka pojawiały się symptomy niedostosowania społecznego, najczęściej w postaci notorycznego wagarowania i niepowodzenia szkolnego, ucieczek $\mathrm{z}$ domu, wejścia w negatywną grupę rówieśniczą i powielania promowanych przez nią zachowań ryzykownych, w tym czynów przestępczych. 
Jak podkreśla P.R. Amato [1993], brak kontaktu lub kontakt sporadyczny dziecka z rodzicem lub rodzicami zaburza jego prawidłowy rozwój. Destruktywne są przede wszystkim przeszkody stawiane dzieciom przez jednego z rodziców i jego działania prowadzące do odseparowania ich od rodzica, który nie sprawuje już nad nimi opieki rodzicielskiej. W ten sposób nakręcana jest generacyjna spirala niedostosowania społecznego dzieci i młodzieży oraz niesprawności wychowawczej rodziców.

$\mathrm{Z}$ racji pobytu $\mathrm{w}$ warunkach izolacji, a sprzed uwięzienia, także z powodu nadużywania alkoholu, skłonności do przemocy i braku kompetencji wychowawczych wielu recydywistów ma w znacznym bądź całkowitym stopniu utrudniony kontakt z własnymi dziećmi.

Mam przyrodniego brata i siostre, ale ja przyjątem nazwisko po swojej mamie, z która mieszkam, a z ojcem utrzymuję kontakt. Jak bytem maty, to ojciec nie mieszkał z mama, bo się z nim rozstała. $W$ dzieciństwie przeszedtem poważna chorobę - miatem usuwany nowotwór. Do lekarzy jeździtem z mama i tylko ona mnie odwiedzata, gdy musiałem zostać w szpitalu, bo ojciec powiedziat, że do szpitali to on jeździć nie będzie, więc jeździłem $z$ matka do Warszawy [...] Mnie się też nie udało z żonq... Od pięciu lat jestem sam i tyle czasu nie widziałem moich dzieciaków. Strasznie za nimi tęsknię, ale ich matka nie chce, by wiedziaty, że siedzę. Zanim tu trafitem, to przyrzektem im, że nie dam sięjuż zamknać, ale datem i stato się, jestem sam... Już chyba na zawsze. [S.T. — 45 lat, rozwiedziony, mieszkaniec małego miasta, wykształcenie zawodowe, dwukrotny recydywista, wyroki skazujące za handel narkotykami i zabójstwo]

Badania własne ukierunkowane były także na poszukiwanie związku między postawami wychowawczymi rodziców badanych recydywistów a deklarowanymi przez nich stylami wychowania własnych dzieci. Badaniem objęto jedynie recydywistów posiadających dzieci, bez względu na ich obecny stan cywilny (mąż, partner, rozwodnik, wdowiec) oraz typ rodziny własnej (pełna, niepełna). Wyniki badania upoważniają do postawienia tezy, że recydywiści powielają najczęściej dewiacyjny model życia rodziny pochodzenia. Ich rodziny własne są bowiem patologiczne, dotknięte traumą nierówności społecznej, piętnem przestępczości, wieloproblemowe, pełne napięć i traumatyzujących relacji. Cechuje je znacznie osłabiona sieć więzi osobowych i brak lub niewielkie możliwości osiągania dóbr materialnych. Relacje recydywistów z własnymi dziećmi są podbudowane postawami wychowawczymi przeniesionymi przez nich z rodzin pochodzenia w postaci wzorca lustrzanego lub wzorca odwróconego.

Okazało się, że postawa rodzicielska kochająco-wyrozumiała (,gorąca”) doświadczana przez badanych recydywistów w dzieciństwie, zwłaszcza prezentowana przez obojga rodziców, jest odwzorowywana przez nich w rodzinie własnej. Recydywiści doświadczający tego typu postaw rodzicielskich, wychowujący się w atmosferze wzajemnej życzliwości, wspomagani rozwojowo, 
kochani i rozumiani, w dorosłości stali się rodzicami skoncentrowanymi na dziecku, konsekwentnymi, wymagającymi, ale także rozsądnie kontrolującymi, komunikującymi się zwrotnie i negocjującymi.

Recydywiści, którzy byli nadmiernie karani i dyscyplinowani przez swoich rodziców (postawa „zimna”), wykazują wobec własnych dzieci dwa rodzaje postaw: albo są kochającymi i wyrozumiałymi ojcami, chcącymi dać swoim dzieciom wszystko to, czego sami nie doświadczyli w dzieciństwie, a zwłaszcza miłość, czułość i szacunek, albo nie dają swoim dzieciom wsparcia i nie interesują się ich sprawami, są obojętni, a kontakty z nimi utrzymują z poczucia rodzicielskiego obowiązku. Wzorzec wyniesiony z rodziny pochodzenia przejawiał się chłodem emocjonalnym, brakiem możliwości dyskusji i wyrażania przez dzieci własnego zdania, jak też silną kontrolą rodzicielską i zachowaniami rodziców skutkującymi często u dzieci traumą przeniesioną w dorosłość.

$\mathrm{Z}$ kolei recydywiści wychowywani w domu rodzinnym, w którym dominowała postawa rodzicielska obojętno-odrzucająca („letnia”), są wobec własnych dzieci rygorystyczni, kontrolujący, wymuszający posłuszeństwo, narzucający reguły i normy postępowania oraz karzący za ich przekraczanie.

Recydywiści wychowujący się w atmosferze chłodu emocjonalnego i wymagań przerastających często ich możliwości, w dorosłości nie angażują się w sprawy własnych dzieci, okazują im niewiele zainteresowania i nie dają wsparcia lub opisują siebie w roli rodziców wrażliwych na potrzeby dzieci, rozumiejących i dających im pole do dyskusji oraz szanujących podejmowane przez nie decyzje.

\section{Niewydolność ekonomiczna rodziny własnej}

Wyniki badań własnych upoważniają do postawienia tezy, że recydywiści wychowywani w głęboko dysfunkcyjnych środowiskach rodzinnych nabyli niekorzystne wzorce socjalizacyjne i przenieśli je w dorosłe życie. Podobnie jak ich rodzice wykazują deficyty kompetencyjne, posiadają niski poziom wykształcenia i są uwikłani w uzależnienia. Część z nich bezpowrotnie straciła kontakt z osobami bliskimi — żonami, konkubinami, dziećmi i żyje samotnie, tęskniąc za ciepłem ogniska domowego. W ogólnym obrazie widoczne jest ich pragnienie powrotu do rodziny, nostalgia za dziecięcą beztroską i przebłyskami szczęśliwych chwil. Ale ci, którzy nadal funkcjonują w związkach i współtworzą rodzinę, mówią o problemach związanych najczęściej z jej złą sytuacją materialną.

Pomimo tego, że rodziny z problemem penitencjarnym w większości przypadków wykazują upośledzenie funkcji ekonomicznej, to wynik badania wskazuje, że większość z nich nie korzysta ze świadczeń instytucji pomocy społecznej. Okazuje się, że rodziny badanych recydywistów są często wspomagane przez osoby z dalszych kręgów rodzinnych lub radzą sobie, uzyskując niskie dochody z pracy etatowej lub doraźnej (na wsi z pracy sezonowej), pozwalającej im egzystować na podstawowym poziomie. Pracę podejmują zarówno żony/konkunbentki, jak i ich dorosłe dzieci pozostające we wspólnym gospodarstwie domowym. 
W rodzinach wielopokoleniowych budżet rodziny zasilają znacznie seniorzy, dzieląc się z pozostałymi członkami rodziny wpływami z emerytury lub renty.

W tym momencie sytuacja mojej rodziny jest dosyć ciężka, nie powiem, nie jest bardzo tragiczna lub na skraju ubóstwa, ale też bez rewelacji. Ja dosyć dobrze zarabiatem, gdy bytem na wolności. Teraz dzieci i moją konkubine, która obecnie nie pracuje, utrzymuja jej rodzice. Płaca za wszystko, czyli mieszkanie, utrzymanie, plus jakieś raty za sprzęt lub kredyty, które mieliśmy. Jest ciężko, ale nie dramatycznie, daja sobie jakoś radę, za co im się chyba nigdy do końca życia nie odpłace, za ta pomoc. [M.K. - 40 lat, kawaler, mieszkaniec dużego miasta, wykształcenie zawodowe, recydywista wielokrotny, wyroki skazujące za pobicia i rozboje]

Partnerki badanych recydywistów są w większości przypadków słabo wykształcone i posiadają niskie kwalifikacje zawodowe. Pozbawione finansowego wsparcia mężów/konkubentów, podejmują się różnorakich zajęć, by utrzymać rodzinę. Głęboka dysfunkcja ekonomiczna rodziny skłania jednak część $\mathrm{z}$ nich do korzystania z pomocy społecznej.

Moje dzieciństwo może nie do końca było szczęśliwe. Może dlatego, bo nie miatem tego, co mieli inni. Fajnych rzeczy, fajnych ciuchów... Wszystko sobie sam musiałem organizować, bo w domu nie było pieniędzy. Rodzice pracowali, ale na najniższych stawkach. Nie mieli wyksztatcenia. Miłości mi jednak nie brakowało. Gdy bytem juz trochę starszy, to miatem kumpli, $z$ którymi kradtem. Rano wychodzitem z domu i na wieczór wracatem. Frajda z tego byta, bo nie zastanawialiśmy się nad tym, co robiliśmy, to znaczy fajne było ryzyko i ten dreszczyk adrenaliny... [...] Obecnie mam wtasna rodzinę. Mam narzeczona i 8-letnie dziecko. Nasza sytuacja materialna nie jest i nigdy nie była dobra - musieliśmy korzystać z pomocy społecznej. Moja narzeczona pracuje, bo zawsze sobie potrafita, jakoś sama dać radę. Jak siedziałem wcześniej, to mnie caty czas odwiedzała, wynajmowała sama mieszkanie, pracowała, zajmowała się dzieckiem i jeszcze jeździła do szkoły. Za pierwszym razem siedziałem prawie 4 lata za kradzieże przeważnie, a teraz też za to samo. [S.W. - 28 lat, konkubent, mieszkaniec miasta średniej wielkości, wykształcenie gimnazjalne, jednokrotny recydywista, wyroki skazujące za kradzieże].

Mam żonę i 4-letniego syna. Mam z nimi dobre relacje, z każdym dniem jest co raz lepiej. Jak się nie widzimy, to przez telefon się styszymy, no ale jak dochodzi do kontaktu, że się widzimy, to naprawdę syn wiesza mi się na szyi i jest naprawdę niesamowity. Z żona to troche przygasty relacje, no ale jestem typem faceta, który się łatwo nie poddaje, szczególnie, jeśli coś czuje. Kocham ja bardzo i nie dam za wygrana. Po tych 5 latach co przeszliśmy razem. Wiem, że nie jest jej lekko. Żona siedzi sama w domu z synem. Mieszka teraz ze swoja matka, znaczy moja teściowa, która pracuje. Czasem ma 
jakąś pracę, przeważnie dorywczq. Ale myślę, że to ja jestem raczej od tego, aby zapewnić rodzinie byt, opieke, żeby się nie martwili o nic. Przynajmniej jest takie moje myślenie. Zreszta jak tylko się poznaliśmy, to powiedziałem, $\dot{z}$ e nie pozwole na to, żeby ona kiedykolwiek pracowata, bo od tego jestem ja. W sumie w obowiazkach domowych kontrole przejmowatem tez ja, w gotowaniu, ale też pomagałem sprzątać. Ona widzi też moje minusy. Dostałem od niej tak zwang ostatniq szansę i staram się caty czas. Jak mam przepustki, to robię kolacje, idziemy do kina, rozmawiamy, staram się te nasze relacje polepszyć. Jest ciężko, ale nie damy się. Teściowa pomaga, a i moja mama też nas wspiera, na ile może. Korzystamy z pomocy społecznej nie

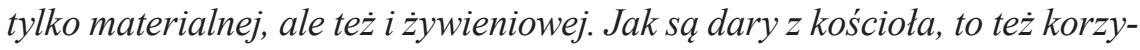
stamy. Po prostu, jeśli jest możliwość, to jak najbardziej idziemy i bierzemy. [S.W. - 29 lat, żonaty, mieszkaniec małego miasta, wykształcenie zawodowe, jednokrotny recydywista, wyroki skazujące za kradzieże].

Niektórzy osadzeni przyznawali, że w odruchu poczucia odpowiedzialności, w przerwach wolnościowych starali się znaleźć jakąkolwiek pracę, by wspomóc silnie osłabioną ekonomicznie rodzinę, borykającą się z wieloma problemami dnia codziennego różnorakiej natury, a co najważniejsze bezradną w obliczu niedostatku lub braku zasobów finansowych pozwalających na regulowanie podstawowych należności za czynsz, energię elektryczną czy media. Nie było to dla nich łatwe zadanie przede wszystkim z uwagi na karalność i niechęć pracodawców do zatrudniania byłych więźniów. Niemożność odnalezienia się na rynku pracy oraz długotrwały stan deprywacji potrzeb całej rodziny skłaniał ich do korzystania z wcześniej nabytych, przestępczych rozwiązań.

Reasumując, rodziny z problemem przestępczości charakteryzuje międzypokoleniowa transmisja dysfunkcjonalności. Narracje badanych recydywistów w pełni potwierdzają tę tezę, gdyż zdecydowana większość z nich pochodzi z rodzin polidysfunkcyjnych, dotkniętych chorobą alkoholową obojga lub jednego z rodziców, przemocą i przestępczością. Były to rodziny z nieustabilizowaną sytuacją materialną, często zaniedbane kulturowo, obciążone problemami, i słabymi kompetencjami życiowymi jej członków. Niskie kwalifikacje i kompetencje zawodowe pozwalały rodzicom albo na pracę etatową nisko płatną i wymagającą wykonywania dodatkowych prac zarobkowych, albo uzyskiwanie krótkoterminowego zatrudnienia w ramach podjętych prac dorywczych lub sezonowych. Na pełnym etacie zatrudnieni byli najczęściej rodzice recydywistów z dużych i średniej wielkości miast. Rodziny mieszkające na wsi utrzymywały się w większości przypadków z pracy na roli, gospodarząc i uzyskując środki finansowe ze sprzedaży płodów rolnych.

Z uwagi na niski poziom wykształcenia oraz kwalifikacji zawodowych osób strategicznych dla funkcjonowania rodziny, ponad $2 / 3$ rodzin pochodzenia badanych recydywistów, zmuszonych było do uzupełnienia braków finansowych poprzez pobieranie świadczeń z pomocy społecznej (częściej czyniły to rodziny o strukturze pełnej niż niepełnej oraz rodziny wielodzietne). Ponad połowa 
badanych rodzin doświadczała skutków choroby alkoholowej, którą dotknięty był najczęściej ojciec, co znacznie osłabiało rodzinę również pod względem finansowym. Były to więc rodziny nieporadne ekonomicznie, balansujące często na granicy ubóstwa i niepodejmujące starań w kierunku polepszenia kondycji finansowej rodziny. Prawdopodobnie był to skutek długotrwałego pobierania świadczeń socjalnych i wytworzenia się postaw roszczeniowych oraz niskiego poziomu sprawności komunikacyjnych i umiejętności radzenia sobie w sytuacjach trudnych.

W retrospektywnych odniesieniach badanych recydywistów do własnego dzieciństwa, w większości przypadków wybrzmiewa jednak troska rodziców o utrzymanie rodziny oraz przekonanie, że ich rodziny pochodzenia były materialnie dobrze zabezpieczone. Ten pozorny dysonans pomiędzy wynikami badania wykonanego na podstawie paradygmatu normatywnego a wynikami badania opartego na paradygmacie interpretatywnym, wynika prawdopodobnie $\mathrm{z}$ zestawienia danych liczbowych przetworzonych statystycznie i nieoddających kontekstu funkcjonowania rodzin, z wynikami analizy przekazów ustnych i pisemnych odnoszących się do wspomnień z dzieciństwa, zabarwionych silnymi emocjami. Pamiętać należy, że dzieci w zupełnie inny sposób postrzegają problemy rodzinne niż dorośli. Są na takim etapie rozwoju osobniczego, że zwykle nie identyfikują zagrożeń czy pojawiających się trudności. Określenie „pozorny dysonans” nie oznacza zatem sprzeczności. Badanie komplementarne pokazało różnice w postrzeganiu zabezpieczenia materialnego rodziny przez osoby dorosłe i dzieci. Niewątpliwie swój udział miały w tym także zniekształcenia atrybucyjne, czynniki temporalne oraz osobowościowe osób badanych.

Zastosowana w badaniu triangulacja metod badawczych umożliwiła wyodrębnienie czterech postaw wychowawczych powiązanych ze stylami wychowania. Z pedagogicznego punktu widzenia najbardziej pożądana jest postawa wychowawcza kochająco-wyrozumiała („gorąca”). Z kolei trzy postawy: ambiwalentna — „chwiejna” (styl wychowania — niekonsekwentne oddziaływanie), obojętno-odrzucająca — „letnia” (styl liberalny) oraz dyscyplinująca — „zimna” (styl autokratyczny) stanowią grupę ryzyka, gdyż skutkują bezradnością i niewydolnością wychowawczą rodziców, niepowodzeniem szkolnym i niedostosowaniem społecznym dzieci i młodzieży.

Pogłębiona analiza narracji recydywistów odnoszących się do ich wspomnień z dzieciństwa wskazuje na dominację dwu postaw rodzicielskich. Pierwszą z nich jest postawa kochająco-wyrozumiała (,gorąca”). We wspomnieniach zdecydowanej większości osób badanych przewija się obraz rodziców kochających mimo wszystko i wspierających. W wielu narracjach uwypuklany jest silny związek z matką i słaby z ojcem. Badani podkreślali, że rodzice byli stale zapracowani, nie poświęcali dzieciom zbyt wiele uwagi, ale matki były troskliwe i rozumiejące. Ojcowie byli natomiast często nieobecni, wymagający i surowi. Brak czasu oraz duże obciążenia związane z utrzymaniem rodziny i codziennymi obowiązkami, skutkowały finalnie porażką wychowawczą. Należy podkreślić, że niemal 
we wszystkich odniesieniach badanych recydywistów do rodziny pochodzenia widoczna była tendencja do usprawiedliwiania postępowania rodziców i ukazywania ich w jak najlepszym świetle. Drugą z najczęstszych postaw rodzicielskich była postawa ambiwalentna („chwiejna" + styl liberalny) o silnym potencjale destrukcyjnym, powiązana z niekonsekwentnym oddziaływaniem. Przejawiała się ona $\mathrm{w}$ zachowaniach przemocowych ojców i w tolerancyjnym podejściu matek. Niespójność postaw wychowawczych skutkowała dziecięcą samotnością, lękiem przed krytyką, nadmiernym kontrolowaniem i karą, a finalnie utratą przez rodziców wpływu wychowawczego i wikłania się dzieci w niekorzystne układy rówieśnicze.

Należy podkreślić, że rodzice badanych recydywistów posiadających zewnętrzne poczucie kontroli, wykazywali częściej postawę obojętno-odrzucającą oraz ambiwalentną niż postawę kochająco-wyrozumiałą czy karząco-dyscyplinującą. Te dominujące postawy wychowawcze częściej skutkują u dzieci wycofaniem, brakiem umiejętności radzenia sobie z problemami i niedostosowaniem społecznym niż pozostałe typy postaw.

W większości przypadków badani recydywiści wychowywali się w rodzinach rozbitych, gdzie miejsce ojca zajmował po pewnym czasie ojczym. Pojawienie się nowej osoby w rodzinie generowało najczęściej napięcia, konflikty, niezaspokajanie dziecięcych potrzeb, zwłaszcza emocjonalnych, poczucie krzywdy i niesprawiedliwości. Dzieci formalnie w nich zakotwiczone szukały na zewnątrz ukojenia, zrozumienia i akceptacji, zaspokajały te potrzeby w nieformalnych grupach rówieśniczych o charakterze przestępczorodnym.

Relacje recydywistów $\mathrm{z}$ własnymi dziećmi są podbudowane postawami wychowawczymi przeniesionymi przez nich $\mathrm{z}$ rodzin pochodzenia $\mathrm{w}$ postaci wzorca lustrzanego lub wzorca odwróconego. Porównanie wspomnień z dzieciństwa oraz narracji dotyczącej rodziny własnej badanych recydywistów pozwoliło na identyfikację zjawiska przenoszenia w dorosłe życie również rodzinnych wzorców alkoholowych. Ponad połowa ogółu badanych recydywistów to alkoholicy lub narkomani pochodzący z rodzin alkoholiczych, w młodości nadużywający środków psychoaktywnych. Pomimo traumatycznego doświadczenia z powodu rozwodu rodziców, badani recydywiści w dorosłości powielali także wzorzec rodziny rozbitej. Problemy małżeńskie pojawiały się często już przed pierwszym uwięzieniem. Pobyt w więzieniu, trawiące ich uzależnienia, niemożność odnalezienia się w roli męża i ojca, trudna sytuacja materialna rodziny, powodowały kumulację napięć i powolny rozpad więzi rodzinnych, aż do momentu przypieczętowanego prawnie rozwodu i rozpadu rodziny. Te rodziny recydywistów, które przetrwały, są napiętnowane społecznie, osamotnione i tkwią w gąszczu nierozwiązanych problemów. Chcąc utrzymać rodzinę, żony/konkubiny sięgają po pomoc społeczną. Nie rozwiązuje to jednak znacząco ich trudnej sytuacji materialnej.

Niedostosowanie społeczne, patogenne wzorce rodzinne i niekorzystne sploty okoliczności były zaczynem rozwoju myślenia przestępczego, zmiany trajektorii życiowej i przyjęcia przestępczego stylu życia przez badanych recydywistów. 
Zahamowanie kariery edukacyjnej spowodowało u większości z nich obniżenie zdolności do funkcjonowania na rynku pracy (niski poziom wykształcenia, niskie kwalifikacje zawodowe lub ich brak).

\subsubsection{Postrzeganie przyczyn własnej porażki readaptacyjnej}

Liczne opracowania naukowe i raporty badawcze wskazują na niski status społeczny byłych więźniów. Stanowią oni grupę ryzyka zagrożoną wykluczeniem ekonomicznym i mieszkaniowym, a w sferze społecznej — relacyjnym. Narastające dolegliwości readaptacyjne, w tym nierozwiązane problemy finansowe, mieszkaniowe oraz obciążenia osobowościowe, charakterologiczne i uzależnieniowe sprawiają, że większość byłych więźniów wikła się w sytuacje przestępczorodne, popełnia czyny karalne i podlega ponownej ekskluzji.

Podłożem, z którego wyrastają problemy przystosowawcze byłych więźniów, jest etykieta kryminalisty, która w wielu przypadkach odcina im możliwości wpasowania się w nurt życia społecznego zgodnie z obowiązującymi normami i blokuje rozpoczęcie nowego, konstruktywnego etapu życia. Konsekwencją stygmatyzacji jest silnie obciążające poczucie niesprawiedliwości społecznej oraz bolesne doświadczanie braku wsparcia w wysiłkach readaptacyjnych. Winą za swoje porażki readaptacyjne ekswięźniowie obarczają najczęściej społeczności lokalne i instytucje, które są prawnie zobowiązane do ich wspomagania w powrocie do życia na wolności. Zarzucają im obojętność, brak empatii i pozorowanie działań pomocowych. W większości przypadków czują rozgoryczenie, są sfrustrowani i bezradni. Pozostawieni sami sobie, nie mogąc odnaleźć się w nowej, często ponownie opresyjnej sytuacji, „odkurzają” swoją etykietę kryminalisty i radzą sobie w sposób wcześniej znany — łamią prawo.

Potrzebowatem pomocy od kuratora. Chciatem, by mi pomógt w uzyskaniu miejsca do noclegu i pracy. Od ludzi z mojej wsi i tam, gdzie szukałem pracy, oczekiwałem tego, żeby nie oceniali mnie tylko przez mój pobyt $w$ więzieniu. Niestety, zawsze spotykatem się z negatywnym nastawieniem do mojej osoby. Nie mogłem znaleźć pracy i to spowodowato, że zaczqtem ponownie kraść, żeby mieć pieniadze na życie. Miatem też $w$ drodze kolejne dziecko i nie byto pieniędzy na zakup ciuszków i innych rzeczy niezbędnych do opieki nad nim. Wiem, że nie powinienem kraść, przecież chciatem być jak inni, mieć rodzinę, pracę i za nic nie chciałem wrócić do pierdla, ale co miatem zrobić... Pieniadze nie rosna na drzewach, a bez nich nie można normalnie żyć. [P.M. — 33 lata, kawaler, mieszkaniec wsi, wykształcenie średnie, czterokrotny recydywista, wyroki skazujące za wymuszenia rozbójnicze i rozbój z użyciem niebezpiecznego narzędzia]

Po zakończeniu pierwszej kary pozbawienia wolności miatem problem ze znalezieniem pracy, ale większość pracodawców wymaga zaświadczenia o niekaralności, no i po sprawie... $W$ pierwszych dniach po wyjściu 
oczekiwatem od kuratora pomocy w znalezieniu jakiejś pomocy finansowej. Miatem wprawdzie przystowiowy dach nad głowa, ale pozostatem bez środków do życia. Jedyna pomoc, jaka uzyskatem od kuratora, to było 200 złotych, za które miatem żyć dopóki nie znajde pracy, ale samo znalezienie pracy nie pozwalato na petne utrzymanie sie. Pierwsze wynagrodzenie wypłacane jest po okresie jednego miesiąca od zatrudnienia, bez możliwości wzięcia zaliczki, więc kwota przyznana mi przez kuratora byta w moim przypadku absurdalna, niewystarczająca na opłate podstawowych mediów $i$ zakup artykułów spożywczych. Wszystko to, wraz z wcią̇ rosnącym zadlużeniem za mieszkanie, przyczynito się do popetnienia przeze mnie kolejnych przestępstw. Sytuacja ta powtórzyła się, gdy drugi raz opuściłem zakład karny. Zmuszony bytem do zdobycia pieniędzy na życie w nielegalny sposób, ponieważ nie moglem szybko znaleźć pracy z powodu mojej karalności. Jedyna, jaka znalaztem, była praca na czarno na budowie, ale byto to już po tym, gdy popetnitem kilka przestępstw, za które odbywam teraz karę. Gdy się tak zastanawiam nad tym wszystkim, to wydaje mi się, że głównym powodem mojej recydywy byt brak pomocy ze strony kuratora i negatywne naznaczenie, no i pozostawienie mnie samemu sobie. Tam, gdzie mieszkam, a może i szerzej, jestem i zawsze już będę postrzegany jako ktoś z marginesu społecznego, komu nie można zaufać. Jedynym wyjściem jest zmienić miejsce i tak zrobię, jak stąd wyjde — nie będe już czekat na pomoc, wyjadę gdzie oczy poniosa... [L.L. — 29 lat, kawaler, mieszkaniec miasta średniej wielkości, wykształcenie gimnazjalne, dwukrotny recydywista, wyroki skazujące za kradzież, handel narkotykami i oszustwa finansowe]

Szczegółowa analiza wypowiedzi osób badanych na temat ich własnej porażki readaptacyjnej, a także wyniki analiz statystycznych dały podstawy do wyodrębnienia trzech głównych czynników inicjujących niepowodzenie readaptacyjne, powiązanych z innymi zjawiskami potęgującymi ich negatywny wpływ.

\section{Trudności w pozyskaniu zatrudnienia/brak pracy}

Trudności piętrzące się przed byłymi więźniami poszukującymi pracy są niekiedy tak duże, że skutkują bezrobociem długotrwałym albo w przypadku szczęśliwców, co najmniej miesięcznym. Oznacza to brak wystarczających środków na utrzymanie siebie i rodziny. Zdesperowani ekswięźniowie podejmują chaotyczne i nieefektywne próby podjęcia jakiegokolwiek zatrudnienia. I właśnie te dwa czynniki - brak pracy i środków do życia są w ocenie badanych recydywistów odpowiedzialne najczęściej za ich porażkę i powrót do przestępstwa. W zestawieniu z innymi grupami poszukającymi zatrudnienia, niemożność pozyskania pracy przez ekswięźniów wynika przede wszystkim z faktu defaworyzacji tej grupy na rynku pracy. Poważnym problemem jest także etykieta kryminalisty, która w przypadku porównywalnych kwalifikacji 
i kompetencji osób karanych i niekaranych daje tym drugim zdecydowanie większe szanse na zatrudnienie.

Zjawisko defaworyzacji na rynku pracy wyjaśnia między innymi teoria uprzedzeń osobistych autorstwa Gary’ego S. Beckera, która odnosi się zasadniczo do dyskryminacji rasowej [za: Filer, Hamermesh, Rees 1996, s. 530-537], ale ma również zastosowanie w rozważaniach nad innymi rodzajami dyskryminacji, $\mathrm{np}$. osób niepełnosprawnych czy niedostosowanych społecznie. W rozumieniu Beckera posiadanie subiektywnych uprzedzeń (ang. taste for discrimination) generuje zachowania dyskryminujące wobec określonych jednostek i grup. Piętno kryminalisty (przestępcy) jest zatem źródłem dyskryminacji oraz defaworyzacji osób skazanych na rynku pracy. Zjawisko to prowadzi do segregacji zawodowej [za: Ehrenberg, Smith 2000, s. 530-537]. W omawianym przypadku źródłem nierówności są pracodawcy, lokowani $\mathrm{w}$ jednym $\mathrm{z}$ trzech modeli dyskryminacji, które dostarcza teoria Beckera [za: Bosworth, Dawkins, Stromback 1996, s. 331-333). Do osób z etykietą byłego przestępcy kierowanych jest niewiele ofert zatrudnieniowych, co sprawia, że wielu z nich nie radzi sobie z problemem pozyskania w sposób legalny środków finansowych. Pomimo oferowanych pracodawcom ulg z tytułu zatrudnienia byłych więźniów, nadal unikają oni przyjmowania do pracy osób obciążonych wyrokami sądowymi.

Powyższą tezę potwierdzają wyniki badania przeprowadzonego z zastosowaniem strategii ilościowej [Nowak 2019a], które wskazują na istotne zależności pomiędzy reakcjami pracodawców a miejscem zamieszkania, rodzajem recydywy, wiekiem i poziomem wykształcenia badanych recydywistów. Okazało się, że najczęstszą postawą pracodawców wobec byłych więźniów poszukujących pracy jest postawa akceptująca. Problem z postrzeganiem ekswięźniów w roli pracowników mają jednak pracodawcy z miast średniej wielkości, którzy podobnie jak pracodawcy z dużych miast, istotnie częściej niż osoby z mniejszych miejscowości przejawiają wobec byłych więźniów postawę odrzucającą. Dotyka to zwykle byłych więźniów do 30 rż., słabo wykształconych i skazanych na karę izolacji w zakładzie typu zamkniętego. Potwierdzają to częściowo badania wykonane przez innych autorów, które wykazały, że byli więźniowie z zakładu karnego typu półotwartego częściej podejmują pracę na wolności niż z zakładu typu zamkniętego (zwłaszcza długoterminowi), którzy w większym stopniu doświadczają negatywnych skutków izolacji więziennej i stygmatyzacji [por. Fidelus 2013] oraz marginalizacji społecznej [por. Florczykiewicz 2013]. Niechętnie zatrudniani są także ekswięźniowie seniorzy. Pracodawcy z terenów wiejskich i małomiasteczkowych są bardziej tolerancyjni, gdyż albo są zainteresowani umiejętnościami ekswięźniów, adekwatnymi do wykonywania określonej pracy, albo poszukują pracowników wykonujących prace fizyczne, niewykwalifikowanych i nisko wynagradzanych.

Wyniki badania przeprowadzonego na podstawie strategii ilościowej ujawniły istotną zależność między miejscem zamieszkania a sytuacją ekonomiczną osób badanych. Okazało się, że im mniejsza miejscowość, tym lepsza jest sytuacja ekonomiczna osób mieszkających na jej terenie. Wynik ten koresponduje z deklaracjami 
niemal połowy ogółu badanych recydywistów mieszkających na wsiach, które odnoszą się do problemów z uzyskaniem zatrudnienia [Nowak 2017a]. Jest to trend wskazujący, że byli więźniowie powracający do małych enklaw społecznych (wieś, małe miasto) mają większą szansę na podjęcie zatrudnienia, głównie jako pracownicy fizyczni przy pracach sezonowych oraz posiadają lepsze zaplecze ekonomiczne, gdy wystąpi przerwa w zatrudnieniu, wynikająca z naturalnego cyklu prac polowych niż osoby żyjące w miastach średniej i dużej wielkości.

Po wyjściu na wolność potrzebowatem pieniędzy na życie. Z praca byto różnie. Większość pracodawców patrzyła na mnie z nieufnościa, gdyż bytem karany, a w Urzędzie Pracy nie dostałem żadnej oferty. Z pomoca finansowa byto tak, ze kurator wystat mnie do MOPS-u, a MOPS z powrotem do kuratora. Jedni i drudzy twierdzili, że nie maja dla mnie pieniędzy na zapomogę. Co do mojego przestępstwa, to nikt się nie przyczynit, tylko $i$ wyłacznie ja i moja gtupota oraz brak środków do życia. [M.K. — 29 lat, żonaty, mieszkaniec dużego miasta, wykształcenie średnie, jednokrotny recydywista, wyroki skazujące za rozboje]

Gdy wyszedtem na wolność, to ze względu na karalność ciężko było znaleźć jakaś pracę. Po zgłoszeniu się do opieki społecznej zostałem odestany $z$ tzw. kwitkiem. Powiedziano mi, że nie należy mi sie pomoc, bo miatem pieniadze na żelaznej kasie, ale nikt nie wziąt pod uwage, że to co miatem na żelaznej kasie, wpłacić musiałem na grzywny, żeby 3 miesiace wcześniej wyjść z więzienia. Po uzyskaniu informacji, że należy mi się pomoc od kuratora, dostatem od niego aż 70 złotych i informacje, że gdybym zglosit się na poczatku roku, to dostałbym więcej, a teraz budżet już się skończyt. Gdy wychodzitem z zaktadu, moje dziecko miało 4 latka i nie byto kasy na utrzymanie rodziny. To postanowitem, raz jeszcze podjać ryzyko, włamać się do takiej wypasionej chatupy, ale zabezpieczyli się, syreny zawyly i impreza się zakończyła - wrócilem i znów posiedzę tu sobie trochę... [L.Z. - 26 lat, rozwiedziony, mieszkaniec dużego miasta, wykształcenie gimnazjalne, jednokrotny recydywista, wyroki skazujące za rozbój i kradzież z włamaniem].

Problemy z zatrudnieniem byłych skazanych rosną wraz z wielkością miejscowości, do której powracają po zakończeniu kary izolacji więziennej [Nowak 2017a]. W dużych miastach rynek pracy jest wprawdzie zdecydowanie większy niż w małych miejscowościach, ale znacznie uboższy w oferty dla grupy ekswięźniów. W szczególnie trudnej sytuacji są osoby niemające wsparcia w rodzinie pochodzenia lub/i swojej własnej. Są oni osamotnieni i zagubieni. Nie widząc perspektyw w życiu na wolności i nie mając wsparcia społecznego, szybko powracają do przestępstwa.

Po wyjściu na wolność nie otrzymatem żadnej pomocy od kuratora, który powinien wspierać mnie $w$ poszukiwaniu pracy chociażby $w$ ten sposób, 
by zarekomendować mnie u jakiegoś pracodawcy. Powiem krótko, po wyjściu z pudła skazany nie ma żadnych szans, by znaleźć pracę. Ja nie mam szans na pracę. $W$ moim mieście rynek pracy jest skromniutki, a do tego mnie, człowieka skazanego, nikt nie zatrudni. Musiałbym jechać gdzieś dalej za praca. To wiąze się niestety z finansami, a tych nie ma, rodziny też nie ma... No to wrócitem do tego, co umiem najlepiej-zaczątem znów kraść. [A.C. 37 lat, rozwiedziony, mieszkaniec miasta średniej wielkości, wykształcenie zawodowe, trzykrotny recydywista, wyroki skazujące za kradzieże]

Recydywista zostatem przez powrót do narkotyków, alkoholu i dawnych kolegów. Po wyjściu na wolność potrzebowatem pomocy pieniężnej, która pomogłaby mi stanać na nogi, ale jej nie otrzymałem. Nie mogłem też znaleźć pracy, a żyć za coś trzeba było. Kurator tylko wymagat, ale sam ze swojej strony nie wykazal żadnej inicjatywy. Pomoc spoleczna też mnie nie wspierała, gdyż zapomoga, która mi przyznano, nie starczyta nawet na przeżycie jednego tygodnia. W takiej sytuacji chęć zdobycia szybkich pieniędzy byta wielka, a że nadarzyta się okazja, to skorzystatem... [P.S. 36 lat, kawaler, mieszkaniec dużego miasta, wykształcenie zawodowe, trzykrotny recydywista, wyroki skazujące za posiadanie narkotyków, kradzież z włamaniem i oszustwa].

Pozbawieni możliwości pozyskania stałego zatrudnienia byli więźniowie korzystają zwykle z krótkoterminowych, nieformalnych ofert pojawiających się „W szarej strefie” lub wykonuja prace dorywcze. Niemal ze wszystkich wypowiedzi recydywistów wybrzmiewa żal, poczucie osamotnienia, bezradność oraz utyskiwanie na brak wsparcia społecznego.

Ponownie popetnitem przestępstwo, ponieważ przez rok nie mogłem znaleźć pracy. Ludzie nie chca zatrudniać skazanych, boja się ich i ja to rozumiem... Kurator nie pomógt mi w poszukiwaniu pracy, a na opieke społeczna też nie mogłem liczyć. Miałem na utrzymaniu narzeczona i córkę. Dopóki miałem dorywcze prace, to wiązałem koniec z końcem. Gdy praca się skończyła, to musiatem utrzymać rodzinę $i$ dlatego znowu zaczątem kraść i dilowatem też trochę. Gdyby mi ktoś pomógt - opieka społeczna czy kurator - to nie musiatbym tego robić, ale sytuacja mnie do tego zmusita. [M.K. - 39 lat, kawaler, mieszkaniec małego miasta, wykształcenie podstawowe, dwukrotny recydywista, wyroki skazujące za posiadanie i rozprowadzanie narkotyków oraz kradzież]

W wyżej zacytowanych wypowiedziach recydywistów wybrzmiewa symptomatyczna, negatywna ocena kuratorów sprawujących dozór, wystawiana w odniesieniu do obowiązku niesienia pomocy byłym więźniom w poszukiwaniu pracy. W podobnym tonie są także cytowane poniżej fragmenty narracji. Recydywiści najczęściej opisywali bierność kuratorów wobec problemów nękających osoby, które powinni wspierać w wysiłkach readaptacyjnych. 
Po pierwszym wyjściu z więzienia nie potrzebowatem żadnej pomocy, ale i tak nikt mi jej nie zaoferowat. Natomiast po drugim wyjściu bardzo jej potrzebowatem i nawet sam o nia poprosilem, ale jej nie otrzymatem. Nic, poza talonem do jadtodajni dla bezdomnych. Potrzebne mi byto wsparcie finansowe, aby dokończyć edukację oraz normalna, nieupokarzająca praca. Kurator zajmowat się głównie straszeniem mnie. Nigdy nie wyszedt z jakakkolwiek inicjatywa. Kolejne przestępstwo popetnitem właśnie z powodów finansowych, bo inaczej nie dałbym rady przeżyć, gdyż prace, które mi oferowano jako osobie karanej, byty bardzo nisko opłacane, więc nie było szansy na normalne życie. [J.W. - 9 lat, kawaler, mieszkaniec dużego miasta, wykształcenie średnie, dwukrotny recydywista, wyroki skazujące za oszustwa, handel narkotykami i rozbój].

Miatem na utrzymaniu konkubinę $i$ córeczkę, rachunki za wynajmowany dom. Kurator mi nie pomógt nawet $w$ szukaniu pracy, a potrzeby mojej rodziny rosty. Na początku nawet nie myślatem, żeby kraść, bo na własna rękę szukatem prac dorywczych, ale to się szybko kończyto, a dziecko potrzebowato różnych rzeczy... To sprawiło, że z wielkim bólem serca zaczątem kraść i tak kradtem przez pót roku. Gdy znalazłem dobra prace u mojego wuja, który otworzyt szrot z autami, to po roku bytem już jego wspótwtaścicielem. Byto bardzo dobrze i nagle ktoś z kim kradtem, zostat złapany i mnie wsypat. Miałem dwie sprawy, za które zostatem skazany. Próbowatem to odroczyć w sadzie, ale mi tego nie zawiesili. Przez dwa lata jeszcze przebywatem na wolności i bytem bardzo zadowolony z naszego szrotu. Interes szedt świetnie, ale gdy mi przyszło wezwanie, żebym stawit się do więzienia, to wszystko runęło. Mój zwiąek się rozpadt. Nie mam kontaktu z moją córeczka kochaną, nawet nie mogę się z nią kontaktować telefonicznie. Gdy pracowatem, to nawet nie chodziło mi po głowie, żeby kraść, bo zarabiatem i to dobrze. Teraz przebywam w więzieniu i żatuję tego, że kradtem, ale z kolei za co bym utrzymat rodzinę. I tak już jej nie mam. Próbowatem pisać do kuratora, aby wnióst o zawieszenie moich wyroków, ale mi w tym nie pomógt. Obiecatem sobie, że jak tylko stąd wyjdę, już nigdy nie trafię do więzienia. Będę dalej prowadzić z wujem szrot i postaram się mieć kontakt z moja córka. [K.K. - 40 lat, kawaler, mieszkaniec małego miasta, wykształcenie podstawowe, trzykrotny recydywista, wyroki skazujące za kradzieże i paserstwo]

\section{Uzależnienie od środków psychoaktywnych}

Badania własne ujawniły także istnienie trendu wskazującego na problem uzależnienia od środków psychoaktywnych, najczęściej od alkoholu, dotykający częściej recydywistów pochodzących z małych miejscowości i wsi, w porównaniu z mieszkańcami średnich i dużych miast. Wynik ten koresponduje z innymi 
przeprowadzonymi przeze mnie badaniami [Nowak 2011] oraz wynikami badań innych autorów [m.in. Bartoszek, Kocka, Zielonka i in. 2016; Dzielska 2015], które wskazują, że problem związany z chorobą alkoholową występuje częściej w rodzinach wiejskich niż miejskich. Skazani powracający do swoich środowisk życia stają wobec problemów, których nie potrafili i nadal nie potrafią rozwiązać. W poczuciu niemocy i lęku przyjmują często unikowe strategie radzenia sobie, a najczęściej wikłają się w uzależnienie, zagłuszając niepokój. Nadużywanie alkoholu i innych środków psychoaktywnych w zestawieniu $\mathrm{z}$ niską tolerancją organizmu i impulsywnością, a także skłonnością do agresji skutkują przemocą i niszczą więzi rodzinne.

Po pierwszej odsiadce stracitem dom i statem się bezdomny. Brak pracy, brak pomocy ze strony rodziny $i$ totalny brak zainteresowania ze strony społecznej spowodowat, że aby przetrwać, musiatem gdzieś zdobyć pieniadze. Nie chodziło tylko o wydatki na takie zwyczajne życie. Żeby nie myśleć o tym, kim jestem i gdzie mnie los rzucit, zacząem ćpać... Brałem wszystko, co się nawinęto - znalezione $w$ śmietniku przeterminowane leki, które mieszałem z alkoholem $i$ inne świństwa, które przepalaty mi mózg. Po kradzieżach, jak miałem kasę, to kupowatem amfę i ćpatem do nieprzytomności, aż w końcu się uzależnitem. Żeby znów ćpać, musiatem znów kraść $i$ wkręciłem się w błędne koło. [B.G. - 48 lat, rozwiedziony, mieszkaniec wsi, wykształcenie podstawowe, czterokrotny recydywista, wyroki skazujące za kradzież, kradzieże z włamaniem i rozbój]

W moim przypadku główna przyczyna powrotu do przestęstwa byt problem z nadużywaniem przeze mnie alkoholu, które taczytem z psychotropami. Przez to, że wracałem do domu na potężnej bani, dochodziło do licznych kłótni pomiędzy mna a ojcem. Chciałem od ojca jedzenia i papierosów. Kradtem mu pieniadze na alkohol. $W$ stanie mocno nietrzeźwym zakłócałem ciszę nocna tym, że głośno stuchałem muzyki i używałem słów powszechnie uznawanych za obelżywe. Kopałem $w$ drzwi od kuchni, gdyz kuchnię rodzice zamykali na klucz, przez co nie mogtem dostać się do lodówki i do łazienki, by się umyć. Wracatem do domu bardzo późno, a wtedy już rodzice spali w kuchni — tam stało ich tóżko. Właśnie dlatego dochodzito do częstych awantur z udziatem moim i ojca, a czasem mtodszego brata. On mnie nie lubit, też czasami pit i rwat się do bójek. Taki byt agresywny po alkoholu, że i ja musiatem czasem uciekać do sqsiada, ponieważ byłem pijany $i$ wiedziatem, że bójka z nim grozi interwencja policji. To wszystko przyczyniło się do mojej recydywy. [A.L. - 33 lata, kawaler, mieszkaniec wsi, wykształcenie zawodowe, czterokrotny recydywista, wyroki skazujące za znęcanie się psychiczne i fizyczne nad rodziną oraz groźby karalne]

Głównym powodem mojego powrotu do przestępstwa byt alkohol. To przez niego straciłem rodzinę i przyjaciót. Jak piłem, to ciężko mi było w pracy myśleć i przez to nie raz z niej wyleciałem. Po opuszczeniu więzienia 
chciatbym na nowo wrócić do swojej ostatniej pracy, gdyż sobie poprzysiagłem, że nie będę już pit. Miatem wiele czasu na rozpatrzenie btędów, których przyczyna byt alkohol. Chciałbym mieć wsparcie swojej rodziny, ale jak rozmawiam z bliskimi, to nikt mi nie wierzy, że rzucę to świństwo. Tyle razy już się zarzekatem... Pamiętam jak moja młodsza córka miata komunię. Wszedtem grzecznie do kościoła - rozejrzatem się i zobaczytem swoja córkę. Odwrócitem się i wyszedtem, bo po drodze do kościoła spotkatem dawnych znajomych i poszliśmy $w$ tango - polato się morze alkoholu. Popadtem w alkoholizm i znów miatem zatargi z prawem. Próbowatem wszystkiego, ale alkohol nie odpuszczat, tylko on się liczyt. Jak siedziałem pierwszy raz, to jeszcze miałem rodzine i o niej marzytem, a to pomagato mi przetrwać. Po rozpadzie malżeństwa już zapomniałem o wszystkim, co się z rodzina wiazało. Tak byto lepiej... [S.I. — 52 lata, rozwiedziony, mieszkaniec miasta średniej wielkości, wykształcenie podstawowe, dwukrotny recydywista, wyroki skazujące za kradzieże]

Nikt nie przyczynit się do mojego powrotu do przestepstwa. To ja sam. Zaczałem na nowo brać prochy i zapijać je alkoholem. A stato się tak, gdyż miatem poważne problemy, na które napotkatem po wyjściu z zaktadu karnego. Nie mogłem znaleźć pracy i nie miałem innych zajęć, które wypetniatyby mi czas. Jeśli chodzi o wsparcie społeczne czy pomoc, to moim zdaniem nie istnieje coś takiego, albo to ja nie umiatem jej znaleźć, a może trafiałem na nieodpowiednich ludzi. Jedyne wsparcie, jakie otrzymatem, to dobre stowo. Dobre i to... Od ostatniej kary minęto 7 lat. W tym czasie wyszedtem z nałogu sam, bez leków i pomocy innych ludzi. Założytem rodzinę i mam 4-letniego syna i jedyne czego oczekuje po opuszczeniu więzienia, to pomoc w znalezieniu pracy oraz darmowej pomocy prawnej, bym mógł uregulować swoje sprawy finansowe i prawne. [E.P. - 32 lata, kawaler, mieszkaniec dużego miasta, wykształcenie średnie, dwukrotny recydywista, wyroki skazujące za rozbój i oszustwa].

Niektórzy badani recydywiści przyznawali się do bycia alkoholikami lub narkomanami oraz do podjęcia w zakładzie karnym walki o trzeźwe życie. Terapia pomagała im uporać się z problemem i odsłaniała rzeczywiste przyczyny powrotu do przestępstwa. Część z nich, dostrzegając w uzależnieniu główną przyczynę powrotności do przestępstwa i planując życie na wolności, deklaruje kontynuowanie terapii. Inni wręcz odwrotnie - bagatelizują swój problem lub otwarcie mówią o tym, że nie będą kontynuować terapii i wskazują, gdzie, kiedy i z kim świętować będą swoje wyjście na wolność. Takie wypowiedzi można traktować jako wskaźnik porażki resocjalizacyjnej oraz zapowiedź poważnych problemów readaptacyjnych po zakończeniu kary izolacji więziennej i powrotności do przestępstwa. Recydywa jest bowiem możliwą konsekwencją nierozwiązanych problemów związanych ze zdrowiem psychicznym skazanych i brakiem dalszej opieki terapeutycznej po zakończeniu kary izolacji [Caballero 
et al., 2011]. Większość badanych zdaje sobie jednak sprawę, że podjęcie terapii i uwolnienie się od własnych słabości, to jedynie wstęp do ułożenia sobie życia. Równie ważne jest ich wyposażenie w umiejętności społeczne niezbędne do efektywnego, samodzielnego poszukiwania i podjęcia zatrudnienia lub korzystania z pośrednictwa pracy. Jest to ważne przede wszystkim dla osób skazanych na długoletnie kary pozbawienia wolności, gdyż w trakcie pobytu w więzieniu tracą oni umiejętność konstruktywnego poruszania się w środowisku wolnościowym. Po latach alienacji społecznej nie odnajdują się w diametralnie zmienionej rzeczywistości, w gąszczu biurokratycznych wymogów oraz w lokalnej sieci wsparcia społecznego.

Gtównym powodem popetnianych przeze mnie przestępstw jest to, że jestem narkomanem. Jestem na programie metadonowym od 2003 r. Pierwszy raz, gdy wyszedtem z więzienia, to trzymatem się od prochów z daleka, ale umarta moja Babcia, która była dla mnie kimś bardzo ważnym i po jej śmierci załamatem się i zacząłem coraz częściej sięgać po narkotyki. Podczas odbywania wyroku zabrano mi mieszkanie i boję się, że sytuacja mnie przerośnie i wyląduję na ulicy. Będę musiat chyba znów kraść, żeby móc wynajać mieszkanie. Jestem inwalida II grupy i moja renta nie wystarczy nawet na wynajęcie jakiegoś pokoju. A młody już nie jestem i czas najwyższy założyć rodzinę. Oczywiście spróbuję znaleźć pracę, i o ile będzie to możliwe, będę się starat żyć uczciwie. Mam kilka pomystów na życie zgodnych z litera prawa. Jeśli jednak to nie wypali, będę musiał wyjechać z Polski i żyć jak do tej pory, czyli szybko, kochać mocno... Boję sie jednak tego, że przy wyjściu nie dostane pieniędzy, które umożliwityby mi zapłacenie za hostel $i$ na przeżycie do pierwszej wyptaty $i$ będę musiat zaczać kraść. Ale póki co jestem optymista i mam nadzieję na pomoc. Mam też nadzieję, że nigdy już nie wrócę za kraty. [T.O. — 44 lata, kawaler, mieszkaniec dużego miasta, wykształcenie średnie, jednokrotny recydywista, wyroki skazujące za fałszerstwo i kradzież]

Przyczyna mojego powrotu do przestępstwa jest alkohol, który jest moją największa stabościa. Jeżeli chodzi o wsparcie społeczne, to je dostatem poprzez umożliwienie mi uczestnictwa w programie AA, na który uczęszczam, a który mi bardzo pomaga. Zaczynam rozumieć swoje błędy, które wiem, że sa spowodowane nadmiernym spożywaniem alkoholu. Myślę, że po ukończeniu tych spotkań będzie lepiej. Doszedtem też do wniosku, że po wyjściu $z$ więzienia będę kontynuowat program AA, ponieważ dojrzatem już do tej decyzji $i$ wiem, że jest dla mnie bardzo dobra. [D.M. — 33 lata, kawaler, mieszkaniec dużego miasta, wykształcenie średnie, trzykrotny recydywista, wszystkie wyroki skazujące za jazdę samochodem pod wpływem alkoholu].

Pierwszy raz po opuszczeniu zakładu karnego niczego oprócz pracy nie potrzebowatem. Miatem wszystko, ale zbyt często sięgatem po alkohol i pod jego wptywem jeździtem samochodem. Dzisiaj jestem już po terapii 
$i$ jestem z tego bardzo zadowolony. Jak skończe odbywanie wyroku, to wrócę do rodzinnego miasta i zamieszkam z żona. Dobrze by jednak byto, żeby przed końcem kary ktoś pomógł mi ogarnać wszystkie wnioski urzędowe i załatwit pracę. [D.F. — 31 lat, żonaty, mieszkaniec miasta średniej wielkości, wykształcenie podstawowe, trzykrotny recydywista, wyroki skazujące za kradzieże i jazdę samochodem pod wpływem alkoholu].

Oczekiwatem od kuratora wsparcia w poszukiwaniu zatrudnienia, ale on nie byt $w$ stanie mi pomóc. Zanim znalazłem state zatrudnienie przez trzy lata bytem odprawiany $z$,kwitkiem”, ponieważ bytem karany. Prace ,wychodzitem" sobie sam i gdyby nie moja rodzina i jej pomoc, to pewnie nie dałbym rady. Udało mi się ,utrzymać” 5 lat i gdyby nie powrót do narkotyków, to myślę, że mnie tu nie bytoby. [N.S. — 40 lat, żonaty, mieszkaniec dużego miasta, wykształcenie średnie, czterokrotny recydywista, wyroki skazujące za pobicie policjanta, napad rabunkowy, kradzieże].

Pomimo pozytywnych efektów terapii prowadzonej w zakładzie karnym, po zakończeniu kary izolacji i wyjściu na wolność, część uzależnionych ekswięźniów nie podejmuje dalszej terapii i powraca do nałogu wskutek kumulacji problemów związanych z próbami wpasowania się w ramy obowiązującego ładu społecznego. Brak umiejętności konstruktywnego radzenia sobie w sytuacjach trudnych oraz brak efektywnego wsparcia społecznego aktywują mechanizm uzależnienia i prowadzą do radzenia sobie w sposób przekraczający ramy prawne.

Po opuszczeniu zaktadu karnego potrzebowatem wsparcia finansowego i pracy. Oczekiwałem pomocy w podjęciu zatrudnienia. Ukończyłem kurs z funduszu europejskiego, którego ukończenie miało zapewnić mi pracę. Okazało się, że sa to „obiecanki cacanki, a głupiemu radość”. Nie załamałem sie jednak $i$ wszystko wziałem we własne ręce. I udało się! Znalazłem prace i znów miałem petna rodzinę. Przestatem pić, bo alkohol przyczynit się do popetniania przeze mnie przestępstw. Nie wytrzymywatem jednak kłopotów rodzinnych i za każdym razem szukatem ratunku w alkoholu. Traf chciat, że $w$ stanie upojenia alkoholowego na swojej drodze spotkatem podłego $i$ zawziętego osobnika, z którym dawniej miałem zatargi. Wyładowałem na nim moja złość, używając stów, no wiadomo jakich... uznali to za groźby karalne $i$ za to ponownie zostałem skazany. Teraz, $w$ więzieniu męczy mnie myśl, że mój wysitek powrotu do spoleczeństwa zostat zniweczony. A najbardziej to, że sam się do tego przyczyniłem. [W.K. - 54 lata, żonaty, mieszkaniec dużego miasta, wykształcenie zawodowe, trzykrotny recydywista, wyroki skazujące za kradzież i znieważenie funkcjonariusza publicznego]

Do przestępstwa powróciłem po opuszczeniu aresztu śledczego głównie dlatego, że potrzebowatem pieniędzy na narkotyki. Po częśsi czułem się też bezkarny. Wcześniej bylem już kilka razy karany, ale za każdym razem dostawatem wyrok w zawieszeniu. Pierwszy raz, po opuszczeniu aresztu 
śledczego, otrzymałem zapomogę $w$ wysokości 20 zt. Bytem w potrzebie finansowej, a kraść nie chciałem, więc oczekiwałem jakiegoś sensownego zasitku pieniężnego oraz pomocy w znalezieniu pracy. Zwróciłem się z tym do mojego kuratora. Na odpowiedź musiałem czekać przeszło tydzień i dostałem 250 złotych zapomogi, co miało mi wystarczyć na moje potrzeby do czasu, aż nie dostane pracy i pierwszej pensji. Kurator stwierdzit, że te 250 złotych musi mi wystarczyć, a prace to musze sobie sam znaleźć. Nie potrafitem sobie z tym wszystkim poradzić. Po pewnym czasie wrócilem do brania narkotyków i kradzieży, gdyż to byt najłatwiejszy sposób na zdobycie pieniędzy na życie. [L.N. - 37 lat, kawaler, mieszkaniec dużego miasta, wykształcenie podstawowe, jednokrotny recydywista, wyroki skazujące za niezapłacenie grzywny i kradzież]

Implikacją trudności w podjęciu zatrudnienia, braku środków na utrzymanie oraz uzależnień są między innymi utrata mieszkania i bezdomność. W najbardziej niekorzystnej sytuacji prowadzącej do bezdomności są skazani nieposiadający rodzin lub ich pozbawieni wskutek porzucenia przez rodzinę pochodzenia, rozwodu czy też odejścia konkubiny lub partnerki żyjącej z nimi w innej formie życia rodzinnego. Opuszczenie przez najbliższych w powiązaniu ze słabą konstrukcją psychiczną i negatywnymi skutkami pobytu w więzieniu, brakiem wsparcia oraz przyjmowaniem strategii unikowej w radzeniu sobie z problemami, to główne przyczyny utraty sensu życia, samoizolacji i bezdomności wielu ekswięźniów.

\section{Bezdomność}

W potocznym rozumieniu bezdomność jest stanem charakteryzującym się brakiem domu. Pojawiają się jednak problemy z wypracowaniem naukowej, spójnej i uniwersalnej definicji tego pojęcia. Najbardziej oddające istotę tego stanu są w moim odczuciu dwa ujęcia. Pierwsze traktuje bezdomność jako konieczność życiową osób niemających możliwości godnego zamieszkania, a jedynie szansę na tymczasowe schronienie w noclegowniach czy innych placówkach pomocy społecznej. W tym kontekście bezdomny jest osobą wyizolowaną i bezradną, która zerwała więzi z rodziną i wytworzyła mechanizm przystosowania do trudnych warunków, zmuszających ją do trwania w patologicznym stanie [Oliwa-Ciesielska 2004, s. 25]. Drugie, psychologiczne ujęcie bezdomności odnosi się do cech osobowościowych, które do niej prowadzą: wysoki poziom neurotyczności, niski poziom otwartości na doświadczenie, dominujący archetyp „Sieroty” lub „Męczennika”, niski poziom kontroli wewnętrznej, słabe ukształtowanie systemu wartości, redukcjonistyczny i niedojrzały stosunek do norm moralnych [Homik 2010, s. 4]. Oba przytoczone ujęcia w pełni opisują sytuację i psychologiczne uwarunkowania bezdomnych ekswięźniów.

Bezdomność jest zjawiskiem wielowymiarowym i dotyczy wszystkich sfer życia społecznego. Proces wchodzenia w bezdomność rozpoczyna się od załamania się programu życiowego [Stankiewicz 2002]. W przypadku byłych więźniów 
proces ten aktywowany jest skazaniem na karę izolacji. Po osadzeniu w zakładzie karnym następuje rozluźnienie, a często zerwanie więzi uczuciowych z rodziną i utrata mieszkania. Po wyjściu na wolność i nieudanej próbie readaptacji społecznej uruchamiane są mechanizmy obronne i życzeniowe sposoby myślenia. Gdy wszelkie próby powrotu ekswięźnia do normalności zawodzą, byłemu więźniowi pozostaje tylko całkowite odcięcie się od przeszłości. Kolejną fazą wchodzenia w bezdomność jest postępujące ubóstwo, redukcja potrzeb i oddalanie się od dawnego środowiska, po czym następuje etap uwewnętrznienia stanu bezdomności. Ekswięzień zaczyna poruszać się w świecie ludzi sobie podobnych, lokalizuje tymczasowe miejsca noclegowe i nabywa umiejętności bycia bezdomnym. W kolejnej fazie następuje proces przystosowania się do chronicznej sytuacji, po czym w fazie właściwej - ukształtowanie się tożsamości bezdomnego i internalizacja statusu osoby bezdomnej.

Bezdomność jest jednym z najbardziej dramatycznych problemów człowieka jej doświadczającego. $Z$ pojęciem tym wiążą się stereotypowe odniesienia do bycia bezdomnym, czyli bezrobotnym, leniwym, chorym, brudnym czy uzależnionym. Tak więc bezdomność jest piętnem, które dla bezdomnych ekswięźniów jest dodatkowym ciężarem, gdyż żyć muszą z podwójną etykietą — bezdomnego kryminalisty.

Odnosząc się do problemu bezdomności byłych więźniów, należy podkreślić, że niektórzy z nich świadomie rezygnują z prób ułożenia sobie życia na wolności, gdyż - jak twierdzą badani recydywiści — nie są w stanie ponownie zakorzenić się w środowisku wolnościowym. Nie umiejąc sprostać wymaganiom związanym z samodzielnym poszukiwaniem rozwiązań prowadzących do względnej stabilizacji życiowej, traktują więzienie jak dom, którego nie mają lub przystań, w której odpoczywają po trudnym, bezowocnym i często burzliwym pobycie na wolności.

Wrócitem do więzienia, ponieważ mam do spłacenia alimenty. Niby skąd mam wziać pieniadze, choćbym nawet chciat je spłacać? Nie posiadam środków do życia, pracy i domu też nie mam. $Z$ tego powodu notorycznie powracam do kryminału. Nie mam żadnej pomocy od rodziny, a także z instytucji, które jej powinny udzielać - Urzędu Pracy czy GOPS-u. Gdyby ktoś mnie na wolności wspart i pomógt w zakotwiczeniu się, to pewnie nie powróciłbym do zakładu karnego. Moja jedyna racjonalna myśla sa powroty do kryminatu. To tu mam zapewnione jedzenie, opiekę lekarska, wikt i opierunek. Sam na wolności nie umiem sobie poradzić i mimo tego, $\dot{z}$ e chciałbym żyć samodzielnie, to wiem, że następnym razem też będzie tak samo... [B.T. - 63 lata, żonaty, mieszkaniec wsi, wykształcenie podstawowe, jednokrotny recydywista, wyroki skazujące za uchylanie się od obowiązku alimentacyjnego i włóczęgostwo].

Mój powrót do przestępstwa byt po pierwsze spowodowany moja impulsywnościa i głupota, a po drugie brakiem mieszkania. Pomocy nie 
otrzymałem żadnej, ani od kuratorki, ani z sadu, ani z MOPS-u. Byłem zdany catkowicie sam na siebie, a do tego nie mam żadnej rodziny, no $i$ stało się tak, że przebywam w zakładzie karnym - tu mam tózko, dach nad glowa, prace i jest super. [B.N. — 46 lat, rozwiedziony, mieszkaniec dużego miasta, wykształcenie zawodowe, dwukrotny recydywista, wyroki skazujące za niespłacanie kredytu, pobicie i kradzieże]

W tym miejscu rezygnuję z wszelkich komentarzy. Niech przemówią krótkie fragmenty historii życia recydywistów, a zwłaszcza te momenty, które doprowadziły ich do stanu bezdomności.

Pierwszy raz, po opuszczeniu zakładu nie miałem dokad iść, ani do kogo wrócić. Moja była konkubina wymeldowała mnie z domu, w którym bytem zameldowany. Od tej pory bytem bez pracy, domu i wsparcia rodziny. $\mathrm{Na}$ wolności potrzebowatem jakiegokolwiek mieszkania, a także chociaż minimalnej pomocy finansowej, żeby już nie utrzymywać się z handlu prochami. Niestety, wszyscy wokót odsytali mnie ciagle w inne miejsca, rzekomo właściwe do udzielania pomocy. Rzekomo, bo gdy tylko tam się zwrócilem o pomoc, to piętrzyty się wymagania, a czas mijat... Mieszkatem u kumpla na działce, ale zima przyszła i wymięktem. Odszukatem dawnych znajomych $i$ znów wkręcitem się $w$ dilerkę. Tak sobie czasem myśle, że tak naprawdę, to bezpiecznie $i$ w miarę dobrze czuję się tylko $w$ więzieniu. Nie wiem co będzie, gdy odsiadka się skończy. Pewnie znów szybko tu wrócę... [W.K. - 37 lat, kawaler, mieszkaniec dużego miasta, wykształcenie zawodowe, jednokrotny recydywista, wyroki skazujące za handel narkotykami]

Dtugo odsiadywałem pierwszy wyrok. Po wyjściu z zakładu potrzebowatem pieniędzy oraz domu, gdzie mógłbym zamieszkać. W międzyczasie straciłem rodzine, przyjaciele gdzieś ,wyparowali”, a żadne instytucje nie zainteresowaty się moją sytuacja, w której znalazłem się po opuszczeniu zaktadu. Z pomocy postpenitencjarnej otrzymatem jedynie $100 \mathrm{zt}$ na dojazd do domu, którego oczywiście nie mam. Od lat już jestem bezdomny, bo nie stać mnie nawet na wynajęcie jakiejś komórki do spania $i$ ochrony przed deszczem, wiatrem czy mrozem. Dopuścilem się kradzie$\dot{z} y$, wtamatem się do cudzego domu, a dlaczego to zrobitem? Powód stary jak świat - brak kasy. [P.Ł. - 50 lat, rozwiedziony, mieszkaniec wsi, wykształcenie zawodowe, jednokrotny recydywista, wyroki skazujące za zabójstwo i kradzież z włamaniem]

Pierwszy raz po wyjściu z więzienia potrzebowatem na poczatek wsparcia pieniężnego w wysokości co najmniej 1000 złotych, no i jakiejśs nowej odzieży. Teraz z kolei, jak skończę odsiadkę, to nie mam gdzie wrócić, bo moja była żona mnie wymeldowała z mieszkania i z tego powodu będe potrzebować na wyjściu jakiegoś lokum. Obojętnie gdzie, bo wtedy od 
razu szukałbym pracy. Mieszkanie jest najważniejsze. Na rozruch tė̇ potrzebne sa pieniadze. Poprzednim razem nawet nie odebratem pieniędzy z kasy sądowej, które mi przyznano, bo tylko pięć osób w miesiącu kasa obstugiwata. Nie zdążytem w nastęnym miesiacu, bo mnie zapuszkowali [J.W. - 43 lata, rozwiedziony, mieszkaniec małego miasta, wykształcenie zawodowe, dwukrotny recydywista, wyroki skazujące za groźby karalne]

Mój przypadek jest dosyć skomplikowany, ponieważ 16 lat staram sie o mieszkanie. Jest to dla mnie poważny problem, gdyż nie mam już rodziny, pracy i domu, do którego można byłoby wrócić. Do popetnionych przestepstw oczywiście sam się przyczynitem, gdyz chcac utrzymać dom $i$ rodzinę, potrzebowatem zdecydowanie więcej środków finansowych niż można było zarobić uczciwie. [R.N. - 37 lat, rozwiedziony, mieszkaniec dużego miasta, wykształcenie zawodowe, jednokrotny recydywista, wyroki skazujące za kradzież, handel narkotykami i oszustwa finansowe]

Po wyjściu na wolność musiatem nocować po różnych znajomych, bo nie miałem do kogo i gdzie wrócić. Rozwiodtem się, a była żona nie chciała mnie znać... Dopiero po rozmowie z moja obecna narzeczona i jej matka po kilku miesiacach zamieszkatem u nich. Po roku otrzymatem wtasne mieszkanie, choć nie sądziłem, że będzie aż tak ciężko z tym całym załatwianiem. Do dzisiaj jestem wdzięczny matce mojej narzeczonej, że mnie przygarnęta jak wtasnego syna i naprawdę dużo jej zawdzięczam. Bytem na wolności 7 lat i gdybym dopilnowat jednej sprawy, na pewno teraz bym tu nie siedziat. Ale siedzę za nieplacenie alimentów. Nie mogę sobie wybaczyć, że tak się stało, ponieważ moja narzeczona pozostała sama z dwójka małych dzieci. Moi rodzice nie żyja, pochowatem ich będąc w więzieniu, no i teraz calym moim światem jest moja narzeczona. Mam rodzinę, której zawdzięczam, że tyle lat bytem na wolności i mam dla kogo żyć, bo tylko ich mam, tylko oni pomogli mi odnaleźć się po dlugim przebywaniu $w$ więzieniu. Dla mnie sa wszystkim i nic, ani nikt tego nie zmieni. Mam nadzieję, że szybko do nich wrócę. [H.T. - 37 lat, rozwiedziony, mieszkaniec miasta średniej wielkości, wykształcenie podstawowe, dwukrotny recydywista, wyroki skazujące, za rozbój, rozpijanie osoby małoletniej i uchylanie się od płacenia alimentów]

\section{Nikła pomoc instytucjonalna lub jej brak}

Z wypowiedzi osób badanych wynika, że skazani opuszczający polskie więzienia są pozostawieni sami sobie. Pomoc postpenitencjarna jest tak niewielka, że nie wystarcza na przetrwanie choćby kilku dni. Jest to sytuacja dramatyczna dla tych byłych więźniów, którzy nie posiadają rodziny, do której mogliby wrócić oraz pracy, dzięki której mogliby względnie egzystować. 
Po opuszczeniu zaktadu karnego najbardziej brakowało mi tego, że nie miatem gdzie wrócić i nie miat kto mi pomóc — brak mieszkania, brak pracy stałej, brak pomocy w taki sposób, żeby ktoś naprowadzit mnie na wtaściwy tor, jakieś wsparcie, np. ze strony pani kurator. I znów się zagubitem, wpadtem w znane mi wcześniej towarzystwo. Kumple mnie dowartościowali, poszliśmy kilka razy na włam, ale ja wpadtem, bo byłem glupi i przyszalatem ze zdobyta kasą. Ktoś mnie sypnąt i znów siedzę. [J.K. - 27 lat, kawaler, mieszkaniec dużego miasta, wykształcenie gimnazjalne, jednokrotny recydywista, wyroki skazujące za kradzież i kradzież z włamaniem]

Niektórzy z nich są świadomi własnej odpowiedzialności i nie winią innych za swój powrót do przestępczej działalności. Jedni dostrzegają swoje negatywne cechy charakteru, inni zaś impulsywność i skłonność do agresji. Osoby te mają wewnętrzną lokalizację kontroli i własną porażkę readaptacyjną przypisują sobie samym.

Po odbyciu pierwszego wyroku nie potrzebowatem żadnej pomocy ze strony państwa, gdyż po opuszczeniu zakładu mieszkałem u rodziców i pracowatem z ojcem na budowie (ojciec prowadzit swoja działalność gospodarcza). Ja mam zawód blacharz dekarz i w tym zawodzie zawsze znajde pracę. Po ślubie też pracowatem i nie potrzebowatem wsparcia ani od państwa, ani od rodziny. W moim przypadku przyczyna powrotu do zakładu karnego byt przypadek. Najpierw bójka (zabiłem człowieka), a później strach przed odpowiedzialnościa $i$ dlatego taki, a nie inny wyrok. Po prostu jestem nerwowy i szybko wpadam w szat. [R.L. — 40 lat, rozwiedziony, mieszkaniec wsi, wykształcenie zawodowe, jednokrotny recydywista, wyroki skazujące za kradzież i zabójstwo]

Po pierwszym wyroku i wyjściu na wolność potrzebowałem mieszkania lub funduszy na wynajęcie mieszkania, środków finansowych na wyżywienie oraz inne niezbędne rzeczy do życia, które mogtyby mi pomóc w utrzymaniu się przez pierwszy miesiac do otrzymania wypłaty. Zostałem jednak zostawiony sam sobie i topitem smutki $w$ alkoholu... Do popetnienia kolejnych przestępstw skłoniła mnie własna głupota i nie mogę mieć o to do nikogo pretensji. [J.M. — 34 lata, kawaler, mieszkaniec miasta średniej wielkości, wykształcenie średnie, dwukrotny recydywista, wyroki skazujące za prowadzenie pojazdu w stanie nietrzeźwości oraz bez uprawnień]

Część rozmówców wskazywała nie tylko na brak wsparcia społecznego, ale także na brak zainteresowania administracji więziennej problemami osadzonych, zwłaszcza związanymi z kontaktem z rodzinami. Jak podkreślali, jest on najczęściej utrudniony z uwagi na:

- zwykle dużą odległość miejsca osadzenia skazanego od miejsca jego zamieszkania; 
- wysokie koszty podróży członków rodziny, zwłaszcza w sytuacji, gdy rodzina nie posiada wystarczającego zabezpieczenia finansowego i niejednokrotnie utrzymuje się tylko z zasiłków pomocy społecznej;

- brak kart telefonicznych, z których korzystanie pomogłoby osadzonym w podtrzymywaniu kontaktu z rodziną, a zwłaszcza z dziećmi;

- nieregularne i często sporadyczne wizyty członków rodzin w więzieniu wynikające między innymi z osłabienia więzi wewnątrzrodzinnych, a w przypadku więźniów długoterminowych ich powolnego zaniku.

Gdy po raz pierwszy wyszedtem po odsiadce na wolność, moim priorytetem byto znalezienie dobrej, płatnej pracy i założenie rodziny. Niestety $z$ biura do biura bytem odsytany z kwitkiem. Rosto zadtużenie zwiazane $z$ moim pobytem $w$ zaktadzie karnym [...] Ludzie po kilkanaście lat przesiaduja w zakładzie karnym bez pracy, a na wyjście dostaja 100-150 zt. Wystarczy to tylko na dojazd do domu, jeżeli go w ogóle mają. Większość recydywistów jest bez rodziny lub pochodzi z rozbitych rodzin. W więzieniu nikt nie interesuje się, czy skazany ma kartę telefoniczna, by mógt za$d z$ wonić i polepszyć i tak nadszarpnięte relacje z rodzina. Chciałbym żyć normalnie, ale nie widze perspektyw $w$ Polsce, aby w najbliższych latach coś się zmieniło na lepsze dla bytych więźniów. Przez ostatnie lata dużo czytałem o resocjalizacji w państwach Unii Europejskiej. Ostatnio w tygodniku sportowym przeczytatem tez artykut o Zlatanie Ibrahimowiczu, który $w$ młodości kradt $w$ swoim mieście rowery. Właścicielka zakładu samochodowego zatrudniła go i innych byłych więźniów też. A w Polsce kto zatrudni kryminalistę? W pewnym momencie zabrakło mi pieniędzy na życie, bytem zdesperowany i liczyłem na szybki zarobek, ale się przeliczyłem, więc znów znalazłem się w tym miejscu. Staram się nikogo nie obarczać wina za moje pobyty $w$ więzieniu. [R.T. - 34 lata, kawaler, mieszkaniec małego miasta, wykształcenie zawodowe, dwukrotny recydywista, wyroki skazujące za rozpijanie osoby małoletniej i rozbój]

Badani podkreślali także brak zainteresowania instytucji pomocowych trudną sytuacją pozostawionych na wolności rodzin, które borykają się nie tylko z problemami finansowymi, ale także emocjonalnymi, zdrowotnymi czy opiekuńczo-wychowawczymi. Nieobecność ojca skutkuje znacznym osłabieniem jego wpływów rodzicielskich i jest często przyczyną wikłania się dzieci w różnego rodzaju sytuacje ryzykowne. Wejście na ścieżkę niedostosowania społecznego dziecka osoby odbywającej karę izolacji więziennej może być podstawą negatywnej prognozy w zakresie przenoszenia wzorca rodzinnego w dorosłe życie.

$\mathrm{Z}$ analizy wypowiedzi osób badanych wynika, że rodziny badanych recydywistów nie są objęte wsparciem społecznym z uwagi na dotykający ich problem i jego negatywne implikacje. Brak systemu wsparcia i pomocy dla rodzin z problemem penitencjarnym rodzi poważne konsekwencje w postaci ich powolnej dezintegracji. 
Nie wierzę $w$ żadna pomoc społeczną. Skorzystałem już raz z takiej pomocy. Dostatem na zagospodarowanie i ubranie 30 ztotych. Więcej byto $z$ tym zachodu i ponizienia oraz pytań do mnie od pań, które robily wywiad. A dlaczego ponownie popetnitem przestępstwo? No cóż... dreszczyk emocji, rutyna i frajda na całego! (śmiech). [B.W. - 58 lat, rozwiedziony, mieszkaniec dużego miasta, wykształcenie zawodowe, jednokrotny recydywista, wyroki skazujące za kradzieże]

Mój pierwszy pobyt $w$ więzieniu byt od 1992 r. do 1994 i kolejne dwa do 2010 r. za drobne kradzieże. Wcześniej nikt oprócz mojej mamy, babci, cioci oraz dziadka mi nie pomógt. Ani zakład karny, ani instytucje na wolności. Choruję 40 lat na astmę oskrzelowa. Po moich pobytach, choć krótkich, musiatem ratować własne życie w szpitalach. Od 2010 do teraz przesiedziatem 7 lat. Czuje się niewinny. Wie o tym moja matka, która mnie wspiera. Staram się, nie myśleć źle i być optymistycznie nastawiony. Babcia i moja mama to sa najbliższe osoby, które mi zostały. Babcia ma 90 lat, a mama utrzymuje dom z najniższej emerytury. Adwokat wzią 7000 zł i mnie nie wybronit. Żaden kurator nie pomógł w znalezieniu pracy. [P.K. - 44 lata, kawaler, mieszkaniec dużego miasta, wykształcenie podstawowe, trzykrotny recydywista, wyroki skazujące za zmuszanie do uprawiania prostytucji, kradzieże i zabójstwo]

Przy opuszczeniu Aresztu Śledczego w Gdańsku dostałem 50 złotych. Nikt mnie nie poinformowat, że mogę starać się o pieniadze, których i tak bytoby tyle co nic. W moim zawodzie, czyli mechanika, gdy stysza , skazany”, to zaraz mówia, że nie maja pracy. Dostatem 200 złotych od państwa na start, to bytem zmuszony iść kraść, bo za co miatem żyć? Może miatem ze śmietników wyjadać resztki? Doszly do tego także opłaty za wynajem mieszkania oraz inne opłaty z tym zwiazane. System zakłada, że rodziny skazanych przyjma ich po opuszczeniu zakładu karnego, ale jest $w$ błędzie $i$ to wielkim. Ja mam rodzine, ale przez to, że jestem chory ide pod most, bo państwo ma mnie gdzieś. Zadam krótkie pytanie: gdzie sq kuratorzy, ludzie którzy powinni nam pomagać? Dlaczego wychowawcy w zakładzie nie mówia o różnych akcjach pomocowych i miejscach, gdzie możemy znaleźć pomoc w środowisku, do którego wracamy? Można wymieniać wiele błędów, które popetniaja obydwie strony, więc pomóżmy sobie nawzajem. Ja chętnie porozmawiam na ten temat. [M.M. - 28 lat, kawaler, mieszkaniec dużego miasta, wykształcenie zawodowe, jednokrotny recydywista, wyroki skazujące za rozboje]

Zdarzały się także wypowiedzi cedujące odpowiedzialność za własne niepowodzenie readaptacyjne na osoby bliskie, ich ułomności czy stany chorobowe. $\mathrm{W}$ rozmowach $\mathrm{z}$ badanymi niejednokrotnie pojawiał się żal za brak akceptacji ze strony rodziców czy partnerki życiowej, za ich ciągłe utyskiwanie 
i krytykowanie. Czasem też takie frustrujące sytuacje podsycane były poważnymi brakami finansowymi i niemożnością uzyskania pomocy społecznej.

Tym, co skloniło mnie do ponownego popetnienia przestępstwa po wyjściu $z$ więzienia, byta trudna sytuacja finansowa, która miałem, gdy zamieszkatem wraz z konkubina, a zarazem depresja byłej konkubiny, która miała duży wpływ na mój powrót do przestępstwa. Można powiedzieć, że przyczyna mojego powrotu do przestępstwa $w$ dużym stopniu była konkubina. Często bywato tak, że aby odstresować swoje nerwy, szedtem albo wypić alkohol lub kraść, bo to mnie uspokajato. Jeżeli chodzi o potrzeby, jakie miałem po opuszczeniu zakładu karnego, to jedynie fundusze, z których mógłbym przeżyć chociaż miesiąc, założenie własnej rodziny i ustatkowanie się. Niestety, rodzina mnie krytykowata we wszystkim, co tylko zrobiłem. Nie miatem też wsparcia i zrozumienia społecznego — byta jedynie krytyka. Pieniędzy na przeżycie zabrakło, a jedyna pomoca, która otrzymatem, byty talony na żywność i to była jednorazowa pomoc. [B.K. - 36 lat, kawaler/ konkubent, mieszkaniec miasta średniej wielkości, wykształcenie zawodowe, dwukrotny recydywista, wyroki skazujące za kradzieże i rozbój]

Po wyjściu na wolność szukałem pracy, ale nic nie znalazłem, więc poszedtem do sadu oraz do kuratorki. Nie uzyskałem żadnej pomocy pieniężnej ani żadnych talonów. Z opieki spotecznej również byta odmowa. W fundacjach $i$ stowarzyszeniach nie próbowatem, więc się nie wypowiadam. Jedynie co można byto prawnie załatwić to ubezpieczenie przez Urzad Pracy. W systemie pomocy dobrze bytoby wprowadzić talony żywnościowe na jakąs konkretna kwotę i bilety MZK czy PKP, chociaż na konkretny okres (miesiac, dwa) za okazaniem zwolnienia z aresztu. Również zakład karny mógtby przy wyjściu zaoferować jakaśs sensowna kwotę na przeżycie przynajmniej przez 2 miesiace, a nie 100 złotych na bilet. [K.C. - 35 lat, kawaler, mieszkaniec dużego miasta, wykształcenie zawodowe, dwukrotny recydywista, wyroki skazujące za kradzież, pobicie i rozbój]

Wśród badanych recydywistów byli także malkontenci, upatrujący źródeł porażki readaptacyjnej w każdym aspekcie swojego funkcjonowania zarówno na wolności, jak i w więzieniu. Przejawiali oni postawy roszczeniowe wobec systemu pomocy społecznej oraz zrzucali odpowiedzialność za swoje niepowodzenia na inne osoby i okoliczności, nie dostrzegając własnych ułomności, skłonności czy negatywnych cech charakteru. W takich przypadkach symptomatyczne było artykułowanie negatywnych emocji i kierowanie roszczeń wobec administracji więziennej lub instytucji lokalnych niosących pomoc i wsparcie osobom znajdującym się w sytuacjach trudnych i wykazujących znamiona kryzysu.

Wcześniej, jak wyszedtem z sankcji, to kurde nie poszedtem do pracy, tylko chciatem na narkotykach zarobić, ale się nie udało. Później chodziłem do pracy, no i myśle, że to przez sytuacje materialna tu wyladowatem. 
Jak to się mówi, chciatem szybko zarobić dużo pieniędzy. I teraz miatem taki niefart, że poszedtem kupić papierosy na osiedlu. Tam handlowat taki jeden facet papierosami i piwem i jakoś doszło do sprzeczki między nami $i$ uderzytem go. Akurat tak upadt, że w ptytki chodnikowe uderzyt i umart. No teraz to myślę, że to jakiś pech mnie prześladowat. Siedziałem najpierw pót roku, później dwa lata dostałem niestusznie, no i teraz to pobicie ze skutkiem śmiertelnym... tak jakoś wszystko się ułożyło dla mnie pechowo. Człowiek nie chciat, aż tak zrobić, ale wyszło jak wyszło. Teraz trzeba tutaj jakoś wytrzymać. [H.K. — 45 lat, rozwiedziony, mieszkaniec dużego miasta, wykształcenie zawodowe, dwukrotny recydywista, wyroki skazujące za kradzieże i rozbój]

Wśród osób badanych byli też i tacy recydywiści, którzy przyznawali się do ponownego wejścia w lokalne struktury przestępcze po wyjściu z więzienia. Jak twierdzili, nawet gdy chcieli odciąć się od patogennego środowiska, to nie mając stabilnego umocowania środowiskowego (brak pracy, rodziny, mieszkania) oraz wsparcia społecznego, mogli liczyć jedynie na dawnych znajomych. W kontakcie z nimi zaspokajali nie tylko potrzeby związane z zabezpieczeniem finansowym czy mieszkaniowym, ale także potrzeby emocjonalne, głównie przynależności i szacunku. Badani z goryczą wspominali nie tylko swoje doświadczenia związane $\mathrm{z}$ nieudanymi próbami wpasowania się w życie społeczne, ale także negatywne reakcje osób poprawnie funkcjonujących na informację o ich pobycie w więzieniu. Odrzuceni przez społeczność lokalną lub doświadczający jej obojętności, wracali do dawnego, przestępczego środowiska. Nękające ich problemy uśmierzali alkoholem lub narkotykami i w krótkim czasie ponownie popełniali czyny przestępcze.

Uległem namowom kolegów, bo zawsze obracatem się w takim towarzystwie, które przez życie szło na skróty. Gdy poszedtem po rozum do głowy $i$ wziatem sie za prace, to zmienitem towarzystwo. Poznatem ludzi normalnych i zaniechatem haniebnego procederu. Obecnie odsiaduje kare z 2010 roku. Przed osadzeniem pracowatem $w$ firmie o uznanej marce i po wyjściu mam zamiar wrócić do pracy i konkubiny. [I.S. - 32 lata, kawaler, mieszkaniec dużego miasta, wykształcenie podstawowe, jednokrotny recydywista, wyroki skazujące za kradzieże $\mathrm{z}$ włamaniem]

Po opuszczeniu zakładu karnego (chociaż siedziałem pierwszym wyrokiem tylko miesiac), oczekiwatem od moich bliskich zrozumienia, zaufania i żeby mnie wspierali w zlych chwilach. Oczekiwatem takze od ludzi, by przyjeto mnie do jakiejkolwiek pracy, bym mógt jakoś normalnie funkcjonować w spoleczeństwie. Te moje oczekiwania się spetnity, ale niestety za późno... Znalaztem pracę $w$ zakładach mięsnych na dwa tygodnie przed pójściem do zakładu karnego. Wszystko na darmo, ale próbowatem. Do kolejnego popetnionego przeze mnie przestęstwa przyczynito się glównie naduzywanie alkoholu i grono moich , starych" znajomych. [R.R. — 24 lata, 
kawaler, mieszkaniec miasta średniej wielkości, wykształcenie zawodowe, jednokrotny recydywista, wyroki skazujące za rozbój oraz naruszenie nietykalności cielesnej funkcjonariusza publicznego]

Recydywiści obarczali winą za własne niepowodzenie życiowe także system penitencjarny, odnosząc się do braku skutecznych programów resocjalizacyjnych, niewłaściwego doboru miejsca i sposobu odbywania kary, a także patogennego rozlokowywania skazanych w celach mieszkalnych. Z wypowiedzi badanych wyłania się także obraz niedostatecznego przygotowania osadzonych do ponownego funkcjonowania w warunkach wolnościowych. Przede wszystkim wskazywali oni na sporadyczne diagnozowanie potrzeb osadzonych, których zaspokojenie jest warunkiem koniecznym do podejmowania przez nich samodzielnych wysiłków readaptacyjnych. Narzekali, że działania podejmowane w tym zakresie przez Służbę Więzienną są sztampowe, niewystarczające i niedostosowane do indywidualnych potrzeb osób skazanych, a zwłaszcza potrzeb więźniów długoterminowych, którzy po zakończeniu kary izolacji muszą wpasować się w społeczność żyjącą w dynamicznie zmieniającej się i nieznanej im rzeczywistości. Zdarzały się wypowiedzi osób świadomych konieczności utworzenia sieci ośrodków readaptacyjnych w taki sposób, by każdy ekswięzień powracający do środowiska wolnościowego mógł otrzymać pomoc i wsparcie z różnych źródeł, a przede wszystkim pomoc w zakresie podstawowym - pozyskania zatrudnienia i mieszkania oraz naprawy nadwątlonych więzi z rodziną.

Główna przyczyna mojego powrotu do przestepstwa byt brak przygotowania do warunków wolnościowych, złe funkcjonowanie administracji więziennej, brak opieki psychologicznej, uniemożliwienie kontaktu bezpośredniego z bliskimi, brak zrozumienia moich potrzeb, brak środków do życia, brak pracy. Nie otrzymatem żadnej pomocy od państwa, a kuratora nie interesuja warunki bytowe skazanego, tylko jego zobowiąznia wobec państwa (spłata grzywny, zadośćuczynienie itd.). Moja kolejna odsiadka nie nauczyła mnie niczego innego jak nienawiści do urzędników. [L.J. - 35 lat, kawaler, mieszkaniec małego miasta, wykształcenie średnie, jednokrotny recydywista, wyroki skazujące za kradzież i udział w zorganizowanej grupie przestępczej]

Bez zaplecza finansowego, zwalniany więzień skazany jest na pomoc bliskich lub pomocy spolecznej, a często nie posiada rodziny ani uprawnień do pomocy spolecznej. Pobyt w noclegowniach, schroniskach czy hostelach nie rozwiazuje problemu, gdyż przesycone sq one ludźmi z marginesu, obciążonymi patologiami. Równie ważna jest możliwość zamieszkania we własnym lokalu, bez możliwości powrotu do dawnego środowiska. Po wieloletnich wyrokach nie istnieje $w$ polskim systemie realna możliwość, by dlugoterminowi ułożyli sobie życie na wolności. Ludzie opuszczaja więzienia oderwani od rzeczywistości. Bardzo istotny jest brak wiedzy 
i motywacji do starania się o warunkowe zwolnienie. Przepisy sa niejasne, a skazani nie wiedza, jak naprawdę dażyć do tego celu i nie wierza w jego otrzymanie na skutek pracy nad soba [...] Brak jest prawdziwej selekcji $w$ doborze skazanych do miejsca i sposobu odbywania kary. Skazani za przestępstwa bez przemocy odbywaja kary z przestepcami agresywnymi. Zwykli musza odbywać kary z podkulturowcami. To nie wptywa dobrze na ich resocjalizację. Przygotowanie do wyjścia skazanych na wolność w zakładzie karnym jest nieefektywne. Ucza nas, jak pisać CV, jak poruszać się po Internecie i takich tam umiejętności społecznych, z którymi większość z nas nie ma problemu. Zwtaszcza wobec dtugoterminowych, trzeba dziatania dostosować do ich potrzeb. Trzeba zapewnić im pomoc finansowa, pomóc uzyskać jakiś lokal socjalny, uczyć dobrych relacji $z$ rodzina. W końcówce odbywania kary lub przed spodziewanym warunkowym zwolnieniem trzeba ich wprowadzić $w$ to środowisko, $w$ którym żyja na wolności. [T.W. - 45 lat, rozwiedziony, mieszkaniec dużego miasta, wykształcenie średnie, dwukrotny recydywista, wyroki skazujące za kradzieże]

Zdarzały się także refleksje dotyczące pobytu w więzieniach na terenie innych państw i porównywanie warunków w nich panujących oraz traktowania osadzonych z sytuacją aktualnie doświadczaną i polskim systemem penitencjarnym.

Pierwsze przestępstwo popetniłem w młodym wieku jako człowiek jeszcze nieuksztaltowany. Zostato ono dokonane pod wptywem środowiska oraz z przyczyn materialnych. $W$ domu byla bieda, a w prawie byly luki stwarzające możliwość dokonywania czynów przestępczych przynoszacych duże zyski bez praktycznie żadnych konsekwencji. Gdy opuściłem pierwszy raz zaktad karny, zostałem pozostawiony samemu sobie. Administracja więzienna nie interesowata się, dlaczego popetnitem przestępstwo pomimo młodego wieku. Wówczas nie istniały programy resocjalizacyjne, a ja wychodzac z więzienia, nie otrzymatem żadnej pomocy, czy to finansowej, czy mentalnej. Wrócilem do miejsca zamieszkania, gdzie jedyna pomocna dłoń podali mi znajomi ze środowiska przestępczego. Oni potrafili mi pokazać jakieś cele, i choć byty one zwiazane z popetnianiem przestępstw, to dla mnie, wówczas młodego człowieka, były atrakcyjne nie tylko dlatego, że skoki przynosity kasę, ale również podnosity moje ego. Poza przechowaniem mnie $w$ więzieniu system nie dat mi nic poza poczuciem, że jestem obywatelem drugiej kategorii, bo jestem już karany. W trakcie odbywania kary nie udzielono mi żadnej przepustki, nie otrzymatem warunkowego zwolnienia, a mój pobyt $w$ więzieniu można określić jako odwieszenie płaszcza do szatni $i$ wydanie go na koniec kary. Nie mając rodziny, która mogłaby być dla mnie największym motywatorem, trudno mi było żyć zgodnie z normami. Potrzebowatem odcięcia od środowiska, z którego pochodzitem, postawienia nowych celów życiowych, powolnego wdrożenia 
$w$ życie. Nie otrzymawszy tego, wrócilem do przestępstw, a więzienie sprzyjało zawieraniu nowych znajomości. Uważam, że gdyby w młodości $w$ więzieniu i po wyjśsciu z niego ktoś sprawowat odpowiedniq kuratele nade mna, gdyby pomógł mi w ukierunkowaniu własnych zdolności, nie wrócitbym do przestępstwa i żyłbym w zgodzie z otoczeniem. Bez wzorców $i$ celów $w \dot{z} y c i u$, po pobycie $w$ więzieniu $i$ oddany środowisku, z którego się wywodzitem, nadal szedtem droga przestępcza [...] Pyta Pani, jakiego wsparcia należy udzielać osobom skazanym $w$ trakcie pobytu $w$ więzieniu i po wyjściu na wolność? W więzieniu, to przede wszystkim zastosowania programów resocjalizacyjnych dostosowanych do ich potrzeb, a nie pozorujących resocjalizację oraz traktowania więźniów na zasadach niebudzacych w nich poczucia niższości, bo poniżanie człowieka zawsze rodzi agresję lub poczucie odrzucenia przez społeczeństwo. Uważam, że model skandynawski jest najodpowiedniejszy, gdzie skazanego poddaje się opiece personalnej, zna się jego problemy, przeszłość i stara się im przeciwdziałać w przyszłości. Tego nie ma niestety w polskim systemie. Może na skutek zbyt dużej liczby skazanych lub naleciałości z poprzedniej epoki, które sa mocno zakorzenione. W Szwecji też siedziatem w więzieniu $i$ bytem poddany spersonalizowanemu programowi resocjalizacyjnemu. Przeszedtem na przyktad program ,Stop kryminalnemu myśleniu”, o którym nigdy nie słyszałem $w$ polskim więzieniu. Wówczas miatem jeszcze rodzinę i to ona była moja motywacja do tego, aby juz nie wrócić na droge przestępstwa. Ale wróciłem... Co przyczynito się do tego, że znów to zrobilem? Wszystko po trochu - środowisko, w którym się wychowatem, $i$ które chętnie przygarniato wychodzacych z kryminatu, chciwość, brak perspektyw, odrzucenie przez spoleczeństwo, przez które bytem zawsze traktowany jak obywatel drugiej kategorii. Poza tym podczas ostatniego pobytu na wolności utraciłem rodzinę. Odeszła ode mnie kobieta z synem i założyła nowa rodzinę. Nie winie jej za to, że chciała stworzyć normalna rodzinę, ale w ten sposób oraz na skutek dtugiego pobytu w więzieniu, bez przepustek i z dwoma godzinami widzeń w miesiacu utraciłem sens życia i znowu pozostało mi jedno środowisko i materialistyczne podejście do $\dot{z y c i a}$. [M.N. - 40 lat, kawaler, mieszkaniec dużego miasta, wykształcenie średnie, trzykrotny recydywista, wyroki skazujące za fałszowanie dokumentów, zmuszanie do uprawiania prostytucji, handel narkotykami]

Po opuszczeniu zakładu jedyne co w miarę szybko udało mi się zorganizować, to kat do spania u kumpla. Z praca byto dużo ciężej, ponieważ pracodawcy niechętnie zatrudniają bytych skazańców. Myślę sobie, że jako osoba negatywnie doświadczona w próbach powrotu do spoleczeństwa, wiem, co można by zmienić, aby byli więźniowie nie byli przymuszeni do popetniania kolejnych przestępstw. Dobrze by było, żeby było więcej organizacji, które pomagatyby osobom opuszczajacym zaktady karne w znalezieniu pracy. Wiem, że tym w Polsce zajmuje się tylko fundacja ,Stawek" i chyba jeszcze 
jakieś dwie inne. Przydatoby się także zmienić system przyznawania lokali socjalnych. Ale najważniejsze jest to, aby w każdym, nawet małym mieście byty ośrodki, które zajmowatyby się rozpatrywaniem indywidualnych potrzeb bytych więźniów i organizowaniem im pomocy. [A.D. - 39 lat, rozwiedziony, mieszkaniec dużego miasta, wykształcenie wyższe, dwukrotny recydywista, wszystkie wyroki skazujące za kradzieże]

Cytowane wypowiedzi recydywistów ugruntowują moje przekonanie o możliwości włączenia do działań ukierunkowanych na projektowanie pomocy i wsparcia penitencjarnego oraz postpenitencjarnego tych byłych więźniów, którzy pomyślnie przeszli proces readaptacji i reintegracji społecznej. Opisywane przez badanych perypetie życiowe są świadectwem zarówno ich niedostatków kompetencyjnych, popełnianych błędów, ułomności środowisk rodzinnych, obojętności społeczności lokalnych, jak i niesprawności instytucji pomocowych i samorządowych. W tonie wszystkich wypowiedzi przebija poczucie braku skuteczności własnej i systemowej oraz bolesna świadomość porażki życiowej.

Narracje recydywistów wyraźnie wskazują na kaskadowe pojawianie się problemów aktywujących mechanizm bezdomności i powrotności do przestępstwa. Każdy nierozwiązany problem stanowi odrębny czynnik ryzyka, który w dłuższej perspektywie może sam lub we współdziałaniu z innymi czynnikami doprowadzić do alienacji społecznej i wykluczenia. Szczególnie patogenne są: defaworyzacja byłych więźniów na rynku pracy, niski poziom wykształcenia i przygotowania zawodowego, głębokie deficyty kompetencyjne, odrzucające postawy pracodawców, niekorzystne cechy środowiska życia i/lub brak wsparcia ze strony rodziny, wpływy środowiska przestępczego, trudności w przystosowaniu się do życia na wolności wynikające z nieskorygowanych zaburzeń zachowania, cech osobowościowych, negatywnych skutków izolacji więziennej oraz skłonności do uzależnień.

\subsection{Wizja życia po wyjściu na wolność...}

Badani recydywiści budowali swoją wizję „uzdrowienia” sytuacji ekswięźniów na własnych, minionych doświadczeniach związanych z próbami ułożenia sobie życia na wolności. Dokonując retrospekcji, próbowali formułować uogólnienia i wizualizować. Wskazywali na trudności wynikające z wcześniejszych powiązań ze światem przestępczym, silnego poczucia odrzucenia przez społeczeństwo, z braku wsparcia i środków do życia, utraty rodziny, a także z własnych cech charakteru, które ponownie wiodły ich na kryminalną ścieżkę. Podkreślali, że jedyną ostoją byli dla nich dawni znajomi, od których wpływu rozpoczynała się ich kariera przestępcza. Snuli jednak wizje, w których przewija się element związany z koniecznością odizolowania się od poprzedniego środowiska 
przestępczego, traktując to jako warunek konieczny do podjęcia wysiłków ukierunkowanych na zmianę dotychczasowego, przestępczego stylu życia.

Ja mam swoje plany zwiąane z normalnym wyjściem teraz i uważam, że to przejdzie, że już nie będę siedziat. Ojciec sam powiedziat, że sam postara się dużo pomóc, mam przyjaciótki różne, co też chca pomóc, mam przyjaciót, co też prowadza działalności gospodarcze i idę w tym kierunku. Priorytet mój, to sprzedanie mieszkania na Pradze i wyprowadzam się z Pragi. To jest mój priorytet. Powiedziatem - odcinam się od tego towarzystwa, jak najdalej. Mój bład, bo mieszkatem też na Jelonkach, na Bemowie, tam też mieszkanie miatem swoje, ale ciagnęło mnie do moich terenów. Teraz żałuję. Teraz bym wrócit na Jelonki. Tam miałem ciszę, spokój. Teraz też zamierzam się odizolować od tej Pragi i od tego Grochowa, tego mojego towarzystwa i założyć działalność gospodarcza i żyć po prostu normalnie. Pomóc rodzinie trochę. [D.Z. - 35 lat, kawaler, mieszkaniec dużego miasta, wykształcenie zawodowe, recydywista wielokrotny, wyroki skazujące za kradzieże]

Posiadanie rodziny jest ważne dla zdecydowanej większości skazanych, zarówno dla kawalerów, jak i osób rozwiedzionych. W wizji życia rodzinnego po wyjściu na wolność centralne miejsce zajmują dzieci. Pragnienie ich posiadania deklarowali najczęściej młodzi recydywiści stanu wolnego posiadający najczęściej gimnazjalny poziom wykształcenia. Wypowiedzi ich świadczą o budzącej się refleksji nad samotnym przeżywaniem uwięzienia wraz z perspektywą powrotu do... pustego, „zimnego” domu lub jego utraty i bezdomności. Niektóre wypowiedzi świadczyły o planowaniu życia w postaci nierealnych do spełnienia wizji lub wręcz marzeń.

Żałuje, no bo szkoda lat siedzenia, zmarnowanych lat życia. Przede wszystkim chce mieć swoja rodzine, żeby mieć zajęcie, pracę. Na pewno gdybym miat stała prace, to by mi to ułatwiło znalezienie fajnej dziewczyny, z która miałbym gromadkę dzieciaków. Żadnych kolegów, żadnego złego towarzystwa. Najważniejsza jest rodzina. [I.S. — 32 lata, kawaler, mieszkaniec dużego miasta, wykształcenie podstawowe, jednokrotny recydywista, wyroki skazujące za kradzieże $\mathrm{z}$ włamaniem]

Recydywiści młodzi i stanu wolnego częściej niż pozostali myślą o posiadaniu licznego potomstwa. Oprócz naturalnej potrzeby wynikającej z możliwości prokreacyjnych determinowanych wiekiem, artykulacja potrzeby tego rodzaju może wynikać z tęsknoty za stabilizacją, ciepłem domowym lub też z pragnienia przeżywania na nowo wrażeń i emocji doświadczanych w dzieciństwie - tym razem w roli rodzica kompensującego własne potrzeby emocjonalne. Wydaje się to powiązane z naszkicowanymi przez większość badanych recydywistów obrazami szczęśliwego i beztroskiego dzieciństwa. Szczęśliwego, pomimo rodzinnych dysfunkcji, problemów i trudności dnia codziennego. Dodatkową motywacją są relacje z partnerkami. Badani są świadomi tego, że ich związki 
przechodzą próbę czasu i są wielowątkowo zagrożone. Nie chcą samotnie iść przez życie. Chcą być kochani i innym potrzebni.

Ja chciałbym swojemu dziecko zapewnić wszystko to, czego ja nie miałem. Żeby nie czuło się nigdy gorsze. Żeby moja narzeczona miała fajne rzeczy. Staram się dla nich robić jak najlepiej. Ja poprzednio, po wyjściu z paki, pracowatem normalnie, nie byto z tego jakiś dużych pieniędzy, ale pracowatem normalnie. Teraz to mam ostatnia szasne, żeby się zmienić. Moja narzeczona też nie będzie czekała wieki. [J.W. - 29 lat, kawaler, mieszkaniec dużego miasta, wykształcenie średnie, dwukrotny recydywista, wyroki skazujące za oszustwa, handel narkotykami i rozbój]

Myślę, że tym, co może sprawić, że już tu nie wróce, jest całkowita zmiana mojego dotychczasowego życia... Muszę założyć rodzinę, znaleźć dobrze płatna pracę i zaczać coś znaczyć, być komuś potrzebnym i dla kogoś ważnym. Myślę, że to zmieniłoby moje podejście do życia. [K.C. — 35 lat, kawaler, mieszkaniec dużego miasta, wykształcenie zawodowe, dwukrotny recydywista, wyroki skazujące za kradzież, pobicie i rozbój]

Symptomatyczny wydaje się również wynik badania wskazujący, że najstarsi recydywiści częściej niż osoby z pozostałych kategorii wiekowych nie są zainteresowani poziomem wykształcenia swoich dzieci. Być może jest to spowodowane tym, że większość recydywistów po 50 rż. posiada wykształcenie podstawowe, a zatem edukacja nie jest dla nich wartością priorytetową. Należy także brać pod uwagę, że w większości przypadków ich dzieci są już dorosłe i zakończyły swoje kariery edukacyjne. Wynik ten otwiera pole do dalszych, pogłębionych penetracji empirycznych.

Plany związane z polepszeniem warunków finansowych i bytowych własnych oraz rodziny są w sposób istotny powiązane z miejscem zamieszkania osób badanych — im większe jest środowisko zamieszkania, tym częściej deklarowana jest potrzeba związana z poprawą sytuacji materialnej rodziny. Jest to podyktowane zapewne większymi kosztami utrzymania w dużych miastach niż w mniejszych ośrodkach, a przede wszystkim na wsi. $Z$ kolei wizja posiadania na wolności dobrze płatnej pracy zależna jest od wieku osób badanych — im młodszy jest recydywista, tym jest bardziej zmotywowany do poszukiwania zatrudnienia oferującego wysokie dochody.

Niezależnie od statusu związków rodzinnych, większość recydywistów młodych oraz $\mathrm{w}$ średnim wieku posiada nieletnie dzieci, które wymagają nie tylko matczynej opieki, ale również wsparcia finansowego od swoich ojców. Na wielu z nich ciąży obowiązek alimentacyjny, z którego muszą się wywiązywać, stąd też bardziej intensyfikują swoje wysiłki ukierunkowane na poszukiwanie pracy po zakończeniu kary izolacji więziennej.

Na chwile obecna najważniejszy jest dla mnie powrót do życia, jakie miatem przed osadzeniem, czyli rodzina, stała praca, która pozwalała mi na 
godne życie, zaspokajanie jakichś tam swoich zachcianek. Na dzień dzisiejszy liczy się dla mnie najbardziej moja rodzina. Bardzo nie chce ich stracić i jestem więcej niż pewien, że nigdy więcej nie trafię do pudta, mam zbyt wiele do stracenia. Wiele chwil $i$ tak juz minęto bezpowrotnie, nie da się tego zmienić, chwile z dziećmi, moje lata młodości... Niepotrzebnie zmarnowatem tyle życia, ale człowiek głupi po szkodzie. Gdybym mógt cofnać czas, na pewno postuchatbym rad mamy, ale wtedy wydawato mi się, że stusznie robię $i$ to jedyne możliwe rozwiazanie. Teraz już wiem, że to nieprawda, trochę mi dojście do tych wniosków zajęto. Po wyjściu na wolność planuje przede wszystkim znaleźć sobie prace dobrze płatna, bo chcę, żeby moja konkubina już się nie męczyła. Wystarczy, że tyle czasu sama harowata na rodzinę. [J.S. - 42 lata, rozwiedziony, mieszkaniec małego miasta, wykształcenie zawodowe, recydywista wielokrotny, wyroki skazujące za kradzieże i rozboje]

Z analizy wypowiedzi osób badanych wyłania się obraz dwu, biegunowo różnych sylwetek żon/konkubin pozostawionych na wolności. Jedne są postrzegane przez swoich mężów/konkubentów jako silne, zaradne i świetnie radzące sobie z wychowywaniem dzieci. Inne zaś - słabe, chore, oczekujące na wsparcie społeczne, niewydolne wychowawczo.

Siedze już drugi raz — mam 8,5 roku, z czego siedzę 3 prawie. Rodziny własnej jeszcze nie mam, znaczy tak, jestem w zwiazku od 8 lat, można to już więc zaczać nazywać rodzina. Moja dziewczyna jest starsza ode mnie o 14 lat, tak jak mówię, jestem z nia już 8 lat. Ma dwójkę dzieci, $z$ którymi mam bardzo dobry kontakt. To jest tak, jakbym zastępowat im trochę ojca. Bo ojciec można powiedzié́, że zostawit ich. Ja ich lubie $i$ oni też mnie lubiq. Jest dziewczynka (11 lat) i chtopak (13 lat). Moja dziewczyna niedawno miała raka, ale przeszła operację $i$ jest wszystko ok. Pobyt w więzieniu pogorszyt nasze relacje, ale to ze względu na to, że tyle kilometrów nas dzieli, może niedużo, ale dziewczyna pracuje dtugo, bo ona jest tlumaczem i po nocach siedzi tlumaczy różne rzeczy, książi itd. Ma czas zajęty, a poza tym ma dwójke dzieci, więc też ma się kim zajmować. Ale często dzwonie do niej i jak ona może, to do mnie tutaj przyjeżḋa. [D.P. - 33 lata, kawaler/konkubent, mieszkaniec dużego miasta, wykształcenie średnie, dwukrotny recydywista, wyroki skazujące za rozbój i kradzieże]

Badania wykazały, iż członkowie rodzin najmłodszych i najstarszych recydywistów, rzadziej niż członkowie rodzin osób z pozostałych kategorii wiekowych, nie pobierają świadczeń dodatkowych, takich jak emerytura czy renta. $\mathrm{Z}$ wypowiedzi osób badanych wynika, że taki stan rzeczy wiąże się $\mathrm{z}$ trudną sytuacją żon/konkubentek, które będąc młodymi matkami, samotnie wychowującymi dzieci, są zmuszone do podjęcia pracy, by móc utrzymać rodzinę choćby 
na najbardziej podstawowym poziomie. Te starsze natomiast są nadal $\mathrm{w}$ wieku produkcyjnym, sprzyjającym pozyskaniu zatrudnienia. W większości przypadków kobiety związane z badanymi recydywistami posiadają kwalifikacje zawodowe, zaś te, które posiadają niski poziom wykształcenia lub przygotowania zawodowego, radzą sobie poprzez wykonywanie dorywczych prac fizycznych, niewymagających posiadania kwalifikacji.

Niezależnie jednak od sytuacji materialnej członków rodziny lub statusu zawodowego jej członków, recydywiści penitencjarni planują w większości przypadków podjęcie zatrudnienia po zakończeniu kary izolacji i wyjściu na wolność. O poszukiwaniu pracy częściej myślą młodzi recydywiści, którzy są bardziej mobilni, gotowi do podejmowania wyzwań związanych z miejscem pracy. $Z$ drugiej strony są dla potencjalnych pracodawców atrakcyjni pod względem ponoszonych kosztów z uwagi na niewielki staż pracy. Jak wynika z przeprowadzonych wywiadów, pracodawcy chętnie zatrudniają młodych skazanych do prac fizycznych i niewymagających wysokich kompetencji czy dodatkowych kwalifikacji.

Motywacje recydywistów do podjęcia pracy są różne, ale ogólnie rzecz biorąc, niemal wszystkie wypowiedzi odnoszą się do sytuacji rodzinnej i chęci niesienia wsparcia finansowego pozostałym członkom rodziny — żonie, konkubinie, starszym rodzicom, własnym i przysposobionym dzieciom.

Muszę zmienić środowisko i uspokoić się, znaleźć prace, bo kasa z kradzieży już się skończyła, no i chcę wspomóc rodzinę. Rodzice sa już starzy, schorowani i nie radza sobie. Maja trudności z utrzymaniem się. Teraz będzie czas na mnie - to ja muszę być ich żywicielem, ale z legalnej pracy. [R.C. - 21 lat, kawaler, mieszkaniec wsi, wykształcenie podstawowe, recydywista wielokrotny, wyroki skazujące za kradzieże]

Badani recydywiści w wielu przypadkach myślą także o emigracji zarobkowej. Chcą zacząć w ten sposób życie niejako od nowa, z dala od dotychczasowych spraw, problemów i toksycznych relacji. Widzą w tym nadzieję na poprawę nie tylko sytuacji materialnej własnej rodziny, ale również na samoistny zanik etykiety przestępczej i budowanie siebie oraz swojego życia $z$ dala od miejsc, ludzi i społecznej wiedzy o ich kryminalnej przeszłości.

Starczy już tego, jest już dla kogo żyć, jest dziecko, nie chciałbym, żeby mój syn kiedyś popetnit ten sam bład. Wiadomo, dorośnie będzie miat swój rozum, ale będę na pewno próbowat mu tlumaczyć. Zrobi, jak zrobi, ale będę się starać, aby nie popetnit tych błędów, które ja popetnitem. Ale wiadomo, jakby doszło do najgorszego, że noga by mu się podwinęta, czy coś, to na pewno by miat wsparcie ode mnie. Nie pozwole mu sie zmarnować i mam nadzieję, że nie dojdzie do tego. Przede wszystkim będe próbowat, żeby ich wywieźć stą, nie chcę tu siedzieć w Polsce, nie ma tu sprawiedliwości, nie ma prawa, człowiek skazany po wyjściu, jest już 
skreślony, bo za byle co moga przyjść do domu, zapukać. „Pani powie, że to on, on już i tak siedziat, Pani swoje odszkodowanie dostanie, a my teczkę zamkniemy”. Nie chcę, nie chcę. Po wyjściu czas zacząć już się ogarnąć $i$ wyjechać stad, tam budować wszystko. Tu przyjeżdzać czasem, na jakieś święta czy coś. Myśle, że tu w Polsce, byłaby jakaś przyszłość ciężkimi krokami, ale nie, myśle, że nie starczy tego wszystkiego. [D.P. - 33 lata, kawaler/konkubent, mieszkaniec dużego miasta, wykształcenie średnie, dwukrotny recydywista, wyroki skazujące za rozbój i kradzieże]

W przerwach między wyrokami nie szukatem pracy, bo miatem sporo kasy z kradzieży. Ale teraz, jak wyjdę, będę szukat legalnej pracy za granica. Mój kumpel tam jest i mówi, że spoko. No, że można niezła kasę zarobić i nikt nie wie, kim jesteś i nie pyta, czy masz kryminalna przeszłość. A gdzie? — No na przyktad Anglia. [M.U. — 34 lata, kawaler, mieszkaniec miasta średniej wielkości, wykształcenie wyższe zawodowe, recydywista jednokrotny, wyroki skazujące za kradzieże, bójki i zabójstwo]

Plany badanych recydywistów związane z życiem na wolności są niekiedy podbudowane chęcią zmiany swojego statusu społecznego. Rozwojem osobistym, w tym rozwijaniem swoich pasji, najmniej zainteresowani są recydywiści posiadający rodziny i żyjący w sformalizowanych związkach. Większość badanych niechętnie odnosiła się do możliwości uzupełnienia wykształcenia, czy podniesienia jego poziomu po wyjściu na wolność, chociaż niektórzy recydywiści w średnim wieku nie wykluczali podjęcia dalszej edukacji. W podwyższaniu kwalifikacji upatrywali nie tylko własnych możliwości rozwojowych, ale także zdobycia lepszego wynagrodzenia za pracę.

Jeśli bylaby tylko taka możliwość i miatbym czas, to chciałbym dalej sie uczyć, zdobyć wyższe wykształcenie, aczkolwiek mam rodzinę, która mnie potrzebuje. Ktoś musi pracować, żeby zarobić na dom, nie wiem, czy datoby się to pogodzić z obowiąkami domowymi $i$ zadbaniem o rodzinę. Najważniejsza jednak dla mnie w tym momencie jest dobra i godna praca i zapewnienie rodzinie wszystkiego, czego potrzebuje. [M.K. — 40 lat, żonaty, mieszkaniec dużego miasta, wykształcenie zawodowe, recydywista wielokrotny, wyroki skazujące za pobicia i rozboje]

Reasumując, badani recydywiści snują realistyczne plany życia na wolności po zakończeniu kary izolacji. W ich wypowiedziach przebija się troska o siebie i rodzinę, o byt codzienny i lęk przed odrzuceniem społecznym. Symptomatyczne jest podkreślanie wagi posiadania mieszkania i pracy do ustabilizowania sytuacji wolnościowej. Ich brak skutkuje porażką readaptacyjną i powrotnością do przestępstwa. Odnosząc się do swoich doświadczeń z przeszłości, wielu recydywistów wskazywało na osamotnienie, bezradność i fiasko swoich dążeń do spełnienia tych podstawowych warunków. Pozostając w dramatycznej sytuacji, czuli się przymuszeni do sięgania po dawne przestępcze metody radzenia sobie. 
Karani w warunkach recydywy pozostawiali na wolności swoje rodziny, które utknęły w szczególnie trudnej sytuacji życiowej.

Nie ulega wątpliwości, że problem przestępczości może dotknąć każdego typu rodzinę, ale najczęściej dotyczy tych rodzin, w których spirala kryzysu nakręca się wokół jego pierwotnego źródła: bezrobocia, biedy, uzależnień, a których to pochodną jest przestępczość. Cechuje je niski poziom przystosowania zarówno do zmian będących skutkiem dynamicznego przekształcania się otoczenia, jak i niski poziom przystosowania do zmian, wynikających z naturalnego rozwoju rodziny i z sytuacji pojawiających się nagle i niespodziewanie. Tkwiąc w stanie polidysfunkcji, są postrzegane społecznie jako mniej wartościowe, słabe strukturalnie i niewydolne funkcjonalnie. Rodziny z problemem przestępczości i ich członkowie są stereotypowo przynależni do kategorii „Inny”. Piętno inności obciąża wszystkich członków rodziny i modyfikuje antycypacje społeczne. $\mathrm{Z}$ uwagi na negatywną percepcję otoczenia społecznego, rodziny z problemem przestępczości są lokowane w dyskredytowalnej kategorii rodzin upośledzonych społecznie. Nie są one jednak w stanie samodzielnie wydobyć się ze splotu nierozwiązanych i nawarstwiających się problemów, czego implikacją jest konieczność uruchomienia zewnętrznych sił pomocowo-wspierających.

Wyniki badań własnych spójne z wynikami badań innych autorów wskazują na wzrost prawdopodobieństwa powrotu do przestępstwa w sytuacji, gdy po wyjściu na wolność byli więźniowie nie mają zapewnionych stabilnych warunków mieszkaniowych (zerwanie kontaktów z rodziną, brak własnego mieszkania, bezdomność) oraz w miarę stabilnego zatrudnienia [m.in. Dzierżyńska-Breś 2020, 2016; Szczepanik, Miszewski 2016]. Gdy nie posiadają co najmniej średniego wykształcenia [Beard, Johnson \& Kemp 2003] oraz silnego wsparcia rodzinnego [m.in. Dzierżyńska-Breś 2020; Nowak 2019b, 2017a, 2016; Szczepanik, K. Miszewski 2016].

Generalnie rzecz ujmując, aby nastąpić mogła pozytywna reintegracja społeczna ekswięźniów, społeczeństwo w trosce o utrzymanie ładu społecznego i zapewnienie poczucia bezpieczeństwa powszechnego, zobowiązane jest do opieki postpenitencjarnej i wsparcia społecznego byłych więźniów oraz holistycznej opieki nad ich rodzinami. 
Żaden czlowiek nie jest samoistna wyspa; każdy stanowi ułomek kontynentu, część ladu.

John Donne*

* Pierwsze dwa wersy motta z książki: E. Hemingway (2002). Komu bije dzwon. Warszawa: Libros (Bertelsmann Media). 


\section{Część IV \\ Reintegracja społeczna — od patologii do normy zachowań społecznych}





\subsection{Iluzja reintegracyjna: kalejdoskop (nie)skuteczności systemowych}

Polskie systemy profilaktyki i resocjalizacji oraz pomocy postpenitencjarnej są od lat dysfunkcjonalne ${ }^{4}$. Przemawiają za tym głównie trzy podstawowe fakty, które dotyczą po pierwsze pomiaru efektów resocjalizacji za pomocą wskaźnika negatywnego, czyli szacowania wskaźnika recydywy, po drugie, braku systemu monitorowania skazanych opuszczających jednostki penitencjarne oraz po trzecie - niedostatecznego zaopatrywania osadzonych w informacje podstawowe i niezbędne w konstruktywnym radzeniu sobie na wolności, zwłaszcza w pierwszym okresie po uwolnieniu. Inne, równie ważne czynniki ryzyka powrotności ekswięźniów do przestępstwa, to brak wspomagania ich rodzin pozostawionych na wolności, brak ramowego, kompleksowego i profesjonalnie przygotowanego programu ukierunkowanego na proces destygmatyzacji ekswięźniów i ich rodzin, jednostronne działanie w ramach pomocy społecznej (rozdawnictwo środków pieniężnych) oraz nikłe wykorzystywanie kontraktu socjalnego, uznanego za najbardziej efektywne narzędzie do wspomagania reintegracyjnego [Rymsza 2012]. Do tego dochodzą jeszcze przeciążenia kuratorów sądowych czynnościami biurokratycznymi oraz liczbą dozorów i nadzorów, wskutek czego ich praca staje się mało efektywna. Próby zniwelowania niesprawności systemowych podejmowane są przez społeczności lokalne, organizacje pozarządowe (stowarzyszenia i fundacje) oraz centra wolontariatu, które skutecznie wspierają ekswięźniów w pierwszym, najtrudniejszym okresie readaptacji społecznej. Są to jednak działania wybiórcze, krótkotrwałe i skoncentrowane na osobie ekswięźnia oraz niezwykle rzadko obejmujące równoległym wspomaganiem również jego rodzinę. W przestrzeni społecznej realizowane są także liczne projekty unijne dedykowane ekswięźniom i ich rodzinom, ale mają one charakter incydentalny i ograniczony czas realizacji.

Opisane niesprawności systemowe utrzymują się od lat na tym samym poziomie, mimo wielu prób zmiany tej sytuacji, w tym przez środowisko naukowe, którego reprezentanci dostarczają znaczących wyników badań empirycznych i modeli pracy z osobami zagrożonymi ekskluzją społeczną [Bałandynowicz,

4 Najwyższa Izba Kontroli, Readaptacja społeczna skazanych na wieloletnie kary pozbawienia wolności. Wyd. Departament Porządku i Bezpieczeństwa Publicznego. Warszawa, listopad 2015. 
Konopczyński, Ambrozik, Nowak, Fidelus, Mudrecka, Kieszkowska czy Szafrańska].

Proces reintegracji byłych skazanych ze społeczeństwem jest wielozakresowy i wymagający podbudowy systemowej. Chodzi przede wszystkim o to, by rozwiązania systemowe stanowiły ogniwo wspierające działania podmiotów usytuowanych w sieci lokalnych instytucji i organizacji samorządowych. Dotychczasowe działania systemowe nie zapewniają warunków do sprawnego i efektywnego działania społeczności lokalnych na rzecz ekswięźniów powracających do środowiska życia po zakończeniu kary izolacji. Nie dają również możliwości wspomagania ich polidysfunkcyjnych rodzin, które nie radząc sobie samodzielnie z różnorakimi problemami, ulegają powolnej autodestrukcji. Osamotnieni i okaleczeni życiowo członkowie rodzin z problemem penitencjarnym powielają patologie rodzinne, zasilając obszar niedostosowania społecznego, marginalizacji i wykluczenia społecznego. Tylko nielicznym ekswięźniom i ich rodzinom udaje się wyjść z zaklętego koła powrotności do przestępstwa. Pozostali mogą liczyć jedynie na szczęśliwy zbieg okoliczności lub szybką zmianę dotychczasowego działania systemowego. Sprawą niezwykle pilną jest przede wszystkim opracowanie spójnego, holistycznego programu reorientacji przestępczego stylu życia ekswięźniów, w kierunku rzeczywistej poprawy moralnej i przyjęcia stylu życia wolnego od kryminalnego piętna.

Odnosząc się do obecnej sytuacji, należy podkreślić, że proces reintegracji społecznej ekswięźniów ma charakter fazowy. Efektywność pierwszej fazy, czyli resocjalizacji, wydaje się w polskiej rzeczywistości co najmniej wątpliwa, zaś dwie kolejne - readaptacja i finalnie reintegracja społeczna — są zwykle nieudane i kończą się powrotnością ekswięźniów do przestępstwa.

Z raportu Ministerstwa Sprawiedliwości za lata 2012-2016 ${ }^{5}$ wynika, że do 2015 roku regularnie malała liczba prawomocnie skazanych recydywistów (z $19497 \mathrm{w} 2012$ roku do $14458 \mathrm{w}$ roku 2015), w tym identyfikowanych na podstawie art. $64 \S 1$ (z 17581 do 12 845) oraz skazanych z $\S 2$ k.k. (z 1916 do 1613). W następnym roku zaobserwowano jednak nagły wzrost niemal wszystkich wskaźników. Liczba prawomocnie skazanych recydywistów wzrosła o 1895 osób, w tym o 1486 osób identyfikowanych na podstawie art. $64 \S 1$ oraz o 409 osób skazanych z § 2 k.k.

W ogólnej liczbie skazanych w latach 2012-2016 sukcesywnie wzrastał także odsetek recydywistów (z 4,7\% w roku 2012 do ponad 5,6\% w roku 2016). W roku 2016 najczęściej skazywani byli recydywiści w kategorii wiekowej 25-34 lat, zaś najrzadziej młodociani (17-21 lat). W analizowanym okresie najwięcej recydywistów skazano w województwach: mazowieckim, śląskim i dolnośląskim, natomiast najmniej w opolskim. Odsetek osób prawomocnie skazanych w roku 2012, które powróciły do przestępstwa w latach 2012-2016, systematycznie malał od 53,48\% w 2012 roku do $0,94 \%$ w 2016 roku.

5 https://prawo.uni.wroc.pl/sites/default/files/students-resources/statystyka-sadowa.-prawomocne-skazania-osob-doroslych-2012-2016-16.03.2018.pdf [dostęp: 15.11.2020]. 
W roku 2017 znów nastąpił spadek liczby prawomocnie skazanych recydywistów o 2028 osób, w porównaniu z rokiem 2016. Tę tendencję zaobserwowano również w odniesieniu do obu rodzajów recydywy, ale znów nastąpił wzrost odsetka recydywistów w ogólnej liczbie skazanych z 5,6\% w roku 2016 do 5,9\% w 20176. W kolejnym roku (stan na dzień 31.12.2018), w jednostkach penitencjarnych karę odbywało ogółem 36833 recydywistów penitencjarnych, w tym 22653 osób w warunkach art. 64 k.k. [17 762 skazanych z art. 64 § 1 k.k. (recydywa szczególna) oraz 4891 skazanych z art. 64 § 2 k.k. (recydywa specjalna wielokrotna) $]^{7}$.

Porównując powyższe dane z obecnie dostępnymi (stan na dzień 31.12.2019), zauważyć można nieznaczny wzrost ogólnej liczby osadzonych recydywistów penitencjarnych (37 307 osób). Zauważalny jest jednak wprawdzie niewielki, ale spadek liczby recydywistów odbywających karę w warunkach art. 64 k.k. (22 482 osób). Liczba skazanych z art. $64 \S 1$ k.k. utrzymuje się niemal na tym samym poziomie (17 774), natomiast nieznacznie spadła liczba recydywistów skazanych z art. $64 \S 2$ k.k. $(4708)^{8}$.

Przytoczone wyżej statystyki wskazują na wieloletnie utrzymywanie się wskaźników recydywy. W dużej mierze odpowiedzialne za ten stan rzeczy są rozproszone, niewystarczające i nieskutecznie prowadzone działania systemowe. Pomoc postpenitencjarna jest dedykowana wyłącznie byłym więźniom. Działania pomocowo-wspierające ich rodziny nie są podejmowane w sensie działań bezpośrednich i celowych. Rodzinom więźniów i byłych więźniów udzielane jest wsparcie pośrednie poprzez oddziaływania resocjalizacyjne podejmowane przez Służbę Więzienną wobec ich uwięzionych członków. Dotyczy to głównie aktywizacji zawodowej skazanych posiadających niski poziom wykształcenia i związane z tym głębokie deficyty wiedzy i umiejętności. Wielu z nich nie posiada nawyku pracy, gdyż przed osadzeniem zatracili oni potrzebę aktywności społeczno-zawodowej.

Zakres udzielanej ekswięźniom pomocy postpenitencjarnej jest wybiórczy i skoncentrowany na aspekcie finansowo-materialnym. Podkreślenia wymaga fakt zmniejszania się w ciągu trzech ostatnich lat liczby świadczeń we wszystkich zakresach założonej pomocy. Niepokojący jest szczególnie znaczny spadek liczby świadczeń związanych z udziałem byłych więźniów w programach podnoszących kompetencje społeczne, przeciwdziałających agresji, przemocy, uzależnieniom (od $23558 \mathrm{w}$ roku 2017 do $18798 \mathrm{w}$ roku 2019) $)^{9}$. Zaniedbywana jest także sfera psychospołecznego funkcjonowania ekswięźniów, $w$ tym proces

\footnotetext{
${ }^{6}$ file:///C:/Users/Dell/Downloads/statystyka-sadowa.-prawomocne-osadzenia-osob-doroslych-2013-2017.pdf [dostęp: 15.11.2020].

7 https://sw.gov.pl/strona/statystyka-roczna — file://C:/Users/Dell/AppData/Local/Temp/ rok\%202018-1.pdf [dostęp: 15.11.2020].

8 https://sw.gov.pl/strona/statystyka-roczna — file://C:/Users/Dell/Downloads/rok\%202019. pdf) [dostęp: 15.11.2020].

9 https://www.sw.gov.pl/strona/statystyka-roczna - roczna informacja statystyczna za lata 2017, 2028 i 2019 [dostęp: 16.11.2020].
} 
destygmatyzacji, rehabilitacja zdrowotna $\mathrm{z}$ uwagi na różnorakie, negatywne skutki izolacji więziennej, poradnictwo i pośrednictwo pracy oraz sprawiedliwość naprawcza. W większości przypadków pomijany jest także aspekt rozwojowy, związany z konstruktywną i zgodną z normami społecznymi samorealizacją ekswięźniów. Znaczące zaniedbania dostrzegane są także w przygotowaniu kompetencyjnym skazanych, w aspekcie radzenia sobie z problemami i trudnościami dnia codziennego, naprawy i wzmocnienia gasnących więzi rodzinnych oraz ich trwałego utrzymania, nabycia umiejętności wychowawczych oraz reorientacji niekorzystnych postaw rodzicielskich.

Po zakończeniu etapu przygotowawczego do wyjścia na wolność, który zazwyczaj jest prowadzony pobieżnie i nieefektywnie, skazani opuszczają mury więzienia. Przekraczają granicę pomiędzy izolacją a ponownym uczestnictwem społecznym w dawnym, zazwyczaj patogennym środowisku życia. Brak czynników chroniących — rodziny, mieszkania, pracy i pomocy społecznej, przyczynia się w sposób znaczący do popełniania przez nich przestępstw i ponownego skazania w warunkach recydywy. W społecznościach lokalnych jest wielu ekswięźniów — nieumiejących samodzielnie egzystować, zagubionych i błąkających się w poszukiwaniu instytucjonalnego wsparcia lub też hardych, pewnych siebie i znów działających przestępczo. Zarówno jedni, jak i drudzy, pozbawieni skutecznego wsparcia instytucjonalnego, w sytuacji braku możliwości rozwiązania nabrzmiałych problemów egzystencjalnych, wracają po pewnym czasie do więzień, albo też zasilają obszar radykalnego wykluczenia społecznego i wegetują w społecznościach osób bezdomnych. Taka jest niestety smutna powięzienna rzeczywistość.

Na taki obraz składa się wiele czynników, począwszy od oddziaływań resocjalizujących, prowadzonych $\mathrm{w}$ izolacji penitencjarnej zazwyczaj $\mathrm{z}$ miernym skutkiem przez zaniechania systemowe $\mathrm{w}$ zakresie wspomagania pozostawionych na wolności rodzin osób osadzonych po niedostateczne przygotowywanie skazanych do życia na wolności w okresie sześciu miesięcy przed zakończeniem kary oraz brak systemu monitorowania i holistycznego wspomagania reintegracyjnego ekswięźniów i ich rodzin.

W tym miejscu chciałabym zatrzymać się przy zagadnieniu przygotowania skazanych do wyjścia na wolność. Otóż niesprawność, a nawet iluzoryczność tego procesu wynika w mojej ocenie $\mathrm{z}$ nałożenia na funkcjonariuszy więziennych zbyt obciążających i wielorakich czynności zawodowych. Przygotowanie osób osadzonych do odnalezienia się w znacznie zmienionych warunkach społeczno-ekonomiczno-gospodarczych, do sprawnej orientacji w lokalnej sieci wspomagania społecznego oraz do samodzielnego podejmowania aktywności prowadzącej do pozbycia się piętna kryminalisty wymaga wielu zabiegów ujętych w ramy działania celowego i zaprogramowanego na uzyskanie optymalnego efektu. Niezbędne jest między innymi opracowanie i wdrożenie planu kompleksowego i warsztatowo prowadzonego szkolenia więźniów W zakresie radzenia sobie na wolności z ich realnymi problemami oraz realizacji cyklu treningów kompetencyjnych. Te wszystkie czynności wymagają od ich realizatorów profesjonalnego przygotowania i wyłącznego skupienia się na 
wykonywanych zadaniach. Ponadto, ustawowo zapisane pół roku jest okresem ewidentnie zbyt krótkim na wprowadzenie skazanych w arkana życia społecznego oraz wypracowania $u$ nich kompetencji niezbędnych do samodzielnego organizowania życia, szukania pomocy i wsparcia w gąszczu różnorakich układów społecznych, w tym ujętych w ramy instytucjonalne.

Nam, „normalsom”, umyka gdzieś perspektywa globalna i rozmywa się ostateczny wizerunek resocjalizowanego podmiotu, a nade wszystko wizja osadzenia go na nowo w przestrzeni społecznej tak, by stał się zdrowym elementem tkanki społecznej. Trzeba zatem w taki sposób przeanalizować i ocenić aktualną sytuację oraz skonstruować takie modele reintegracji społecznej, by móc odszukać w splotach różnorakich uwarunkowań, możliwości i zaangażowania społecznego, podmiot starający się o odnalezienie swojego miejsca w rzeczywistości, do której powrócił zresocjalizowany, gotowy do działania i przyjmowania wspomagania społecznego albo niezresocjalizowany, wikłający się w różnorakie sytuacje przestępczorodne. Obie te postaci zlewają się w jedną — byłego więźnia — wymagającego wielostronnych oddziaływań wspomagających: treningu kompetencyjnego, wsparcia finansowego, psychologicznego, terapeutycznego, prawnego czy medycznego.

W wersji optymistycznej, pozytywna i adekwatna do potrzeb odpowiedź społeczna, znacznie zwiększy prawdopodobieństwo względnie trwałej reintegracji społecznej ekswięźniów. Trzeba jednak spojrzeć na ten problem z daleko idącą rezerwą, gdyż będzie i tak, że bez względu na starania społeczeństwa, status społeczny czy sytuację życiową, część ekswięźniów będzie co jakiś czas przywdziewała znany sobie kostium tożsamościowy i będzie odgrywała głęboko zinternalizowaną rolę kryminalisty. Odpowiedzialne za to są bowiem niekorygowalne cechy osobowościowe, nieusunięte niedoskonałości charakterologiczne i zapóźnienia socjo-kulturowe oraz trwałe zaburzenia poznawcze.

Wracając do sedna poruszanych zagadnień, należy pamiętać, że zasadniczym i nadrzędnym celem kary pozbawienia wolności, a tym samym podstawową funkcją zakładu karnego jest izolacja osoby skazanej, a dopiero w drugiej kolejności dążenie do jej trwałej poprawy moralnej. Realizacja tego ostatniego zamierzenia wymaga stymulowania jej do dokonania radykalnych przeobrażeń tożsamości oraz modyfikacji cech charakteru. Przede wszystkim jednak najważniejsze zmiany dotyczyć muszą sposobu myślenia osoby skazanej o sobie i innych, o otaczającej rzeczywistości bio-socjo-kulturowej, opanowania umiejętności konstruktywnego i skutecznego działania oraz zachowania zgodnego z oczekiwaniami społecznymi.

Praca resocjalizacyjna ze skazanymi, zarówno na etapie izolacji więziennej, jak i w warunkach wolnościowych, powinna być ukierunkowana na osiąganie stanu ich psychologicznego zakorzenienia i przyjęcie nowej koncepcji życia. Zasadniczą funkcję $\mathrm{w}$ tym procesie pełnić mogą dostarczane skazanym impulsy skłaniające ich do poszukiwania wiedzy o życiu, zmiany hierarchii wartości, stawiania celów życiowych i wytyczania ścieżek ich realizacji, zmiany stosunku do siebie i innych osób, autokontroli moralnej w podejmowanych działaniach oraz autokreacji heurystyk globalnego osądu życia i określania perspektywy 
czasowej. Wszystko to ma za zadanie wzbudzać w skazanych przekonanie, że istnieją idee i wartości, które nadają sens ludzkiemu życiu. Istota tego procesu tkwi w doświadczaniu głębokich transformacji osobowościowych. W modelu skutecznej pracy resocjalizacyjnej wyodrębnić można podstawowe reorientacje:

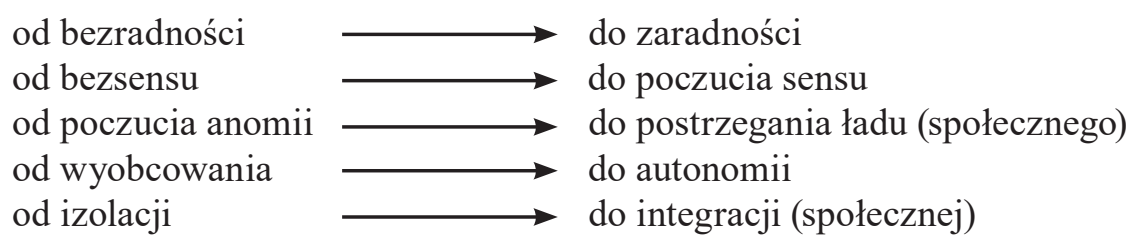

W warunkach izolacyjnych projektowanie według powyższego modelu aktywności podmiotu resocjalizowanego, ukierunkowanej na dokonywanie zmian wewnętrznych jest jednak trudne i mało skuteczne. Odpowiedzialne są za to między innymi negatywne skutki długotrwałej izolacji więziennej, które zaburzają proces dochodzenia do pożądanych stanów i przeobrażeń osobowościowych. Wymaga to od instytucji izolacyjnej wykreowania określonego kontekstu społecznego, a od jej funkcjonariuszy — intencjonalności oraz zdolności do świadomego stosowania reguł oraz realizowania założonych planów i strategii ukierunkowanych na osiąganie pożądanych stanów rzeczy. Są to warunki trudne do spełnienia przede wszystkim z uwagi na konieczność bezwzględnego stosowania procedur bezpieczeństwa i wykonywania powtarzalnych czynności służących normowaniu życia więziennego. Dlatego też, mimo usiłowań kadry penitencjarnej oraz realizacji różnorodnych programów i zabiegów resocjalizacyjnych, w powszechnym przekonaniu resocjalizacja prowadzona w więzieniu jest nieefektywna. Instytucja totalna, a taką jest więzienie, posiada bowiem z góry określony kontekst społeczny uniemożliwiający realizację procesu uspołecznienia, który z założenia powinien być realizowany w warunkach wolnościowych.

Załóżmy teraz, że doszliśmy do miejsca, w którym zresocjalizowani skazani wychodzą na wolność. Czas zatem przeanalizować możliwy przebieg procesów prowadzących ich do pozytywnej reintegracji społecznej. Otóż w pierwszej fazie, którą jest resocjalizacja realizowana $\mathrm{w}$ warunkach izolacji więziennej, chodzi o podwyższenie poziomu gotowości skazanych do zaspakajania potrzeb (w ramach odgrywania ról życiowych, zawodowych i społecznych) w sposób prawidłowy i zgodny z oczekiwaniami społecznymi. Na pół roku przed zakończeniem kary izolacji rozpoczyna się kolejna faza, czyli readaptacja społeczna, a w zasadzie przygotowanie do podjęcia próby bezkolizyjnego wpasowania się w życie społeczne na wolności. I wraz z zamknięciem bram więzienia, były już więzień zostaje skazany na negocjowanie znaczeń społeczno-środowiskowych oraz ponowne zaadaptowanie się w sposób konstruktywny i bezpieczny dla siebie i innych. Jest to dla niego trudne, obciążające, ale w większości przypadków możliwe do wykonania. Warunkiem powodzenia jest posiadanie umiejętności samodzielnego testowania własnych oraz środowiskowych 
możliwości readaptacyjnych, ze znacznym wspomaganiem sił społecznych osobowych, wspólnotowych i instytucjonalnych.

Dobrze opracowane holistyczne ścieżki reintegracyjne mogą prowadzić byłych więźniów i ich polidysfunkcyjne rodziny do destygmatyzacji i uzyskania statusu rodzin funkcjonalnych. Należy podkreślić, że destygmatyzacja jest podstawą sukcesu reintegracyjnego. Aby cel ten został osiągnięty, musi zostać spełniony warunek konieczny, czyli osiągnięcie przez ekswięźnia sukcesu readaptacyjnego, warunkowanego skutecznością jego (re)edukacji i resocjalizacji, efektywnością działania sieci lokalnego wsparcia społecznego oraz siłą więzi rodzinnych i jakością relacji nawiązywanych przez czlonków rodziny.

Narracje recydywistów penitencjarnych oraz próba adaptacji rozwiązań systemowych skutecznych w innych sferach działania społecznego stanowią fundament autorskiej propozycji zmiany zastanego stanu rzeczy, służącej modyfikacji dotychczasowego systemu pomocy penitencjarnej i postpenitencjarnej, niezmiernie rzadko skutkującego indywidualnym, a także trwałym sukcesem reintegracyjnym.

\subsection{Wspomaganie reintegracyjne ekswięźniów w ujęciu sieciowo-systemowym}

W środowisku naukowym wciąż trwają dysputy nad kształtem penitencjarnych i postpenitencjarnych rozwiązań systemowych. W sensie teoretycznym wiele spraw zostało już rozstrzygniętych. Wiemy przecież, że należy sprawiedliwie karać i resocjalizować, gdy tylko jest to możliwe; resocjalizować w środowisku otwartym, ale nie zaniedbywać środowisk penitencjarnych; poszukiwać jasnych stron i wykorzystywać potencjały drzemiące w resocjalizowanych podmiotach; nie pozwalać na zmarnowanie potencjału ludzkiego uwięzionych — dawać im szansę na wyjście z osamotnienia, załamania i kryzysu [Pytka, Nowak 2010, s. 10]. Jednak bez aktywnego udziału społeczeństwa dokonanie tych zamierzeń jest niemożliwe. Decydujące jest tu wypracowanie zbiorowej otwartości i gotowości do wspomagania tych, którzy zostali skazani, odbyli karę i znów powrócili do społeczeństwa. Bez tego oraz jasno sprecyzowanych celów operacyjnych, rzetelnej wiedzy teoretycznej, empirycznej i praktycznej oraz wysokich kompetencji osób wspomagających, reintegracja społeczna ekswięźniów narażona jest na porażkę. Nieskuteczne zakończenie faz poprzedzających ten proces - resocjalizacji i readaptacji społecznej — prowadzi bowiem ekswięźniów do powrotności do przestępstwa i kolejnego pobytu w więzieniu. W ten sposób, mimo dobrych intencji, powstaje swoiste koło niewydolności systemowej. Nie ulega też wątpliwości, że recydywa sprzyja utrwalaniu myślenia przestępczego i kontynuowaniu przestępczego stylu życia. W jaki zatem sposób można skutecznie przeciwdziałać tym negatywnym tendencjom? 
Otóż przede wszystkim wspomaganie reintegracyjne skazanych, które rozpoczyna się w miejscu osadzenia i prowadzone jest zarówno w warunkach izolacji więziennej, jak i w warunkach wolnościowych, powinno być ukierunkowane na realizację strategii prowadzących do osiągania stanu ich psychologicznego zakorzenienia [Niewiadomska 2011]. Proces ten jest oparty na wzbudzaniu przekonania, że istnieją idee i wartości, które nadają sens ludzkiemu życiu. Polega on na kompleksowym doświadczaniu transformacji osobowościowych: od bezradności do zaradności (konstruktywnego sprawstwa); od bezsensu do odczuwania sensowności; od poczucia anomii do postrzegania ładu społecznego; od izolacji do integracji; od wyobcowania do autonomii. Poprzez (re)edukację oraz przyjęcie nowej koncepcji życia wraz z podsystemami [Kaja 2010]: wiedza o życiu, wartości, cele życiowe i ścieżki ich realizacji, stosunek do siebie i innych osób, kontrola moralna działań, heurystyki globalnego osądu życia i perspektywa czasowa - skazani mogą doświadczyć psychologicznego przejścia na ,jasną stronę mocy”. Proces ten warunkowany jest zarówno zmianami osobowościowymi i tożsamościowymi, jak i wsparciem środowiskowym, w tym rodzinnym. Są to kluczowe czynniki chroniące skazanych przed wejściem na ścieżkę recydywy. Celem reintegracji społecznej staje się zatem osiągnięcie przez skazanych optymalnego poziomu zdolności do samodzielnego zaspakajania potrzeb i radzenia sobie $\mathrm{z}$ problemami w sposób prawidłowy, zgodny z oczekiwaniami społecznymi i wymogami kulturowymi.

Powracając do meritum zagadnienia, należy podkreślić, że przedmiotem wspomagania reintegracyjnego jest swoista diada: osoba skazana, która po zakończeniu kary pozbawienia wolności powraca do środowiska swojego życia oraz proces udzielania jej pomocy w konstruktywnej adaptacji do warunków wolnościowych przez społeczność lokalną. Takie ujęcie procesu reintegracji społecznej osadzone jest w psychologii humanistycznej. Wyznacza ono kierunek działań osób wspomagających na odkrywanie wartości, nadanie znaczenia oraz zrozumienie problemów życiowych i potrzeb jednostki (grupy) będącej ich adresatem.

Wspomaganie jest pojęciem, które należy rozumieć jako „,...] specjalny rodzaj interakcji międzyludzkich (człowieka z człowiekiem, człowieka z ludźmi czy też ludzi z ludźmi” [Kaja 2010, s. 28]. W omawianym przypadku interakcja stanowi podstawowy element procesu wywierania wpływu, rozumianego jako siła oddziaływania ukierunkowana na osiągnięcie zamierzonego, nadrzędnego celu, którym jest pozytywna readaptacja społeczna ekswięźniów i ich ponowne zintegrowanie ze społeczeństwem. Wspomaganie oznacza podejmowanie intencjonalnych oddziaływań, umożliwiających jednostce samodzielne rozwiązywanie problemów życiowych, wykonywanie zadań i branie odpowiedzialności za efekty własnego działania. Pomaganie jest natomiast nastawione na dobro innych osób i oznacza podjęcie aktywności zorientowanej na udzielenie im bezpośredniej pomocy w celu wsparcia podejmowanych przez nich działań. Oznacza to, że wspomaganie jest procesem długofalowym i stymulującym podmiot do zmiany, zaś pomaganie jest stosunkowo krótkotrwałym, często wybiórczym i incydentalnym podtrzymaniem podjętej przez podmiot 
aktywności. Istotne jest przy tym to, że pomaganie może stanowić bazowy element procesu wspomagania.

Kategorią kluczową w procesie osiągania pozytywnej i trwałej reintegracji społecznej ekswięźniów jest odpowiedzialność. Wynika to z faktu, iż zachowania wspomagające i pomocne mają charakter prospołeczny. Człowiek podejmuje tego typu działania, gdy uzmysłowi sobie potrzeby innego człowieka i oszacuje, że może pomóc mu je zaspokoić, a tym samym może wpłynąć pozytywnie na jego sytuację i jednocześnie przyjmie, że właśnie to on jest odpowiedzialny za udzielenie mu pomocy [Reykowski 1986]. Analizując pojęcie odpowiedzialności w perspektywie podmiotu wspomaganego, należy podkreślić wagę jego kształtowania w procesie resocjalizacji. Ponoszenie odpowiedzialności za własne działanie w przeszłości i teraźniejszości oraz za projektowanie własnej przyszłości, jest zarazem warunkiem i wskaźnikiem osiągania założonych celów resocjalizacyjnych. Rozwój poczucia odpowiedzialności daje realną możliwość reorientacji normy moralnej — od wyrządzania zła do czynienia dobra [Mudrecka 2010]. Odpowiedzialność jest także siłą aktywnie kształtującą relacje społeczne i zabezpieczającą życie ludzi. To powiązanie odpowiedzialności ze społeczną mocą Wilhelm Vossenkuhl [2012] nazywa troską. Dzięki swojej społecznej naturze ludzie nawiązują relacje wzajemnej troski - zawsze troszczą się o siebie, innych ludzi, o rzeczy lub plany życiowe.

Następnymi dwoma terminami operacyjnymi i kluczowymi w planowaniu i realizacji procesu wspomagania reintegracyjnego są skuteczność i efektywność. Oba te pojęcia mają wspólny rdzeń, czyli zdefiniowaną na gruncie prakseologii sprawność działania, której wskaźniki określają relacje pomiędzy celem, nakładem i efektem. W ujęciu Maxa Webera sprawność działania społecznego ${ }^{10}$ oznacza zdolność organizacji i instytucji do radzenia sobie w warunkach ciągłej zmienności, podejmowania interakcji z podmiotami zewnętrznymi oraz wykorzystywania potencjałów tkwiących w ludziach i ich otoczeniu [por. Maier 1982; Weber 2002, tł. Lachowskiej]. Atrybut sprawności będą posiadały zatem tylko te działania, które są ekonomiczne, skuteczne oraz korzystne [Walkowiak 2011, s. 29]. Weberowskie podejście do sprawności działania społecznego widoczne jest również w innych teoriach socjologicznych, między innymi w interakcjonizmie symbolicznym (ludzie działają na podstawie znaczeń rzeczy pochodzących $\mathrm{z}$ interakcji, które modyfikują $\mathrm{w}$ aktualnych i potencjalnych sytuacjach przez subiektywną interpretację), a także w teorii racjonalnego wyboru, wyprowadzonej z teorii gier i teorii decyzji (ludzie działają na bazie własnych, racjonalnych kalkulacji kosztów i korzyści). Warunkami koniecznymi do osiągania wysokiego poziomu sprawności działania społecznego jest ścisłe sprecyzowanie celu; ustalenie potrzeb i priorytetów, warunków, środków i sposobów działania, pozyskiwanie zasobów niezbędnych do jego realizacji oraz monitorowanie zgodności

10 Max Weber pojęcie działania społecznego odnosi do zachowania innych ludzi i ukierunkowania na nie. 
podejmowanych zadań z założeniami — realizacja planu i jego kontrola [Frąckiewicz 2001, s. 81].

Konstytutywną cechą sprawnego działania jest z kolei skuteczność. Z uwagi na obecność tego terminu w wielu dyscyplinach naukowych jest on rozmaicie definiowany — między innymi jako:

- umiejętność wyboru właściwych celów [Penc 1997];

- funkcja, zarówno właściwości systemu realizującego zadanie, jak i specyfiki samego zadania [Kotarbiński 1955];

- stopień realizacji zaplanowanych działań [ISO 9000, p. 3.2.14];

- cecha sprawnego działania [Zieleniewski 1982];

- zdolność człowieka do wykonywania określonych czynności [Cabała 2007].

We wszystkich ujęciach definicyjnych widoczny jest jednak wyraźny związek celu działania z jego wynikiem, co oznacza, że skuteczność jest środkiem do osiągania wysokiej efektywności podjętych działań [Helms 2006].

Efektywność odnosi się do zasady racjonalnego gospodarowania, formułowanej $\mathrm{w}$ dwóch wariantach: oszczędnościowym (minimalizacja nakładu) i wydajnościowym (maksymalizacja efektu). Działanie jest ekonomiczne wówczas, gdy wynik przewyższa koszt jego realizacji. W świetle teorii zasobów Stevana E. Hobfolla [2006, s. 72] pomiarowi podlegają te nakłady i efekty działania społecznego, które odnoszą się do zasobów zewnętrznych (m.in. środków finansowych i materialnych), wewnętrznych (m.in. zasobów osobistych i energii) oraz osiągnięć (np. technologicznych).

Projektowanie wspomagania reintegracyjnego wymaga nawiązania do dorobku różnych dyscyplin naukowych oraz wyników wieloaspektowych badań empirycznych. Na etapie wdrażania konkretnych rozwiązań niezbędne jest natomiast budowanie lokalnych koalicji instytucjonalnych, w celu utworzenia sieci wsparcia społecznego adresowanego do ekswięźniów i ich rodzin oraz innych jednostek i grup zmarginalizowanych, zagrożonych wykluczeniem i wykluczonych społecznie.

\subsubsection{Podejście sieciowo-systemowe w projektowaniu wspomagania readaptacyjnego}

Sieciowo-systemowy sposób myślenia o readaptacji społecznej daje szansę na opracowanie i realizację programów skutecznie wspomagających ekswięźniów i ich rodziny w wysiłkach zmierzających do osiągnięcia dobrostanu jednostkowego i wspólnotowego oraz pełnej inkluzji społecznej. Schemat działania sieciowo-systemowego oparty musi być na powiązaniach poziomych kreowanych w ramach lokalnej sieci działania międzyinstytucjonalnego oraz pionowych, będących kalką układów systemowych.

Dążenie do modernizacji systemowych uruchamia mechanizm związany z wyłanianiem się sytuacji nowych lub problematycznych, a tym samym kryzysowych. Wymagają one redefinicji znaczeń, gdyż niosą ze sobą element dezorganizacji, zmieniający stan zastany, dzięki któremu można wyjaśniać problemy 
i wprowadzać nowy porządek [Hall, Hewitt 1970]. Pojawianie się nowych jakości służyć ma opracowaniu koncepcji działania mającej na celu zredefiniowanie inkryminowanej sytuacji. Chodzi o to, by na bazie rutynowego tła społecznego dokonać rozpoznania aktualnych składników struktury społecznej i w sposób umiejętny i sprawny podjąć działania kreatywne, zmieniające w sposób ewolucyjny zastane elementy strukturalne na rzecz nowych, lepiej działających. Niezbędne jest przy tym podjęcie prac renowacyjnych w odniesieniu do zastanych, ale szwankujących elementów. Podejście to wzmacnia koncepcja Johna Loflanda [1976], w której dana sytuacja traktowana jest jako kontekst działania, miejsce dostępne aktorom społecznym w określonym czasie. W ujęciu Loflanda skalę sytuacji należy rozpatrywać w czterech wymiarach: osobowym (liczba ludzi zaangażowanych w sytuację), fizycznym (wyposażenie), przestrzeni oraz czasu. Ponieważ człowiek wykazuje skłonność do tworzenia schematów i wzorców, to wskazane wyżej wymiary można ująć w siedem skondensowanych form: role, grupy, organizacje, światy, otoczenia i społeczeństwa. Postrzeganie w ten sposób sytuacji społecznych jest spójne z potrzebą działania lokalnego i ugruntowuje sieciowo-systemowe ujmowanie procesu reintegracji społecznej.

Interakcjoniści postrzegają strukturę społeczną jako płaszczyznę negocjacyjną. Negocjowany porządek interakcyjny jest wskazywany między innymi w podejściu ukierunkowanym na aktywność aktorów społecznych. Podejście to jest reprezentowane przez Beckera, Tuckera, Denzina, Wellmana i Straussa oraz innych interakcjonistów, którzy traktują proces negocjowania przez podmiot swojego miejsca $\mathrm{w}$ splocie sytuacji pojawiających się $\mathrm{w}$ ustalonym porządku społecznym, jako kluczowy w kreowaniu własnego i społecznego dobrostanu. Aby to nastąpiło, niezbędna jest obecność podmiotu kreującego w sieci interakcji z innymi podmiotami, pełniącymi swoje funkcje społeczne w określonym miejscu i czasie. W trakcie interakcji przyporządkowywane są role oraz realizowane określone czynności. W procesie komunikacji dokonywana jest natomiast samoregulacja zachowań. W toku negocjacji znaczeń następuje robocze wypracowanie konsensusu polegającego na rekonstrukcji dotychczasowego przebiegu działań. W sytuacjach znanych, rozpoznawanych i oczekiwanych, aktorzy społeczni sytuujący się w roli obserwatorów nie są zmuszeni do interpretacji znaczeń. Jednakże w sytuacji aktywnego udziału, pozycjonują się w określonych zestawach interakcyjnych, określając swój status przez rejestrowanie wrażenia, jakie wywierają na innych i na sobie [Thompson, Fine 1999].

Projektowanie wspomagania readaptacyjnego w perspektywie sieciowo-systemowej wymaga zmiany dotychczasowego sposobu myślenia oraz świadomej rezygnacji z tunelowego modelu działania społecznego z wertykalnym układem struktur pomocowo-wspierających. U podstaw wspomagania lokalnego leży wymóg skonstruowania sieci stałej współpracy międzyinstytucjonalnej (sformalizowanej i długotrwałej), wzmacnianej obywatelską działalnością akcyjną (spontaniczną i krótkotrwałą). Koncepcyjnie działanie to nawiązuje do klasycznej i współczesnej pedagogiki społecznej i resocjalizacyjnej: koncepcji „sił społecznych” Heleny Radlińskiej, „spirali życzliwości” Stanisława Kawuli, „małych 
ojczyzn” propagowanych przez Wiesława Theissa, koncepcji „uspołecznionego systemu profilaktyki i resocjalizacji” Wiesława Ambrozika, „wielopasmowej teorii resocjalizacji z udziałem społeczeństwa" Andrzeja Bałandynowicza oraz „twórczej resocjalizacji” Marka Konopczyńskiego.

Promowane przeze mnie podejście sieciowo-systemowe osadzone jest na fundamencie idei klasteringu, spójnej z przyjętymi teoriami socjologicznymi, a wywodzącej się z obszaru nowoczesnego zarządzania organizacjami. Połączenie holistycznego podejścia sieciowo-systemowego z ideą i teorią klasteringu wiąże się z koniecznością zmiany sposobu projektowania działań readaptacyjno-reintegracyjnych oraz z przyjęciem zasady planowania kompleksowego i wielozakresowego. Istotą strategii sieciowo-systemowej jest jednoczesna, zazębiająca się kooperacja między wertykalnym układem współpracujących instytucji tego samego typu a horyzontalnym układem współpracujących ze sobą różnorakich instytucji: formalnych, nieformalnych, ekonomicznych, religijnych, wychowawczych, kulturalnych i socjalnych, działających na rzecz wspólnego beneficjenta, czyli ekswięźniów i ich rodzin.

Kooperujące układy strukturalne tworzą przestrzeń do wielorakich interakcji, twórczego myślenia, wytworzenia więzi zespołowych oraz wypracowują warunki do uruchomienia mechanizmu osłabiającego poczucie ryzyka. W toku wielostronnej współpracy uaktywniane są potencjały, w tym postawy i zdolności intelektualne niezbędne do optymalizowania rozwiązań o wielokierunkowym zastosowaniu.

Sieć międzyinstytucjonalnej współpracy środowiskowej na rzecz wspomagania reintegracyjnego ekswięźniów i ich rodzin podnosi znacznie skuteczność i efektywność działania wskutek pojawienia się gamy efektów: synergii, kuli śniegowej, stymulacji, zwiększonego poczucia bezpieczeństwa oraz spontaniczności. Zadania i oddziaływania przewidziane do realizacji muszą być jednak adekwatne do potrzeb wspomaganych podmiotów, z ukierunkowaniem na uzyskanie efektu stabilizującego, terapeutycznego oraz resocjalizująco-destygmatyzującego, a zarazem profilaktycznego. Tylko w ten sposób można wypracować u ekswięźniów i ich rodzin zdolność do eksdewiacyjnej autokreacji jednostkowej i grupowej [szerzej: Nowak 2016, 2011].

W przestrzeni społecznej, sieci współdziałania instytucjonalnego są wspólnie użytkowanym kapitałem (dobrem publicznym) oraz źródłem cennych zasobów ludzkich. Moc strategii sieciowo-systemowej tkwi we wzajemnym wpływie, jaki w sprzężeniu zwrotnym wywierają na siebie uczestnicy gry społecznej oraz w skłonności człowieka do naśladowania innych. Podejmowanie współpracy i współdziałania na rzecz osiągnięcia wspólnego celu daje zdecydowanie większy, pozytywny efekt niż w przypadku indywidualnego działania. Największy sukces odnoszą sieci najsilniej przejawiające cechy charakterystyczne dla „małego świata”, w których uczestnicy wykazują się kreatywnością i elastycznością myślenia oraz wspólnym poszukiwaniem nowych, innowacyjnych rozwiązań [Uzzi, Sapiro 2005; Watts, Strogatz 1998]. Przyjęcie omawianego podejścia i współgrającego z nim klastrowego modelu działania dają szansę na znaczny 
wzrost efektywności pomocy i wsparcia społecznego na rzecz byłych więźniów i ich rodzin. Należy podkreślić, że idea i teoria klasteringu autorstwa Michaela Portera, amerykańskiego badacza struktur gospodarczych, z powodzeniem wpisuje się w przyjętą podstawę teoretyczną. Porter [2001, s. 246] wprowadził pojęcie klastra, które zdefiniował jako

[...] geograficzne skupisko wzajemnie powiazanych firm, wyspecjalizowanych dostawców, jednostek swiadczacych ustugi, firm działajacych $w$ pokrewnych sektorach $i$ zwiazanych $z$ nimi instytucji (na przyktad uniwersytetów, jednostek normalizacyjnych i stowarzyszeń branżowych) w poszczególnych dziedzinach, konkurujacych między soba, ale również wspótpracujacych.

Struktura klastra oparta jest na kluczowym ogniwie, jakim jest instytucja zwana animatorem. Jej podstawowym zadaniem jest identyfikowanie innych instytucji gotowych do podjęcia kooperacji wokół wspólnego celu, rozpoznawania ich potrzeb i oczekiwań oraz wyznaczanie obszarów współpracy. Układy klastrowe wyodrębniane są na wspólnym obszarze geograficznym i są tworzone na podstawie dwóch mechanizmów: buttom-up (inicjatywy oddolne) oraz top-down (inicjatywy odgórne). Istota ich funkcjonowania opiera się na kooperacji instytucjonalnej wokół wspólnie realizowanego zadania. Jednoczesna, a zarazem wspólna ścieżka działania oraz silne i trwałe interakcje między uczestnikami sieci zorientowane są na wypracowanie i konsekwentne realizowanie konkretnego programu współpracy. Poprzez dostęp do nowych informacji, nowych umiejętności oraz optymalizacji metod działania, wytwarzany jest efekt synergii. Klaster przekształca się wówczas w system wyzwalający innowacyjność, pobudzający kreatywność i nowatorstwo [Palmen, Baron 2008]. Powiększając swoje potencjały, klastry stają się nośnikami wyspecjalizowanych zasobów, między innymi wiedzy i informacji, kadr oraz instytucji. Na bazie struktur klastrowych moga być tworzone lokalne sieci pomocy postpenitencjarnej i wspomagania reintegracyjnego, organizowane w środowisku życia ekswięźniów [szerzej: Nowak 2016].

Pewną ramową propozycją modernizacji dotychczasowego systemu pomocy postpenitencjarnej, opartej na podejściu sieciowo-systemowym jest model zmian strukturalnych, w którym centralnym elementem pozostałaby dotychczasowa Rada Główna ds. Społecznej Readaptacji i Pomocy Skazanym. Powoływałaby ona wojewódzkie Reintegracyjne Rady Terenowe (RRT), którym podlegałyby z kolei Powiatowe Biura Wsparcia Reintegracyjnego (PBWR-y). Miałyby one za zadanie tworzenie klastrów reintegracyjnych. W strukturze sieciowej pełniłyby rolę instytucji koordynującej współpracę z lokalnymi jednostkami samorządu terytorialnego oraz organizacjami pożytku publicznego.

Zadania instytucji koordynującej sieć wsparcia reintegracyjnego sprowadzałyby się głównie do:

a) gromadzenia informacji o możliwościach otrzymania przez ekswięźniów realnego, lokalnego wsparcia readaptacyjnego i przekazywania odpowiedniej 
bazy danych do zakładów karnych, która byłaby przydatna w pracy z więźniami przygotowywanymi do wyjścia na wolność;

b) inicjowanie działań w zakresie reedukacji i edukacji zawodowej ekswięźniów;

c) koordynowanie działań $\mathrm{w}$ obszarach wspomagających proces readaptacji społecznej: edukacji (współpraca z Centrami Kształcenia Zawodowego i Ustawicznego i uczelniami funkcjonującymi na danym terenie); zatrudnienia (PUP - gromadzenie ofert pracy dla byłych więźniów oraz kwalifikacyjnych kursów zawodowych); pomocy socjalnej (współpraca z instytucjami pomocy społecznej);

d) inicjowanie i koordynowanie działań ukierunkowanych na wsparcie kompetencyjne, finansowe i rzeczowe rodzin z problemem penitencjarnym;

e) monitorowanie losów ekswięźniów.

Należy podkreślić, że prezentowany model działania oparty jest na zasadzie dobrowolnego korzystania przez ekswięźniów i ich rodziny z oferowanego im wspomagania.

Działania instytucji koordynującej wzmacniane byłyby przez zatrudnionych lub pracujących woluntarystycznie, odpowiednio przeszkolonych, pozytywnie i trwale zintegrowanych społecznie ekswięźniów. Mogliby oni tworzyć także działające przy instytucji koordynującej — grupy samopomocowe dla osób opuszczających jednostki penitencjarne.

Jednym z kluczowych elementów sieci wspomagania reintegracyjnego byłyby zakłady karne, współpracujące z lokalnymi instytucjami koordynującymi. W zakresie przygotowania więźniów do wyjścia na wolność niezbędne byłoby powołanie odpowiednio przeszkolonych funkcjonariuszy do pełnienia funkcji więziennych koordynatorów pomocy postpenitencjarnej. Ich zadaniem byłoby gromadzenie danych diagnostycznych $\mathrm{w}$ zakresie potrzeb skazanych przygotowywanych do wyjścia na wolność, pozyskanych z wywiadów przeprowadzonych ze skazanymi oraz z innych źródeł, a także ich przekazywanie do lokalnych PBWR-rów. Użyteczne byłoby również utworzenie w zakładach karnych punktów informacyjnych dla osadzonych przygotowywanych do samodzielnego radzenia sobie w warunkach wolnościowych [szerzej: Nowak, 2015].

Niejako prototypem promowanego wyżej modelu działania postpenitencjarnego oraz pierwowzorem proponowanego PBWR-u jako koordynatora sieci wsparcia reintegracyjnego jest funkcjonujący już od kilku lat w Zabrzu, Społeczny Ośrodek Readaptacyjny dla osób opuszczających zakłady karne. Jest on prowadzony przez Fundację „Pomost”, która ma już na koncie sukcesy reintegracyjne swoich podopiecznych. Jest więc pomysłem sprawdzonym w działaniu - skutecznym i zwiększającym szanse na efektywne rozwiązywanie problemów trapiących ekswięźniów i ich rodziny. Aktualnie czynione są starania, by w ramach realizacji unijnego projektu Employment Bridge to the future, zabrzański SOR stał się modelem wdrażanym także w innych województwach. Inicjatywa ta niesie ze sobą nadzieję na realną poprawę funkcjonowania systemowego w zakresie pomocy postpenitencjarnej. 
Jestem głęboko przekonana, że sieciowo-systemowa koncepcja działań społecznych w obszarze wspomagania readaptacyjnego ekswięźniów i ich rodzin pozwoli na wygenerowanie skutecznych programów reintegracyjnych i zainspiruje badaczy tego bardzo trudnego obszaru działania społecznego do poszukiwania optymalnych rozwiązań również poza obszarem reprezentowanej dyscypliny naukowej. Wymaga to jednak przyjęcia szerokiej perspektywy interdyscyplinarnej, kreatywnej adaptacji idei i teorii klasteringu oraz oparcia nowego modelu na wynikach badań empirycznych nad osobowościowymi i środowiskowymi uwarunkowaniami powrotności do przestępstwa.

\subsection{Modele wspomagania reintegracyjnego, ekswięźniów i ich rodzin}

W kontekście rozważań podjętych w podrozdziale 4.2, niezbędne jest opracowanie nowych modeli działania w zakresie wspomagania reintegracyjnego wraz z oddziaływaniami zapewaniającymi wysoką skuteczność w zakresie uzupełniania deficytów kompetencyjnych ekswięźniów, którzy po długotrwałej izolacji więziennej, wskutek braku możliwości rejestrowania i doświadczania zmian w rzeczywistości społecznej, nie potrafią radzić sobie na wolności w sposób konstruktywny, gubiąc się w gąszczu narastających problemów i wyzwań. Dochodzi do tego jeszcze zagubione poczucie pewności siebie i stabilności,

[...] poczynając od niepewności co do wyboru własnych ról życiowych, własnych afiliacji, a także uznawanych wartości [Kwiatkowska 1994, s. 9].

Nie ulega wątpliwości, że dobrostan osobisty i rodzinny jest warunkowany posiadaniem spójnego i stabilnego systemu wartości, umiejętnością odgrywania przypisanych ról społecznych oraz wysokim poziomem kompetencji życiowych oraz innych, równie ważnych dyspozycji i zdolności. Wśród nich prym wiodą: konstruktywne radzenie sobie z problemami, sprawne komunikowanie się, zadaniowe radzenie sobie ze stresem czy też trafna identyfikacja zasobów osobowych (jednostkowych) i rodzinnych (grupowych).

Poczucie kompetencji jest ważną dyspozycją adaptacyjną oraz istotnym elementem zasobów wewnętrznych jednostki. Osoby posiadające wysokie poczucie kompetencji nadążają za zmianami zachodzącymi w środowisku oraz zmianami własnego statusu, bezproblemowo adaptując się do nowych warunków. Na znaczenie zdolności człowieka do konstruowania reprezentacji celów i przewidywania ich wyników wskazuje Albert Bandura [1989, s. 1175] w modelu „emergentnego, interaktywnego sposobu działania”. Podstawowym elementem konstrukcyjnym tego modelu jest teza, że człowiek wnosi swoisty 
wkład przyczynowy do własnej motywacji i działania w systemie triadic reciprocal causation, w którym znaczącą rolę odgrywają trzy sprzężone ze sobą czynniki: działanie, cechy osobowościowe, w tym poznawcze i afektywne oraz zdarzenia środowiskowe. Kluczową funkcję w kształtowaniu poczucia kompetencji pełnią zasoby, rozumiane przez S.E. Hobfolla [2006] zarówno jako przedmioty, warunki, jak i cechy osobowości oraz pokłady energii, które są cenione przez człowieka, przydatne mu w walce o przetrwanie lub będące środkiem do pozyskania innych zasobów niezbędnych do przetrwania. Poczucie kompetencji determinowane jest posiadaniem zarówno określonych zasobów wewnętrznych, tkwiących w sferze „Ja” i bezpośrednio dostępnych, jak i zewnętrznych, wspomagających, lokowanych poza granicami wewnętrznego „Ja” (m.in. wsparcie społeczne, status ekonomiczny czy zatrudnienie). Suma posiadanych przez jednostkę zasobów należy do jednych z najsilniejszych determinantów osiągania satysfakcji życiowej i subiektywnego dobrostanu [Diener, Fujita 1995]. Poczucie kompetencji w dużym stopniu warunkuje skuteczność radzenia sobie z problemami i pokonywania różnorakich trudności w życiu codziennym.

$\mathrm{W}$ procesie autoregulacji zachowań rolę wiodącą odgrywa z kolei poczucie koherencji, odzwierciedlające zgeneralizowaną orientację poznawczo-ewolucyjną jednostki wobec świata. Na poczucie koherencji składają się: zrozumialość - właściwość, dzięki której człowiek poznaje i rozumie działanie otoczenia; sterowalność - umiejętność radzenia sobie z otoczeniem przy użyciu posiadanych lub zdobytych zasobów; sensowność — przekonanie o celowości inwestowania w siebie i w swoje życie [Antonowski 1995]. W sytuacji utraty stabilności życiowej wysokie poczucie koherencji jest czynnikiem skłaniającym jednostkę do konstruktywnej aktywności. Dlatego też w świetle wyników badań I. Niewiadomskiej [2007, 2010, 2010a], oddziaływania podejmowane wobec więźniów i ekswięźniów powinny być ukierunkowane na umiejętne generowanie zmian w obrębie poddających się korekcji, względnie stałych, kognitywnych wymiarów osobowości, odpowiedzialnych za wzmacnianie: motywacji intencjonalnej (kryzys wartościowania, poczucie koherencji); doświadczania dystansu społecznego (poczucie oceny społecznej); przeżywania stresu (spostrzeganie sytuacji trudnej); zasobów odpornościowych w przezwyciężaniu problemów (poczucie koherencji, doświadczanie wsparcia społecznego).

W procesie stabilizacji sytuacji życiowej ekswięźniów nie do przecenienia jest wsparcie rodzinne oraz aktualne i potencjalne zasoby wspólnotowe, czyli zbiór wszystkich dostępnych rodzinie zasobów zewnętrznych, społeczno-środowiskowych oraz zasobów wewnętrznych sprzyjających jej rozwojowi, na które składają się zasoby relacyjne i komunikacyjne (zdolności adaptacyjne systemu rodzinnego, wzajemność relacji, wzorce komunikacyjne, normy wewnątrzrodzinne). Jednakże w polskiej rzeczywistości brakuje zarówno stosownych rozwiązań prawnych, jak i systemowych, które umożliwiałyby niesienie profesjonalnego wsparcia polidysfunkcyjnym rodzinom ekswięźniów. Nie są one bowiem objęte działaniami ukierunkowanymi na stabilizację i rozwój ich rozchwianych systemów. 


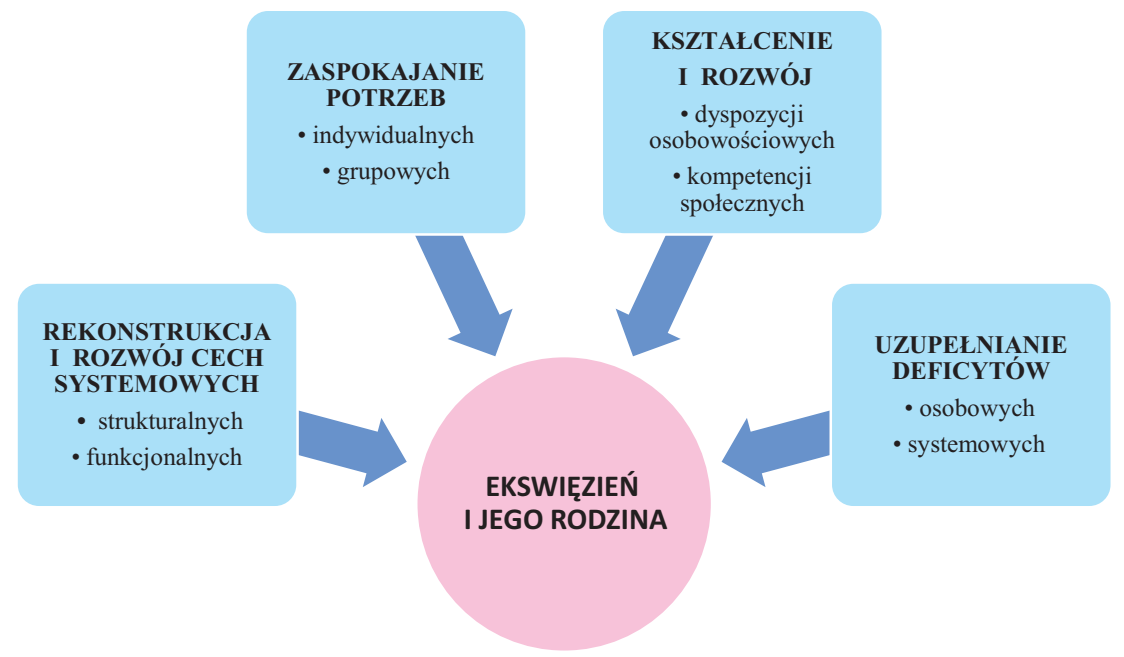

Rycina 1. Model pracy z ekswięźniem i jego rodziną

Źródło: opracowanie własne.

Działania resocjalizacyjne i readaptacyjne podejmowane wobec rodzin ekswięźniów powinny prowadzić do ich destygmatyzacji. Jest to proces niewątpliwie złożony i trudny, ale konieczny do uzyskania pozytywnych i trwałych efektów reintegracyjnych. Podstawowym założeniem w pracy z rodziną dotkniętą problemem przestępczości jest równoległe uzupełnianie braków, zaspokajanie potrzeb oraz rekonstrukcja i rozwój zarówno cech strukturalnych i funkcjonalnych rodziny, jak i dyspozycji osobowościowych i kompetencji społecznych jej członków - zaburzonych lub utraconych wskutek silnie obciążających psychicznie i nawarstwiających się sytuacji problemowych bądź też niedostatecznie wykształconych lub zaburzonych w procesie socjalizacji (ryc. 1).

Skutecznemu wyprowadzaniu ekswięźniów i ich rodzin z zapaści kryzysowej służyć może udzielanie im wsparcia kreująco-rozwojowego, niezbędnego w osiąganiu dyspozycji umożliwiających samodzielne funkcjonowanie i skuteczne radzenie sobie w sytuacjach trudnych. Należy jednak pamiętać, że podmioty wspomagania readaptacyjnego są wrażliwe na wszelką ingerencję zewnętrzną i trudne do zaktywizowania. Niechętnie, bardzo rzadko i nieregularnie uczestniczą $w$ terapii rodzinnej $z$ uwagi na ograniczenia finansowe i obawy przed stygmatyzacją społeczną. W sukurs przychodzą im twórcze metody i techniki pracy resocjalizacyjnej, które prowadzą jednostkę i całą grupę rodzinną ku autokreacji tożsamości społecznej. Metody twórczej resocjalizacji, a zwłaszcza Metoda Teatru Resocjalizacyjnego, dają podmiotom odziaływań asumpt do przełamywania barier środowiskowych oraz pozwalają na sukcesywne eliminowanie ich nieufności. Stanowią ponadto doskonałą płaszczyznę treningową w kształceniu kompetencji życiowych jednostek oraz dyspozycji i sprawności funkcjonowania systemów rodzinnych. Najistotniejsze jest jednak to, że w trakcie ich stosowania, aktywowany zostaje proces 
destygmatyzacji, czyli „nakładania” tożsamości nowej, funkcjonalnej, na starą, dysfunkcjonalną czy dewiacyjną, stanowiący warunek konieczny do zakończenia procesu ekskluzji społecznej [szerzej: Nowak 2011, Konopczyński 2006]. Teatr Resocjalizacyjny oraz inne metody interaktywne, jak też kierowane uczestnictwo ${ }^{11}$, mogą sprzyjać podwyższaniu samooceny i zdolności poznawczych ekswięźniów oraz służyć wyrównywaniu ich braków w zakresie komunikacji społecznej. Twórczy trening kompetencyjny umożliwia przecięcie toksycznych związków pomiędzy niedostatkiem doświadczeń społecznych (o różnej etiologii), deficytem kompetencji społecznych, nieprzystosowaniem do życia społecznego oraz zaburzeniami w pełnieniu funkcji społecznych [Nowak 2011; Smółka 2008; Matczak 2007].

Twórcze podejście do pracy z ekswięźniami i ich rodzinami, wyrasta z Goffmanowskiej wizji świata społecznego. Użycie przez Goffmana metafory teatralnej umożliwiło zastosowanie metodologii performatycznej do badania w zasadzie każdego przejawu ludzkiej aktywności. Goffman rozumiał performans jako interakcyjne działanie człowieka, zrytualizowane i skonwencjonalizowane przytłaczającymi zasadami zachowania, ukierunkowane na wywarcie określonego wrażenia na pozostałych uczestnikach interakcji. Należy jednak podkreślić, że ta swoista gra o zyski toczy się zawsze o tę samą stawkę - o wykreowanie i utrzymanie wiarygodnego wizerunku „Ja” jako kogoś, kto jest pewny siebie i swojego postępowania.

Wyniki prezentowanych badań własnych oraz cytowanych wcześniej badań nad rodzinami w kryzysie wieloproblemowym [Nowak 2011] ewidentnie wskazują na zasadność przyjęcia stabilizująco-rozwojowego kierunku wspomagania reintegracyjnego ekswięźniów i ich rodzin (ryc. 2). Model wspomagania reintegracyjnego ekswięźnia i jego rodziny uwzględnia równoległe oddziaływania: stabilizujące (pomoc socjalna, poradnictwo, terapia) oraz rozwojowe (aktywizowanie potencjałów osobowych i grupowych), prowadzące oba podmioty (skazanego i jego rodzinę) do pokryzysowej autokreacji tożsamości społecznej. Autokreacja jest procesem głębokiej samoświadomości, rozwijanym w toku autorefleksji przez podmiot wchodzący na ścieżkę autorskiego przekształcania siebie, zgodnego z wizją siebie w przyszłości [Pawlak 2009, s. 82]. W trakcie inicjowanej, zewnętrznej kreacji nowych cech psychospołecznych członków rodziny oraz podstawowych wymiarów systemu rodzinnego, wypracowywane są minireadaptacyjne zmiany [Nowak 2011; Niewiadomska 2011]. Wywołują one zmiany w postrzeganiu systemu rodzinnego z dysfunkcjonalnego na funkcjonalny, zarówno przez ekswięźnia, członków jego rodziny, jak i ich otoczenie społeczne.

11 A. Bandura pojęcie kierowanego uczestnictwa odnosił do udzielania pomocy w podejmowaniu działań modelowych (wzorcowych). 


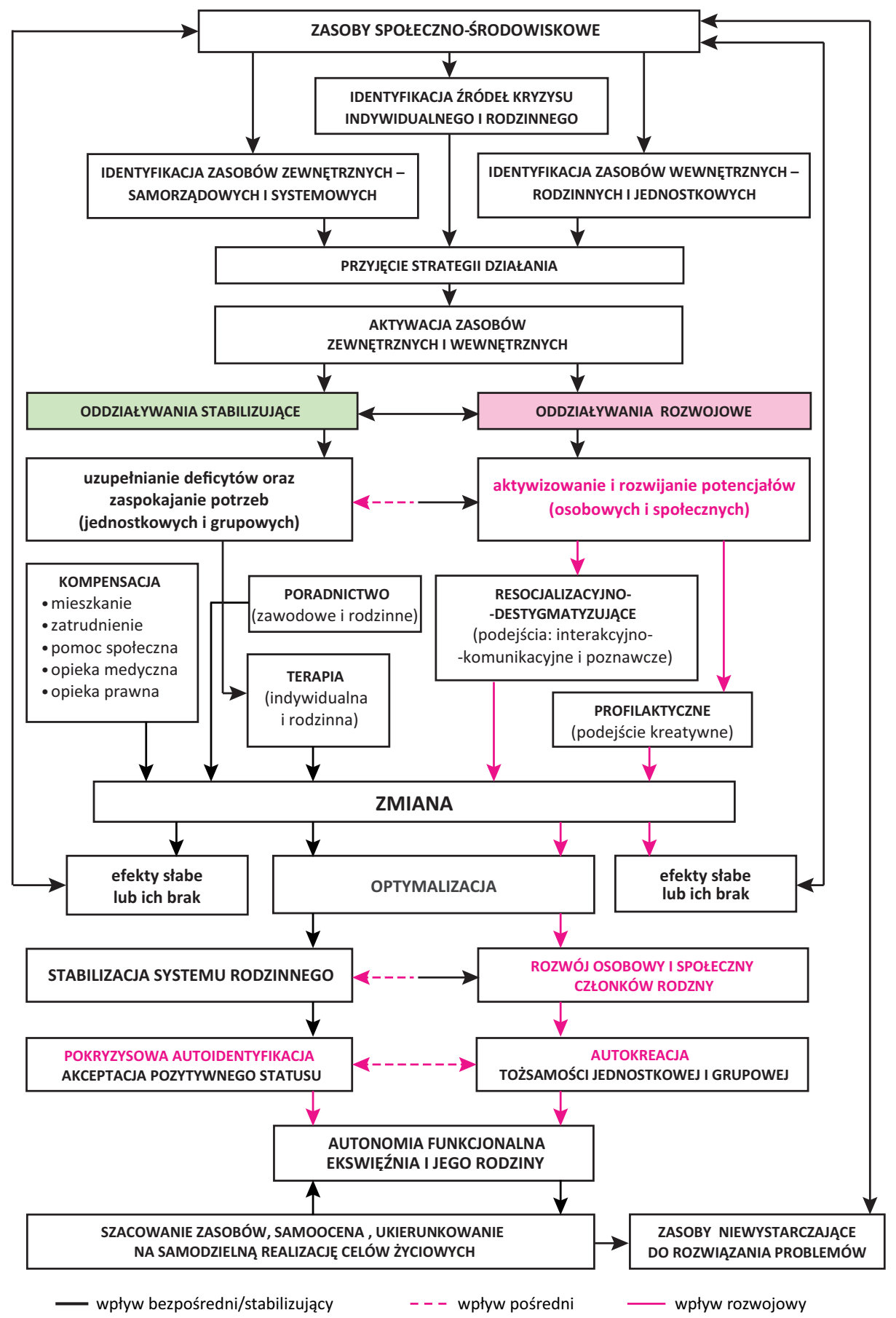

Rycina 2. Model stabilizująco-rozwojowego wspomagania ekswięźnia i jego rodziny Źródło: opracowanie własne. 
W zakresie wspomagania polidysfunkcyjnych rodzin z problemem przestępczości użyteczny jest także model oddziaływań resocjalizująco-destygmatyzujących [Nowak 2011, s. 294], który opiera się na założeniu, że eksdewiacyjna tożsamość rodziny może się ukonstytuować w toku trójfazowego procesu autokreacji nowej jakości jej funkcjonowania (ryc. 3).

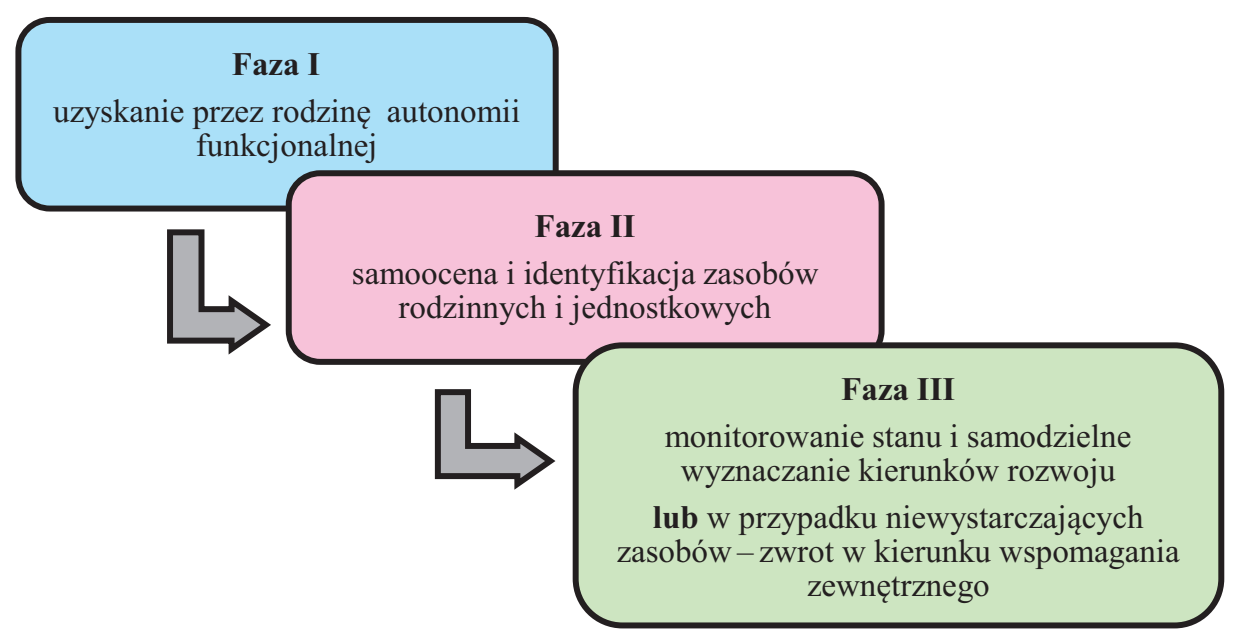

Rycina 3. Trójfazowy proces autokreacji nowej jakości funkcjonowania rodziny ekswięźnia Źródło: opracowanie własne.

W I fazie procesu autokreacji systemu rodzinnego wzmocnieni kompetencyjnie członkowie rodziny zmierzają ku autoidentyfikacji, czyli pełnej akceptacji nowego, pozytywnego statusu systemu rodzinnego, w efekcie czego następuje uzyskanie przez rodzinę autonomii funkcjonalnej. Faza II rozpoczyna się wtedy, gdy rodzina dokonuje samooceny i identyfikuje zasoby wewnętrzne, pozyskane lub/i wykształcone w procesie wspomagania społecznego. Faza III, wewnętrznie stabilizująca, dotyczy podejmowanych przez rodzinę działań monitorujących stan i jakość zasobów rodzinnych oraz dokonywania przez nią zmian, będących efektem swoistej ewaluacji dotychczasowych doświadczeń, jak również wyznaczania przez nią nowych kierunków rozwoju, a w przypadku stwierdzenia niedoboru zasobów wewnętrznych — oszacowania możliwości ich samodzielnej kompensacji lub podjęcia strategicznych decyzji dotyczących ponownego rozpoczęcia przez rodzinę poszukiwań wsparcia zewnętrznego Należy jednak brać pod uwagę fakt, że zmiany tożsamościowe dokonują się w procesie autokreacji opierającym się na autorefleksji.

Osiągnięcie przez rodzinę autonomii funkcjonalnej nie oznacza pozbycia się piętna rodziny polidysfunkcyjnej. Zmiana (poprawa) sytuacji życiowej zapewnić może względną samodzielność oraz zdolność do rozpoczęcia nowego etapu rozwojowego (ryc. 4). Rodzina wzmocniona kompetencyjnie i pozbawiona obciążającego piętna jest w stanie samodzielnie pokonywać kolejne kryzysy. 


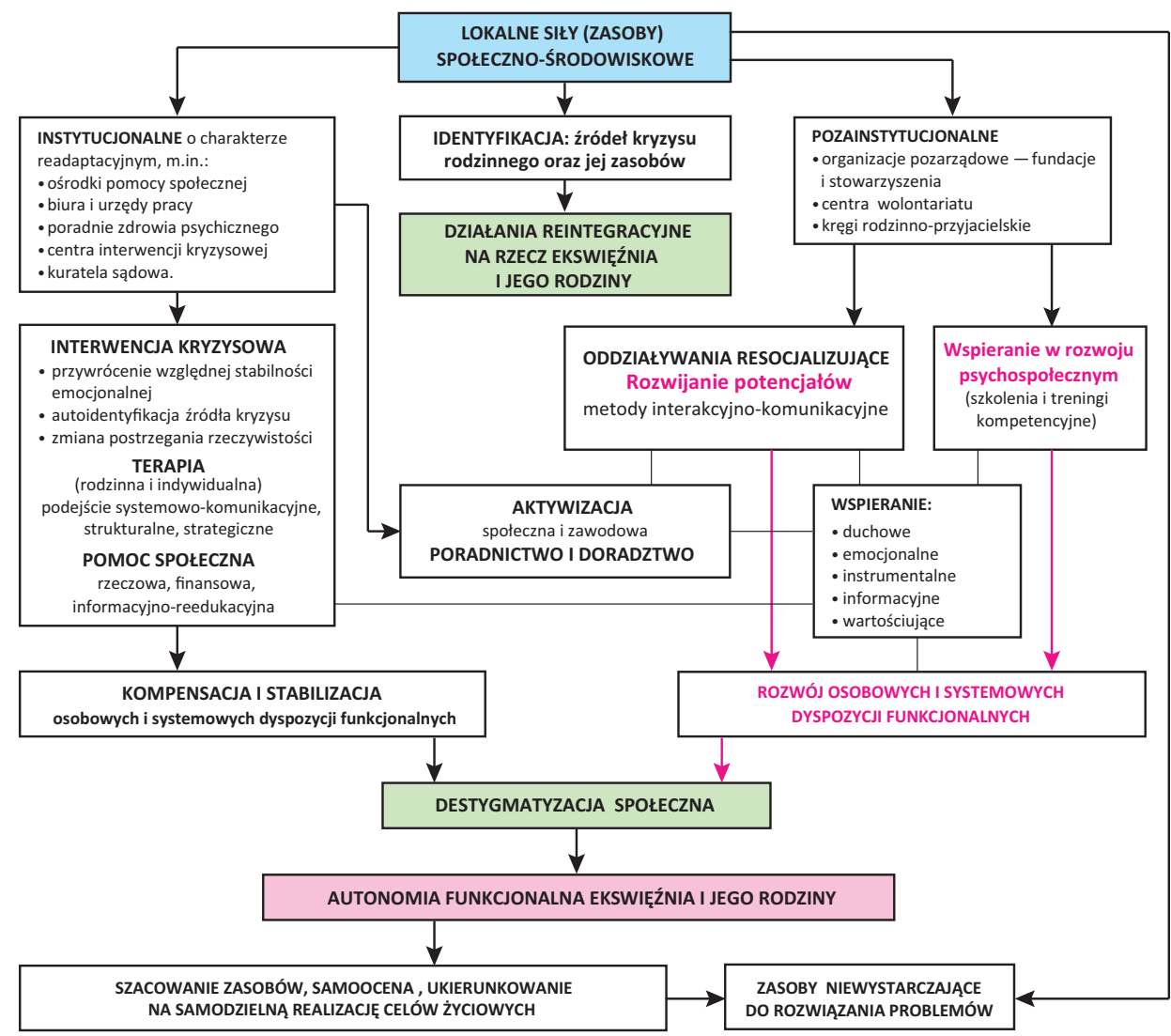

— wpływ bezpośredni/stabilizujący

- - - wpływ pośredni

wpływ rozwojowy

Rycina 4. Resocjalizująco-destygmatyzujący model wspomagania reintegracyjnego ekswięźnia i jego rodziny

Źródło: opracowanie własne.

Proces kształtowania nowej, rzeczywistej [Goffman 2007] i niedewiacyjnej tożsamości ekswięźnia i jego rodziny jest długotrwały, złożony i wymagający wielu zabiegów reintegracyjnych zarówno ze strony podmiotu wspomagającego, jak i wspomaganego. Szczególnie istotna jest tu ścieżka rozwojowa, która prowadzi podmiot do dokonywania niewymuszanych zewnętrznie zmian (w wiedzy, postawach i kompetencjach) w trakcie działań twórczych, owocujących nowym, post-dewiacyjnym postrzeganiem siebie i otoczenia.

Zaprezentowane wyżej modele są skonstruowane na wysokim poziomie ogólności i wymagają rozwinięcia w warstwie metodycznej. Mam jednak nadzieję, że treści i konkretne propozycje zamieszczone w książce wzbudzą refleksję i pobudzą do działania animatorów życia społecznego, zarówno praktyków, jak i decydentów, którzy aktywują proces niezbędnych modernizacji systemowych oraz zainicjują działania na rzecz powstania ogólnopolskiej sieci ośrodków wspomagania reintegracyjnego dla ekswięźniów i ich rodzin. 



\section{Nadzieja na lepsze jutro — zamiast zakończenia}

Rozpatrywanie nadziei w kontekście wspomagania reintegracyjnego ekswięźniów i ich rodzin jest w pełni uzasadnione. Nadzieja wyzwala bowiem moce twórcze i mobilizuje do walki o lepsze jutro. Jest autoteliczną i podstawową wartością, dzięki której człowiek nawet $\mathrm{w}$ dramatycznych momentach, w bólu i cierpieniu zachowuje sens życia.

W sytuacji beznadziei i niemożności nadzieja daje siłę przetrwania i wyzwala zdolność do pozytywnego działania oraz przekraczania własnych granic. Skłania do refleksji nad przyszłością, pozwala ją wizualizować i cierpliwie jej oczekiwać. Ale nadzieja może być też zwodnicza i złudna, może prowokować do biernego czekania na samoistną odmianę losu...

Na co mogę mieć nadzieję? — to jedno z trzech podstawowych pytań sformułowanych przez Immanuela Kanta. Niech na to pytanie odpowiedzą Ci, którzy karmią się nią w samotności, tkwiąc w okowach własnych słabości i niemożności:

Teraz jednak już wiem, że po wyjściu na wolność będę się starat znów odnowić relacje z córkami. Nie wiem, jak ja będę dalej żyt, ale chcę zapomnieć o tym, jak pitem i jak alkohol powoli wymazywat mi bliskich $z$ pamięci. Chce wrócić do pracy i żyć normalnie. Mam taka nadzieję, a nadzieja umiera przecież ostatnia... [S.I. — 52 lata, rozwiedziony, mieszkaniec miasta średniej wielkości, wykształcenie podstawowe, dwukrotny recydywista, wyroki skazujące za kradzieże]

Po moim wieloletnim odbyciu tego wyroku będę musiat pomóc sobie sam. $W$ Polsce nic mnie trzymać, nie będzie. Oczekuję zmian jedynie w prawie. Kogo w zakladzie interesuje, czy rodzina skazanego żyje w ubóstwie i jest nękana chorobami? [...] Obecnie uczęszczam do liceum (3 semestr) $i$ od kilku miesięcy jestem zatrudniony nieodpłatnie. Wierze, że przyda mi się to na wolności i pomoże znaleźć godziwa pracę. [P.K. - 44 lata, kawaler, mieszkaniec dużego miasta, wykształcenie podstawowe, trzykrotny recydywista, wyroki skazujące za zmuszanie do uprawiania prostytucji, kradzieże i zabójstwo] 
Jak skończę odbywanie wyroku, to wrócę do rodzinnego miasta i zamieszkam z żona. Dobrze by jednak byto, żeby przed końcem kary ktoś pomógt mi ogarnać wszystkie wnioski urzędowe i załatwit pracę. [D.F. - 31 lat, żonaty, mieszkaniec miasta średniej wielkości, wykształcenie podstawowe, trzykrotny recydywista, wyroki skazujące za kradzieże i jazdę samochodem pod wpływem alkoholu].

Mogę powiedzieć, że na pewno nie będę chciat tutaj wrócić, bo teraz posiadam pewna wiedzę z ukończenia kursu, ukończenia terapii. Myślę, że będę kontynuowat dalej te mitingi i spotkania. Wcześniej nie miatem wiedzy, co było przyczyna mojego zachowania, jak to wyglada, z czym to sie wiaże i tak dalej. Teraz już wiem i mam nadzieje, że wszystko się uda, że w końcu zobaczę świat na trzeźwo... [W.L. - 55 lat, mieszkaniec wsi, wykształcenie zawodowe, recydywista jednokrotny, wyroki skazujące za stosowanie przemocy domowej pod wpływem alkoholu]

Marzy mi sie już powrót do rodziny... Głównie rodzina, żeby była... Petna, bo ja tej rodziny swojej pierwotnej nie miatem, nie miałem ojca, tylko ojczyma... Poza domem też bytem znaczacy czas, dlatego chciatbym, aby ta moja obecna rodzina nie doświadczyła tego co ja. Żyje wcią̇ nadzieja, że mam do kogo jeszcze wrócić, że znów będa kolorowe święta, a nawet gdyby biednie byto, to i tak bytbym szczęśliwy. Ja juz powoli kombinuje, gdzie by się zatrudnić po wyjściu stąd, a to już i tak niedtugo, bo mam jeszcze siedem miesięcy odsiadki. Oj, jak ja sobie pobiegam po lesie, do utraty tchu. Proszę Pani, ja już czuję ten zapach wiosny, to stonko marcowe... ech! [S.P. - 35 lat, mieszkaniec małego miasta, wykształcenie zawodowe, recydywista jednokrotny, wyroki skazujące za kradzieże] 


\section{Bibliografia}

Adler R.B., Rosenfeld L.B., Proctor R.F. (2006). Relacje interpersonalne. Poznań: Rebis. Albański L. (2010). Wybrane zagadnienia z patologii społecznej. Jelenia Góra: Alex.

Aldwin C.E. (1994). Stress, coping, and development: An integrative perspective. New York: Guilford.

Alicke M.D. (2000). Culpable control and the psychology of blame. Psychological Bulletin, 226(4), 556-574.

Allport G.W., Vernon P., Lindzey G. (1951). Study of Values: Measuring the dominant interests in personality. Manual of directions. Cambridge: Houghton Mifflin Company.

Allport G.W., Vernon P. (1931). A test for personal values. The Journal of Abnormal and Social Psychology, 26(3), 231-248.

Amato P.R. (1993). Children's Adjustment to Divorce: Theories, Hypotheses, and Empirical Support, Journal of Marriage and the Family, 55, 23-38.

Ambrozik W. (2007). Czynniki społecznej readaptacji byłych przestępców. W: B. Urban, J.M. Stanik (red.), Resocjalizacja: teoria i praktyka, T. 2. Warszawa: Pedagogium/PWN.

Ambrozik W. (2016). Pedagogika resocjalizacyjna. W stronę uspołecznienia systemu oddziaływań. Kraków: IMPULS.

Anderson S.A., Sabetelli R.M. (1999). Family interaction. Boston: Allyn \& Bacon Press.

Archer M.S. (2000). Being Human: The Problem of Agency. Cambridge: Cambridge University Press.

Archer M.S. (2012). The Reflexive Imperative in Late Modernity. Cambridge: Cambridge University Press.

Augoustinos M., Walker I., Donaghue N. (2006). Social cognition: An integrated introduction. London: Sage.

Bakken L., Romig C. (1994). The relationship of perceived family dynamics to adolescents' principled moral reasoning. Journal of Adolescent Research, 9, 442-457.

Baltes M.M., Baltes P.B. (1990). Psychological perspectives on successful aging: The model of selective optimization with compensation (1-34). W: M.M. Baltes, P.B. Baltes (ed.), Successful aging: Perspectives from the behavioral sciences. New York: Cambridge University Press.

Baltes P.B. (1987). Theoretical propositions of life — span developmental psychology: On the dynamics between growth and decline. Developmental Psychology, 23, 611-626.

Bałandynowicz A. (2019). Resocjalizacja z udziałem społeczeństwa. Konteksty antropologiczno-filozoficzne. Wyd. 3, Warszawa: Wolters Kluwer.

Barnes G.M., Farrell M.P. (1992). Parental Support and Control as Predictors of Adolescent Drinking, Delinquency, and Related Problem Behaviors. Journal of Marriage and the Family, 54(4), 763-776. 
Bartoszek A., Kocka K., Zielonka E., Łuczyk M. i in. (2016). The problem of the use of drugs among seniors living in the home environment. Journal of Education, Health and Sport, 6(6), 235-244.

Beard J., Johnson J., Kemp J. (2003). Proposal to Reduce Recidivism Rates in Texas. Houston, TX: Earl Carl Institute for Legal and Social Policy.

Beard J., Johnson M., Kemp J. (2003). Proposal to reduce recidivism rates in Texas. Earl Carl Institute for Legal and Social Policy,Inc. http:/www.tsulaw.edu/centers/ECI/ pubs_files/Criminal\%20Justice/Recidivism\%20Position\%20Paper\%20-\%20PDF $\% 5 B$ BFinal $\% 5$ D.pdf.

Beck A.T. (1999). Prisoners of Hate: The Cognitive Basis of Anger, Hostility and Violence. New York: Harper Collins.

Becker H.S. (1963). Outsiders: Studies in the sociology of deviance. Oxford, England: Free Press Glencoe.

Beckman L. (1970). Effect of student's performance on teachers and observers attributions of causality. Journal of Educational Psychology, 61, 76-82.

Bednarski G. (2011). Postawa a zachowanie Mazowszan wobec osób, które odbyły karę pozbawienia wolności. Praca Socjalna, 1, 50-66.

Belniak K. (2014). Poczucie kontroli u sprawców przestępstw agresywnych. Acta Universitatis Lodziensis, 18, 31-44.

Berne E. (1961). Transactional Analysis in Psychotherapy. A Systematic Individual and Social Psychiatry. New York: Grove Press.

Berntsen D., Rubin D.C. (2002). Emotionally charged autobiographical memories across the life span: The recall of happy, sad, traumatic and involuntary memories. Psychology and Aging, 17, 636-652.

Berntsen D. (2010). The unbidden past: Involuntary autobiographical memories as a basic mode of remembering. Current Directions in Psychological Science, 19(3), 138-142.

Bielska B. (2016). Praktyki ukrywania. O pułapkach, pokusach i pożytkach z badań niejawnych. Przegląd Socjologii Jakościowej, 12(3), 70-87.

Bless H., Fiedler K., Strack F. (2004). Social cognition: How individuals construct social reality. Hove: Psychology Press.

Blumer H. (2007). Interakcjonizm symboliczny: perspektywa i metoda. Kraków: Nomos.

Bodenhausen G.V., Kramer G.P., Süsser K. (1994). Happiness and stereotypic thinking in social judgement. Journal of Personality and Social Psychology, 66, 621-632.

Bodenhausen G.V. (1988). Stereotypic biases in social decision making and memory: Testing process models of stereotype use. Journal of Personality and Social Psycho$\log y, 55,726-737$.

Bojkało W., Koperek J. (2013). Rodzina jako instytucja społeczna z perspektywy rozwoju społeczeństwa obywatelskiego. Roczniki Nauk o Rodzinie, 5(60), 63-81.

Borecka-Bernat D. (2014). Osobowościowe determinanty agresywnej strategii rozwiązywania konfliktów przez gimnazjalistów. Szkoła Specjalna, 4, 245-261.

Borecka-Biernat D. (1992). Style wychowania w rodzinie a agresywne zachowania dzieci. Acta Universitatis Wratislaviensis. Prace Psychologiczne, 26, 125-141.

Borecka-Biernat D. (2006). Strategie radzenia sobie młodzieży w trudnych sytuacjach społecznych. Psychospołeczne uwarunkowania. Wrocław: Uniwersytet Wrocławski.

Bosworth D.L., Dawkins D.J., Stromback T. (1996). The Economics of the Labour Market. United Kingdom: Pearson Education Limited. 
Bowen E., Gilchrist E.A. (2004). Do court — and self-referred domestic violence offenders share the same characteristic? A preliminary comparison of motivation to change, locus of control and anger. Legal and Criminological Psychology, 9, 279-294.

Bowen E., Gilchrist E.A., Beech A. (2005). An examination of the impact of community - based rehabilitation on the offending behavior of Male domestic Violence offenders and the characteristics associated with recidivism. Legal and Criminological Psychology, 10, 189-209.

Bowlby J. (1969). Grief and mourning in infancy and early childhood. Psychoanalytic Study of the Child, 15, 9-52.

Bowlby J. (1969a). Attachment and Loss. Vol. 1: Attachment. New York: Basic Books.

Bowlby J. (1980). Attachment and Loss. Vol. 3: Loss, Sadness and Depression. New York: Basic Books.

Bowlby J. (2007). Przywiązanie. Warszawa: PWN.

Boyes M.C., Allen S.G. (1993). Styles of parent-child interaction and moral reasoning in adolescence. Merrill-Palmer Quarterly, 39, 551-570.

Bradshaw J. (1994). Zrozumieć rodzinę. Warszawa: IPZ i PTP.

Bruner J.E. (1992). Życie jako narracja. Kwartalnik Pedagogiczny, 37, 3-17.

Brzezińska I.A. (2005). Psychologiczne portrety człowieka. Gdańsk: GWP.

Buck L.Z., Walsh W.F., Rothman G. (1981). Relationship between parental judgement and socialization. Youth and Society, 13, 91-116.

Burt C.D., Kemp S., Grady J.M., Conway M.A. (2000). Ordering autobiographical memories. Memory, 8, 323-332.

Caballero J., Dankner M., Harper R., Kane S. et al., (2011). Sent „home” with nothing: the deportation of Jamaicans with mental disabilities. Washington D.C: Georgetown University Law Centre, Human Rights Institute.https://scholarship.law.georgetown. edu/cgi/viewcontent.cgi (article $=1005 \&$ context $=$ hri_papers. Accessed 19 August 2011.

Cabała P. (2007). Wprowadzenie do prakseologii. Przegląd zasad skutecznego działania. Kraków: Wydawnictwo Akademii Ekonomicznej w Krakowie.

Carroll A., Durkin K., Hattie J., Houghton S. (1997). Goal Setting among Adolescents: A Comparison of Delinquent, At-Risk and Not-At-Risk Youth. Journal of Educational Psychology, 89 (3), 441-450.

Chomczyński P. (2013). Sposoby radzenia sobie z emocjami wśród wychowanków zakładów poprawczych w Polsce. Studia Edukacyjne, 26, 185-204.

Chomczyński P. (2017). Wykorzystanie materiałów wizualnych w badaniach nad społeczną percepcją osób, które popełniły przestępstwo. Wnioski metodologiczne z badań nad stygmatyzacją. Archiwum Kryminologii, 39, 369-389.

Ciosek M. (2003). Psychologia sądowa i penitencjarna. Warszawa: Wydawnictwo Prawnicze LexisNexis.

Clemmer D. (1950). Observations on Imprisonment as a Source of Criminality. Journal of Criminal Law and Criminology, 41(3), 311-319.

Contreras L., Molina V., Cano M.C. (2011). In search of psychosocial variables linked to the recidivism in young offenders. The European Journal of Psychology Applied to Legal Context, 3, 77-88.

Conway M.A., Pleydell-Pearce C. (2000). The construction of autobiographical memories in the self-memory system. Psychological Review, 107, 261-288.

Conway M.A. (1996). Autobiographical knowledge and autobiographical memories. Cambridge: University Press. 
Cood H. (1998). Prisoners' Families: The „Forgotten Victims”. Probation Journal, 45, $148-153$.

Cox F.N., Leaper P.M. (1961). Assessing some Aspects of the Parent-child Relationships. Child Development, 32, $821-830$

Cupryjak M. (2016). Paradygmaty w perspektywie zmian społecznych. Zarys problemu. Rocznik Andragogiczny, 23, 251-254.

Czapiga A. (1994). Przyczyny rozbicia rodziny a warunki życia dzieci i samotnych matek (19-24). W: A. Senejko (red.), Psychologia rozwoju człowieka. Wybrane zagadnienia. Prace Psychologiczne, XXXVII, Wrocław: Wyd. UW.

Czarkowski J.J., Strzelec M. (2020). Praca badawcza penitencjarysty. Warszawa: Episteme.

Czykwin E. (2007). Stygmat społeczny, Warszawa: PWN.

Damasio A. (2000). Tajemnica świadomości. Jak ciało i emocje współtworzą świadomość. Poznań: Rebis.

Deater-Deckard K., Dodge K.A. (1997). Externalizing behavior problems and discipline revisited: nonlinear effects and variation by culture, context and gender. Psychological Inquiry, 8, 161-175.

Dennet D. (1991). Consciousness Explained. Boston: Little Brown Co.

Diener E., Fujita F. (1995). Resources, personal strivings and subjective well-being: A nomothetic and idiographic approach. Journal of Personality and Social Psycho$\log y, 68,926-935$.

Douglas J.D. (1973). Understanding Everyday Life. London: Routledge \& Kegan Paul.

Drozda-Senkowska E. (1982). Umiejscowienie kontroli a spostrzeganie nieoczekiwanych informacji. Studia Psychologiczne, 20(2), 89-99.

Drwal J. (1979). Opracowanie kwestionariusza Delta do pomiaru poczucia kontroli. Studia Psychologiczne, 18(1), 67-82.

Dyczewski L. (1994). Rodzina, społeczeństwo, państwo. Lublin: Wydawnictwo Towarzystwa Naukowego KUL.

Dykcik W. (2003). Stygmatyzacja przestępcy w kontekście kary i szansy dla jego powrotu do społeczeństwa (318-329). W: T. Sołtysiak, J. Sudar-Malukiewicz (red.). Zjawiskowe formy patologii społecznych oraz profilaktyka i resocjalizacja młodzieży. Bydgoszcz: Wydawnictwo Akademii Bydgoskiej.

Dzarnowska W., Klawiter A. (2006). Mózg i jego umysły. Poznań: Zysk i S-ka.

Dzielska A. (2015). Picie alkoholu (176-186). W: J. Mazur (red.). Zdrowie i zachowania zdrowotne młodzieży szkolnej w Polsce na tle wybranych uwarunkowań socjodemograficznych. Warszawa: Instytut Matki i Dziecka.

Dzierzyńska-Breś S. (2016). Sytuacja społeczna rodzin osób pozbawionych wolności. Poznań: Wydawnictwo Naukowe UAM.

Dzierzyńska-Breś S. (2020). The economic situation and social interactions of prisoners' families. Interdisciplinary Contexts of Special Pedagogy, 29, 193-210.

Ehrenberg R.G., Smith R.S. (2000). Modern Labor Economics, 7. edition. New York, Addison-Wesley Longman.

Farnicka M., Grzegorzewska I. (2016). Intrapersonalne korelaty agresywności u młodych ludzi - uwarunkowania podejmowania roli agresora lub ofiary. Dziecko Krzywdzone. Teoria, badania, praktyka, 15(2), 147-170.

Farrington D.P. (1996). Individual, family and peer factors in the development of delinquency (21-56). In: S.C.R. Hollin, K. Howells (ed.), Clinical approaches to working with young offenders. Chichester: Wiley. 
Feather N.T. (1996). Reactions to Penalties for an Offense in Relation to Authoritarianism, Values, Perceived Responsibility, Perceived Seriousness and Deservingness. Journal of Personality and Social Psychology, 71, 571-587.

Fidelus A. (2012). Determinanty readaptacji społecznej skazanych. Warszawa: Wyd. UKSW.

Fidelus A. (2013). Stygmatyzacja byłych więźniów jako skutek procesu społecznej readaptacji. Forum Pedagogiczne, 1, 107-135.

Fila-Jankowska A. (2009). Samoocena autentyczna. Co ukrywamy sami przed sobą. Warszawa: Wyd. SWPS „Academica”.

Filer R.K., Hamermesh D.S., Rees A.E. (1996). The Economics of Work and Pay, 6. edition. New York: Harper Collins College Publishers.

Fiske S.T., Taylor S.E. (1991). Social Cognition. New York: McGraw Hill, Inc.

Fletscher G.J., Ward O. (1988). Attribution theory and processes: A cross cultural perspective (230-244). In: M.H. Bond (ed.), The cross-cultural challenge to social psychology. Newbury Park, CA: Sage.

Florczykiewicz J. (2013). Poczucie marginalności osadzonych odbywających karę pozbawienia wolności i wybrane jego uwarunkowania. Sprawozdanie z badań. Profilaktyka Społeczna i Resocjalizacja, 22, 153-187.

Florczykiewicz J. (2013). Poczucie marginalności osadzonych odbywających karę pozbawienia wolności i wybrane jego uwarunkowania. Sprawozdanie z badań. Profilaktyka Społeczna i Resocjalizacja, 22, 153-187.

Försterling F. (2005). Atrybucje. Podstawowe teorie, badania i zastosowanie. Gdańsk: GWP.

Frąckiewicz J.L. (2001). Systemy sprawnego działania: teoria i praktyka. Warszawa: Fundacja Pomocy „Antyk”.

Fronczak A. (2017). Agresja dzieci w świetle teorii społeczno-poznawczej. Resocjalizacja Polska, 13, 73-85.

Gannon T. (2009). Current cognitive distortion theory and research: An internalist approach to cognition. Journal of Sexual Aggression, 15, 225-246.

Gasparski P. (1979). Rola przekonania o sterowności w podejmowaniu decyzji sekwencyjnych. Zeszyty Naukowe Instytutu Psychologii UW, 14, 76-90.

Gasparski P. (1989). Internal-external control of reinforcement and some probabilistic and thinking indices. Studia Psychologica, 31(3), 215-222.

Gasparski P. (1997). Wiara w sukces i gotowość do działania na przekór porażkom. Psychologia Wychowawcza, 5, 398-412.

Gendreau P., Goggin C., \& Law, M. (1997). Predicting prison misconducts. Criminal Justice and Behavior, 24, 414-431.

Gigerenzer G. (1991). From tools to theories: A heuristic of discovery and cognitive psychology. Psychological Review, 98(2), 254-267.

Glick B., Gibbs C.J. (2011). Trening zastępowania agresji. Warszawa: Wydawnictwo Instytutu „Amity”.

Goffman E. (1963). Stigma. Notes on the management of spoiled identity. New York: Penguin.

Goffman E. (2005). Piętno. Rozważania o zranionej tożsamości. Gdańsk: GWP.

Goffman E. (2007). Piętno. Rozważania o zranionej tożsamości. Gdańsk: GWP.

Goffman E. (2009). Człowiek w teatrze życia codziennego. Warszawa: PIW.

Goldscheider F.K., Goldscheider C. (1989). Family structure and conflict: Nest-leaving expectations of young adults and their parents. Journal of Marriage and the Family, 51, 87-97. 
Greenwald A.G., McGhee D.E., Schwarz J. (1998). Measuring Individual Differences in Implicit Cognition: The Implicit Association Test. Journal of Personality and Social Psychology, 74, 1464-1480.

Hagan J., Simpson J., Gillis A.R. (1987). Class in the Household: A Power-Control Theory of Gender and Delinquency. American Journal of Sociology, 92, 788-816.

Hagan J. (1989). Modern criminology, crime, criminal behavior and its control. New York: Mac Graw-Hill.

Hall P.M., Hewitt J.P. (1970). The quasi-theory of communication and the management of dissent. Social Problems, 18, 17-27.

Han-Ilgiewicz N. (1995). Pisma, szkice, artykuły, rozprawy. Warszawa: WSPS.

Harris S. (2012). Pejzaż moralny. W jaki sposób nauka może okiełznać wartości? Stare Groszki: CiS.

Harwas-Napierała B. (2006). Komunikacja interpersonalna i jej kształtowanie jako istotny wymiar jakości życia rodziny. W: T. Rostowska (red.). Jakość życia rodzinnego. Wybrane zagadnienia (29-43). Łódź: Wyd. Naukowe Wyższej Szkoły informatyki.

Hastrof A., Schneider D., Polefka J. (1970). Person perception. Reading. MA: Addison-Wesley.

Hay, J. (2010). Analiza transakcyjna dla trenerów, przeł. E. Wójcik. Kraków: Wyd. Transmisja.

Heatherton T.F., Kleck R., Hebl M.R., Hull J. (2008). Społeczna psychologia piętna. Warszawa: PWN.

Heckhausen H., Schmalt H-D., Schneider K. (1985). Achievement motivation in perspective. New York: Academic Press, s. 127.

Heider F., Simmel M. (1944). An experimental study of apparent behaviour. American Journal of Psychology, 57, 243-259.

Heider F. (1958). The Psychology of Interpersonal Relations. New York: Wiley.

Helms M.M. (2006). Encyclopedia of Management. Detroit: Thompson Gale.

Herman J.L. (1998). Przemoc: uraz psychiczny i powrót do równowagi. Gdańsk: GWP.

Hesse E. (1999). State of Mind with Respect to Attachment and its Effects on Parenting Behavior. In: J. Cassidy, P. Shaver (eds.), Handbook and Attachment: Theory, Research and Clinical Applications. New York: Guilford Press.

Hewstone M., Klink A. (1994). Intergruppenatributtion (73-104). In: F. Frösterling, J. Steinsmeler-Pelsler (eds.), Attributtionstheorie. Göttingen, Germany: Hogrefe.

Hobfoll S.E. (2006). Stres, kultura i społeczność. Psychologia i filozofia stresu. Gdańsk: GWP.

Hoffman M.L., Salzstein H.D. (1967). Parent discipline and the child's moral development. Journal of Personality and Social Psychology, 5, 45-57.

Hołda Z., Postulski K. (2005). Kodeks karny wykonawczy. Komentarz. Gdańsk.

Horner K.L. (1996). Locus of control, neuroticism, and stressors: combined influences on reported physical illness. Personality Individual Differences, 21(2), 195-204.

Hornik I. (2010). Dlaczego kobiety uciekają z domu i stają się bezdomne? Gdańsk.

Hume D. (2005). Traktat o naturze ludzkiej. Warszawa: Altheia.

Jackson L.A., Lewandowski D.A., Fleury R.E., Chin P.P. (2001). Effects of affect, stereotype consistency, and valence of behavior on casual attributions, The Journal of Social Psychology, 141(1), 31-48.

Jasiński J. (1986). W sprawie rozumienia terminu „patologia społeczna”. Państwo i Prawo, 5. 
Jaworowska A., Matczak A. (2003). Test Niedokończonych Zdań Rottera RISB. Podręcznik. Warszawa: PTP.

Jaworska A. (2008). Tożsamość więźnia jako determinant wykluczenia społecznego. W: J. Nowak (red.). Meandry wykluczenia społecznego. Warszawa: WSP TWP.

Jędrzejczak M., Boroń I. (2003). Rodzinne i środowiskowe czynniki narkomanii wśród młodzieży poborowej. Medycyna Rodzinna, 1, 44-46.

Johnson S.M. (1993). Humanizowanie narcystycznego stylu. Warszawa: Agencja Wydawnicza Jacek Santorski.

Johnson S.M. (2012). Style charakteru. Poznań: Zysk i S-ka.

Jones E.E., Davis K.E. (1965). From acts to disposition: The attribution process in person perception. In: L. Berkowitz (ed.). Advances in experimental social psychology (Vol. 2, 219-266). New York: Academic Press.

Juvonen J. (1991). Deviance, perceived responsibility and negative peer reactions. Developmental Psychology, 27, 672-681.

Kaja B.N. (2010). Psychologia wspomagania rozwoju. Zrozumieć świat życia człowieka. Sopot: GWP.

Kalisz T. (2017). Znęcanie się nad osobą pozbawioną wolności: bezpieczeństwo osobiste skazanych. Wrocławskie Studia Erazmiańskie, 11, 225-243.

Kamiński M.M. (2006). Gry więzienne. Tragikomiczny świat polskiego więzienia. Warszawa: Oficyna Naukowa.

Kassin S.M., Pryor J.B. (1985). The development of attribution processes (3-34). In: J.B. Pryor, J. Day (eds.). The Development of Social Cognition. New York: Springer Verlag.

Kassin S.M. (1979). Consensus information, prediction and casual attribution: A review of the literature and issues. Journal of Personality and Social Psychology, 37, 1966-1981.

Kavas A.B. (2009). Self-Esteem and Health-Risk Behaviors among Turkish Late Adolescents. Adolescence, 44(173), 121-129.

Kieszkowska A. (2012). Inkluzyjno-katalaktyczny model reintegracji społecznej skazanych. Konteksty resocjalizacyjne. Kraków: Impuls.

Kitsuse J.I. (1962). Societal Reaction to Deviant Behavior: Problems of Theory and Method. Social Problems, 9, 247-256.

Klimczak J. (2017). Prizonizacja a skazani na karę dożywotniego pozbawienia wolności. Archiwum Kryminologiczne, 39, 231-248.

Kohlberg L. (1984). Essays on moral development: The psychology of moral development (Vol. 2). San Francisco: Harper and Row.

Kohut H. (1977). The restoration of the self. New York: International Universities Press.

Konopczyński M. (2006). Metody twórczej resocjalizacji. Warszawa: PWN.

Kornacka-Skwara E. (2002). Psychologiczna analiza systemów rodzinnych mężczyzn bezrobotnych (praca doktorska napisana pod kierunkiem M. Braun-Gałkowskiej), Lublin: KUL.

Kotarbiński T. (1955). Traktat o dobrej robocie, Łódź: Łódzkie Towarzystwo Naukowe.

Kozdrowicz E., Pilch T. (1984). Rodzina wielkomiejska matki samotnej jako środowisko wychowawcze (163-171). W: Z. Tyszka (red.). Rodzina a struktura społeczna. Bydgoszcz: BTN.

Krasowicz G., Kurzyp-Wojnarska A. (1987). Społeczne wyznaczniki poczucia kontroli następstw zdarzeń. Psychologia Wychowawcza, 5, 39-48. 
Krueger R.F., Caspi A., Moffitt T.E., Silva P.A., McGee, R. (1996). Personality traits are differentially linked to mental disorders: a multitrait-multidiagnosis study of an adolescent birth cohort. Journal of Abnormal Psychology, 105, 299-312.

Kubinowski D. (2010). Jakościowe badania pedagogiczne. Filozofia. Metodyka. Ewaluacja, Lublin: wyd. UMCS.

Kubinowski D. (2017). Badanie jakościowe jako poznanie idiomatyczne. Jakościowe Badania Pedagogiczne, t. II, 2, 65-78.

Kudlińska I. (2011). Stygmatyzacja społeczna jako perspektywa teoretyczno-badawcza (na przykładzie badań nad stygmatyzacją ludzi biednych). Acta Universtiatis Lodziensis. Folia Socjologica, 38, 51-72.

Kuhn T. (1968). Struktura rewolucji naukowych. Warszawa: PWN.

Kujawa M. (2011). Rozwój w kierunku zachowań sprzyjających nieprzystosowaniu społecznemu. W: K. Biel, J. Kusztal (red.). Dziecko zagrożone wykluczeniem. Elementy diagnozy, działania profilaktyczne i pomocowe. Kraków: Wyd. WAM.

Kupiec H. (2008). Rozmiary i społeczno-demograficzne uwarunkowania zachowań ryzykownych uczniów szkół gimnazjalnych (358-371). W: M. Konopczyński, B.M. Nowak (red.). Resocjalizacja - ciągłość i zmiana. Warszawa: Wyd. Pedagogium.

Kusiak K., Szewczyk L., Włoszczak-Szubzda A. (2017). Czynniki biopsychospołeczne a częstość spożywania alkoholu wśród młodzieży. Studia i Prace Pedagogiczne. Rozprawy i Materiaty (Pedagogika), 4, 99-135.

Kwak A. (2000). Rodziny rekonstruowane — problemy i zagrożenia (78-99). W: E. Milewska, A. Szymanowska (red.). Rodzice i dzieci. Psychologiczny obraz sytuacji problemowych. Warszawa: CMPPP MEN.

Kwaśniewski J. (1991). Zakres pojęcia i problematyki patologii społecznej. W: T. Szymanowski (red.). Patologia społeczna. Wybrane problemy. Warszawa: Wyd. WSPS.

Kwiatkowska H. (red.). (1994). Ewolucja tożsamości pedagogiki. Warszawa: IHNOiT.

Lauer R.H., Lauer J.C. (1991). The Long-term Relational Consequences of Problematic Family Backgrounds. Family Relations, 40, 286-290.

Lelental S. (2017). Kodeks karny wykonawczy. Komentarz. Wyd. 6. Warszawa: C.H. BECK.

Lemert E. (1967). Human deviance, social problems and social control. Englewood Cliffs, N.J. Prentice-Hall.

Levy K.N., Blatt S.J., Shaver P.R. (1998). Attachment Styles and Parent Representations. Journal of Personality and Social Psychology, 74(2), 407-419.

Lewandowska-Walter A. (2006). Czy macocha musi być zła? Społeczne spostrzeganie kobiety pełniącej rolę rodzica w rodzinie zrekonstruowanej (110-118). W: T. Rostowska, J. Rostowski (red.). Wokół wychowania. Rola rodziny i szkoły w procesie socjalizacji dziecka. Łódź: WSI.

Lewin K., Lippitt R., White R.K. (1939). Patterns of aggressive behavior in experimentally created „social climates”. Journal of Social Psychology, 10, 271-299.

Liberska H. (2007). Kształtowanie się tożsamości a styl wychowania w rodzinie (53-75). W: B. Harwas-Napierała, H. Liberska (red.). Tożsamość a współczesność. Nowe tendencje i zagrożenia. Poznań: UAM.

Lofland J. (1976). Doing social life: a qualitative study of human interaction In natural settings. New York: Willey.

Lowen A. (1983). Narcissism: Denial of the true self. New York: Macmillan.

Ludwig K.B., Pittman J.F. (1999). Adolescent prosocial values and self-efficacy in relation to delinquency, risky sexual behavior, and drug use. Youth and Society, 30, 461-482. 
Łukaszewski W. (1997). Prywatne koncepcje natury ludzkiej i ich funkcje regulacyjne. Kolokwia Psychologiczne, 6, 69-84.

MacCall G.J. (2003). Interaction. In: L.T. Reynolds, N.J. Herman-Kinney (eds.). Handbook of symbolic Interactionism, Lanhann: Rowman and Littlefield Publishers.

Mace J.H. (2007). Involuntary memory: Concept and theory (1-19). In: J.H. Mace (ed.). Involuntary memory. Malden, MA: Blackwell.

Mahler M. (1968). On human symbiosis and the vicissitudes of individuation. New York: International Universities Press.

Maier F. (1982). Zur Herrschaftslogik des sozialen Handelns: eine kritische Rekonstruktion von Max Webers Gesellschaftstheorie. Königstein: Forum Academicum, Ts. 1.

Major B., O'Brien L. (2005). The Social Psychology of Stigma. Annual Review of Psycho$\log y, 56,393-421$.

Malec J. (1986). Patologia społeczna jako zjawisko. Projekt definicji. Państwo i Prawo, 4.

Maqsud M., (1980). The relationship of sense of powerlessness to antisocial behavior and school achievement. The Journal of Psychology, 105, 147-150.

Marczak M. (2005). Świat w percepcji więźniów i więźniarek. Opieka. Wychowanie. Terapia, 3/4, 39-41.

Marek A. (2014). Prawo karne. Wyd. 5, Warszawa: C.H. Beck.

Margasiński A. (2010). Współuzależnienie i syndrom DDA w kontekście teorii systemów rodzinnych Bowena. Terapia Uzależnienia i Wspótuzależnienia, 1, 14-20.

Margasiński M. (1996). Analiza psychologiczna systemów rodzinnych z chorobą alkoholową. Częstochowa: Wyd. WSP.

Margasiński M. (2010). Rodzina alkoholowa z uzależnionym w leczeniu. Kraków: Impuls.

Maruszewski T., (2005). Pamięć autobiograficzna. Gdańsk: GWP.

Maruszewski T., Ścigała E. (1998). Emocje — aleksytymia — poznanie. Poznań: Humaniora.

Marzec W. (2011). Granice (teorii) społecznych światów. Przegląd Socjologii Jakościowej, VII, 1.

Mass. V. (2007). Integracja sensoryczna a neuronauka — od narodzin do starości. Warszawa: Fundacja Innowacja WSS-E.

Matczak A. (2007). Kwestionariusz Kompetencji Społecznych. Warszawa: PTP.

Mazur J., Tabak I., Małkowska-Szkutnik A., Ostaszewski K. i in., (2006). Czynniki chroniące młodzież 15-letnią przed podejmowaniem zachowań ryzykownych. Raport z badań HBSC. Warszawa: Instytut Matki i Dziecka.

Mądrzycki T. (1977). Psychologiczne prawidłowości kształtowania się postaw. Warszawa: WSiP.

McArtur L.A. (1977). The how and what of why: Some determinants and consequences of casual of attributions. Journal of Personality and Social Psychology, 22, 171-193.

McFarland C., Ross M. (1982). The impact of casual attributions on effective reactions to success and failure. Journal of Personality and Social Psychology, 43, 937-946.

Messick S. (1996). Bridging cognition and personality in education: The role of style in performance and development. European Journal of Personality, 10, 353-376.

Meyer W.U., Försterling F. (1993). Die Atributtionstheorie (175-216). In: D. Frey, M. Irle (eds.). Theorien der Sozialpsychologie (t. 2). Kognitive Theorien), Bern, Switzerland: Huber.

Meyer W.U., Reisenzein R., Schützwohl A. (1997). Toward a Process Analysis of Emotions: The Case of Surprise. Motivation and Emotion, 21(3), 254-274. 
Michalska A., Michalski D. (2020). Zachowania niepożądane w zakładach karnych. Wybrane zagadnienia, Olsztyn: Wyd. AEH.

Międzynarodowy standard zarządzania jakością ISO 9000, p. 3.2.14, https://www.iso. org/obp/ui/\#iso:std:iso:9000:ed-3:v1:en.

Mill J.S. (1882). A System of Logic, Ratiocinatively and Inductive. New York: Harper \& Brothers Publishers.

Miller D.T., Ross M. (1975). Self-Serving Biases in the Attribution of Causality: Fact or Fiction? Psychological Bulletin, 82(2), 213-225.

Miller D.T., Norman S.A., Wright E. (1979). Distortion in person perception as a consequences of the need for effective control. Journal of Personality and Social Psychology, 36, 598-607.

Moll J., de Oliveira-Souza R., Zahn R. (2008). The neural basis of mortal cognition: Sentiments, concepts, and values. Ann NY Acad. Sci, 1124(1), 161-180.

Moll J., Zahn R., de Oliveira-Souza R., Krueger F. \& Grafman J. (2005). Opinion: The neural basis of human moral cognition. Nat Rev Neurosis, 6(10), 799-809.

Napora E., Kozerska A. (2010). Styl wychowania i komunikacji w percepcji młodzieży wychowywanej przez samotne matki. Studia Psychologia UKSW, 10, 67-85.

Nazarko K., Bielska D.E. (2012). Picie alkoholu - częste zachowanie ryzykowne młodzieży szkół ponadgimnazjalnych. Przegląd Lekarski, 69(10), 878-883.

Nęcka E., Orzechowska J., Szymura B. (2007). Psychologia poznawcza, Warszawa: PWN.

Niedźwieńska A. (2000). Pamięć autobiograficzna (111-126). W: A. Gałdowa (red.). Tożsamość człowieka, Kraków: UJ.

Niewiadomska I. (2007). Osobowościowe uwarunkowania skuteczności kary pozbawienia wolności. Lublin: KUL.

Niewiadomska I., Chwaszcz J. (2010). Jak skutecznie zapobiegać karierze przestępczej? Lublin: EFS (drukarnia „TEKST”).

Niewiadomska I. (2010a). Znaczenie zasobów psychospołecznych w procesie resocjalizacji (57-65). W: L. Pytka B.M. Nowak (red). Problemy współczesnej resocjalizacji. Warszawa: WEMA.

Nisbet R.E., Caputo C., Legant P., Maracek J. (1973). Behavior as seen by the actor and as seen by the observer. Journal of Personality and Social Psychology, 27, 154-165.

Nisbett R.E., Borgida E. (1975). Attribution and the psychology of prediction. Journal of Personality and Social Psychology, 32, 932-943.

Nowak B.M. (2011). Rodzina w kryzysie. Studium resocjalizacyjne. Warszawa: PWN.

Nowak B.M. (2015). Reintegracja społeczna skazanych w wybranych państwach Unii Europejskiej. Resocjalizacja Polska, 10, 55-79.

Nowak B.M. (2016). Interdyscyplinarne, sieciowo-systemowe podejście do procesu readaptacji i reintegracji społecznej osób skazanych i ich rodzin. Studia Edukacyjne, 42, 233-249.

Nowak B.M. (2017). Hierarchia wartości osób wykluczonych społecznie. Komunikat z badań. Pedagogika Społeczna, 1(63), 139-159.

Nowak B.M. (2017a). Kapitał ludzki i społeczny w procesie reintegracji społecznej ekswięźniów i ich rodzin (31-45). W: I. Mudrecka (red.). Resocjalizacja, readaptacja i reintegracja społeczna - problemy, programy i perspektywy rozwoju komunikacji. Warszawa: Pedagogium.

Nowak B.M. (2017b). Poczucie lokalizacji kontroli u skazanych powracających do przestępstwa a postrzeganie przez nich własnych rodzin pochodzenia. Przeglad Badań Edukacyjnych, 25(2), 163-182. 
Nowak B.M. (2018). At risk of social exclusion labor market disadvantage of ex-convicts — polish casus. Przegląd Badań Edukacyjnych, 2(27), 85-96.

Nowak B.M. (2019). Praca jako czynnik chroniący ekswięźniów przed powrotnością do przestępstwa i wykluczeniem społecznym, Annales Universitatis Mariae Curie-Skłodowska, sectio J - Paedagogia-Psychologia, 32(3), 289-306.

Nowak B.M. (2019a). Praca szansą skazanych na pomyślną reintegrację społeczną. Postawy pracodawców wobec ekswięźniów poszukujących zatrudnienia - komunikat z badań. Probacja, 1, 13-32.

Nowak B.M. (2019b). (Nie)bezpieczna rodzina - kalejdoskop (dys)funkcji, Nauki O Wychowaniu. Studia Interdyscyplinarne. 9(2), 33-55.

Nowak B.M., Banasiak A., Górnicka B., Zajęcka B. (2019c). Zagrożenia życia rodzinnego w ocenie badanej młodzieży (410-467). W: R. Bera, S.M. Kwiatkowski (red.). Młodzież wobec współczesnych zagrożeń w życiu społecznym. Warszawa: Wyd. APS.

Nowicki S., Strickland B.R. (1973). A Locus Of Control Scale For Children. Journal of Consulting and Clinical Psychology, 40, 148-154.

Obuchowska I. (2009). Rodzice i style wychowania. Część 2. Remedium, 9, 6-7.

Oleś P., Oleś M. (1981). Zagadnienie wartości w psychologii humanistycznej A.H. Maslowa i C.R. Rogersa. Roczniki Filozoficzne, 29 (4), 141-161.

Oliwa-Ciesielska M., Przymeński A. (2010). Zapobieganie bezdomności - teoretyczne i praktyczne inspiracje (75-92). W: Ł. Browarczyk, M. Dębski (red.). Forum o bezdomności bez lęku. Gdańsk.

Opora R. (2011). Ewolucja niedostosowania społecznego jako rezultat zmian w zakresie odporności psychicznej i zniekształceń poznawczych. Gdańsk: Wyd. Uniwersytetu Gdańskiego.

Ostafińska-Molik B., Wysocka E. (2015). Style wychowania w rodzinie pochodzenia w percepcji młodzieży z zaburzeniami internalizacyjnymi i eksternalizacyjnymi analiza zależności. Resocjalizacja Polska, 9, 97-119.

Ostafińska-Molik B., Wysocka E. (2016). Rodzina w doświadczeniach młodzieży gimnazjalnej w kontekście przemian rodziny współczesnej: refleksja teoretyczna i empiryczne egzemplifikacje. Przegląd Pedagogiczny, 1, 56-76.

Oyserman D. (2001). Self-concept and identity. In: A. Tesser \& N. Schwarz. The Blackwell Handbook of Social Psychology, 499-517.

Palmen L., Baron M. (2008). Przewodnik dla animatorów inicjatyw klastrowych w Polsce. Warszawa: PARP.

Palmer E.J., Hollin C.R. (1996). Sociomoral reasoning, perception of own parenting and self-reported delinquency. Personality and Individual Differences, 21, 175-182.

Palmer E.J., Hollin C.R. (1997). The influence of perceptions of own parenting on sociomoral reasoning, attributions for criminal behaviour, and self-reported delinquency. Personality and Individual Differences, 23, 193-197.

Paszkiewicz A. (2017). Stygmatyzacja społeczna osób odbywających karę pozbawienia wolności — zarys problematyki. Przegląd Więziennictwa Polskiego, 97, 55-74.

Patterson G.E. (1982). Coercive family Processes. Eugene, OR: Castalia.

Patterson G.R., DeBaryshe B.D., Ramsey E. (1989). A developmental perspective on antisocial behaviour. American Psychologist, 44(2), 329-335.

Pawlak J. (2009). Autokreacja. Psychologiczna analiza zjawiska i jego znaczenie dla rozwoju człowieka. Kraków: Wyd. Ignatianum.

Penc J. (1997). Leksykon biznesu. Warszawa: Agencja Wydawnicza Placet. 
Piaget J. (1981). Równoważenie struktur poznawczych. Warszawa: PWN.

Pilch T., Baumann T. (2018). Zasady badań pedagogicznych. Strategie ilościowe i jakościowe. Warszawa: Żak.

Plopa M. (2007), Psychologia rodziny. Teoria i badania. Kraków: Impuls.

Plopa M. (2012). Rodzice a młodzież. Teoria i metoda badania. Warszawa: VIZJA PRESS \& IT.

Podgórecki A. (1969). Patologia życia społecznego. Warszawa: PWN.

Porter M. (2001). Porter o konkurencji. Warszawa: PWE.

Pospiszyl I. (2012). Patologie społeczne. Warszawa: PWN.

Powers S.I. (1988). Moral judgement development within the family. Journal of Moral Education, 17, 209-219.

Praszkier R. (1988). W głąb szczerości. Warszawa: Nasza Księgarnia.

Przetacznikowa M., Makieło-Jarża G. (1977). Psychologia wychowawcza, społeczna i kliniczna. Warszawa: WSiP.

Pyszczyński T.A., Greenberg J. (1987). Toward an integration of cognitive and motivational perspectives on social inference: A biased hypothesis - testing model (297340). In: L. Berkowitz (ed.). Advances in experimental social psychology. San Diego, CA: Academic Press.

Pytka L., Nowak B.M. (red.), (2010). Problemy współczesnej resocjalizacji. Warszawa: WEMA.

Rembowski J. (1972). Więzi uczuciowe w rodzinie. Warszawa: PWN.

Renken B., Egeland B., Marvinney D., Mangelsdorf S., Sroufe L.A. (1989). Early childhood antecedents of aggression and passive-withdrawal in early elementary school. Journal of Personality, 57(2), 257-281.

Reykowski J. (1986). Motywacja, postawy prospołeczne a osobowość. Warszawa: PWN. Robins R.W., Spranca M.D., Mendelsohn G.W. (1996). The actor-observer effect revisited: Effects of individual differences and repeated social interactions on actor and observer attributions. Journal of Personality and Social Psychology, 71, 375-389.

Robinson-Riegler G., Robinson-Riegler B. (2004). Cognitive psychology. Boston: Pearson Education.

Rode M. (2013). Style myślenia przestępczego. Podstawy teoretyczne i diagnostyczne. Warszawa: Diffin.

Rokeach M., Ball-Rokeach S. (1989). Stability and change in American value priorities 1968-1981. American Psychologist, 44(5), 775-784

Rokeach M. (1973). The nature of human values. New York: The Free Press.

Rokeach M. (1979). Value theory and communication research: review and commentary (7-28). In: D. Nimmo (ed.), Communication Yearbook 3. New Brunswick: Transaction Books.

Ross M., Sicoly F. (1979). Egocentric biases in availability and attribution. Journal of Personality and Social Psychology, 35, 817-829.

Ross L. (1977). The intuitive psychologists and this shortcomings: Distortions in the attribution process. Advances in Experimental Social Psychology, 10, 174-221.

Rostowski J. (2003). Style przywiązania a kształtowanie się związków interpersonalnych w rodzinie. W: I. Janicka, T. Rostowska (red.). Psychologia w służbie rodziny. Łódź: Wydawnictwo Uniwersytetu Łódzkiego.

Rotter J.B. (1966). Generalized expectancies for internal versus external control of reinforcement. Psychological Monographs, 80 (pełna zawartość). 
Rotter J.B. (1975). Some problems and misconceptions related to the construct of internal versus external control of reinforcement. Journal of Consulting and Clinical Psychology, 43, 56-68.

Rubacha K. (2008). Metodologia badań nad edukacją. Warszawa: Wydawnictwa Akademickie i Profesjonalne.

Rubin D.C. (1995). Introduction (1-15). In: D.C. Rubin (ed.). Remembering our past: Studies in autobiographical memory. Cambridge: Cambridge University Press,.

Rutter M., Giller H., Hagell A. (1998). Antisocial behavior by young people: A major new review. Cambridge: Cambridge University Press.

Rymsza M. (2012). Pracownicy socjalni i praca socjalna w Polsce. Między służbą społeczną a urzędem. Warszawa: Instytut Spraw Publicznych.

Schur E.M. (1971). Labeling deviant behavior. New York: Harper \& Row.

Schwartz S.H., Bilsky W. (1987). Toward a universal psychological structure of human values. Journal of Personality and Social Psychology, 53(3), 550-562.

Schwartz S.H. (1992). Universals in the content and structure of values: Theory and empirical tests in 20 countries. Advances in experimental social psychology, 25, 1-65.

Seligman M. (1975). Helplessness: On Depression, Development, and Death. San Francisco: W.H. Freeman.

Semin G.R., Fiedler K. (1991). The linguistic category model, its bases, applications and range. European Review of Social Psychology, 2, 1-50.

Serot N.M., \& Teevan R.C. (1961). Perception of the parent-child relationship and its relation to child adjustment. Child Development, 32, 373-378.

Shibutani T. (1994). Reference Group as Perspectives. In: N. Herman, L. Reynolds (eds.). Symbolic Interaction, An Introduction to Social Psychology. New York: Dix Hills.

Siemaszko A. (1993). Granice tolerancji. O teoriach zachowań dewiacyjnych. Warszawa: PWN.

Sigda K., Matusiak R. (2016). Dysfunkcjonalność współczesnej rodziny skutkiem różnego rodzaju uzależnień. Społeczeństwo i Rodzina, 46 (1), 143-154.

Sikora J. (1971). Znaczenie barw w życiu człowieka i w warunkach izolacji więziennej. Przegląd Penitencjarny i Kryminologiczny, nr 1.

Simmons J.I. (1965). Public Stereotypes of Deviants. Social Problems, 13, 223-232.

Sinclair L., Kunda Z. (1999). Reactions to a Black professional Motivated inhibition and activation of conflicting stereotypes. Journal of Personality and Social Psycho$\log y, 77,885-904$.

Sitarczyk M. (2004). Nieletni sprawcy zabójstw. Sylwetki psychologiczne. Lublin: Wyd. UMCS.

Smithmyer C.M., Hubbard J.A., Simons R.F. (2000). Proactive and reactive aggression in delinquent adolescents: relations to aggression outcome expectancies. Journal of Clinical Child Psychology, 29, 86-93.

Smółka P. (2008). Kompetencje społeczne. Metody pomiaru i doskonalenia umiejętności interpersonalnych. Kraków: Wolters Kluwer Polska.

Speicher B. (1994). Family patterns of moral judgement during adolescence and early adulthood. Developmental Psychology, 30, 624-632.

Stankiewicz L. (2002). Zrozumieć bezdomność, Olsztyn.

Stępień A.B. (2001). Wstęp do filozofii. Wydanie IV rozszerzone. Lublin: Towarzystwo Naukowe KUL.

Storms M.D. (1973). Videotape and the attribution process: Reversing actors' and observers' points of view. Journal of Personality and Social Psychology, 27(2), 165-175. 
Strauss A.L. (1982). Social Worlds and Legitimation Processes. In: N. Denzin (ed.). Studies in Symbolic Interaction, 4. Greenwich: JAI Press.

Strelau J. (2000). Psychologia. Podręcznik akademicki, t. II. Gdańsk: GWP.

Strelau J. (2002). Psychologia różnic indywidualnych. Warszawa: Scholar.

Strzelczyk K. (2010). Poczucie kontroli u skazanych uczestniczących w więziennej terapii uzależnień. Studia z Psychologii KUL, 16, 75-89.

Sullivan H.S. (1953). The Interpersonal Theory of Psychiatry. New York: Norton.

Sutherland E.H., Cressey D.R., Luckenbill D.F. (1992). Principles of Criminology. Wyd. 11. New York: Dix Hills.

Sykes G.M., Matza D. (1957). Techniques of Neutralization: A Theory of Delinquency. American Sociological Review, 22(6), 664-670.

Szczepaniak K. (2012). Zastosowanie analizy treści w badaniach artykułów prasowych - refleksje metodologiczne. Acta Universitatis Lodziensis. Folia Sociologica, 42, 83-112.

Szczepanik R., Miszewski. K. (2016). Wpływ długoterminowego uwięzienia na rodziny więźniów — stan wiedzy i zaniedbane kierunki badań. Profilaktyka Społeczna i Resocjalizacja, 30, 53-95.

Szczepanik R., Śliwerski A. (2017). Obietnice bez pokrycia. Etyczne i prawne granice (nie)ujawniania informacji o przestępstwie w badaniach naukowych i psychoterapii. Przegląd Badań Edukacyjnych, 1(24), 151-172.

Szczepanik R. (2015). Stawanie się recydywistą. Kariery instytucjonalne osób powracających do przestępczości. Łódź: Wydawnictwo Uniwersytetu Łódzkiego.

Szczepańska H. (1992). Żony alkoholików. Warszawa: IPZiT.

Szechner R. (2007). Performatyka. Wstęp. Przeł. T. Kubikowski. Wrocław: Instytut im. Jerzego Grotowskiego.

Sztumski J. (1995). Czy możemy mówić o „patologii społecznej”? W: T. Sołtysiak (red.). Zjawiska patologii społecznej. Uwarunkowania, rozmiary, profilaktyka, prognozy. Bydgoszcz: WSP.

Szymanowska A. (2000). Dziecko w rodzinie niepełnej (58-78). W: E. Milewska, A. Szymanowska (red.). Rodzice i dzieci. Psychologiczny obraz sytuacji problemowych, Warszawa: CMPPP MEN.

Szymanowska A. (2008). Uwarunkowania agresji interpersonalnej wśród młodzieży (372-385). W: M. Konopczyński, B.M. Nowak (red.). Resocjalizacja - ciągłość i zmiana. Warszawa: Wyd. Pedagogium.

Szymanowski T., Świda Z. (1998). Kodeks karny wykonawczy. Komentarz. Warszawa.

Taylor D.A., Altman I. (1987). Communication in interpersonal relationships: Social penetration theory. In: M.E. Miller (ed.). Interpersonal process: New directions in communication research (257-277). Sage Publications, Newbury Park.

Terelak J.F., Steckiewicz M. (2007). Charakterystyka stresu ekologicznego i różnice indywidualne w radzeniu sobie $\mathrm{z}$ nim na przykładzie osób przebywających w więzieniu. Studia Ecologiae i Bioethicae, 5, 23-41.

Thompson L., Fine G.A. Socially shared cognition, affect and behavior: a review and integration. Personality and Social Psychology Review, 3(4), 278-302.

Thompson R.A. (1999). Early Attachment and Later Development. In: J. Cassidy, P. Shaver (eds.). Handbook and Attachment: Theory, Research and Clinical Applications. New York: Guilford Press.

Tillman W.S., Carver C.S. (1980). Actors' and observers' attributions for success and failure: A comparative test of predictions from Kelley's cube, self-serving bias 
and possibility bias formulations. Journal of Experimental Social Psychology, 16, $18-32$.

Toroń B. (2013). Przestępczość skazanych kobiet i mężczyzn w perspektywie biograficznej. Kraków: Impuls.

Tulving E. (1985). How many memory systems are there? American Psychologist, 40, $385-398$.

Tulving E. (2002). Episodic memory. From mind to brain. Annual Review of Psychology, $53,1-25$.

Turecka M. (2005). Czynniki zwiększające ryzyko i zapobiegające przemocy seksualnej. Seksuologia Polska, 3/2, 45-51.

Tyszkowa M. (1974). Charakterystyka typowych środowisk wychowawczych: rodzinnego, szkolnego i pozaszkolnego. Problemy Opiekuńczo-Wychowawcze, 3, 2-7.

Urban B. (2000). Zaburzenia w zachowaniu i przestępczość młodzieży. Kraków: Wyd. UJ.

Urban B. (2005). Zachowania dewiacyjne w interakcjach rówieśniczych. Kraków: Wydawnictwo Uniwersytetu Jagiellońskiego.

Urban B. (2010). Współczesne teorie zaburzeń w zachowaniu. W: L. Pytka, B.M. Nowak (red.), Problemy współczesnej resocjalizacji. Warszawa: Wyd. Pedagogium.

Uzzi B., Sapiro J. (2005). Team Assembly Mechanisms Determine Collaboration Network Structure and Team Performance, http://www.kellogg.northwestern.edu/ faculty/uzzi/ftp/guimera_et_al_science_2-2005_final.pdf [dostęp: 6.06.2015].

Van Knippenberg A., Dijksterhuius A., Vermeulen D. (1999). Judgement and memory of a criminal act: The effects of stereotypes and cognitive load. European Journal of Social Psychology, 29, 191-201.

Vossenkuhl W. (2012). Możliwość dobra. Etyka w XXI wieku. Kraków: Wyd. WAM.

Walęcka-Matyja K. (2009). Polimorficzny obraz struktury rodziny w świetle współczesnej literatury psychologicznej. Acta Universitatis Lodziensis. Folia Psychologica, 13, 29-40.

Walker L., Taylor J.H. (1991). Family interactions and the development of moral reasoning. Child Development, 62, 264-283.

Walkowiak R. (2011). Prakseologiczne zasady sprawnego działania. Zeszyt Naukowy Ekonomia i Zarzadzanie, 1, 21-34.

Walters G.D., White T.W. (1989). Lifestyle criminality from a developmental standpoint. American Journal of Criminal Justice, 13, 257-278.

Walters C.D. (2006a). Appraising, researching and conceptualizing criminal thinking: a personal view. Criminal Behaviour and Mental Health, 16, 87-99.

Walters G.D. (1990). The Criminal Lifestyle. Patterns of Serious Criminal Conduct. Newbury Park-London-New Delhi: Sage Publications.

Walters G.D. (2002). Criminal belief systems: An integrated - interactive theory lifestyles. Westport, CT: Praeger.

Walters G.D. (2006b). The psychological Inventory of Criminal Thinking Styles (PICTS) professional manual. Allentown, Pensylwania: Center for Lifestyle Studies.

Walters G.D. (2006c). Lifestyle Theory: Past, Present and Future. New York: Nova Science Publisher.

Watts D.J., Strogatz S.H. (1998). Collective dynamics of 'small-world' networks. Nature, International Weekly Journal of Science, 393, 440-442.

Weber M. (2020). Gospodarka i społeczeństwo. Zarys socjologii rozumiejącej. Przeł. i wstępem opatrzyła D. Lachowska. Warszawa. 
Weiner B. (1979). A theory of motivation for some classroom experiences. Journal of Educational Psychology, 71, 3-25.

Weiner B. (1986). An Attributional Theory of Motivation and Emotion. New York: Springer Verlag.

Weiner B. (1995). Judgments of responsibility A foundation for a theory of social conduct. New York: Guilford.

Wilder D.A. (1993). The role of anxiety in facilitating stereotyping judgement of outgroup behavior (87-109). W: D.M. Mackie, D.L. Hamilon (eds.). Affect, cognition and stereotyping. Interactive process in group perception. San Diego: Academic Press.

Wojcieszek K.A. (2013). Optymalizacja profilaktyki problemów alkoholowych. Pedagogiczne implikacje grupowych interwencji krótkoterminowych. Kraków: Rubikon.

Wojciszke B. (2006). Człowiek wśród ludzi. Zarys psychologii społecznej. Warszawa: Scholar.

Wojciszke B. (2011). Psychologia społeczna. Warszawa: Scholar.

Wosińska W. (2004). Psychologia życia społecznego. Gdańsk: GWP.

Wódz J. (1973). Zjawiska patologii społecznej a sankcje społeczne i prawne. WrocławWarszawa-Kraków. Gdańsk: Ossolineum.

Wysocka E., Ostafińska-Molik B. (2014). Zaburzenia internalizacyjne i eksternalizacyjne a typ rodziny pochodzenia - analiza teoretyczna i wyniki badań. Resocjalizacja Polska, 8, 131-155.

Yochelson S., Samenow S. (1993). The Criminal Personality. Vol. 1: A Profile for Change. New York: Jason Aronson, Inc.

Zieleniewski J. (1982). Organizacja zespołów ludzkich. Wstęp do teorii organizacji i kierowania. Warszawa: PWN.

Ziemska M. (1973). Postawy rodzicielskie. Warszawa: Wiedza Powszechna.

Ziomek-Michalak K. (2005). System wartości osadzonych w świetle badań pilotażowych. Zamojskie Studia i Materiaty, VII, 1(16). 